\title{
MATERI CURRICULUM PRORAM PELATIHAN UMKM
}

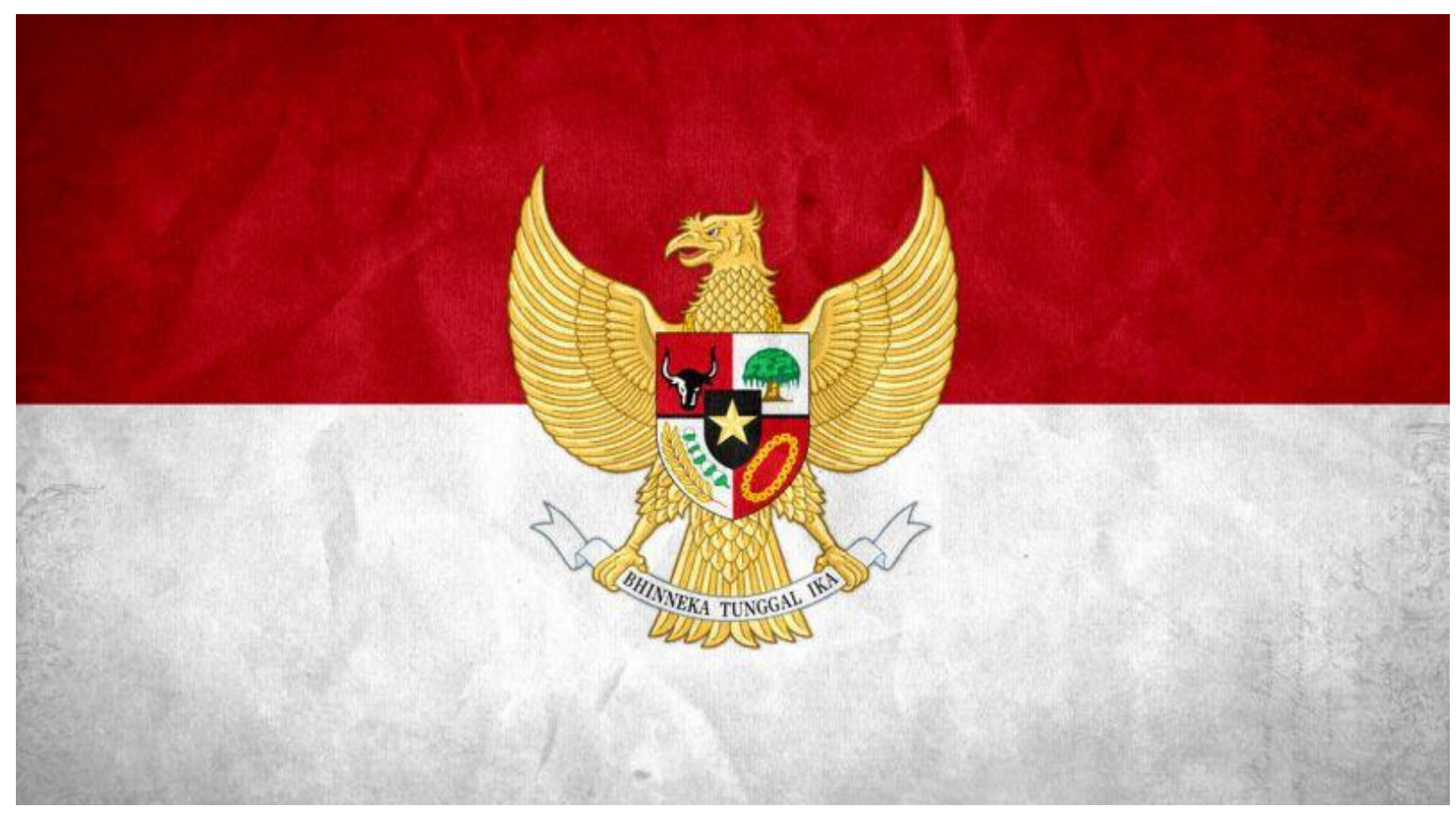




\section{MATERI CURRICULUM PRORAM PELATIHAN UMKM}

Disusun oleh

Tjahjo Ruruh Djatmiko, Ir.MM.MBA 
Modul I

1. Standar Kualitas

\section{Penjelasan Umum Modul}

\section{Modul Standar Kualitas}

\subsection{Pemahaman Umum Standar Kualitas}

\subsection{Manfaat Standar Kualitas}

\subsection{Kriteria Kualitas}

Output:

- Peserta sadar pentingnya memiliki standar kualitas

- Peserta memahami apa itu standar kualitas

- Peserta memahami kriteria dari standar kualitas

- Peserta memahami langkah-langkah umum menentukan standar kualitas

Estimasi durasi untuk mengerjakan secara mandiri $\quad$ : 1-4 jam

Dukungan yang dibutuhkan

o Pendampingan Mentor untuk penulisan Kriteria Standar Kualitas Produk/Jasa, setelah mencoba mengerjakan secara mandiri

- Membahas bersama UKM lain, Standar Kualitas dan Kriteria Kualitas masing-masing 


\section{Lembar Kerja Modul}

\section{Standar Kualitas}

Sebelum kita mulai, coba Anda tuliskan di kotak bawah ini, apa yang Anda bayangkan bila mendengar kata 'Standar Kualitas'

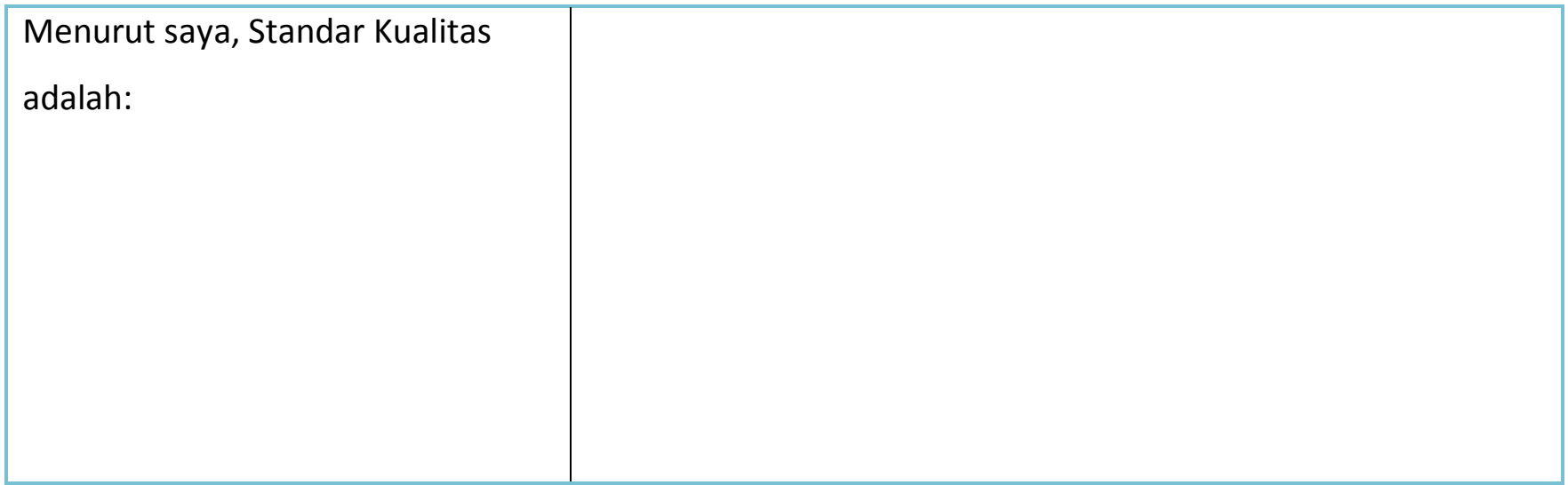

Setelah menulis jawaban Anda, silakan lanjut ke halaman berikutnya.

Menurut Standar Internasional (ISO 8402) suatu produk dapat dikatakan berkualitas apabila memenuhi kriteria - kriteria sebagai berikut:

- Sesuai dengan kebutuhan dan penggunaan

- Memuaskan keinginan pemakai

- Sesuai dengan persyaratan yang ditetapkan

- Sesuai dengan ketentuan hukum yang berlaku

- Ekonomis

Dalam Modul ini, kita juga akan belajar tentang bagaimana menentukan kriteria-kriteria kualitas untuk produk/jasa Anda.

Apa manfaatnya bagi Anda, bila Anda menetapkan Standar Kualitas?

Suatu usaha yang memiliki standar kualitas tentunya bisa mendapatkan manfaat sebagai berikut:

- Mencapai dan mempertahankan kualitas barang atau jasa yang dihasilkannya sehingga terus - menerus memenuhi kebutuhan konsumen.

- Memberikan keyakinan kepada pengelolanya sendiri, bahwa kualitas yang dikehendaki dicapai dan dipertahankan.

2 Kemendagri - sylabus - 2018 
- Memberikan kepercayaan kepada konsumen bahwa kualitas yang diinginkan akan dicapai dalam barang atau jasa yang diberikan.

- Sehingga, jelas bahwa manfaatnya adalah konsumen/pembeli/penikmat jasa Anda akan terus-menerus membeli/menggunakan produk atau jasa Anda dan berarti pemasukan yang berulang (dan semoga meningkat!)

Agar modul ini bisa efektif membantu Anda memahami dan mencoba mengembangkan Standar Kualitas produk/jasa, sebaiknya kita fokuskan pembahasan pada 1 produk/jasa yang Anda hasilkan.

Silakan tuliskan di bawah, apa Produk atau Jasa yang Anda akan fokuskan untuk kita bahas penetapan standar kualitasnya:

\begin{tabular}{|lr|}
\hline $\begin{array}{lr}\text { Produk / Jasa yang Saya } \\
\text { akan fokuskan untuk }\end{array}$ & \\
kembangkan Standar & \\
Kualitasnya adalah:
\end{tabular}

Baiklah, sekarang setiap kali kita membahas tentang Standar Kualitas, Anda harus fokus membayangkan tentang Produk/Jasa yang Anda tuliskan di atas ya.

Nah sekarang, coba sebutkan/bayangkan, situasi di mana Produk/Jasa Anda dinilai bagus atau konsumen sangat puas.

Atas alasan apa sajakah, mereka menilai Produk/Jasa Anda sebagai bagus atau memuaskan?

\begin{tabular}{|l|r|}
\hline Alasan utama konsumen & \\
saya menilai Produk/Jasa & \\
kami bagus atau & \\
memuaskan: & \\
&
\end{tabular}


Umumnya, Produk atau Jasa kita dinilai bagus/baik atau memuaskan adalah berdasarkan alasan-alasan berikut:

o Bahan baku yang baik

o Pengerjaan yang baik

o Desain yang baik

o Tahan lama

o Harga yang sesuai fungsi

o Harga yang sesuai kualitas

o Mudah mendapatkannya (konsumen tidak sulit menemukan dan memperolehnya)

- Cepat mendapatkannya (konsumen tidak butuh waktu lama untuk memperolehnya)

- Cara mendapatkannya menyenangkan (konsumen menikmati upaya untuk membeli, mendapatkan dan menikmati produk/jasa Anda)

Secara jujur, coba pilih dan beri tanda pada alasan-alasan di atas, yang membuat Produk/Jasa Anda dinilai baik atau memuaskan oleh konsumen Anda.

Nah, Standar Kualitas, adalah tentang menentukan alasan-alasan apa saja yang Produk/Jasa Anda akan selalu dinilai baik atau memuaskan konsumen Anda. Alasan-alasan tersebut, kita istilahkan sebagai 'Kriteria Kualitas'

Kriteria Standar Kualitas biasanya mencakup:

- Bahan Baku/Alat yang digunakan

- Proses Produksi/Langka Kerja

- Produk/Jasa akhir yang dinikmati konsumen

- Tenaga Kerja/Pembuatnya

Standar Kualitas yang baik adalah yang dengan mudah kita bisa 'mengukur'nya...contohnya:

- Bahan baku yang baik $\rightarrow$ bila makanan, misalnya tingkat kesegaran (tingkat kesegaran $\rightarrow$ ditangkap/dipanen kurang dari sekian jam, langsung diolah); bila kerajinan misalnya, kualitas dan asal kayu (tingkat kekeringan $\mathrm{x} \%$, merupakan kayu tersertifikasi, dsb); bila jasa, misalnya perlengkapan atau fasilitas yang digunakan adalah yang terbaru (produksi/dibeli tahun sekian), terawat (dirawat setiap $\mathrm{x}$ bulan sekali); tidak mengandung zat berbahaya, memenuhi standar keamanan/kesehatan tertentu, dsb

4 Kemendagri - sylabus - 2018 
o Pengerjaan yang baik $\rightarrow$ tentang proses pengerjaan, misalnya: dimasak oleh koki berpengalaman $\mathrm{X}$ tahun dan bersertifikat/memenangkan kompetisi $\mathrm{X}$, diolah oleh pengrajin berpengalaman dari Desa $\mathrm{Y}$, dipandu oleh tour guide/dive master tersertifikasi, mengikuti resep tradisional, sesuai dengan cara pengerjaan turun temurun sesuai budaya kampung $\mathrm{X}$.

o Desain yang baik $\rightarrow$ tentang kegunaan atau estetika, misalnya: mudah dipegang, mudah dikemas, warna yang terang, cocok untuk digunakan di situasi tertentu (basah, kering, dalam ruangan, luar ruangan, pagi, siang, malam), dsb.

o Tahan lama $\rightarrow$ tentang ketahanan produk, misalnya: tahan air/basah, tahan guncangan, tidak mudah retak dalam pemakaian normal, tidak berubah bentuk/warna/kondisi dalam temperature $\mathrm{X}$ derajat celcius sampai dengan $\mathrm{Y}$ derajat celcius, bisa dipakai hingga $\mathrm{X}$ kali, tidak perlu diganti hingga $\mathrm{X}$ bulan atau tahun, $\mathrm{dsb}$.

o Harga yang sesuai fungsi: tentang seberapa ekonomis produk Anda, misalnya: di bawah 100ribu, rusak kurang dari $\mathrm{X}$ tahun, reparasi gratis, dsb.

Nah, sekarang silakan Anda coba merumuskan Standar Kualitas untuk maksimal 3 Kriteria yang Anda sudah tuliskan sebelumnya:

\begin{tabular}{|l|l|}
\hline Kriteria & Standar Kualitas \\
\hline & \\
\hline & \\
\hline & \\
\hline & \\
\hline
\end{tabular}


Jika pada bagian ini, Anda merasa kesulitan, silakan berdiskusi dengan TIM Pendamping. Jika sudah selesai, apa yang Anda tulis pada bagian ini, adalah Standar Kualitas Produk atau Jasa Anda.

Baiklah, sekarang Anda sudah memahami apa itu Standar Kualitas dan Kriteria Kualitas, dan sudah berupaya membuat Standar Kualitas bagi Produk/Jasa Anda!

Tantangan yang Anda hadapi setelah ini adalah keberanian untuk menjaga Standar Kualitas Produk atau Jasa Anda agar selalu memenuhi Kriteria Kualitas di atas, dan semoga, meningkatkannya terus-menerus!

Selamat! Ini langkah awal Anda untuk bisa membuat UKM Anda berkualitas secara konsisten. Setelah mengerjakan Modul ini, Anda seharusnya sudah:

o memahami apa itu Standar Kualitas

o sadar Manfaat memiliki Standar Kualitas

o memahami Kriteria dari Standar Kualitas

o memahami langkah-langkah umum menentukan Standar Kualitas, dan

o mampu membuat Standar Kualitas Produk

Bila ada yang belum Anda pahami dan mohon tandai dengan ' $x$ 'di daftar di atas. Tuliskan di kotak bawah, hal-hal yang masih Anda anggap kurang jelas atau Anda ingin ketahui lebih lanjut:

Lalu hubungi TIM Pendamping terdekat.

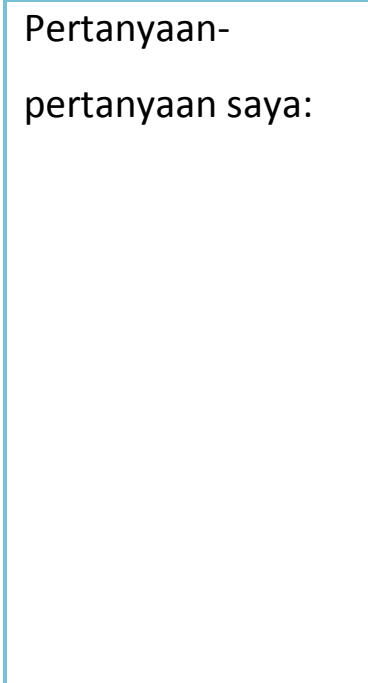

6 Kemendagri - sylabus - 2018 


\section{Modul I \\ 2. Standar Kualitas Produksi}

\section{Penjelasan Umum Modul}

2. Standar Proses Produksi/Langkah Kerja

2.1. Pemahaman Umum Standar Proses Produksi / Langkah Kerja

2.2. Manfaat Standar Proses Produksi / Langkah Kerja

2.3. Penyusunan Standar Proses Produksi / Langkah Kerja

Output:

- Peserta memahami apa itu Standar Proses Produksi / Langkah Kerja

- Peserta sadar pentingnya memiliki Standar Proses Produksi / Langkah Kerja

- Peserta memahami langkah-langkah umum menyusun Standar Proses Produksi / Langkah Kerja

Durasi untuk mengerjakan : $\quad 2-6$ jam

Dukungan yang dibutuhkan :

- Pendampingan Mentor untuk penulisan Standar Proses Produksi atau Langkah Kerja

- Membahas bersama UKM lain, Standar Proses Produksi atau Langkah Kerja 


\section{Lembar Kerja Modul}

\section{Standar Proses Produksi/Langkah Kerja}

Sebelum kita mulai, coba Anda tuliskan di kotak di bawah ini, 1 (satu) Produk atau Jasa yang Anda ingin jadikan pembahasan kita:

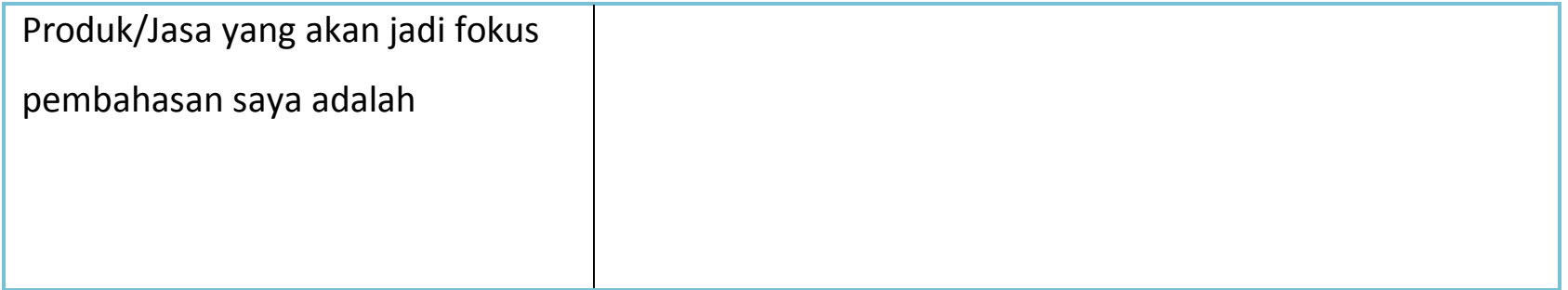

Baiklah, selama mengerjakan Modul ini, Anda harus fokus hanya pada Produk/Jasa yang telah Anda tulis di atas.

*Catatan:

Bila yang Anda tuliskan di atas adalah sebuah produk (ada benda/barang nya), maka silakan lanjutkan membaca dan mengerjakan panduan di halaman ini.

Bila yang Anda tuliskan di atas adalah sebuah jasa (tidak berupa benda, lebih berupa pengalaman, misalnya pengalaman wisata atau kegiatan tertentu), silakan lanjutkan ke halaman berikut.

Bisakah Anda menuliskan/menggambarkan di kotak di bawah, langkah-langkah atau hal-hal yang harus dilakukan untuk menciptakan/menghasilkan produk yang Anda telah tuliskan di atas. Mulai dari awal sekali, yaitu bagaimana Anda mendapatkan/memilih/membeli bahan baku untuk produk Anda, sampai ke bagian akhir, misalkan membungkus atau mengantarkan produk Anda.

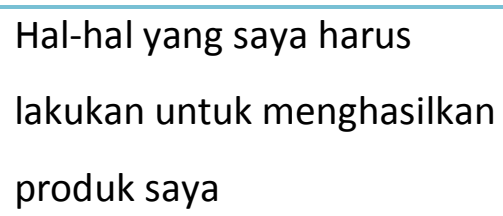


*Upayakan agar langkah-langkahnya berurutan, jika perlu, beri nomor urut dari awal hingga ke akhir. Lalu lanjutkan ke halaman berikutnya

Tuliskan di kotak di bawah ini, langkah-langkah kerja yang Anda harus lakukan agar konsumen bisa menikmati Jasa yang Anda tuliskan di atas. Mulai dari awal sekali, misalnya sejak konsumen menghubungi Anda untuk menikmati Jasa Anda, hingga konsumen mengakhiri pengalaman menikmati Jasa Anda:

\begin{tabular}{|l|l|}
\hline $\begin{array}{l}\text { Hal-hal yang saya harus } \\
\text { kerjakan agar Konsumen } \\
\text { bisa menikmati Jasa saya } \\
\text { adalah }\end{array}$ & Pada saat sebelum konsumen menikmati Jasa Anda: \\
& Pada saat (selama) konsumen menikmati Jasa Anda \\
& Setelah Konsumen menikmati Jasa Anda: \\
\hline
\end{tabular}

Selamat, Anda sudah mencoba menyusun Proses Produksi/Langkah Kerja.

Manfaat dari menuliskan Proses Produksi atau Langkah Kerja ini adalah antara lain:

- Anda jadi bisa lebih mudah mengajarkan kepada orang lain (menambah jumlah pekerja)

- Anda jadi bisa membuat standar apa saja yang harus dilakukan, dan apa saja yang dibutuhkan di setiap langkah

- Anda jadi bisa menilai bila seseorang lain melakukan Proses Produksi atau Langkah Kerja, apakah sudah sesuai dengan Standar yang Anda susun.

Sebisa mungkin, Proses Produksi / Langkah Kerja yang Anda susun adalah sedetil mungkin bahkan proses/langkah yang tidak selalu dilakukan. 
Saya berikan contoh:

\section{Proses Produksi/Membuat Mie Rebus Instan}

1. Beli Mie Rebus Instan Rasa X sejumlah 1 bungkus di warung terdekat.

2. (Opsional) Beli Telur Ayam sejumlah 1 butir.

3. (Opsional) Beli Bawang Merah 1 butir.

4. Panaskan 2.5 gelas air (sekitar $500 \mathrm{ml}$ ) hingga mendidih, dengan panci.

5. Sambil menunggu air mendidih, buka kemasan mie instan yang Anda sudah beli dan keluarkan mie beserta bumbunya.

6. (Opsional) Sambil menunggu air mendidih, kupas bawang merah dan iris tipis-tipis.

7. Ketika air sudah mendidih, kecilkan api kompor dan masukkan mie instan. Biarkan mie di dalam panci air mendidih selama 5 menit hingga melunak.

8. (Opsional) Setelah sekitar 2.5 menit, pecahkan telur ayam dan masukkan kuning dan putih telur dan irisan bawang merah ke dalam panci.

9. Sambil menunggu mie selesai direbus, buka kemasan bumbu mie instan dan masukkan ke dalam mangkuk penyajian. Aduk bumbu mie instan dengan menggunakan garpu.

10. Setelah mie direbus selama 5 menit dengan api kecil, tuangkan isi panci ke mangkuk saji. Perhatikan porsi kuah tidak melampaui ukuran mangkuk saji.

11. Sajikan mie rebus di mangkuk saji dengan sendok dan garpu untuk menikmatinya. Langkah Kerja Memotong (Mencukur) Rambut

1. Ketika tamu datang, tanyakan kebutuhan mereka (misalnya: ingin dipotong seperti apa).

2. (Opsional) Berikan mereka contoh potongan rambut, minta tamu memilih potongan seperti apa yang paling sesuai/mendekati kebutuhan/keinginan mereka.

3. Sampaikan biaya yang harus mereka bayar untuk jasa potongan rambut yang mereka minta.

4. Pastikan mereka sudah menyetujui biaya yang diajukan (anggukan atau bahkan tanda tangan lembar konfirmasi).

5. (Opsional) Persilakan tamu untuk menunggu di ruang tunggu sambil menunggu giliran. 
6. Siapkan perlengkapan mencukur: kursi, handuk leher, kain penutup/pelindung badan untuk cegah rambut masuk ke pakaian, 1 penjepit handuk, 1 penjepit kain penutup/pelindung, 1 set gunting (+pisau cukur), dan alat-alat potong rambut lain

7. Persilakan tamu duduk di kursi potong rambut.

8. Pastikan tamu duduk dengan nyaman dan posisi kepala tamu/konsumen tidak lebih tinggi dari dagu Anda.

9. Pasangkan handuk di lehar tamu, dengan menggunakan tangan kanan Anda.

10. Pastikan handuk sudah menutupi bagian kerah pakaian tamu.

11. Jepit handuk di bagian belakang leher. Pastikan tidak ada celah namun juga jangan sampai mencekik tamu. Tanyakan tamu apakah sudah nyaman dengan kondisi duduk dan handuk.

12. Pasangkan kain penutup/pelindung badan dengan tangan kanan. Pastikan menutupi sebagian besar tubuh dan pakaian hingga ke batas atas (kerah pakaian) dan batas bawah melewati lutut tamu.

13. Jepit kain penutup/pelindung badan di bagian belakang. Pastikan tidak terlalu mencekik tamu. Tanyakan tamu apakah sudah nyaman dengan kondisi kain penutup.

14. Mulai lakukan kegiatan pemotongan rambut sesuai dengan gaya/jenis potongan rambut yang diinginkan.

15. Usahakan proses pemotongan rambut kurang dari 30 menit. Bila mendekati 30 menit dan sepertinya tidak akan selesai sebelum 30 menit, sampaikan kepada tamu bahwa proses pemotongan masih akan berlangsung sekitar sekian menit lagi (beri perkiraan waktu terbaik Anda).

16. Pada bagian-bagian tertentu pemotongan (poni, tepian rambut dan bagian tengkuk/belakang), tunjukkan hasil sementara dengan menggunakan cermin portabel kepada tamu dan pastikan mereka menyetujui/menyukai potongannya.

17. Ketika selesai proses pemotongan, pastikan menunjukkan hasil kepada tamu dengan cermin portable dan mendapatkan persetujuan mereka.

18. Bersihkan sisa potongan rambut yang menempel di kepala, leher dan wajah tamu dengan menggunakan sikat pembersih rambut. 
19. Bersihkan sisa potongan rambut di kain penutup/pelindung badan dengan menggunakan sikat pembersih rambut.

20. Buka penjepit kain penutup/pelindung badan secara perlahan dengan tangan kiri, tahan ujung kain dengan tangan kanan

21. Letakkan penjepit kain penutup/pelindung badan di kotak perlengkapan memotong rambut.

22. Secara perlahan, angkat kain penutup/pelindung badan secara perlahan pastikan tidak ada potongan rambut sisa yang dapat terjatuh ke pakaian tamu.

23. Lipat kain penutup/pelindung badan dengan sisi bersih di bagian luar, letakkan di tempat kain penutup/pelindung badan yang akan dicuci.

24. Copot secara perlahan penjepit handuk leher, dengan tangan kiri, sementara tangan kanan Anda menahan ujung-ujung handuk.

25. Letakkan penjepit handuk leher di kotak perlengkapan memotong rambut.

26. Angkat handuk leher dengan perlahan, pastikan tidak ada potongan rambut yang terjatuh ke pakaian tamu.

27. Lipat handuk leher dengan sisi bersih di bagian luar, letakkan di tempat handuk leher yang akan dicuci.

28. Bersihkan pakaian dan leher tamu dengan sikat halus pembersih potongan rambut.

29. Sampaikan bahwa proses potong rambut sudah selesai dan persilakan tamu untuk menyelesaikan pembayaran di kasir.

30. Sampaikan ke kasir mengenai biaya potong rambut tamu dan pastikan tamu membayar sesuai dengan biaya yang disepakati.

31. Setelah tamu membayar, ucapkan terima kasih.

32. (Opsional) Antar tamu hingga keluar.

33. Bersihkan kursi potong dan area potong yang sudah digunakan.

34. Bersihkan perlengkapan potong rambut yang sudah digunakan.

Nah apakah Anda sudah berupaya menuliskan Proses Produksi atau Langkah Kerja sedetil yang dicontohkan? 
Jika belum, silakan tuliskan kembali Proses Produksi atau Langkah Kerja untuk Produk atau Jasa Anda di kotak di bawah:

Proses Produksi/Langkah Kerja

*Silakan gunakan kertas terpisah bila ruang untuk menuliskannya kurang untuk Proses Produksi atau Langkah Kerja Anda. Jangan lupa melampirkan kertas terpisah/tambahan tersebut di Modul ini.

Beberapa tips menuliskan Proses Produksi atau Langkah Kerja yang baik:

- Setiap langkah harus jelas, apakah dikerjakan setelah atau bersamaan dengan langkah sebelumnya

- Sebisa mungkin, tuliskan dengan detil, apa yang harus terjadi/dilakukan di setiap proses/langkah

o Sebisa mungkin, beri keterangan tentang berapa lama waktu di setiap proses/langkah

- Sebisa mungkin, beri keterangan apa yang menjadi 'tanda' bahwa langkah tersebut sudah selesai dan harus berlanjut ke langkah berikutnya

- Coba berikan Proses Produksi atau Langkah Kerja yang Anda sudah tuliskan, kepada orang lain yang juga mengerti tentang proses produksi Produk atau langkah kerja Jasa Anda. Orang tersebut bisa karywawan Anda yang paling ahli atau orang yang mengajari Anda melakukan proses Produksi atau keterampilan melakukan jasa Anda. Minta mereka untuk memberi komentar: apa yang sudah jelas dan apa yang belum jelas atau terlewatkan

Silakan buat daftar siapa saja orang atau orang-orang yang bisa Anda tunjukkan Proses Produksi / Langkah Kerja yang telah Anda tuliskan:

13 Kemendagri - sylabus - 2018 
Daftar nama orang yang bisa saya mintakan pendapat:

Kapan saya akan mintakan pendapat mereka (rata-rata orang butuh 20-30 menit untuk membaca Proses Produksi atau Langkah Kerja, bila jumlahnya lebih dari 15 langkah)

Setelah Anda meminta pendapat mereka, bila ada perubahan, silakan lakukan perubahan yang menurut Anda baik atau dibutuhkan.

Tuliskan kembali seluruh Proses Produksi atau Langkah Kegiatan yang sudah disesuaikan dengan saran/pendapat orang-orang di atas.

Beri judul: Standar Proses Produksi/Langkah Kerja [Nama Produk/Jasa] dari [Nama Usaha Anda]

Jangan lupa beri tanggal kapan Anda menuliskannya

Sekarang, tantangannya adalah:

- Anda harus memastikan semua orang yang terlibat produksi mengetahui dan mengikuti Standar Proses Produksi/Langkah Kerja tersebut

- Anda harus mengajarkan semua orang produksi atau yang melakukan jasa di UKM Anda agar bisa mengikuti Standar Proses Produksi/Langkah Kerja tersebut

Selamat, Anda sudah memiliki Standar Proses Produksi/Langkah Kerja untuk Produk atau Jasa Anda! Semoga dengan Standar ini, Kualitas Produk Anda akan selalu konsisten/bertahan sama baiknya, kapanpun.

Setelah mengerjakan Modul ini, Anda seharusnya sudah:

O memahami apa itu Proses Produksi atau Langkah Kerja

o sadar Manfaat memiliki Proses Produksi atau Langkah Kerja yang tertulis

o memahami langkah-langkah umum menuliskan Proses Prosuksi atau Langkah Kerja

- mampu menuliskan Proses Produksi atau Langkah Kerja untuk 1 produk/jasa Anda 
O dapat menggunakan Proses Produksi atau Langkah Kerja untuk 1 produk/jasa Anda tersebut sebagai Standar Proses Produksi atau Langkah Kerja

Bila ada yang belum anda pahami dan, mohon tandai dengan ' $x$ 'di daftar di atas. Tuliskan di kotak bawah, hal-hal yang masih Anda anggap kurang jelas atau Anda ingin ketahui lebih lanjut:

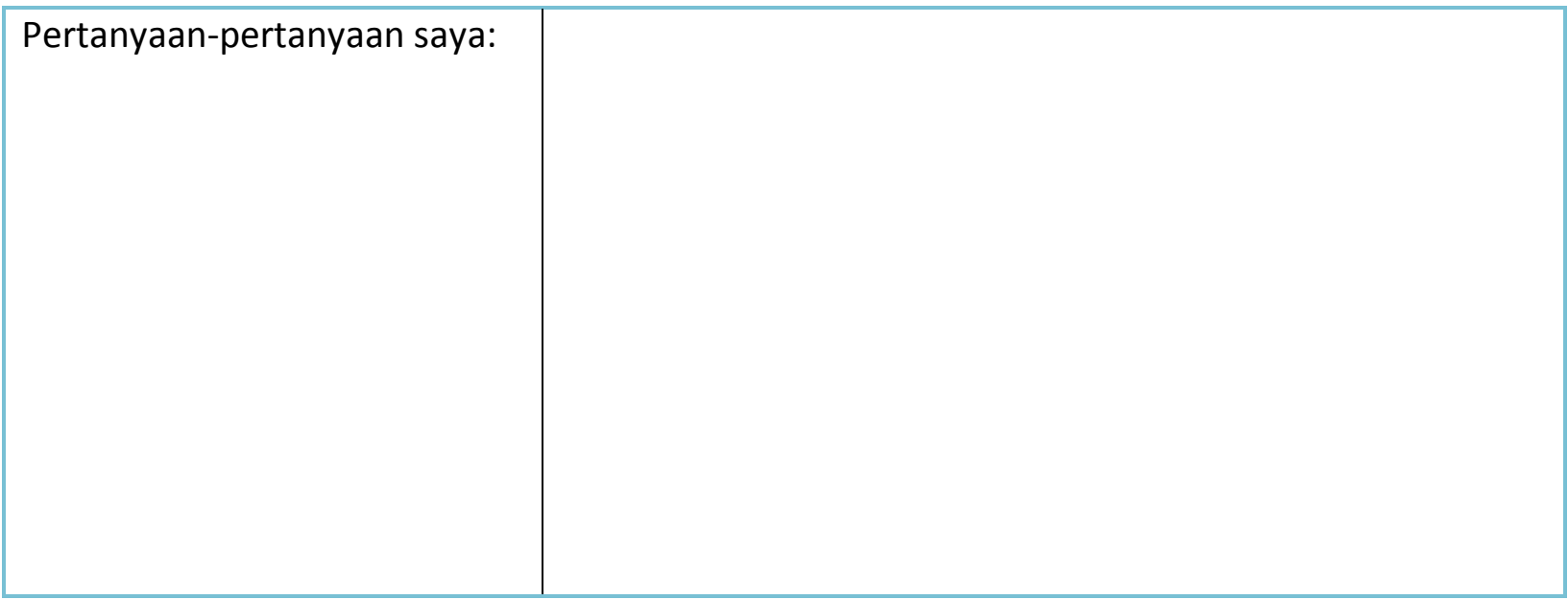

Lalu hubungi TIM Pendamping terdekat.

Anda siap untuk beranjak ke Modul berikutnya. 


\section{Modul I}

\section{Standar Bahan Baku / Alat Kerja}

\section{Penjelasan Umum Modul}

\section{Standar Bahan Baku / Alat Kerja}

\subsection{Pemahaman Umum Standar Bahan Baku / Alat Kerja}

\subsection{Manfaat Menuliskan Standar Bahan Baku / Alat Kerja}

\subsection{Penyusunan Standar Bahan Baku / Alat Kerja}

Output:

- Peserta memahami apa itu Standar Bahan Baku / Alat Kerja

- Peserta sadar pentingnya memiliki Standar Bahan Baku / Alat Kerja yang tertulis

- Peserta memahami langkah-langkah umum menyusun Standar Bahan Baku / Alat Kerja

Durasi untuk mengerjakan : 2-4 jam

Dukungan yang dibutuhkan :

- Pendampingan Mentor untuk penulisan Standar Bahan Baku atau Alat Kerja

- Membahas bersama UKM lain, Standar Bahan Baku atau Alat Kerja 


\section{Lembar Kerja Modul}

\section{Standar Bahan Baku / Alat Kerja}

Sebelum kita mulai, coba Anda tuliskan di kotak di bawah ini, 1 (satu) Produk atau Jasa yang Anda ingin jadikan pembahasan kita:

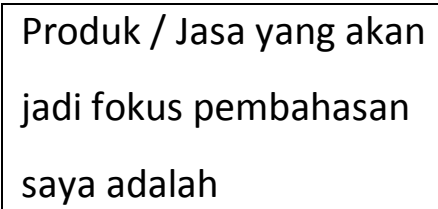

Selama mengerjakan Modul ini, Anda sebaiknya fokus hanya pada Produk / Jasa yang telah Anda tulis di atas.

*Catatan: Bila yang Anda tuliskan di atas adalah sebuah produk (ada benda/barang nya), maka silakan lanjutkan membaca dan mengerjakan panduan di halaman ini. Bila yang Anda tuliskan di atas adalah sebuah jasa (tidak berupa benda, lebih berupa pengalaman, misalnya pengalaman wisata atau kegiatan tertentu), silakan lanjutkan ke halaman berikut.

Apakah Anda sudah pernah membuat kue? Ketika Anda membuat kue, biasanya diawali dengan membaca buku resep. Bagian awal dari buku resep umumnya adalah daftar bahanbahan yang dibutuhkan untuk membuat kue tersebut.

Adanya daftar tersebut, membantu kita untuk mempersiapkan apa saja yang perlu ada, sebelum kita membuat kue tersebut.

Hal-hal tersebut adalah 'bahan baku' untuk membuat kue.

Sama situasinya dengan ketika membaca panduan untuk menyelam. Biasanya, bagian awal dari panduan tersebut akan mencantumkan perlengkapan yang dibutuhkan agar kegiatan menyelam dapat berjalan lancar dan aman. Perlengkapan tersebut adalah 'alat kerja' untuk seorang yang akan menyelam.

Baiklah, seperti contoh membuat kue, ketika kita membuat sesuatu, pasti ada yang namanya 'Bahan Baku' atau 'Bahan Dasar'. Pengertian Bahan Baku adalah bahan yang digunakan 17 Kemendagri - sylabus - 2018 
dalam membuat produk di mana bahan tersebut secara menyeluruh tampak pada produk jadinya atau merupakan bagian terbesar dari bentuk barang.

Jadi singkatnya, Bahan Baku adalah bahan-bahan yang dibutuhkan untuk membuat produk Anda. Contohnya, membuat sebuah kue membutuhkan bahan baku sebagai berikut:

- Tepung Terigu

- Telur

- Susu

Tanpa Tepung Terigu, Telur, Garam dan Susu, kue tersebut tidak mungkin jadi kue yang kita ingin buat.

Sedangkan Alat Kerja berarti semua peralatan / perlengkapan yang kita butuhkan untuk menghasilkan suatu produk atau melakukan suatu kegiatan. Tanpa peralatan / perlengkapan tersebut, kita tidak akan bisa menghasilkan produk tersebut atau melakukan kegiatan tersebut.

Bila Anda adalah penyelam, Anda tidak akan bisa menyelam tanpa perlengkapan berikut:

- masker selam

- pakaian selam

- tangki oksigen

- $\quad$ fin

- regulator oksigen $1 \& 2$

- ikat pinggang pemberat

- tompi BCD (pengatur buoyancy)

- pengukur kedalaman dan sisa oksigen

Tanpa alat-alat di atas, kegiatan menyelam tidak mungkin dilakukan atau akan membahayakan diri.

Nah sekarang, ingat kembali produk / jasa yang Anda tuliskan di halaman awal. Apa saja Bahan Baku / Alat Kerja yang dibutuhkan untuk hasilkan produk tersebut atau untuk lakukan kegiatan jasa tersebut? Apabila Anda UKM Jasa, cukup tuliskan peralatan / perlengkapan kerja yang dibutuhkan untuk lakukan / berikan layanan jasa tersebut. 


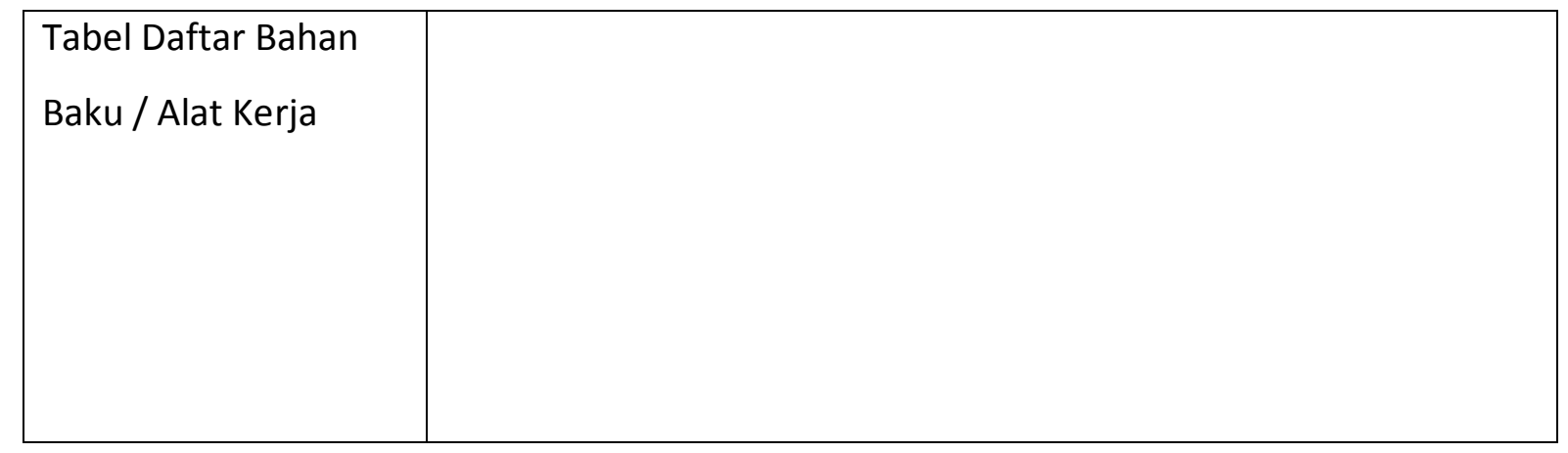

Sudah terisi dengan lengkap? Jika Anda tidak yakin, silakan diskusikan daftar tersebut dengan orang-orang yang juga memproduksi Barang atau melakukan kegiatan jasa yang sama!

Baiklah. Anda sudah berhasil menuliskan daftar Bahan Baku atau Alat Kerja Anda!

Semakin lengkap daftar Bahan Baku atau Alat Kerja Anda, semakin baik. Artinya Anda betulbetul mengetahui semua Bahan Baku atau Alat Kerja yang dibutuhkan sebelum Anda menghasilkan sebuah Produk atau melakukan suatu kegiatan Jasa.

Selalu pastikan, setiap kali Anda akan memproduksi Produk Anda atau melakukan kegiatan Jasa Anda, semua Bahan Baku atau Alat Kerja tersebut sudah tersedia.

Berikutnya, kita akan coba membuat Standar Bahan Baku atau Alat Kerja.

Dari daftar yang sudah Anda tuliskan, coba membuat rincian tentang satuan/jumlah Bahan Baku atau kondisi dan jenis Alat Kerja yang dibutuhkan.

Jika Anda UKM Produk, gunakan tabel berikut. Jika Anda UKM Jasa, gunakan tabel pada halaman berikut:

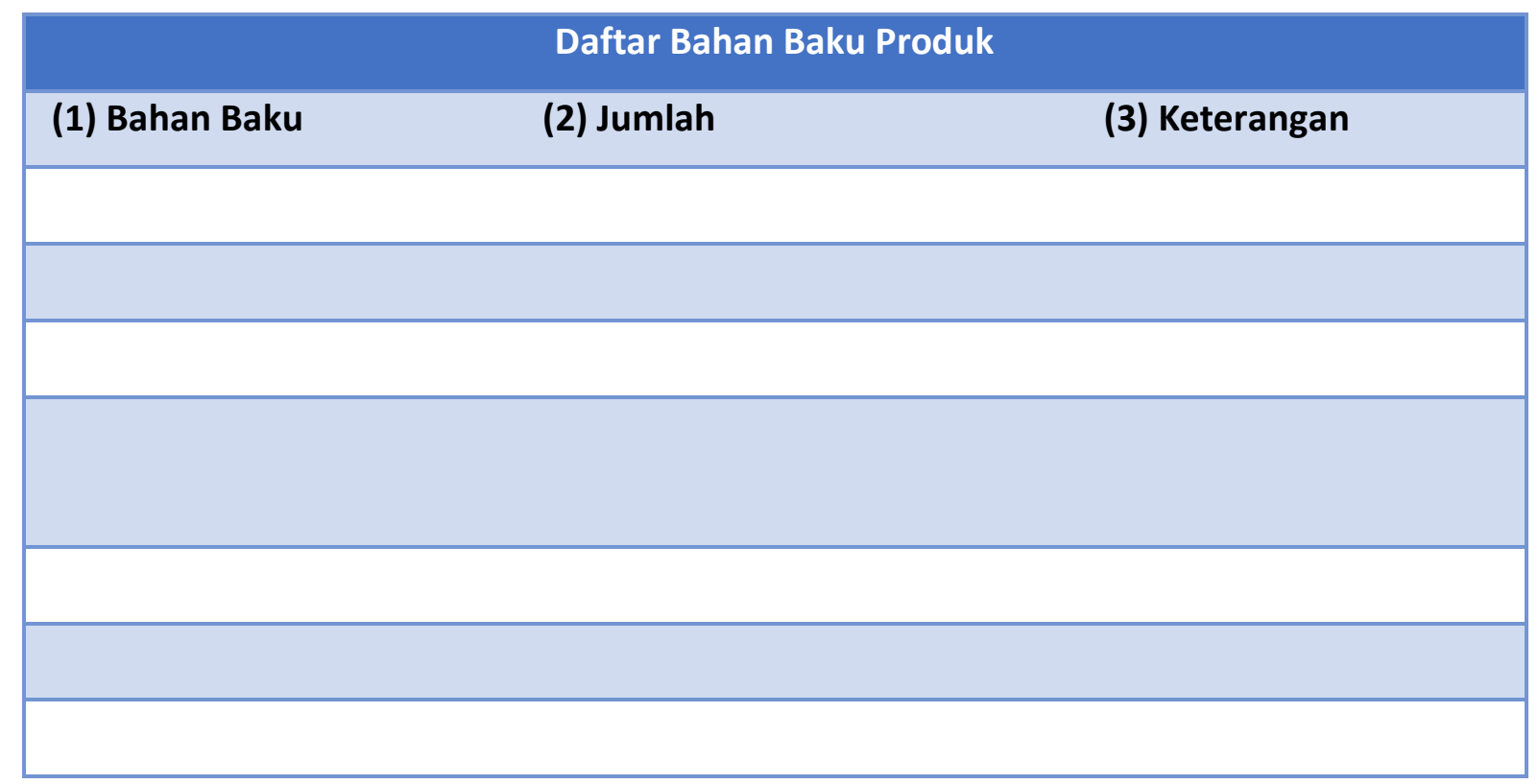


Pada kolom (1) Bahan Baku, tuliskan ulang daftar Bahan Baku yang sudah Anda tuliskan sebelumnya. Bila jumlah baris kurang, silakan gunakan kertas terpisah.

Pada kolom (2) Jumlah, tuliskan berapa banyak bahan baku yang dibutuhkan untuk menghasilkan sejumlah tertentu Produk (misalnya 3 butir telur untuk 1 loyang kue, $1 / 2 \mathrm{~kg}$ tepung untuk 1 loyang kue, dst).

Pada kolom (3) Keterangan, tuliskan informasi tambahan yang membantu Anda memilih/menentukan Bahan Baku yang terbaik atau kondisi minimal bahan baku. Misalnya, tepung merk $X$ atau telur ayam kampong atau susu yang baru diperah 24 jam yang lalu atau garam dari Madura dibeli di toko Y.

Jika sudah Anda lengkapi daftarnya, silakan lanjutkan ke halaman selanjutnya. Karena ketika Anda membuat suatu produk, pasti Anda juga membutuhkan Alat Kerja tertentu.

\begin{tabular}{|l|l|}
\hline Daftar Alat Kerja & (3) Keterangan \\
\hline (1) Spesifikasi Kerja & (2) \\
\hline & \\
\hline
\end{tabular}


Pada kolom (1) Alat Kerja, tuliskan ulang daftar Alat Kerja yang sudah Anda tuliskan sebelumnya. Bila jumlah baris kurang, silakan gunakan kertas terpisah.

Pada kolom (2) Spesifikasi, tuliskan spesifikasi teknis atau merk atau model yang Anda gunakan. Misalnya tabung oksigen ukuran $\mathrm{X}$ merk $\mathrm{Y}$ atau masker selam merk $\mathrm{Z}$ warna hitam atau panci diameter $\mathrm{X} \mathrm{cm}$ atau kompor gas merk $\mathrm{Z}$.

Pada kolom (3) Keterangan, tuliskan informasi tambahan yang membantu Anda memilih/menentukan kondisi terbaik suatu Alat Kerja atau kondisi minimum yang masih bisa digunakan. Misalnya: maksimal sudah digunakan $\mathrm{X}$ kali, masker tidak buram, panci dalam keadaan bersih, nyala api kompor berwarna kebiruan, dan sebagainya.

Jika sudah Anda lengkapi daftarnya, silakan lanjutkan ke halaman 23.

Selamat, Anda sudah berhasil menuliskan Standar Bahan Baku / Alat Kerja yang dibutuhkan oleh UKM Anda untuk menghasilkan Produk / Jasa tertentu!

Apa manfaatnya Anda sudah menuliskan Standar Bahan Baku / Alat Kerja ini?

1. Anda bisa memastikan kesiapan Anda untuk berproduksi/melakukan kegiatan jasa

2. Anda bisa menghitung berapa biaya yang dibutuhkan untuk menghasilkan sejumlah tertentu produk atau melakukan kagiatan jasa tertentu

3. Anda bisa mengajarkan kepada orang lain, tentang Bahan Baku / Alat Kerja yang dibutuhkan untuk menghasilkan sejumlah tertentu produk atau melakukan kegiatan jasa Anda

Jika pada bagian ini, Anda merasa kesulitan, silakan berdiskusi dengan TIM Pendamping. Jika sudah selesai, apa yang Anda tulis pada bagian ini, adalah Standar Bahan Baku atau Alat Kerja Anda.

Baiklah, sekarang Anda sudah memahami apa itu Standar Bahan Baku dan Alat Kerja bagi Produk/Jasa Anda!

Tantangan yang Anda hadapi setelah ini adalah keberanian dan ketekunan untuk menjaga Standar Bahan Baku atau Alat Kerja Anda agar selalu sama jumlah dan kondisinya.

Selamat! Ini langkah tambahan agar UKM Anda memiliki kualitas yang baik dan konsisten. 
Setelah mengerjakan Modul ini, Anda seharusnya sudah:

- memahami apa itu Standar Bahan Baku / Alat Kerja

- sadar manfaat memiliki Standar Bahan Baku / Alat Kerja

- memahami langkah-langkah menuliskan Standar Bahan Baku / Alat Kerja, dan

○ menuliskan Standar Bahan Baku / Alat Kerja

Bila ada yang belum anda pahami dan, mohon tandai dengan ' $x$ 'di daftar di atas. Tuliskan di kotak bawah, hal-hal yang masih Anda anggap kurang jelas atau Anda ingin ketahui lebih lanjut:

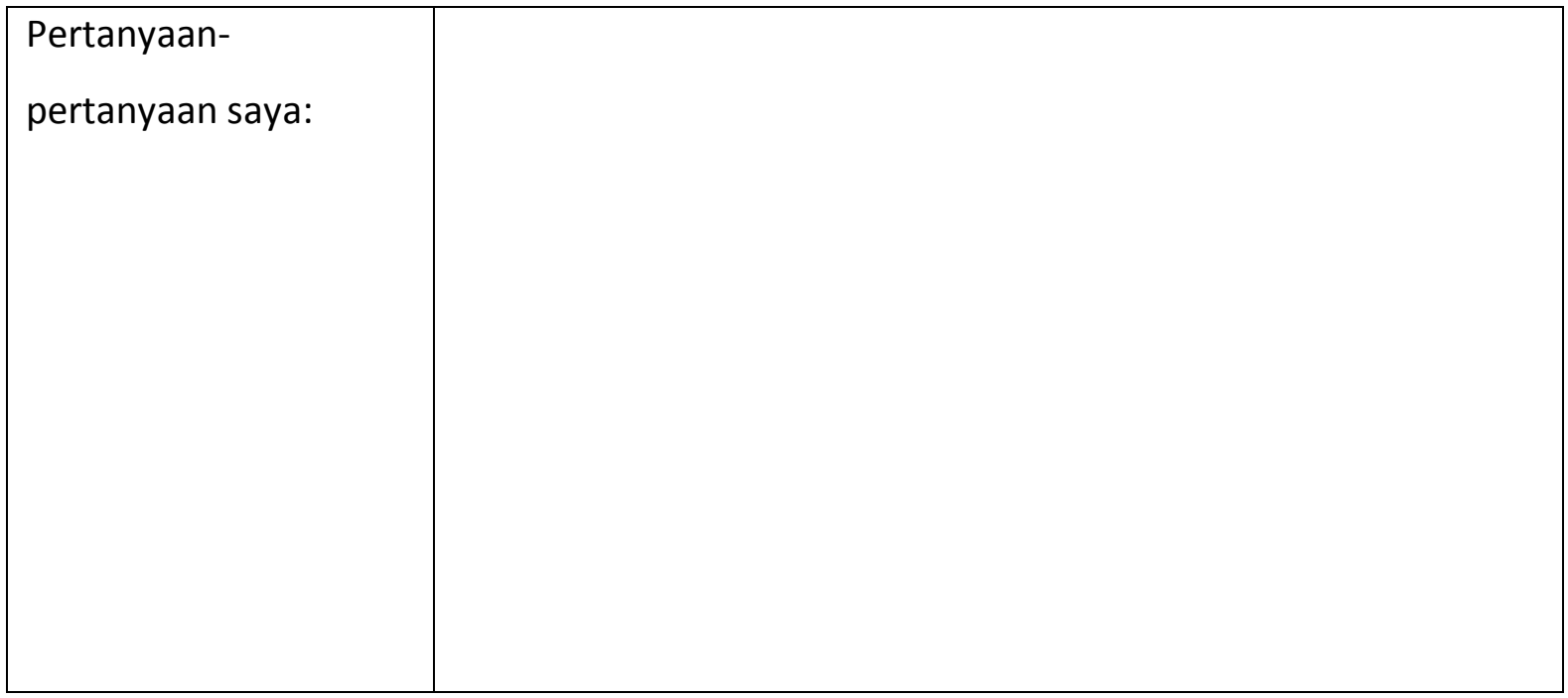

Lalu hubungi TIM Pendamping terdekat.

Anda siap untuk melanjutkan ke Modul selanjutnya! 


\section{Modul I}

\section{Pengurusan Izin Usaha}

\section{Penjelasan Umum Modul Pengurusan Izin Usaha}

Dalam Modul ini kami akan membahas mengenai pengurusan perizinan badan usaha di Indonesia.

Output:

- Peserta memahami jenis-jenis perizinan yang akan dipilih

- Peserta memahami proses perizinan usaha

- Peserta memahami pihak yang dapat membantu memproses perizinannya

Estimasi durasi untuk mengerjakan secara mandiri : 1-2 jam

Dukungan yang dibutuhkan

- Pendampingan pemerintah daerah setempat yang menangani perizinan usaha untuk membantu melakukan pengurusan perizinan

- Membahas bersama UKM lain yang sejenis sektor usahanya perihal proses perizinan yang dipilih oleh mereka

4. Modul Mengenai Pengurusan Izin Usaha

4.1 Tahap Pengurusan Izin Usaha

4.2 Studi Kasus 


\subsection{Tahap Pengurusan Izin Usaha}

\section{Surat Keterangan Domisili Usaha (SKDU)}

Dalam membuat sebuah Surat Keterangan Domisili Usaha setiap pelaku usaha wajib mempersiapkan beberapa dokumen :

1. Kartu Tanda Penduduk (KTP) pemilik/pendiri Badan Usaha UKM (asli dan fotokopi)

2. Kartu Keluarga (KK) pemilik/pendiri (asli dan fotokopi)

3. Akta Pendirian Badan Usaha dari Notaris (fotokopi)

4. Surat Pernyataan Tidak Keberatan dari tetangga (ditanda tangani minimal 4 orang warga yang bertetangga dengan tempat usaha Anda, dilampiri fotokopi KTP masing-masing)

5. Surat Perjanjian Sewa-Menyewa tempat usaha bermaterai (fotokopi), jika Anda menyewa tempat usaha Anda

6. Surat bukti kepemilikan tanah tempat usaha seperti Surat Tanah/Akta Jual Beli/Girik jika tempat usaha Anda milik Anda sendiri

7. Surat Kuasa jika pengurusan dikuasakan ke orang lain.

8. Dokumen lain yang sekiranya diperlukan, bisa ditanyakan ke Kantor Kelurahan tempat Kegiatan Usaha beroperasi.

Prosedur yang perlu dilakukan untuk mendapakan izin SKDU dapat dilakukan di Kelurahan/Kantor Kepala Desa setempat, berikut ialah proses pengurusannya:

1. Tindakan yang pertama kali perlu anda lakukan adalah untuk meminta surat pengantar dari RT dan RW setempat yang menyatakan bahwa kegiatan usaha yang anda buat benar-benar ada di lingkungan tersebut.

2. Setelah memiliki surat pengantar RT dan RW serta berkas persyaratan yang telah disiapkan, Anda kemudian datang ke Kantor Kelurahan atau Kantor Kepala Desa. Di sana Anda bisa meminta formulir permohonan SKDU ke petugas kelurahan/desa yang kemudian dapat Anda isi dengan benar dan lengkap. Setelah syarat-syarat terpenuhi anda dapat mengungu keperluaan SKDU untuk dikeluarkan dari pihak Kelurahan/Desa. Di beberapa daerah 
syarat dari dikeluarkan sebuah SKDU adalah pengurusan hingga ke kecamatan untuk meminta pengesahan dari Camat.

\section{Nomor Pokok Wajib Pajak (NPWP)}

Dalam membuat sebuah Nomor Pokok Wajib Pajak setiap pelaku usaha wajib mempersiapkan beberapa dokumen :

1. fotokopi Akta Pendirian atau dokumen pendirian dan perubahan bagi Wajib Pajak badan dalam negeri atau surat keterangan penunjukan dari kantor pusat bagi bentuk usaha tetap;

2. fotokopi Kartu Nomor Pokok Wajib Pajak salah satu pengurus, atau fotokopi paspor dan surat keterangan tempat tinggal dari Pejabat Pemerintah Daerah sekurangkurangnya Lurah atau Kepala Desa; dan

3. fotokopi dokumen izin usaha dan/atau kegiatan yang diterbitkan oleh instansi yang berwenang atau surat keterangan tempat kegiatan usaha dari Pejabat Pemerintah Daerah sekurang-kurangnya Lurah atau Kepala Desa atau lembar tagihan listrik dari Perusahaan Listrik/bukti pembayaran listrik.

Prosedur yang perlu dilakukan untuk mendapakan NPWP dapat dilakukan di Kantor Pelayanan Pajak setempat atau melalui pendaftaran secara online di situs ereg.pajak.go.id. Berikut ialah prosedur pendaftaran online:

1. Di laman Dirjen Pajak tersebut, pilih menu sistem e-Registration.

2. Jika Anda belum pernah mendaftarkan diri, silakan mendaftar terlebih dahulu untuk mendapatkan akun dengan mengklik "daftar". Isilah data pendaftaran pengguna dengan benar seperti nama, alamat email, kata sandi (password), dan lainnya. Setelah semua terisi, klik "Save".

3. Melakukan aktivasi akun yang telah anda daftarkan, Cara mengaktivasi akun Anda adalah dengan membuka kotak masuk (inbox) dari email yang Anda gunakan untuk mendaftar tadi, kemudian buka email yang masuk dari Dirjen Pajak. Ikuti petunjuk yang ada di dalam email tersebut untuk melakukan aktivasi.

4. Setelah proses aktivasi berhasil dilakukan, selanjutnya Anda harus login ke sistem e-Registration dengan memasukkan email dan password akun yang telah Anda buat. Atau Anda bisa mengklik tautan yang terdapat di dalam email aktivasi kedua 
dari Dirjen Pajak. Setelah login, Anda akan dibawa ke halaman Registrasi Data WP untuk memulai proses pembuatan NPWP. Silakan mengisi semua data dengan benar pada formulir yang tersedia. Ikuti semua tahapannya secara teliti. Bila data yang diisi benar, akan muncul surat keterangan terdaftar sementara.

5. Setelah semua data pada formulir pendaftaran terisi lengkap, pilih tombol daftar untuk mengirim Formulir Registrasi Wajib Pajak secara elektronik ke Kantor Pelayanan Pajak tempat Wajib Pajak terdaftar.

6. Selanjutnya Anda harus mencetak dokumen berikut seperti yang tampak pada layar komputer:

a. Formulir Registrasi Wajib Pajak

b. Surat Keterangan Terdaftar Sementara

7. Setelah Formulir Registrasi Wajib Pajak dicetak, silakan ditandatangani, kemudian sertakan berkas dokumen persyaratan yang telah disiapkan sebelumnya.

8. Setelah berkas kelengkapannya siap, Anda harus mengirimkan Formulir Registrasi Wajib Pajak, Surat Keterangan Terdaftar Sementara yang sudah ditandatangani, beserta dokumen lainnya ke Kantor Pelayanan Pajak (KPP) tempat badan/perusahaan Anda sebagai Wajib Pajak terdaftar. Berkas tersebut dapat diserahkan langsung ke KPP atau melalui Pos Tercatat. Pengiriman dokumen ini harus dilakukan paling lambat 14 hari setelah formulir terkirim.

9. Jika Anda tidak ingin repot-repot menyerahkan atau mengirimkan berkas secara langsung atau melalui pos ke KPP, Anda dapat memindai (scan) dokumen Anda dan mengunggahnya dalam bentuk digital (soft file) melalui aplikasi e-Registration tadi.

10. Cek status dan tunggu kiriman kartu NPWP kepada domisili anda.

\section{Surat Izin Usaha Perdagangan (SIUP)}

Dalam membuat sebuah Surat Izin Usaha Perdagangan setiap pelaku usaha wajib mempersiapkan beberapa dokumen sesuai bentuk badan Usahanya.

- Untuk Perseroan Terbatas (PT)

- Fotokopi Kartu Tanda Penduduk (KTP) Seluruh Pendiri 
- Fotokopi Kartu Keluarga (KK) Direktur Utama

- Fotokopi NPWP Seluruh Pendiri

- Surat Keterangan Domisili Usaha atau SITU

- Fotokopi Akta Pendirian PT yang disahkan oleh Menteri Hukum dan HAM.

- Fotokopi Surat Keputusan Pengesahan Badan Hukum dari Menteri Hukum dan HAM

- Surat Izin Gangguan (HO) bila melakukan kegiatan usaha yang dalam menjalankan kegiatan usahanya

- Izin Prinsip bila merupakan Perusahaan Modal Asing yang membuat Perseroan Terbatas di Indonesia

- Neraca perusahaan, tidak termasuk gedung, tanah, bangunan dan utang, disertai tanda tangan, materai 6000 dan stempel perusahaan

- Pasfoto Direktur Utama dengan ukuran 4 × 6/ $3 \times 42$ lembar/ 3 lembar ( Kebutuhan jumlah PasFoto bervariasi bergantung daerah tertentu)

- Materai Rp 6.000

- Izin teknis dari instansi terkait jika diminta

- Untuk Koperasi

- Fotokopi Kartu Tanda Penduduk (KTP) Dewan Pengurus dan Dewan Pengawas Koperasi

- Fotokopi NPWP Dewan Pengurus dan Dewan Pengawas Koperasi

- Fotokopi Akta Pendirian Koperasi yang telah disahkan instansi berwenang

- Daftar susunan Dewan Pengurus dan Dewan Pengawas

- Fotokopi SITU dari Pemerintah Daerah (Pemda)

- Neraca koperasi, tidak termasuk gedung, tanah, bangunan dan utang, disertai tanda tangan, materai 6000 dan stempel koperasi

- Materai senilai Rp 6.000

- Pasfoto Pengurus Utama dengan ukuran 4 × 6/ $3 \times 42$ lembar/ 3 lembar ( Kebutuhan jumlah PasFoto bervariasi bergantung daerah tertentu) 
- Izin lain yang terkait (Misalnya jika usaha Anda menghasilkan limbah, Anda harus memiliki izin AMDAL dari Badan pengendalian Dampak Lingkungan Daerah) setempat.

- Untuk CV dan Firma

- Fotokopi Kartu Tanda Penduduk (KTP) Para Sekutu

- Fotokopi NPWP Para Sekutu

- Fotokopi Akta Pendirian Firma/CV yang telah disahkan instansi berwenang

- Surat Keterangan Domisili Usaha atau SITU

- Neraca CV/ Firmai, tidak termasuk gedung, tanah, bangunan dan utang, disertai tanda tangan, materai 6000 dan stempel koperasi

- Materai senilai Rp6.000

- Pasfoto Pengurus Utama dengan ukuran 4 × 6/ $3 \times 42$ lembar/ 3 lembar ( Kebutuhan jumlah PasFoto bervariasi bergantung daerah tertentu)

- Izin lain yang terkait (Misalnya jika usaha Anda menghasilkan limbah, Anda harus memiliki izin AMDAL dari Badan pengendalian Dampak Lingkungan Daerah) setempat.

- Untuk Perusahaan Perseorangan

- Fotokopi Kartu Tanda Penduduk (KTP) Perusahaan Perseorangan

- Fotokopi NPWP

- Surat keterangan domisili atau SITU

- Neraca perusahaan, tidak termasuk gedung, tanah, bangunan dan utang, disertai tanda tangan, materai 6000 dan stempel usaha dagang

- Materai senilai Rp6.000

- Foto Direktur Utama/Penanggung Jawab/pemilik perusahaan dengan ukuran 4 x 6 $\mathrm{cm}$ (2 lembar).

- Izin lain yang terkait usaha yang dijalankan.

Prosedur yang perlu dilakukan untuk mendapakan izin SIUP dapat dilakukan di Kantor Dinas Perdagangan ataupun melalui Pelayanan Terpadu Satu Pintu di Beberapa Daerah. 
1. Tindakan yang dapat dilakukan pertama kali adalah mempersiapkan seluruh dokumen yang dibutuhkan dalam rangka pembuatan SIUP.

2. Mengambil formulir untuk permohonan SIUP di Kantor Dinas Perdagangan atau Pelayanan Terpadu Satu Pintu, kemudian melakukan pengisian terhadap formulir yang dan dibuat dalam 2 rangkap. Serta menyerahkan dokumen yang dibutuhkan untuk pembuatan SIUP. Apabila melalui kuasa dalam permohonan harus diberikan surat kuasa kepada para pihak yang dikuasakan dalam mengerjakan pengurusan.

3. Membayar Tarif pembuatan SIUP kepada loket ataupun rekening dari lembaga pemberi pendaftaran. Dibeberapa daerah pengurusan SIUP tidak dikenakan biaya sedikit pun.

\section{Tanda Daftar Perusahaan}

Dalam membuat sebuah Tanda Daftar Perusahaan setiap pelaku usaha wajib mempersiapkan beberapa dokumen sesuai bentuk badan Usahanya.

- Formulir diisi dan di Foto copy $2 X$

- Foto copy Akta Perusahaan/Akta Perubahan.

- Foto copy dan asli pengesahan dari kehakiman/pengadilan untuk CV dan FIRMA/ SK Pengesahan Kemenkumham untuk PT

- Foto copy SIUP atau Ijin Lainnya.

- Foto copy NPWP Perusahaan

- Foto copy KTP Direktur Utama

- Foto copy Domisili Perusahaan

Prosedur yang perlu dilakukan untuk mendapatkan TDP dapat dilakukan di Kantor Dinas Perdagangan ataupun melalui Pelayanan Terpadu Satu Pintu di Beberapa Daerah.

1. Tindakan yang dapat dilakukan pertama kali adalah mempersiapkan seluruh dokumen yang dibutuhkan dalam rangka pembuatan TDP.

2. Mengambil formulir untuk permohonan TDP di Kantor Dinas Perdagangan atau Pelayanan Terpadu Satu Pintu, kemudian melakukan pengisian terhadap formulir yang dan dibuat dalam 2 rangkap. Serta menyerahkan dokumen yang dibutuhkan untuk pembuatan TDP. Apabila melalui kuasa dalam permohonan harus diberikan surat kuasa kepada para pihak yang dikuasakan dalam mengerjakan pengurusan.

29 Kemendagri - sylabus - 2018 
3. Membayar Tarif pembuatan TDP kepada loket ataupun rekening dari lembaga pemberi pendaftaran. Dibeberapa daerah pengurusan TDP tidak dikenakan biaya.

\section{BPJS Ketenagakerjaan}

Dalam membuat sebuah BPJS Ketenagakerjaan setiap pelaku usaha wajib mempersiapkan beberapa dokumen sesuai bentuk badan Usahanya.

- Fotokopi dan aslinya SIUP (Surat Izin Usaha Perdagangan)

- Fotokopi dan aslinya NPWP Perusahaan

- Fotokopi dan aslinya Akta Perdagangan Perusahaan

- Fotokopi KTP (Kartu Tanda Penduduk) masing-masing karyawan,

- Fotokopi KK (Kartu Keluarga) karyawan/pekerja yang akan di daftar,

- Pas Foto berwarna Karyawan/pekerja ukuran 2×3 1 Lembar.

Prosedur yang perlu dilakukan untuk mendapakan BPJS Ketenagakerjaan dapat dilakukan di Kantor BPJS Ketenagakerjaan di Wilayah Domisili perusahaan ataupun melalui https://eps.bpjsketenagakerjaan.go.id/

1. Pendiri dapat melakukan pendaftaran terhadap kegiatan usaha melalui laman internet kemudian setelah dilakukan pendaftaran terhadap kegiatan usaha beserta dengan syaratsyarat yang ditentukan.

2. Pendiri melakukan pendaftaran terhadap pekerja-pekerja yang didaftarkan atas nama perusahaan beserta syarat-syarat yang ditentukan.

3. Menunggu jawaban dari pihak BPJS terkait dengan pendaftaran BPJS Ketenagakerjaan.

\section{Tanda Daftar Usaha Pariwisata}

Dalam membuat sebuah Tanda Daftar Usaha Pariwisata setiap pelaku usaha pariwisata wajib mempersiapkan beberapa dokumen sesuai bentuk badan Usahanya.

- Fotokopi akta pendirian badan usaha yang mencantumkan usaha pariwisata sebagai maksud dan tujuannya, beserta perubahannya apabila ada untuk pengusaha yang berbentuk badan hukum, atau fotokopi kartu tanda penduduk untuk pengusaha perseorangan.

- Fotokopi bukti hak pengelolaan dari pemilik usaha pariwisata.

30 Kemendagri - sylabus - 2018 
- Fotokopi izin teknis dan dokumen lingkungan hidup sebagai lampiran permohonan harus telah dilegalisir/disahkan oleh instansi teknis yang berwenang yaitu :

- Izin mendirikan bangunan ( IMB )

- Izin Gangguan ( $\mathrm{HO}$ )

- Surat Izin Tempat Usaha ( SITU )

- Amdal/UKL/UPL atau SPPL.

- Surat pernyataan keabsahan dan kebenaran dokumen

Prosedur yang perlu dilakukan untuk mendapakan Tanda Daftar Usaha Pariwisata dapat dilakukan di Kantor Dinas Pariwisata/Penanaman Modal ataupun melalui Pelayanan Terpadu Satu Pintu di Beberapa Daerah.

1. Tindakan yang dapat dilakukan pertama kali adalah mempersiapkan seluruh dokumen yang dibutuhkan dalam rangka pembuatan TDUP.

2. Mengambil formulir untuk permohonan TDUP di Kantor Dinas Pariwisata/Penanaman Modal atau Pelayanan Terpadu Satu Pintu, kemudian melakukan pengisian terhadap formulir yang dan dibuat dalam 2 rangkap. Serta menyerahkan dokumen yang dibutuhkan untuk pembuatan TDUP. Apabila melalui kuasa dalam permohonan harus diberikan surat kuasa kepada para pihak yang dikuasakan dalam mengerjakan pengurusan.

3. Membayar Tarif pembuatan TDUP kepada loket ataupun rekening dari lembaga pemberi pendaftaran. Dibeberapa daerah pengurusan TDUP tidak dikenakan biaya.

\section{Surat Keterangan Industri Kecil Rumah Tangga (SKIKRT)}

Dalam membuat sebuah SKIKRT setiap pelaku usaha pariwisata wajib mempersiapkan beberapa dokumen sesuai bentuk badan Usahanya.

a. Mengisi formulir permohonan

b. Fotokopi KTP pengurus

c. Fotokopi NPWP (Nomor Pokok Wajib pajak)

d. Fotokopi Akta Pendirian Perusahaan (bagi yang berbadan hukum)

e. Surat Keterangan Domisili Usaha

f. Kegiatan Usaha Produksi dengan Nilai investasi yang lebih dari Rp 50 juta harus melampirkan Izin Gangguan 
g. UKL/UPL (Upaya Pengelolaan Lingkungan dan Upaya pemantauan Lingkungan) atau SPPL (Surat Pernyataan Pengelolaan Lingkungan)

h. Pasfoto pengurus $4 \times 6$ sebanyak 2 lembar

Prosedur yang perlu dilakukan untuk mendapakan SKIKRT dapat dilakukan di Kantor Dinas Parindustrian ataupun melalui Pelayanan Terpadu Satu Pintu di Beberapa Daerah.

1. Tindakan yang dapat dilakukan pertama kali adalah mempersiapkan seluruh dokumen yang dibutuhkan dalam rangka pembuatan SKIKRT.

2. Mengambil formulir untuk permohonan SKIKRT di Kantor Dinas Perindustrian atau Pelayanan Terpadu Satu Pintu, kemudian melakukan pengisian terhadap formulir yang dan dibuat dalam 2 rangkap. Serta menyerahkan dokumen yang dibutuhkan untuk pembuatan SKIKRT. Apabila melalui kuasa dalam permohonan harus diberikan surat kuasa kepada para pihak yang dikuasakan dalam mengerjakan pengurusan.

3. Membayar Tarif pembuatan SKIKRT kepada loket ataupun rekening dari lembaga pemberi pendaftaran. Dibeberapa daerah pengurusan SKIKRT tidak dikenakan biaya.

\subsection{Studi Kasus}

1. Buatlah Dokumen persyaratan SIUP sesuai dengan dokumen-dokumen ataupun pengetahuan saudara terkait kegiatan usaha saudara. Dalam menentukan SIUP ini saudara dapat memilih 3 buah jenis usaha berdasarkan Klasifikasi Baku Lapangan Usaha yang dapat diunduh dari tautan ini:

http://www2.bkpm.go.id/images/uploads/prosedur_investasi/file_upload/KBLI-2015.pdf

\begin{tabular}{|l|l|}
\hline Nama Perusahaan & \\
\hline Bentuk Perusahaan & \\
\hline Merek & \\
\hline Alamat Perusahaan & \\
\hline
\end{tabular}




\begin{tabular}{|l|l|}
\hline Lokasi Perusahaan & \\
\hline Nomor Telepon/Fax & \\
\hline Status Tempat Usaha & \\
\hline Nomor Pokok Wajib Pajak (NPWP) & \\
\hline $\begin{array}{l}\text { Modal Disetor dan Kekayaan Bersih (Netto) } \\
\text { tidak termasuk tanah dan tempat usaha }\end{array}$ & \\
\hline $\begin{array}{l}\text { Kegiatan Usaha } \\
\text { Kelembagaan }\end{array}$ & \\
\hline $\begin{array}{l}\text { Bidang Usaha } \\
\text { Sesuai KBLI }\end{array}$ & \\
\hline Jenis barang/Jasa Dagangan Utama & \\
\hline
\end{tabular}

2. Perizinan apa sajakah yang telah anda miliki? Isilah kotak dibawah ini apabila anda telah memiliki izin-izin berikut:

\begin{tabular}{|c|c|c|c|}
\hline Jenis Izin & Nomor Izin & Tanggal Dikeluarkan & Tanggal Daluarsa \\
\hline SKDU & & & \\
\hline SIUP & & & \\
\hline TDP & & & \\
\hline NPWP & & & \\
\hline Izin Khusus: & & & \\
\hline
\end{tabular}




\section{Modul I}

\section{Jenis-Jenis Perizinan Usaha}

\section{Penjelasan Umum Modul Jenis-Jenis Perizinan Usaha}

Dalam Modul ini kami akan membahas mengenai Jenis-Jenis Perizinan Usaha.

Output:

- $\quad$ Peserta memahami jenis-jenis perizinan yang harus dimiliki

- $\quad$ Peserta memahami manfaat dari memiliki suatu izin usaha

- $\quad$ Peserta dapat menentukan perizinan yang tepat untuk usahanya

Estimasi durasi untuk mengerjakan secara mandiri : 1-2 jam

Dukungan yang dibutuhkan

- Pendampingan pemerintah daerah setempat untuk membantu melakukan pengurusan perizinan

- Membahas bersama UKM lain yang sejenis sektor usahanya perihal proses perizinan yang dipilih oleh mereka

5. Modul Jenis - Jenis Perizinan Usaha

\subsection{Jenis-Jenis Izin usaha di Indonesia}

\subsubsection{Perizinan Secara Umum}

5.12. Perijinan spesifik sesuai bidang usaha masing-masing

\subsection{Studi Kasus}




\subsection{Jenis-Jenis Izin usaha di Indonesia}

Secara Umum, Setiap usaha yang didirikan wajib memenuhi aspek perijinan yang ditetapkan yaitu:

- Surat Keterangan Domisili Usaha (SKDU),

- Nomor Pokok Wajib Pajak (NPWP),

- Surat Ijin Usaha Perdagangan (SIUP) dan

- Tanda Daftar Perusahaan.

- BPJS Ketenagakerjaan

Disamping perizinan secara umum tersebut, dalam beberapa bidang usaha juga diwajibkan memiliki ijin khusus yang disesuaikan dengan bidang usaha masingmasing.

\subsubsection{Perizinan Secara Umum}

\section{- Surat Keterangan Domisili Usaha (SKDU)}

Surat Ketarangan Domisili Usaha merupakan sebuah bentuk Izin yang memberikan gambaran kepada penyelenggara negara lainnya serta masyarakat umum untuk melihat apakah memang betul usaha tersebut melakukan kegiatan usaha di tempat tersebut. SKDU merupakan bagian awal perizinan yang wajib diikuti dan dipatuhi oleh kegiatan usaha yang menjadi kewajiban dari izin-izin lainnya.

\section{- Nomor Pokok Wajib Pajak (NPWP)}

Nomor Pokok Wajib Pajak merupakan sebuah bentuk tanda pengenal yang digunakan untuk mendapatkan hak dan kewajiban pajak dari wajib pajak sesuai dengan peraturan perundang-undangan. NPWP digunakan sebagai salah satu syarat yang wajib dilampirkan oleh badan usaha ataupun perseorangan dalam menjalankan kegiatan Usaha. Melalui NPWP maka dapat diketahui hak dan kewajiban pajak apakah telah dilaksanakan ataupun tidak dilaksanakan oleh wajib pajak.

\section{- Surat ljin Usaha Perdagangan (SIUP)}

Surat ljin Usaha Perdagangan merupakan sebuah bentuk izin yang memberikan gambaran kepada penyelenggara negara lainnya serta masyarakat umum untuk melihat jenis usaha apa yang akan dilaksanakan oleh kegiatan usaha serta 
kemampuan dari kegiatan usaha tersebut berdasarkan modal yang dimiliki perusahaan tersebut.

SIUP merupakan pengesahan dari pejabat yang berwenang dibidang perdagangan untuk pendiri dalam menjalankan kegiatan usahanya. Sebuah SIUP didasarkan kepada Modal yang disetorkan oleh pendiri dan Klasifikasi Baku Lapangan Usaha Indonesia (KLBI) yang memberikan gambaran kegiatan usaha tertentu masuk kedalam lingkup klasifikasi apa.

Terhadap setiap kegiatan usaha yang telah memberikan bukti terhadap bukti setor atas modal yang telah disetorkan dari sebuah kegiatan usaha mendapatkan beberapa klasifikasi SIUP sesuai dengan besarnya setoran tersebut.

- SIUP Mikro : SIUP yang dapat diberikan kepada Perusahaan Perdagangan Mikro, dengan modal dan kekayaan bersih seluruhnya tidak lebih dari Rp. 50 Juta.

- SIUP Kecil : wajib dimiliki oleh Perusahaan Perdagangan dengan modal dan kekayaan bersih (netto) seluruhnya sebesar Rp. 50 Juta sampai dengan Rp. 500 Juta, tidak termasuk tanah dan bangunan tempat usaha

- SIUP Menengah : wajib dimiliki oleh Perusahaan Perdagangan dengan modal dan kekayaan bersih (netto) seluruhnya sebesar Rp. 500 Juta sampai dengan Rp. 10 Milyar, tidak termasuk tanah dan bangunan tempat usaha

- SIUP Besar : wajib dimiliki oleh Perusahaan Perdagangan dengan modal dan kekayaan bersih (netto) seluruhnya lebih Rp. 10 Milyar, tidak termasuk tanah dan bangunan tempat usaha

Jenis SIUP akan mempengaruhi kemampuan dan kapabilitas dari sebuah kegiatan usaha dalam proses Tender. Apabila sebuah kegiatan usaha memiliki SIUP Mikro maka kegiatan usaha ini akan kesulitan untuk mengikuti Tender Pemerintah, sedangkan untuk SIUP Kecil tidak melakukan Tender dengan nilai Proyek diatas Rp 50.000.000,00(Lima Puluh Juta Rupiah).

\section{- Tanda Daftar Perusahaan (TDP)}

Tanda Daftar Perusahaan merupakan sebuah bentuk tanda yang menyatakan bahwa sebuah kegiatan usaha memang tercatat kepada negara dan seluruh kewajibankewajiban perizinan yang wajib dimiliki oleh sebuah kegiatan usaha telah dipenuhi. 


\section{- Badan Penyelenggara Jaminan Sosial (BPJS Ketenagakerjaan)}

BPJS Ketenagakerjaan merupakan sebuah kewajiban yang dibebankan kepada pemberi kerja (pelaku kegiatan usaha) kepada penerima kerja sebagai bentuk jaminan terhadap para pekerja dalam menjalankan kegiatan kerjanya. Didalam BPJS Ketenagakerjaan terdapat 4 buah program yang dapat diikuti oleh pekerja yaitu

- Jaminan Kecelakaan Kerja Jaminan Kecelakaan Kerja sebagai bentuk dari jaminan kepada para pekerja dalam menjalankan kegiatan usaha dari resiko sosial akibat adanya kondisi cacat atau kematian yang dideritka kepada pekerja. Setiap pemberi kerja wajib membayar iuaran jaminan kecelakaan kerja dari penerima kerja dengan kisaran $0,24 \%-1,74 \%$ sesuai kelompok jenis usaha.

- Jaminan Hari Tua

Jaminan Hari Tua sebagai bentuk jaminan kepada para pekerja dalam menjalankan kegiatan usaha dari resiko-resiko sosial ekonomi apabila pekerja kehilangan penghasilan di masa tua, Serta menjadi sarana jaminan penerimaan penghasilan tenaga kerja dan keluarga akibat adanya permasalahan dikemudian hari.

- Jaminan Kematian

Jaminan Kematian sebagai bentuk jaminan untuk memberikan keringanan kepada keluarga baik dalam bentuk biaya pemakaman maupun santunan kepada keluarga yang ditinggalkan oleh pekerja yang diakibatkan oleh Kecelakaan Kerja maupun bukan Kecelakaan Kerja.

- Jaminan Pemeliharaan Kesehatan

Jaminan Pemeliharaan Kesehatan merupakan hak para pekerja dan keluarga pekerja dalam memberikan bantuan dalam upaya penyelesaian masalahan kesehatan, mulai dari pencegahan, pelayanan di klinik kesehatan, rumah sakit dan kebutuhan terkait kesehatan lainnya yang dibuktikan dengan Pemberian Kartu Pemliharaan Kesehatan bagi para pekerja. 


\subsection{Perijinan spesifik sesuai bidang usaha masing-masing}

\section{Tanda Daftar Usaha Pariwisata}

Tanda Daftar Usaha Pariwisata adalah kewajiban terhadap penyelenggara kegiatan usaha yang berfokus pada kegiatan Pariwisata dan penunjang kegiatan pariwisata. Seluruh kegiatan pendaftaran ditekankan kepada pemerintah daerah dalam melakukan pengaturan dan pengawasan pelaksanaan kegiatan pariwisata yang menggunakan kekayaan alam dan budaya dari pemerintah Daerah.

\section{BIDANG USAHA PARIWISATA}

1. Bidang usaha daya tarik wisata meliputi jenis usaha :
a. Daya tarik wisata alam
b. Daya tarik wisata budaya
c. Daya tarik wisata buatan manusia

2. Bidang usaha kawasan pariwisata

3. Bidang usaha jasa transportasi wisata meliputi jenis usaha :
a. Angkutan jalan wisata

4. Bidang usaha jasa perjalanan wisata meliputi jenis usaha :
a. Biro perjalanan wisata
b. Agen perjalanan wisata

5. Bidang usaha jasa makanan dan minuman meliputi jenis usaha :
a. Restoran / rumah makan
b. Rumah minuman
c. Kafe
d. Pusat penjualan makanan
e. Jasa boga

6. Bidang usaha penyediaan akomodasi meliputi jenis usaha :
a. Hotel
b. Bumi perkemahan
c. Pondok wisata 
7. Bidang usaha penyelenggaraan kegiatan hiburan dan rekreasi meliputi jenis usaha :

a. Gelanggang olahraga meliputi sub jenis usaha :
i. Rumah bilyar
ii. Kolam renang
iii. Lapangan tenis
iv. Pusat kebugaran
v. Gelanggang bowling
vi. Lapangan futsal
vii. Lapangan bulutangkis
viii. Sasana tinju
ix. Lapangan sepakbola
x. Arena tenis meja

b. Gelanggang seni meliputi sub jenis usaha :

i. Gelanggang seni

ii. Galeri seni

iii. Gedung pertunjukan seni

c. Arena permainan meliputi sub jenis usaha :

i. Arena permainan anak dalam ruangan

ii. Arena permainan anak dalam arena terbuka

d. Panti pijat meliputi sub jenis usaha :

i. Panti pijat

ii. Refleksi

e. Taman rekreasi meliputi sub jenis usaha :

i. Taman rekreasi

ii. Taman bertema

f. Karaoke dan Studio musik

g. Jasa Impresariat / Promotor.

8. Bidang usaha penyelenggaraan pertemuan, perjalanan insentif,konferensi dan pameran.

9. Bidang usaha jasa informasi pariwisata 
10. Bidang usaha jasa konsultan pariwisata

11. Bidang usaha jasa pramusaji

12. Bidang usaha wisata tirta meliputi jenis usaha :

a. Wisata perairan meliputi sub Jenis usaha :

i. Wisata memancing.

13. Bidang usaha solus per aqua (SPA) meliputi jenis usaha :

a. Salon kecantikan

b. Solus per aqua

Selain dengan daftar kegiatan usaha yang tertampil diatas, terdapat beberap kegiatan yang masuk kedalam kualifikasi terkait dengan penyelenggaraan kegiatan usaha pariwisata seperti kegiatan wisata diving ataupun kegiatan transportasi perairan lainnya. Seluruh proses perizinan kegiatan wisata mengacu kepada peraturan pemerintah daerah tempat kegiatan usaha dilaksanakan dan akan berbeda-beda dari satu tempat dengan tempat lainnya.

Surat Keterangan Industri Kecil Rumah Tangga (SKIKRT)

Surat Keterangan Industri Kecil Rumah Tangga (SKIKRT) adalah kewajiban terhadap penyelenggara kegiatan usaha yang berfokus pada kegiatan Produksi dan pembuatan produk-produk dalam skala rumah tangga. Pendaftaran ini diberikan kepada penyelenggaraan kegiatan produk seperti kerajinan tangan, buah tangan atau pun kegiatan produksi yang bersifat rumahan.

\subsection{Studi Kasus}

Tentukan proses perizinan yang wajib dimiliki oleh kegiatan usaha anda berdasarkan dengan alasan mengapa izin tersebut wajib anda gunakan. Bila tidak wajib berikan alasan mengapa menjadi tidak wajib memiliki izin tersebut. 


\section{Modul I}

\section{Sistem Manajemen Mutu}

\section{Penjelasan Umum Modul}

\section{Modul Sistem Manajemen Mutu}

\subsubsection{Pemahaman Umum Manajemen Mutu}

\subsubsection{Manfaat Manajemen Mutu}

\subsubsection{Langkah - Langkah melakukan Manajemen Mutu}

Output:

- Peserta memahami apa itu Manajemen Kendali Mutu

- Peserta memahami manfaat Manajemen Kendali Mutu

- Peserta memahami langkah-langkah umum menuliskan dan melakukan Manajemen Kendali Mutu

Estimasi durasi untuk mengerjakan secara mandiri $\quad$ : 2-4 jam

Dukungan yang dibutuhkan

- Pendampingan Mentor untuk penulisan langkah-langkah Manajemen Mutu

- Audit panduan Manajemen Mutu

- Membahas bersama UKM lain, Manajemen Mutu 
Ketika Anda memulai modul ini, seharusnya Anda sudah membaca dan mengerjakan modul berikut:

1. Merumuskan Standar Produk/Jasa

2. Menyusun Standar Proses Produksi / Langkah Kerja

3. Menyusun Standar Bahan Baku / Alat Kerja

Jika belum, silakan Anda baca dan kerjakan dahulu modul yang masih terlewat.

Jika sudah, semua yang Anda baca dan kerjakan di modul terdahulu akan kita gunakan pada modul ini dan selanjutnya.

Setelah Anda mencoba menuliskan Standar Produk/Jasa, Standar Proses Produksi / Langkah Kerja, dan Standar Bahan Baku / Alat Kerja, pada modul ini Anda akan belajar bagaimana menggunakan Standar-Standar tersebut sebagai Sistem Manajemen Mutu.

Apa yang dimaksud di modul ini sebagai Sistem Manajemen Mutu?

Pada modul ini, pengertian Sistem Manajemen Mutu yang kita gunakan adalah $\rightarrow$ suatu alat/prosedur yang diterapkan dalam suatu organisasi, yang diterapkan untuk memberikan suatu transparansi mengenai aktivitas dalam organisasi.

Jadi kita ingin sama-sama membuat Standar-Standar yang Anda sudah susun dan tuliskan, sebagai bagian dari prosedur/sistem yang akan membuat kualitas UKM Anda secara terus menerus baik.

Bayangkan seseorang pengrajin yang kegiatannya adalah membuat sebuah patung atau seseorang mekanik yang kegiatannya adalah melakukan servis sepeda motor. Bagaimana caranya kita memastikan bahwa orang tersebut selalu membuat patung yang sama, dengan waktu yang sama dan hasil yang sama baiknya? Atau memastikan sang mekanik selalu menservis dengan langkah yang sama, dalam waktu yang sama dan dengan hasil yang sama? Standar yang sudah Anda susun tentu adalah jawabannya, tapi bagaimana memastikan standar tersebut selalu diikuti? Nah Sistem Manajemen Mutu adalah serangkaian cara/kegiatan untuk memastikan Standar tersebut selalu dipenuhi.

Tujuan Sistem Manajemen Mutu

1 Menjamin kesesuaian dari suatu proses dan produk terhadap kebutuhan atau persyaratan tertentu. 
2 Kesesuaian antara kebutuhan dan persyaratan yang ditetapkan pada suatu standar tertentu terhadap proses dan produk yang dihasilkan oleh perusahaan sangat penting.

3 Memberikan kepuasan kepada konsumen melalui pemenuhan kebutuhan dan persyaratan proses dan produk yang ditentukan pelanggan dan organisasi.

Sistem Manajemen Mutu sangat mengandalkan pada Standar yang tertulis dan kemudian dibuat menjadi semacam dokumen/formulir yang harus dijadikan panduan bagi orang-orang yang terlibat di UKM Anda.

Formulir-formulir tersebut yang harus digunakan setiap saat oleh setiap orang, terus menerus. Disiplin ini diperlukan agar bisa ada proses penelusuran kembali atas hal-hal yang terjadi, apakah sudah sesuai dengan standar atau belum.

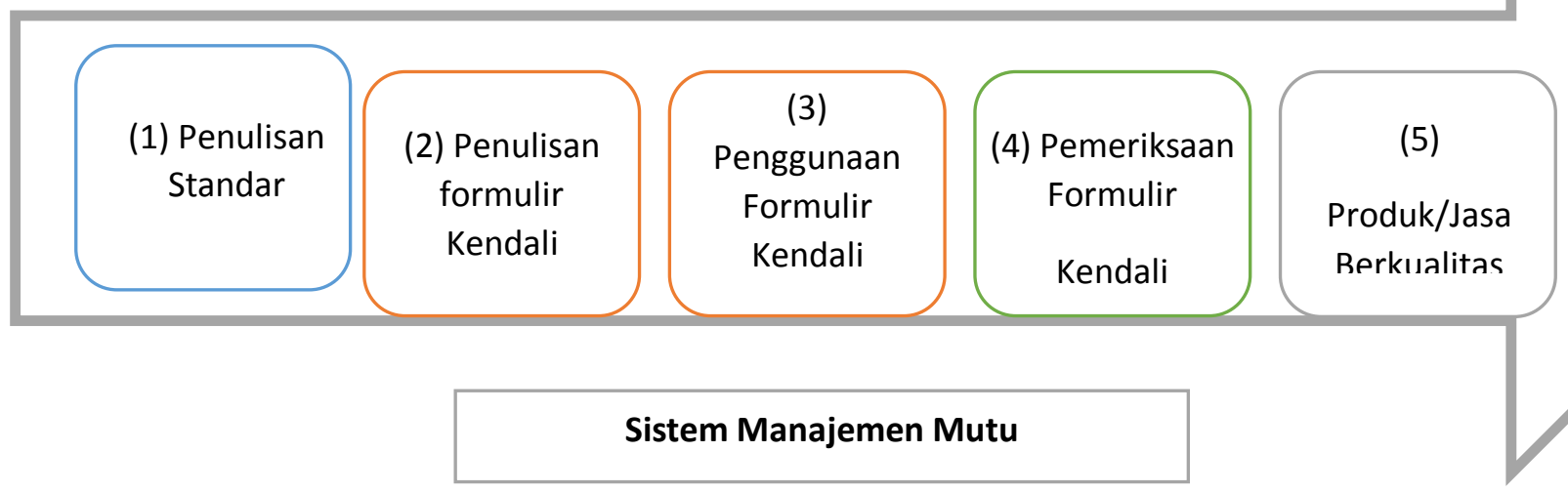

Kita sudah melalui tahap 1, dan akan belajar bagaimana melakukan tahap 2 di modul 5 . Manajemen Mutu Bahan Baku / Alat Kerja, Modul 6. Manajemen Mutu Proses Produksi / Langkah Kerja, Modul 7. Manajemen Mutu Produk / Jasa Akhir

Tahap 3 dan 4, akan dijelaskan singkat di Modul ini, sedangkan Tahap 5 merupakan Hasil Akhir yang akan Anda capai bila tahap 1 sampai dengan 4 dilakukan dengan baik dan terus menerus.

Pada tahap Penulisan Formulir yang Anda harus lakukan adalah:

1. Melihat lagi Standar Produk/Jasa yang Anda susun (Modul 1), Standar Proses Produksi / Langkah Kerja (Modul 2), dan Standar Bahan Baku / Alat Kerja (Modul 3)

2. Buat Standar tersebut menjadi formulir yang bisa digunakan untuk mengecek apakah standar tersebut sudah terpenuhi/terlaksana

43 Kemendagri - sylabus - 2018 
Contohnya adalah sebagai berikut

Contoh Formulir Kendali Bahan Baku / Alat Kerja

\begin{tabular}{|c|c|c|c|}
\hline \multicolumn{2}{|c|}{ Nomor Formulir : 1.1} & \multicolumn{2}{|c|}{ Diisi oleh $\quad$ : [nama yang mengisi] } \\
\hline $\begin{array}{l}\text { No. } \\
\text { Urut }\end{array}$ & $\begin{array}{l}\text { Bahan Baku/ Alat } \\
\text { Kerja }\end{array}$ & Standar Kualitas/Spesifikasi & Terpenuhi \\
\hline \multicolumn{4}{|l|}{1} \\
\hline \multicolumn{4}{|l|}{2} \\
\hline \multicolumn{4}{|l|}{3} \\
\hline \multicolumn{3}{|c|}{ Hasil Kendali Kesesuaian dengan Standar } & _ dari___ \\
\hline \multirow{2}{*}{\multicolumn{2}{|c|}{$\begin{array}{l}\text { Dicek oleh: [nama orang yang } \\
\text { memeriksa] } \\
\text { Hasil Pemeriksaan: Sesuai/Tidak } \\
\text { Sesuai }\end{array}$}} & \multicolumn{2}{|l|}{ Tanggal pengisian } \\
\hline & & $\begin{array}{l}\text { Tanggal } \\
\text { Pemeriksaaan }\end{array}$ & \\
\hline
\end{tabular}

Dengan formulir ini, 1 orang dari UKM Anda yang tugasnya memeriksa Bahan Baku/Alat Kerja bisa menggunakan formulir ini untuk memeriksa Bahan Baku / Alat Kerja yang akan digunakan, apakah sudah sesuai dengan Standar Bahan Baku / Alat Kerja

Contoh Formulir Kendali Proses Produksi / Langkah Kerja

\begin{tabular}{|c|l|l|l|}
\hline \multicolumn{2}{|l|}{ Nomor Formulir : 2.1 } & Diisi oleh : [nama yang mengisi] \\
\hline $\begin{array}{l}\text { No. } \\
\text { Urut }\end{array}$ & $\begin{array}{l}\text { Proses Produksi / } \\
\text { Langkah Kerja }\end{array}$ & Standar & Terpenuhi \\
\hline 1 & & & \\
\hline 3 & & & - dari \\
\hline Hasil Kendali Kesesuaian dengan Standar & \\
\hline $\begin{array}{l}\text { Dicek oleh: [nama orang yang } \\
\text { memeriksa] }\end{array}$ & $\begin{array}{l}\text { Tanggal } \\
\text { pengisian } \\
\text { Hasil Pemeriksaan: Sesuai/Tidak } \\
\text { Sesuai }\end{array}$ & $\begin{array}{l}\text { Tanggal } \\
\text { Pemeriksaan }:\end{array}$ \\
\hline
\end{tabular}


Dengan formulir ini, 1 orang dari UKM Anda yang tugasnya memeriksa Bahan Baku/Alat Kerja bisa menggunakan formulir ini untuk memeriksa Bahan Baku / Alat Kerja yang akan digunakan, apakah sudah sesuai dengan Standar Proses Produksi / Langkah Kerja

\section{Contoh Formulir Kendali Kualitas Produk / Jasa Akhir}

\begin{tabular}{|c|c|c|c|c|}
\hline \multicolumn{2}{|c|}{ Nomor Formulir : 3.1} & \multicolumn{3}{|c|}{ : [nama yang mengisi] } \\
\hline $\begin{array}{l}\text { No. } \\
\text { Urut }\end{array}$ & Kriteria Kualitas & & Standar & Terpenuhi \\
\hline 1 & Warna & & & \\
\hline 2 & Ukuran & & & \\
\hline 3 & Berat & & & \\
\hline 4 & Kerapihan & & & \\
\hline \multicolumn{4}{|c|}{ Hasil Kendali Kesesuaian dengan Standar } & _ dari __ \\
\hline \multirow{2}{*}{\multicolumn{2}{|c|}{$\begin{array}{l}\text { Dicek oleh: [nama orang yang } \\
\text { memeriksa] } \\
\text { Hasil Pemeriksaan: Sesuai/Tidak } \\
\text { Sesuai }\end{array}$}} & \multicolumn{3}{|c|}{$\begin{array}{ll}\text { Tanggal } & : \\
\text { pengisian } & \end{array}$} \\
\hline & & \multicolumn{3}{|l|}{$\begin{array}{l}\text { Tanggal } \\
\text { Pemeriksaaan }\end{array}$} \\
\hline
\end{tabular}

Dengan formulir ini, 1 orang dari UKM Anda yang tugasnya memeriksa Bahan Baku/Alat Kerja bisa menggunakan formulir ini untuk memeriksa Bahan Baku / Alat Kerja yang akan digunakan, apakah sudah sesuai dengan Standar Proses Produksi / Langkah Kerja

Formulir-formulir tersebut harus dibiasakan untuk diisi secara teratur, misalnya:

- Formulir Kendali Bahan Baku / Alat Kerja, diisi setiap sebelum proses produksi atau kegiatan kerja dimulai

- Formulir Kendali Proses Produksi / Langkah Kerja, diisi selama proses produksi / kegiatan kerja setiap selesai 1 tahap

- Formulir Kendali Kualitas Produk / Jasa akhir, diisi setelah produk/jasa selesai Juga harus ditugaskan orang-orang tertentu yang bertugas mengisi dan memeriksa lembar isiannya. 
Orang yang bertugas mengisi, biasanya adalah orang yang memang bertanggung jawab langsung (tentang pengadaan bahan baku, tentang proses produksi / langkah kerja dan tentang penyelesaian produk).

Orang yang bertugas memeriksa, sebaiknya adalah orang yang menjadi atasan/koordinator dari orang yang bertanggung jawab langsung.

Selamat! Ini langkah tambahan agar UKM Anda memiliki kualitas yang baik dan konsisten.

Setelah mengerjakan Modul ini, Anda seharusnya sudah:

○ memahami apa itu Sistem Manajemen Mutu

○ sadar manfaat memiliki Sistem Manajemen Mutu

○ memahami komponen Sistem Manajemen Mutu, dan

○ memahami contoh-contoh Formulir Kendali

Bila ada yang belum anda pahami dan, mohon tandai dengan ' $x$ ' di daftar di atas. Tuliskan di kotak bawah, hal-hal yang masih Anda anggap kurang jelas atau Anda ingin ketahui lebih lanjut:

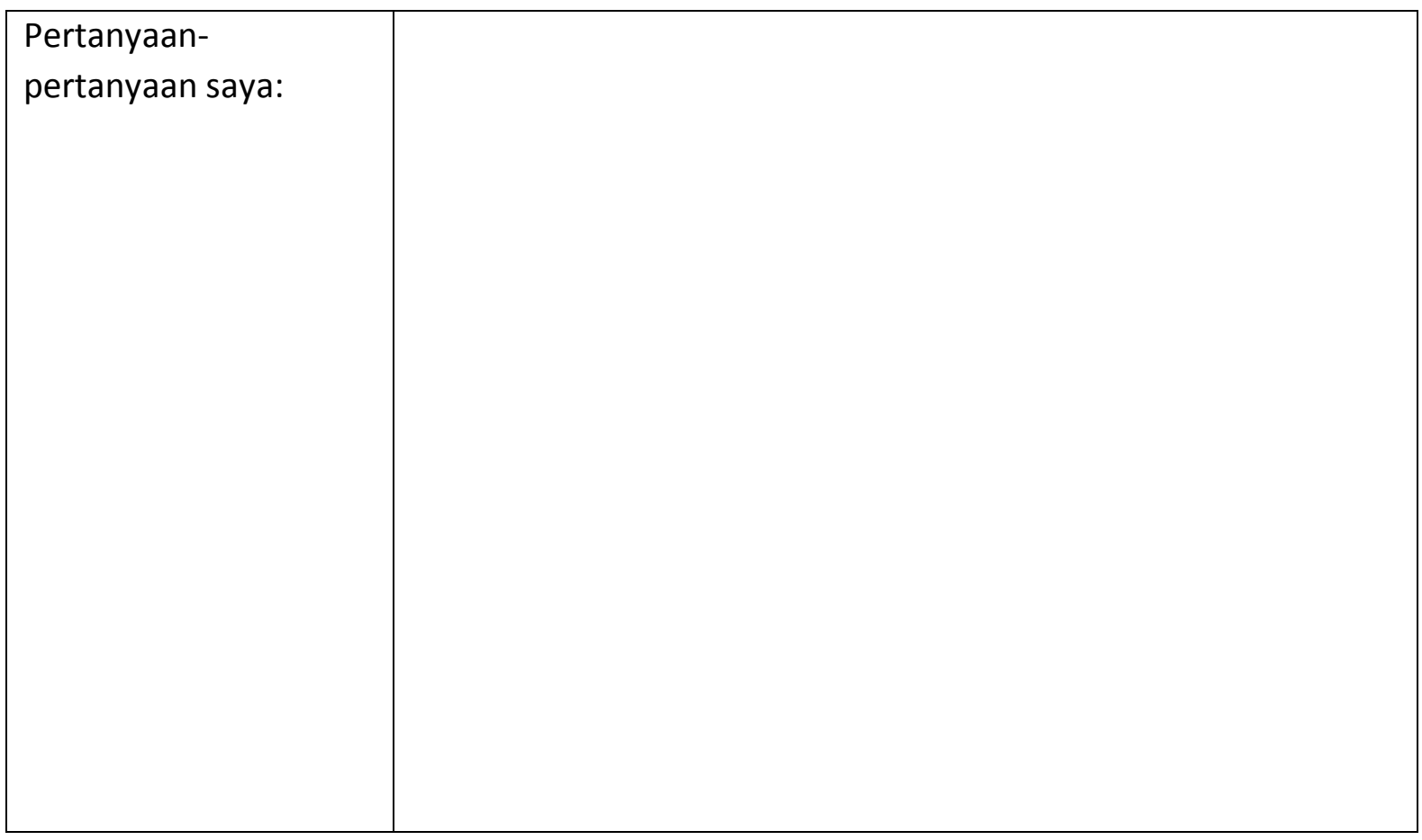

Lalu hubungi TIM Pendamping terdekat.

Anda siap untuk melanjutkan ke Modul selanjutnya! 


\section{Modul I}

7.Sistem Manajemen Mutu Proses Produksi / Langkah Kerja

\section{Penjelasan Umum Modul}

7. Modul Sistem Manajemen Mutu Proses Produksi / Langkah Kerja

\subsubsection{Pemahaman Umum Manajemen Mutu Proses Produksi / Langkah Kerja}

\subsubsection{Manfaat Manajemen Mutu Proses Produksi / Langkah Kerja}

\subsubsection{Langkah - Langkah melakukan Manajemen Mutu Proses Produksi / Langkah Kerja} Output:

- Peserta memahami apa itu Manajemen Mutu Proses Produksi / Langkah Kerja

- Peserta memahami manfaat Manajemen Mutu Proses Produksi / Langkah Kerja

- Peserta memahami langkah-langkah umum menuliskan dan melakukan Manajemen Mutu Proses Produksi / Langkah Kerja

Estimasi durasi untuk mengerjakan secara mandiri $\quad$ : 2-4 jam Dukungan yang dibutuhkan

- Pendampingan Mentor untuk penulisan langkah-langkah Manajemen Mutu Proses Produksi / Langkah Kerja

- Audit panduan Manajemen Mutu Proses Produksi / Langkah Kerja

- Membahas bersama UKM lain, Manajemen Mutu Proses Produksi / Langkah Kerja masing-masing 
Ketika Anda memulai modul ini, seharusnya Anda sudah membaca dan mengerjakan modul berikut:

1. Merumuskan Standar Produk/Jasa

2. Menyusun Standar Proses Produksi / Langkah Kerja

3. Menyusun Standar Bahan Baku / Alat Kerja

4. Manajemen Mutu

Jika belum, silakan Anda baca dan kerjakan dahulu modul yang masih terlewat.

Jika sudah, semua yang Anda baca dan kerjakan di modul terdahulu akan kita gunakan pada modul ini dan selanjutnya.

Setelah Anda memahami konsep dasar Manajemen Mutu dan melihat berbagai contoh formulirnya, kita akan fokus mengembangkan Manajemen Mutu Proses Produksi / Langkah Kerja.

\section{Contoh Pembuatan \& Pengisian Formulir Kendali Proses Produksi / Langkah Kerja} Langkah 1

\begin{tabular}{|c|c|c|c|}
\hline \multicolumn{2}{|c|}{ Nomor Formulir : 2.1} & \multicolumn{2}{|c|}{ Diisi oleh $\quad$ : [nama yang mengisi] } \\
\hline $\begin{array}{l}\text { No. } \\
\text { Urut }\end{array}$ & $\begin{array}{l}\text { Proses Produksi / } \\
\text { Langkah Kerja }\end{array}$ & Standar & Terpenuhi \\
\hline \multicolumn{4}{|l|}{1} \\
\hline \multicolumn{4}{|l|}{2} \\
\hline \multicolumn{4}{|l|}{3} \\
\hline \multicolumn{3}{|c|}{ Hasil Kendali Kesesuaian dengan Standar } & _ dari __ \\
\hline \multirow{2}{*}{\multicolumn{2}{|c|}{$\begin{array}{l}\text { Dicek oleh: [nama orang yang } \\
\text { memeriksa] } \\
\text { Hasil Pemeriksaan: Sesuai/Tidak }\end{array}$}} & \multicolumn{2}{|l|}{$\begin{array}{l}\text { Tanggal } \\
\text { pengisian }\end{array}$} \\
\hline & & \multicolumn{2}{|l|}{$\begin{array}{l}\text { Tanggal } \\
\text { Pemeriksaaan }\end{array}$} \\
\hline
\end{tabular}

Pada bagian yang diberi warna hijau, tuliskan nomor kode formulir yang akan UKM Anda tetapkan untuk proses kendali Standar Proses Produksi / Langkah Kerja. Untuk mempermudah, saran kami beri nomor kode 1.1, bila kemudian UKM Anda mengembangkan formulir baru, lanjutkan penomoran/kode menjadi 1.2, 1.3 dan seterusnya. 


\section{Langkah 2}

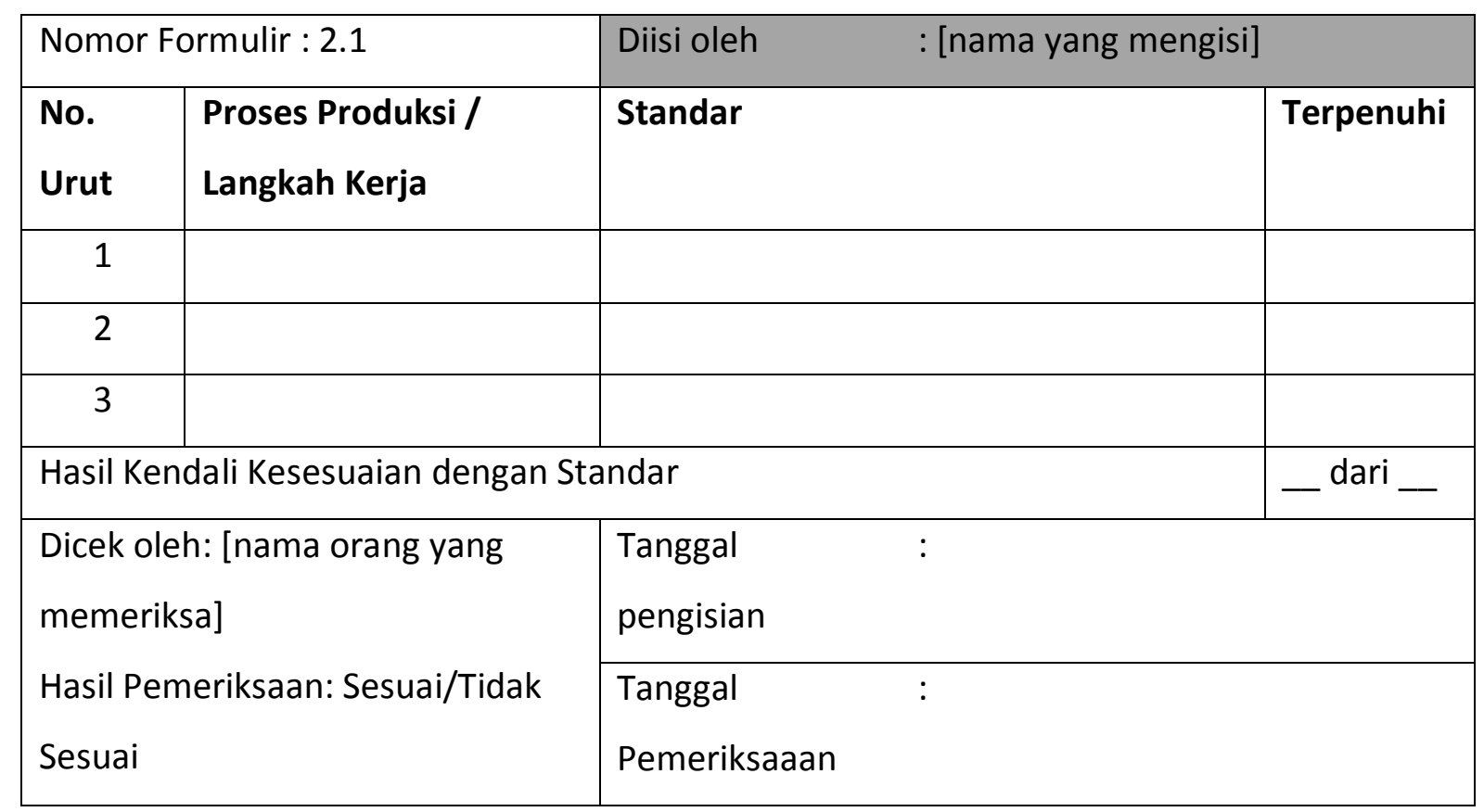

Pada bagian ini yang sekarang diwarnai hijau, sebaiknya diisi oleh orang/staf UKM Anda yang tugasnya berhubungan langsung dengan proses produksi. Bisa jadi orangnya bukan hanya 1 orang, tetapi harus jelas siapa saja yang bertanggung jawab untuk mengisi lembar ini bahkan bila bergantian.

\section{Langkah 3}

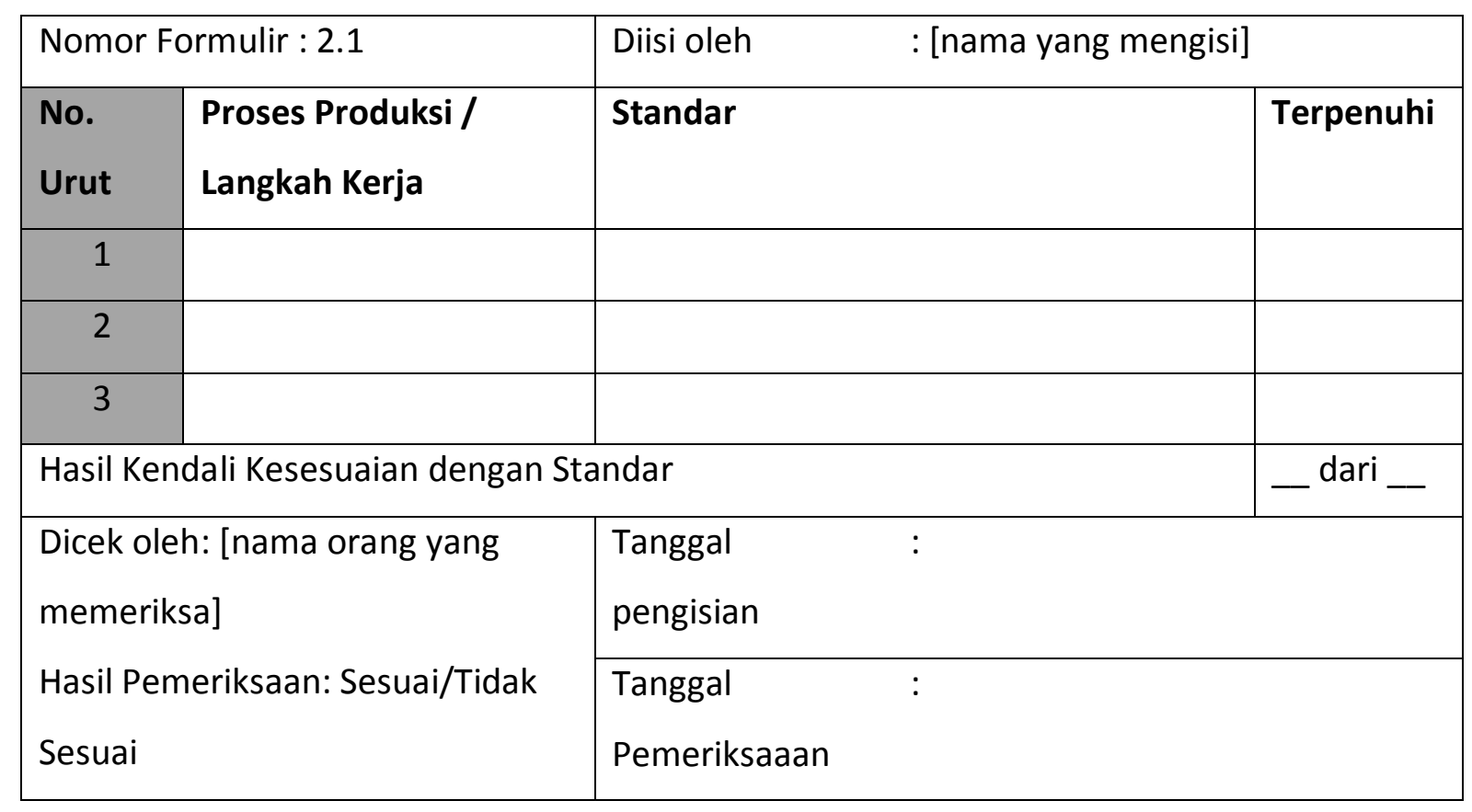

Pada bagian ini yang sekarang diwarnai hijau, merupakan bagian yang diisi dengan nomor urut Proses Produksi / Langkah Kerja. Jumlah nomor urut tergantung berapa banyak Bahan 
Baku / Alat Kerja yang tercantum di daftar Standar Proses Produksi / Langkah Kerja yang sudah Anda tuliskan sebelumnya. Tambahkan sesuai dengan jumlah dan urutan Proses Produksi / Langkah Kerja di daftar Anda.

\section{Langkah 4}

\begin{tabular}{|c|l|l|l|}
\hline \multicolumn{2}{|l|}{ Nomor Formulir : 2.1 } & Diisi oleh : [nama yang mengisi] \\
\hline $\begin{array}{l}\text { No. } \\
\text { Urut }\end{array}$ & $\begin{array}{l}\text { Proses Produksi / } \\
\text { Langkah Kerja }\end{array}$ & Standar & Terpenuhi \\
\hline 1 & & & \\
\hline 2 & & & \\
\hline 3 & & & \\
\hline Hasil Kendali Kesesuaian dengan Standar & dari \\
\hline $\begin{array}{l}\text { Dicek oleh: [nama orang yang } \\
\text { memeriksa] }\end{array}$ & Tanggal \\
Hasil Pemeriksaan: Sesuai/Tidak & pengisian & Tanggal & \\
\cline { 2 - 4 } Sesuai & Pemeriksaan & \\
\hline
\end{tabular}

Pada bagian ini yang sekarang diwarnai hijau, merupakan bagian yang diisi nama-nama/daftar bahan baku sesuai yang sudah Anda tulis di Standar Proses Produksi / Langkah Kerja. Tambahkan baris sesuai dengan jumlah tahapan Proses Produksi / Langkah Kerja, sampai semuanya terdaftar di form ini

\section{Langkah 5}

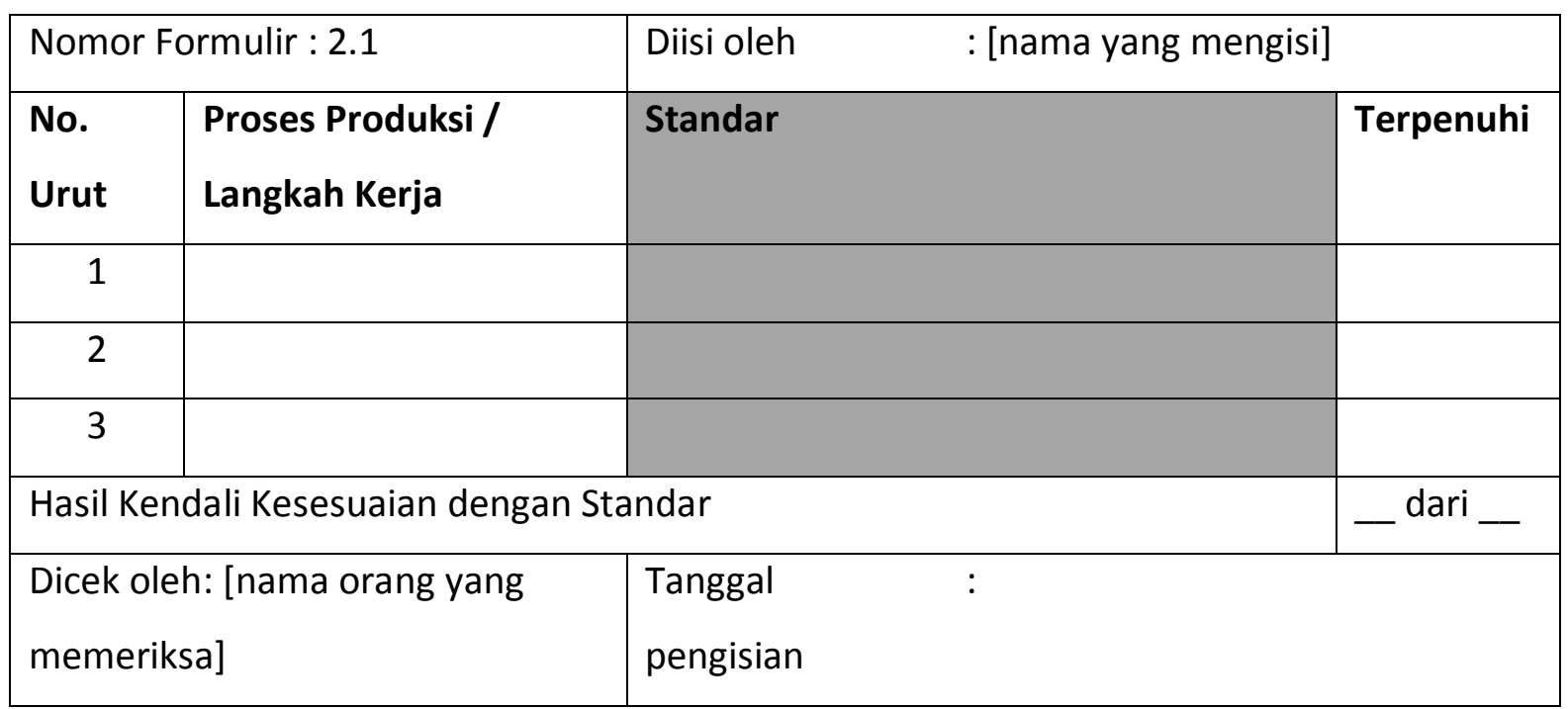




\begin{tabular}{|l|l|}
\hline $\begin{array}{l}\text { Hasil Pemeriksaan: Sesuai/Tidak } \\
\text { Sesuai }\end{array}$ & $\begin{array}{l}\text { Tanggal : } \\
\text { Pemeriksaaan }\end{array}$ \\
\hline
\end{tabular}

Pada bagian ini yang sekarang diwarnai hijau, merupakan bagian yang standar kualitas / spesifikasi Bahan Baku / Alat Kerja yang sudah Anda tuliskan di Standar Proses Produksi / Langkah Kerja. Biasanya di bagian ini tertulis durasi pengerjaan atau hasil kerja minimal direncanakan.

\section{Langkah 6}

\begin{tabular}{|c|c|c|c|c|}
\hline \multicolumn{2}{|c|}{ Nomor Formulir : 2.1} & \multicolumn{3}{|c|}{ : [nama yang mengisi] } \\
\hline $\begin{array}{l}\text { No. } \\
\text { Urut }\end{array}$ & $\begin{array}{l}\text { Proses Produksi / } \\
\text { Langkah Kerja }\end{array}$ & Standar & & Terpenuhi \\
\hline 1 & & & & $\checkmark$ \\
\hline 2 & & & & $\checkmark$ \\
\hline 3 & & & & $x$ \\
\hline \multicolumn{4}{|c|}{ Hasil Kendali Kesesuaian dengan Standar } & _ dari __ \\
\hline \multirow{2}{*}{\multicolumn{2}{|c|}{$\begin{array}{l}\text { Dicek oleh: [nama orang yang } \\
\text { memeriksa] } \\
\text { Hasil Pemeriksaan: Sesuai/Tidak } \\
\text { Sesuai }\end{array}$}} & \multicolumn{3}{|c|}{$\begin{array}{l}\text { Tanggal } \\
\text { pengisian }\end{array}$} \\
\hline & & \multicolumn{3}{|c|}{$\begin{array}{l}\text { Tanggal } \\
\text { Pemeriksaaan }\end{array}$} \\
\hline
\end{tabular}

Pada bagian ini yang sekarang diwarnai hijau, merupakan bagian di mana orang yang mengisi harus memberi tanda apakah Standar Proses Produksi / Langkah Kerja yang ia kerjakan, sudah memenuhi Standar Kualitas yang diharapkan. Beri tanda $\checkmark$ bila memenuhi Standar Proses Produksi / Langkah Kerja yang sudah Anda tuliskan sebelumnya. Beri tanda? $\boldsymbol{X}$ bila tidak memenuhi. 
52 Kemendagri - sylabus - 2018 


\section{Langkah 7}

\begin{tabular}{|c|c|c|c|}
\hline \multicolumn{2}{|c|}{ Nomor Formulir : 2.1} & \multicolumn{2}{|c|}{ Diisi oleh $\quad$ : [nama yang mengisi] } \\
\hline $\begin{array}{l}\text { No. } \\
\text { Urut }\end{array}$ & $\begin{array}{l}\text { Proses Produksi / } \\
\text { Langkah Kerja }\end{array}$ & Standar & Terpenuhi \\
\hline 1 & & & $\checkmark$ \\
\hline 2 & & & $\checkmark$ \\
\hline 3 & & & $x$ \\
\hline \multicolumn{3}{|c|}{ Hasil Kendali Kesesuaian dengan Standar } & _ dari __ \\
\hline \multirow{2}{*}{\multicolumn{2}{|c|}{$\begin{array}{l}\text { Dicek oleh: [nama orang yang } \\
\text { memeriksa] } \\
\text { Hasil Pemeriksaan: Sesuai/Tidak } \\
\text { Sesuai }\end{array}$}} & \multicolumn{2}{|l|}{$\begin{array}{l}\text { Tanggal } \\
\text { pengisian }\end{array}$} \\
\hline & & \multicolumn{2}{|l|}{$\begin{array}{l}\text { Tanggal } \\
\text { Pemeriksaaan }\end{array}$} \\
\hline
\end{tabular}

Pada bagian ini yang sekarang diwarnai hijau, merupakan bagian di mana orang yang mengisi harus menghitung, ada berapa tanda $\checkmark$ dari keseluruhan jumlah Bahan Baku yang terdaftar. Dalam contoh ini misalnya, 2 dari 3.

\section{Langkah 8}

\begin{tabular}{|c|l|l|c|}
\hline \multicolumn{2}{|l|}{ Nomor Formulir : 2.1 } & Diisi oleh : [nama yang mengisi] \\
\hline $\begin{array}{l}\text { No. } \\
\text { Urut }\end{array}$ & $\begin{array}{l}\text { Proses Produksi / } \\
\text { Langkah Kerja }\end{array}$ & Standar & Terpenuhi \\
\hline 1 & & & $\checkmark$ \\
\hline 2 & & & $\boldsymbol{X}$ \\
\hline 3 & & & dari \\
\hline Hasil Kendali Kesesuaian dengan Standar & \\
\hline $\begin{array}{l}\text { Dicek oleh: [nama orang yang } \\
\text { memeriksa] }\end{array}$ & Tanggal \\
Hasil Pemeriksaan: Sesuai/Tidak & pengisian & Tanggal & \\
\hline Sesuai & Pemeriksaan & \\
\hline
\end{tabular}


Pada bagian ini yang sekarang diwarnai hijau, merupakan bagian di mana ada orang (selain yang mengisi) yang bertanggung jawab untuk memeriksa apakah formulir isian ini telah diisi dengan secara sesuai (antara isian dengan kondisi Proses Produksi / Langkah Kerja yang sebenarnya). Yang melakukan pemeriksaan sebaiknya adalah seseorang yang menjadi atasan dari orang yang bertanggung jawab langsung atas produksi / kerja

\section{Langkah 9}

\begin{tabular}{|c|c|c|c|}
\hline \multicolumn{2}{|c|}{ Nomor Formulir : 2.1} & \multicolumn{2}{|c|}{ Diisi oleh $\quad$ : [nama yang mengisi] } \\
\hline $\begin{array}{l}\text { No. } \\
\text { Urut }\end{array}$ & $\begin{array}{l}\text { Proses Produksi / } \\
\text { Langkah Kerja }\end{array}$ & Standar & Terpenuhi \\
\hline 1 & & & $\checkmark$ \\
\hline 2 & & & $\checkmark$ \\
\hline 3 & & & $x$ \\
\hline \multicolumn{3}{|c|}{ Hasil Kendali Kesesuaian dengan Standar } & _ dari __ \\
\hline \multirow{2}{*}{\multicolumn{2}{|c|}{$\begin{array}{l}\text { Dicek oleh: [nama orang yang } \\
\text { memeriksa] } \\
\text { Hasil Pemeriksaan: Sesuai/Tidak } \\
\text { Sesuai }\end{array}$}} & \multicolumn{2}{|l|}{$\begin{array}{l}\text { Tanggal } \\
\text { pengisian }\end{array}$} \\
\hline & & \multicolumn{2}{|l|}{$\begin{array}{l}\text { Tanggal } \\
\text { Pemeriksaaan }\end{array}$} \\
\hline
\end{tabular}

Pada bagian ini yang sekarang diwarnai hijau, merupakan bagian diisi dengan tanggal formulir ini diisi untuk memeriksa Proses Produksi / Langkah KErja Langkah 10

\begin{tabular}{|c|c|c|c|c|}
\hline \multicolumn{2}{|c|}{ Nomor Formulir : 2.1} & \multicolumn{3}{|c|}{ Diisi oleh $\quad$ : [nama yang mengisi] } \\
\hline $\begin{array}{l}\text { No. } \\
\text { Urut }\end{array}$ & $\begin{array}{l}\text { Proses Produksi / } \\
\text { Langkah Kerja }\end{array}$ & Standar & & Terpenuhi \\
\hline 1 & & & & $\checkmark$ \\
\hline 2 & & & & $\checkmark$ \\
\hline 3 & & & & $x$ \\
\hline \multicolumn{4}{|c|}{ Hasil Kendali Kesesuaian dengan Standar } & _ dari _ \\
\hline \multirow{2}{*}{\multicolumn{2}{|c|}{$\begin{array}{l}\text { Dicek oleh: [nama orang yang } \\
\text { memeriksa] } \\
\text { Hasil Pemeriksaan: Sesuai/Tidak } \\
\text { Sesuai }\end{array}$}} & \multicolumn{3}{|c|}{$\begin{array}{l}\text { Tanggal : } \\
\text { pengisian }\end{array}$} \\
\hline & & \multicolumn{3}{|l|}{$\begin{array}{l}\text { Tanggal } \\
\text { Pemeriksaaan }\end{array}$} \\
\hline
\end{tabular}


Pada bagian ini yang sekarang diwarnai hijau, merupakan bagian diisi dengan tanggal formulir ini diperiksa oleh Pengecek.

Formulir ini harus dibiasakan untuk diisi secara teratur, misalnya:

- Formulir Kendali Proses Produksi / Langkah Kerja ini, diisi setiap selesai 1 tahap/langkah proses produksi atau kegiatan kerja dimulai

- Lalu dicek segera sebelum proses produksi atau kegiatan kerja dilanjutkan Formulir yang sudah terisi, sebaiknya diarsipkan/disimpan sesuai dengan tanggal pengisian dan/ disatukan dengan Formulir Kendali Bahan Baku / Alat Produksi dan Formulir Kendali Hasil Akhir utk periode produksi / kegiatan jasa yang sama (hari yang sama, minggu yang sama atau bulan yang sama)

Selamat! Ini langkah tambahan agar UKM Anda memiliki kualitas yang baik dan konsisten. Setelah mengerjakan Modul ini, Anda seharusnya sudah:

- memahami apa itu Manajemen Proses Produksi / Langkah Kerja

- Memahami langkah-langkah pengisian Formulir Kendali Proses Produksi / Langkah Kerja

Bila ada yang belum anda pahami dan, mohon tandai dengan ' $x$ 'di daftar di atas. Tuliskan di kotak bawah, hal-hal yang masih Anda anggap kurang jelas atau Anda ingin ketahui lebih lanjut:

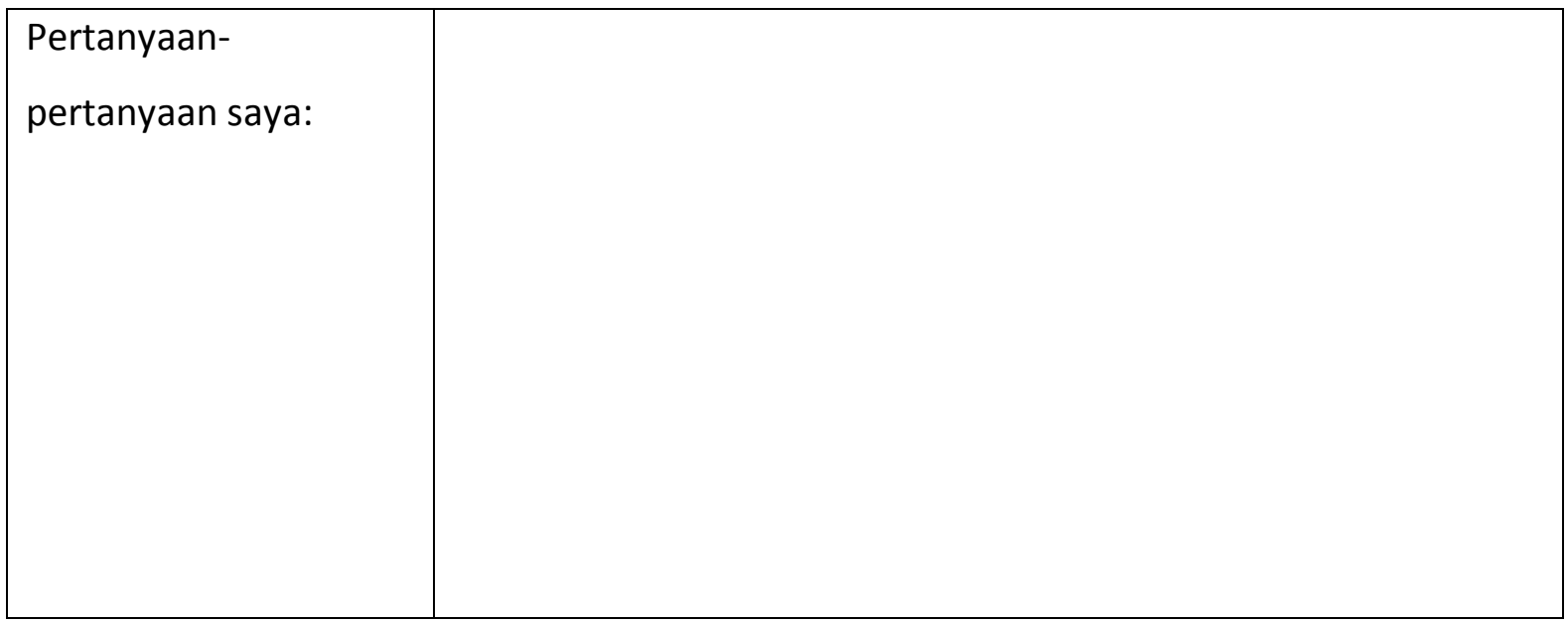

Lalu hubungi TIM Pendamping terdekat.

Anda siap untuk melanjutkan ke Modul selanjutnya!

55 Kemendagri - sylabus - 2018 


\section{Modul I}

\section{Sistem Manajemen Mutu Bahan Baku / Alat Kerja}

\section{Penjelasan Umum Modul}

8. Modul Sistem Manajemen Mutu Bahan Baku / Alat Kerja

\subsubsection{Pemahaman Umum Manajemen Mutu Bahan Baku / Alat Kerja}

\subsubsection{Manfaat Manajemen Mutu Bahan Baku / Alat Kerja}

\subsubsection{Langkah - Langkah melakukan Manajemen Mutu Bahan Baku / Alat Kerja}

Output:

- Peserta memahami apa itu Manajemen Mutu Bahan Baku

- Peserta memahami manfaat Manajemen Mutu Bahan Baku / Alat Kerja

- Peserta memahami langkah-langkah umum menuliskan dan melakukan Manajemen Mutu Bahan Baku / Alat Kerja

Estimasi durasi untuk mengerjakan secara mandiri

Dukungan yang dibutuhkan

- Pendampingan Mentor untuk penulisan langkah-langkah Manajemen Mutu Bahan Baku / Alat Kerja

- Audit panduan Manajemen Mutu Bahan Baku / Alat Kerja

- Membahas bersama UKM lain, Manajemen Mutu Bahan Baku / Alat Kerja masingmasing. 
Ketika Anda memulai modul ini, seharusnya Anda sudah membaca dan mengerjakan modul berikut:

1. Merumuskan Standar Produk/Jasa

2. Menyusun Standar Proses Produksi / Langkah Kerja

3. Menyusun Standar Bahan Baku / Alat Kerja

4. Manajemen Mutu

Jika belum, silakan Anda baca dan kerjakan dahulu modul yang masih terlewat.

Jika sudah, semua yang Anda baca dan kerjakan di modul terdahulu akan kita gunakan pada modul ini dan selanjutnya.

Setelah Anda memahami konsep dasar Manajemen Mutu dan melihat berbagai contoh formulirnya, kita akan fokus mengembangkan Manajemen Mutu Bahan Baku / Alat Kerja.

Contoh Pembuatan \& Pengisian Formulir Kendali Bahan Baku / Alat Kerja

\section{Langkah 1}

\begin{tabular}{|c|c|c|c|}
\hline \multicolumn{2}{|c|}{ Nomor Formulir : 1.1} & \multicolumn{2}{|c|}{ Diisi oleh $\quad$ : [nama yang mengisi] } \\
\hline $\begin{array}{l}\text { No. } \\
\text { Urut }\end{array}$ & $\begin{array}{l}\text { Bahan Baku/ Alat } \\
\text { Kerja }\end{array}$ & Standar Kualitas/Spesifikasi & Terpenuhi \\
\hline \multicolumn{4}{|l|}{1} \\
\hline \multicolumn{4}{|l|}{2} \\
\hline \multicolumn{4}{|l|}{3} \\
\hline \multicolumn{3}{|c|}{ Hasil Kendali Kesesuaian dengan Standar } & $\ldots$ dari _ \\
\hline \multirow{2}{*}{\multicolumn{2}{|c|}{$\begin{array}{l}\text { Dicek oleh: [nama orang yang } \\
\text { memeriksa] } \\
\text { Hasil Pemeriksaan: Sesuai/Tidak } \\
\text { Sesuai }\end{array}$}} & \multicolumn{2}{|l|}{ Tanggal pengisian } \\
\hline & & $\begin{array}{l}\text { Tanggal } \\
\text { Pemeriksaaan }\end{array}$ & \\
\hline
\end{tabular}

Pada bagian yang diberi warna hijau, tuliskan nomor kode formulir yang akan UKM Anda tetapkan untuk proses kendali Standar Bahan Baku / Alat Kerja. Untuk mempermudah, saran kami beri nomor kode 1.1, bila kemudian UKM Anda mengembangkan formulir baru, lanjutkan penomoran/kode menjadi 1.2, 1.3 dan seterusnya. 


\section{Langkah 2}

\begin{tabular}{|c|c|c|c|}
\hline \multicolumn{2}{|c|}{ Nomor Formulir : 1.1} & \multicolumn{2}{|c|}{ Diisi oleh $\quad$ : [nama yang mengisi] } \\
\hline $\begin{array}{l}\text { No. } \\
\text { Urut }\end{array}$ & $\begin{array}{l}\text { Bahan Baku/ Alat } \\
\text { Kerja }\end{array}$ & Standar Kualitas/Spesifikasi & Terpenuhi \\
\hline \multicolumn{4}{|l|}{1} \\
\hline \multicolumn{4}{|l|}{2} \\
\hline \multicolumn{4}{|l|}{3} \\
\hline \multicolumn{3}{|c|}{ Hasil Kendali Kesesuaian dengan Standar } & _ dari _ \\
\hline \multirow{2}{*}{\multicolumn{2}{|c|}{$\begin{array}{l}\text { Dicek oleh: [nama orang yang } \\
\text { memeriksa] } \\
\text { Hasil Pemeriksaan: Sesuai/Tidak } \\
\text { Sesuai }\end{array}$}} & \multicolumn{2}{|l|}{ Tanggal pengisian } \\
\hline & & $\begin{array}{l}\text { Tanggal } \\
\text { Pemeriksaaan }\end{array}$ & \\
\hline
\end{tabular}

Pada bagian ini yang sekarang diwarnai hijau, sebaiknya diisi oleh orang/staf UKM Anda yang tugasnya berhubungan langsung dengan pengadaan Bahan Baku / Pemeliharaan Alat Kerja. Bisa jadi orangnya bukan 1, tetapi harus jelas siapa saja yang bertanggung jawab untuk mengisi lembar ini.

\section{Langkah 3}

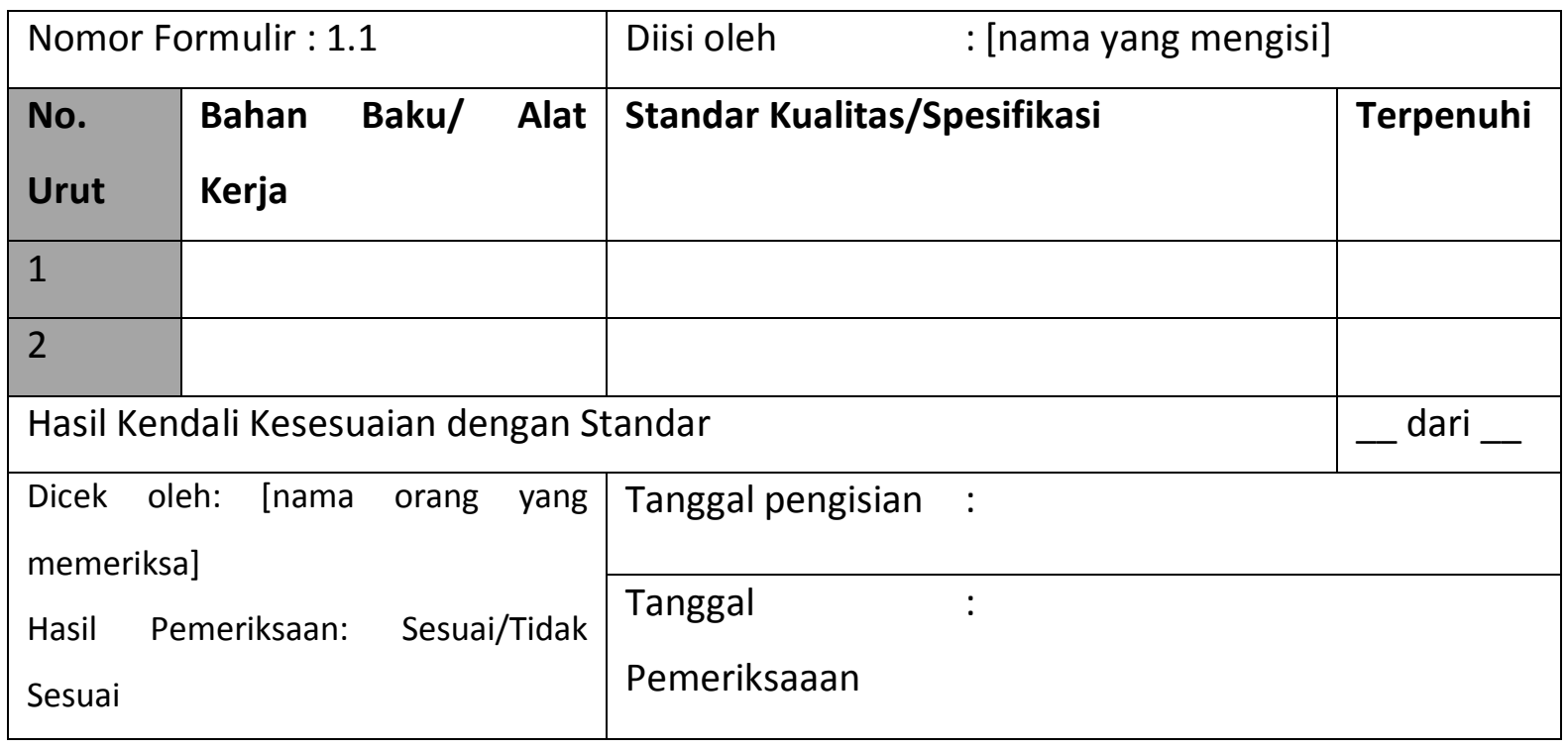

Pada bagian ini yang sekarang diwarnai hijau, merupakan bagian yang diisi dengan nomor urut Bahan Baku / Alat Kerja. Jumlah nomor urut tergantung berapa banyak Bahan Baku / Alat Kerja yang tercantum di daftar/ Standar Bahan Baku / Alat Kerja yang sudah Anda tuliskan 
sebelumnya. Tambahkan sesuai dengan jumlah dan urutan Bahan Baku / Alat Kerja di daftar Anda.

\section{Langkah 4}

\begin{tabular}{|c|c|c|c|}
\hline \multicolumn{2}{|c|}{ Nomor Formulir : 1.1} & \multicolumn{2}{|c|}{ Diisi oleh $\quad$ : [nama yang mengisi] } \\
\hline $\begin{array}{l}\text { No. } \\
\text { Urut }\end{array}$ & $\begin{array}{l}\text { Bahan Baku/ Alat } \\
\text { Kerja }\end{array}$ & Standar Kualitas/Spesifikasi & Terpenuhi \\
\hline \multicolumn{4}{|l|}{1} \\
\hline \multicolumn{4}{|l|}{2} \\
\hline \multicolumn{3}{|c|}{ Hasil Kendali Kesesuaian dengan Standar } & _ dari _ \\
\hline \multirow{2}{*}{\multicolumn{2}{|c|}{$\begin{array}{l}\text { Dicek oleh: [nama orang yang } \\
\text { memeriksa] } \\
\text { Hasil Pemeriksaan: Sesuai/Tidak } \\
\text { Sesuai }\end{array}$}} & \multicolumn{2}{|l|}{ Tanggal pengisian } \\
\hline & & $\begin{array}{l}\text { Tanggal } \\
\text { Pemeriksaaan }\end{array}$ & \\
\hline
\end{tabular}

Pada bagian ini yang sekarang diwarnai hijau, merupakan bagian yang diisi nama-nama/daftar bahan baku sesuai yang sudah Anda tulis di Standar Bahan Baku / Alat Kerja. Tambahkan baris sesuai dengan jumlah Bahan Baku / Alat Kerja, sampai semuanya terdaftar di form ini

\section{Langkah 5}

\begin{tabular}{|c|c|c|c|}
\hline \multicolumn{2}{|c|}{ Nomor Formulir : 1.1} & \multicolumn{2}{|c|}{ Diisi oleh $\quad$ : [nama yang mengisi] } \\
\hline $\begin{array}{l}\text { No. } \\
\text { Urut }\end{array}$ & $\begin{array}{l}\text { Bahan Baku/ Alat } \\
\text { Kerja }\end{array}$ & Standar Kualitas/Spesifikasi & Terpenuhi \\
\hline \multicolumn{4}{|l|}{1} \\
\hline \multicolumn{4}{|l|}{2} \\
\hline \multicolumn{4}{|l|}{3} \\
\hline \multicolumn{3}{|c|}{ Hasil Kendali Kesesuaian dengan Standar } & _ dari _ \\
\hline \multirow{2}{*}{\multicolumn{2}{|c|}{$\begin{array}{l}\text { Dicek oleh: [nama orang yang } \\
\text { memeriksa] } \\
\text { Hasil Pemeriksaan: Sesuai/Tidak } \\
\text { Sesuai }\end{array}$}} & \multicolumn{2}{|l|}{ Tanggal pengisian : } \\
\hline & & $\begin{array}{l}\text { Tanggal } \\
\text { Pemeriksaaan }\end{array}$ & \\
\hline
\end{tabular}

Pada bagian ini yang sekarang diwarnai hijau, merupakan bagian yang standar kualitas / spesifikasi Bahan Baku / Alat Kerja yang sudah Anda tuliskan di Standar Bahan Baku / Alat Kerja. Biasanya di bagian ini tertulis jumlah, spesifikasi dan kondisi standar ideal atau minimal yang dibutuhkan untuk hasilkan produk yang berkualitas. 


\section{Langkah 6}

\begin{tabular}{|c|c|c|c|}
\hline \multicolumn{2}{|c|}{ Nomor Formulir : 1.1} & \multicolumn{2}{|c|}{ Diisi oleh $\quad$ : [nama yang mengisi] } \\
\hline $\begin{array}{l}\text { No. } \\
\text { Urut }\end{array}$ & $\begin{array}{l}\text { Bahan Baku/ Alat } \\
\text { Kerja }\end{array}$ & Standar Kualitas/Spesifikasi & Terpenuhi \\
\hline \multicolumn{4}{|l|}{1} \\
\hline \multicolumn{4}{|l|}{2} \\
\hline \multicolumn{3}{|c|}{ Hasil Kendali Kesesuaian dengan Standar } & _ dari _ \\
\hline \multirow{2}{*}{\multicolumn{2}{|c|}{$\begin{array}{l}\text { Dicek oleh: [nama orang yang } \\
\text { memeriksa] } \\
\text { Hasil Pemeriksaan: Sesuai/Tidak } \\
\text { Sesuai }\end{array}$}} & \multicolumn{2}{|l|}{ Tanggal pengisian } \\
\hline & & $\begin{array}{l}\text { Tanggal } \\
\text { Pemeriksaaan }\end{array}$ & \\
\hline
\end{tabular}

Pada bagian ini yang sekarang diwarnai hijau, merupakan bagian di mana orang yang mengisi harus memberi tanda apakah Bahan Baku / Alat Kerja yang ia periksa/sekarang ada di hadapannya, sudah memenuhi Standar Kualitas. Beri tanda $\checkmark$ bila memenuhi Standar Bahan Baku / Alat Kerja yang sudah Anda tuliskan sebelumnya. Beri tanda? $\boldsymbol{X}$ bila tidak memenuhi.

\section{Langkah 7}

\begin{tabular}{|c|c|c|c|}
\hline \multicolumn{2}{|c|}{ Nomor Formulir : 1.1} & \multicolumn{2}{|c|}{ Diisi oleh $\quad$ : [nama yang mengisi] } \\
\hline $\begin{array}{l}\text { No. } \\
\text { Urut }\end{array}$ & $\begin{array}{l}\text { Bahan Baku/ Alat } \\
\text { Kerja }\end{array}$ & Standar Kualitas/Spesifikasi & Terpenuhi \\
\hline 1 & & & $\checkmark$ \\
\hline 2 & & & $\sqrt{ }$ \\
\hline 3 & & & $x$ \\
\hline \multicolumn{3}{|c|}{ Hasil Kendali Kesesuaian dengan Standar } & _ dari _ \\
\hline \multirow{2}{*}{\multicolumn{2}{|c|}{$\begin{array}{l}\text { Dicek oleh: [nama orang yang } \\
\text { memeriksa] } \\
\text { Hasil Pemeriksaan: Sesuai/Tidak } \\
\text { Sesuai }\end{array}$}} & \multicolumn{2}{|l|}{ Tanggal pengisian : } \\
\hline & & \multicolumn{2}{|l|}{$\begin{array}{l}\text { Tanggal : } \\
\text { Pemeriksaaan }\end{array}$} \\
\hline
\end{tabular}


Pada bagian ini yang sekarang diwarnai hijau, merupakan bagian di mana orang yang mengisi harus menghitung, ada berapa tanda $\checkmark$ dari keseluruhan jumlah Bahan Baku yang terdaftar. Dalam contoh ini misalnya, 2 dari 3.

\section{Langkah 8}

\begin{tabular}{|c|c|c|c|}
\hline \multicolumn{2}{|c|}{ Nomor Formulir : 1.1} & \multicolumn{2}{|c|}{ Diisi oleh $\quad$ : [nama yang mengisi] } \\
\hline $\begin{array}{l}\text { No. } \\
\text { Urut }\end{array}$ & $\begin{array}{l}\text { Bahan Baku/ Alat } \\
\text { Kerja }\end{array}$ & Standar Kualitas/Spesifikasi & Terpenuhi \\
\hline 1 & & & $\checkmark$ \\
\hline 2 & & & $\checkmark$ \\
\hline 3 & & & $x$ \\
\hline \multicolumn{3}{|c|}{ Hasil Kendali Kesesuaian dengan Standar } & _ dari _ \\
\hline \multicolumn{2}{|c|}{$\begin{array}{l}\text { Dicek oleh: [nama orang yang } \\
\text { memeriksa] }\end{array}$} & \multicolumn{2}{|l|}{ Tanggal pengisian } \\
\hline \multicolumn{2}{|c|}{$\begin{array}{l}\text { Hasil Pemeriksaan: Sesuai/Tidak } \\
\text { Sesuai }\end{array}$} & $\begin{array}{l}\text { Tanggal } \\
\text { Pemeriksaaan }\end{array}$ & : \\
\hline
\end{tabular}

Pada bagian ini yang sekarang diwarnai hijau, merupakan bagian di mana ada orang (selain yang mengisi) yang bertanggung jawab untuk memeriksa apakah formulir isian ini telah diisi dengan secara sesuai (antara isian dengan kondisi Bahan Baku / Alat Kerja yang sebenarnya). Yang melakukan pemeriksaan sebaiknya adalah seseorang yang menjadi atasan dari orang yang bertanggung jawab langsung atas pengadaan bahan baku / pemeliharaan alat kerja.

\section{Langkah 9}

\begin{tabular}{|l|l|l|l|}
\hline \multicolumn{2}{|l|}{ Nomor Formulir : 1.1 } & Diisi oleh : [nama yang mengisi] \\
\hline Urut & $\begin{array}{l}\text { Kahan Baku/ Alat } \\
\text { Kerja }\end{array}$ & Standar Kualitas/Spesifikasi & Terpenuhi \\
\hline 1 & & & $\checkmark$ \\
\hline 2 & & & $\checkmark$ \\
\hline 3 & & $X$ \\
\hline Hasil Kendali Kesesuaian dengan Standar & - dari _ \\
\hline $\begin{array}{l}\text { Dicek oleh: [nama orang yang } \\
\text { memeriksa] }\end{array}$ & Tanggal pengisian : \\
\hline
\end{tabular}




\begin{tabular}{|l|l|}
\hline Hasil Pemeriksaan: Sesuai/Tidak & Tanggal : \\
Sesuai & Pemeriksaaan \\
\hline
\end{tabular}

Pada bagian ini yang sekarang diwarnai hijau, merupakan bagian diisi dengan tanggal formulir ini diisi untuk memeriksa Bahan Baku / Alat Kerja

Langkah 10

\begin{tabular}{|c|c|c|c|}
\hline \multicolumn{2}{|c|}{ Nomor Formulir : 1.1} & \multicolumn{2}{|c|}{ Diisi oleh $\quad$ : [nama yang mengisi] } \\
\hline $\begin{array}{l}\text { No. } \\
\text { Urut }\end{array}$ & $\begin{array}{l}\text { Bahan Baku/ Alat } \\
\text { Kerja }\end{array}$ & Standar Kualitas/Spesifikasi & Terpenuhi \\
\hline 1 & & & $\checkmark$ \\
\hline 2 & & & $\checkmark$ \\
\hline 3 & & & $x$ \\
\hline \multicolumn{3}{|c|}{ Hasil Kendali Kesesuaian dengan Standar } & _ dari __ \\
\hline \multirow{2}{*}{\multicolumn{2}{|c|}{$\begin{array}{l}\text { Dicek oleh: [nama orang yang } \\
\text { memeriksa] } \\
\text { Hasil Pemeriksaan: Sesuai/Tidak } \\
\text { Sesuai }\end{array}$}} & \multicolumn{2}{|l|}{ Tanggal pengisian } \\
\hline & & \multicolumn{2}{|l|}{$\begin{array}{l}\text { Tanggal : } \\
\text { Pemeriksaaan }\end{array}$} \\
\hline
\end{tabular}

Pada bagian ini yang sekarang diwarnai hijau, merupakan bagian diisi dengan tanggal formulir ini diperiksa oleh Pengecek.

Formulir ini harus dibiasakan untuk diisi secara teratur, misalnya:

- Formulir Kendali Bahan Baku / Alat Kerja, diisi setiap sebelum proses produksi atau kegiatan kerja dimulai

- Lalu dicek segera sebelum proses produksi atau kegiatan kerja dimulai

Formulir yang sudah terisi, sebaiknya diarsipkan/disimpan sesuai dengan tanggal pengisian dan/ disatukan dengan Formulir Kendali Proses Produksi / Langkah Kerja dan Formulir Kendali Hasil Akhir utk periode produksi / kegiatan jasa yang sama (hari yang sama, minggu yang sama atau bulan yang sama)

Selamat! Ini langkah tambahan agar UKM Anda memiliki kualitas yang baik dan konsisten. Setelah mengerjakan Modul ini, Anda seharusnya sudah:

- memahami apa itu Manajemen Mutu Bahan Baku / Alat Produksi 
○ Memahami langkah-langkah pengisian Formulir Kendali Mutu Bahan Baku / Alat

\section{Produksi}

Bila ada yang belum anda pahami dan, mohon tandai dengan ' $x$ 'di daftar di atas. Tuliskan di kotak bawah, hal-hal yang masih Anda anggap kurang jelas atau Anda ingin ketahui lebih lanjut:

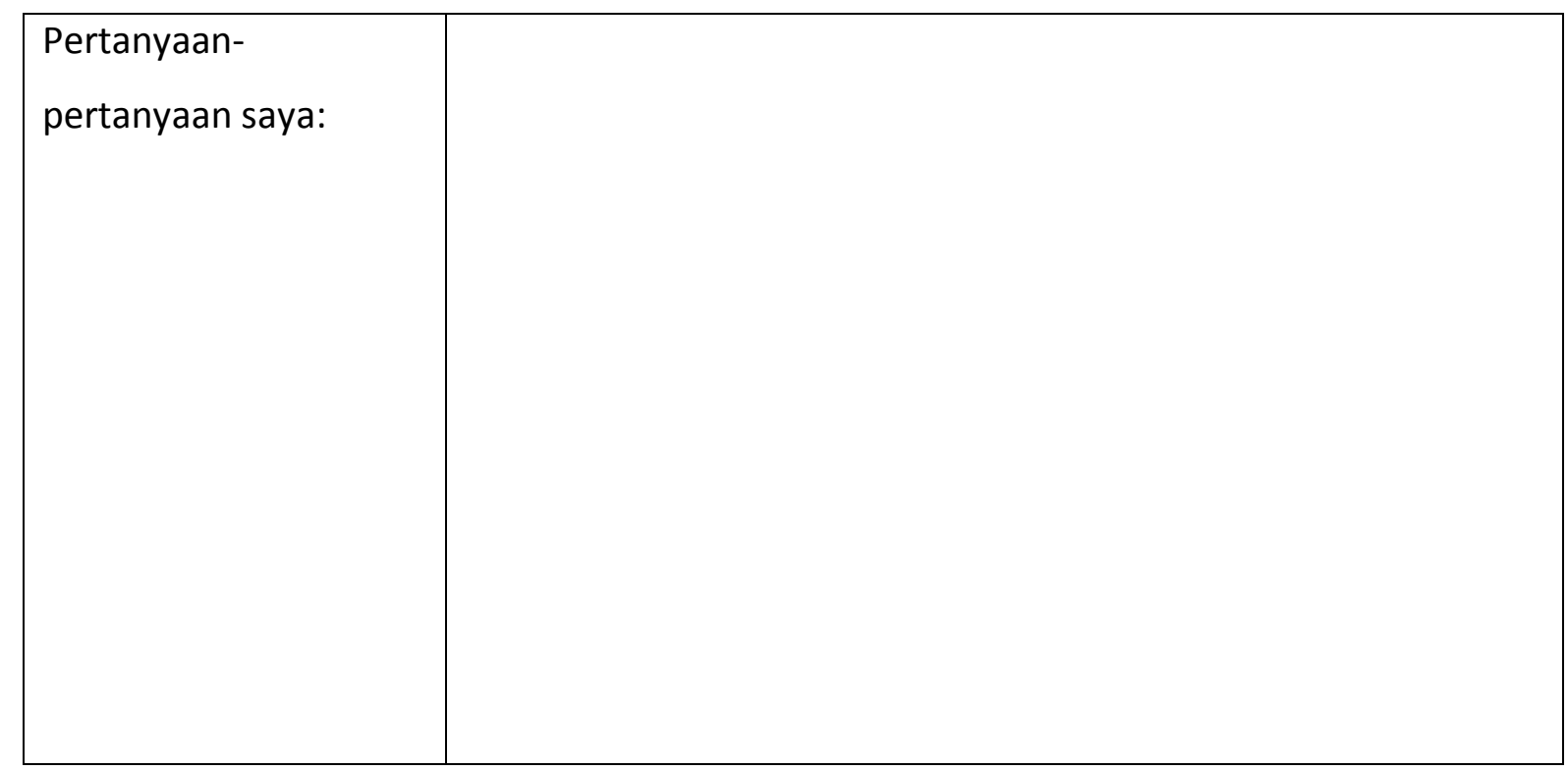

Lalu hubungi TIM Pendamping terdekat.

Anda siap untuk melanjutkan ke Modul selanjutnya! 


\section{Modul}

\section{Sistem Manajemen Mutu Hasil Akhir}

\section{Penjelasan Umum Modul}

\section{Modul Sistem Manajemen Mutu Mutu Hasil Akhir}

\subsubsection{Pemahaman Umum Manajemen Mutu Mutu Hasil Akhir}

\subsubsection{Manfaat Manajemen Mutu Mutu Hasil Akhir}

\subsubsection{Langkah - Langkah melakukan Manajemen Mutu Mutu Hasil Akhir}

Output:

- Peserta memahami apa itu Manajemen Mutu Mutu Hasil Akhir

- Peserta memahami manfaat Manajemen Mutu Mutu Hasil Akhir

- Peserta memahami langkah-langkah umum menuliskan dan melakukan Manajemen Mutu Mutu Hasil Akhir

Estimasi durasi untuk mengerjakan secara mandiri $\quad$ : 2-4 jam

Dukungan yang dibutuhkan

- Pendampingan Mentor untuk penulisan langkah-langkah Manajemen Mutu Mutu Hasil Akhir

- Audit panduan Manajemen Mutu Proses Mutu Hasil Akhir

- Membahas bersama UKM lain, Manajemen Mutu Mutu Hasil Akhir masing-masing 
Ketika Anda memulai modul ini, seharusnya Anda sudah membaca dan mengerjakan modul berikut:

1. Merumuskan Standar Produk/Jasa

2. Menyusun Standar Proses Produksi / Langkah Kerja

3. Menyusun Standar Bahan Baku / Alat Kerja

4. Manajemen Mutu

Jika belum, silakan Anda baca dan kerjakan dahulu modul yang masih terlewat.

Jika sudah, semua yang Anda baca dan kerjakan di modul terdahulu akan kita gunakan pada modul ini dan selanjutnya.

Setelah Anda memahami konsep dasar Manajemen Mutu dan melihat berbagai contoh formulirnya, kita akan fokus mengembangkan Manajemen Mutu Proses Produksi / Langkah Kerja.

\section{Contoh Pembuatan \& Pengisian Formulir Kendali Mutu Hasil Akhir}

\section{Langkah 1}

\begin{tabular}{|c|c|c|c|}
\hline \multicolumn{2}{|c|}{ Nomor Formulir : 3.1} & \multicolumn{2}{|c|}{ [nama yang mengisi] } \\
\hline No.Urut & Kriteria Kualitas & Standar & Terpenuhi \\
\hline 1 & Warna & & \\
\hline 2 & Ukuran & & \\
\hline 3 & Berat & & \\
\hline 4 & Kerapihan & & \\
\hline \multicolumn{3}{|c|}{ Hasil Kendali Kesesuaian dengan Standar } & _ dari __ \\
\hline \multicolumn{2}{|c|}{$\begin{array}{l}\text { Dicek oleh: [nama orang yang } \\
\text { memeriksa] }\end{array}$} & \multicolumn{2}{|l|}{$\begin{array}{l}\text { Tanggal } \\
\text { pengisian }\end{array}$} \\
\hline \multicolumn{2}{|c|}{$\begin{array}{l}\text { Hasil Pemeriksaan: Sesuai/Tidak } \\
\text { Sesuai }\end{array}$} & \multicolumn{2}{|l|}{$\begin{array}{l}\text { Tanggal } \\
\text { Pemeriksaaan }\end{array}$} \\
\hline
\end{tabular}

Pada bagian yang diberi warna hijau, tuliskan nomor kode formulir yang akan UKM Anda tetapkan untuk proses kendali Standar Proses Produksi / Langkah Kerja. Untuk mempermudah, saran kami beri nomor kode 1.1, bila kemudian UKM Anda mengembangkan formulir baru, lanjutkan penomoran/kode menjadi 1.2, 1.3 dan seterusnya. 


\section{Langkah 2}

\begin{tabular}{|l|l|l|l|}
\hline \multicolumn{2}{|l|}{ Nomor Formulir : 3.1 } & Diisi oleh : [nama yang mengisi] & Terpenuhi \\
\hline No.Urut & Kriteria Kualitas & Standar & \\
\hline 1 & Warna & & \\
\hline 3 & Ukuran & & \\
\hline 4 & Kerat & & — dari - \\
\hline Hasil Kendali Kesesuaian dengan Standar & \\
\hline $\begin{array}{l}\text { Dicek oleh: [nama orang yang } \\
\text { memeriksa] }\end{array}$ & $\begin{array}{l}\text { Tanggal } \\
\text { Hasil Pemeriksaan: Sesuai/Tidak }\end{array}$ & $\begin{array}{l}\text { Tanggal } \\
\text { Sesuai }\end{array}$ & Pemeriksaan : \\
\hline
\end{tabular}

Pada bagian ini yang sekarang diwarnai hijau, sebaiknya diisi oleh orang/staf UKM Anda yang tugasnya berhubungan langsung dengan proses pengiriman atau penjualan produk. Bisa jadi orangnya bukan hanya 1 orang, tetapi harus jelas siapa saja yang bertanggung jawab untuk mengisi lembar ini bahkan bila bergantian.

\section{Langkah 3}

\begin{tabular}{|l|l|l|l|}
\hline \multicolumn{2}{|l|}{ Nomor Formulir : 3.1 } & Diisi oleh : [nama yang mengisi] & Terpenuhi \\
\hline No.Urut & Kriteria Kualitas & Standar & \\
\hline 2 & Warna & & \\
\hline 3 & Ukuran & & \\
\hline 4 & Berat & & \\
\hline Hasil Kendali Kesesuaian dengan Standar & dari \\
\hline $\begin{array}{l}\text { Dicek oleh: [nama orang yang } \\
\text { memeriksa] }\end{array}$ & $\begin{array}{l}\text { Tanggal } \\
\text { Hasil Pemeriksaan: Sesuai/Tidak } \\
\text { Sesuai }\end{array}$ & $\begin{array}{l}\text { Tanggal } \\
\text { pengian }\end{array}$ \\
\hline
\end{tabular}

Pada bagian ini yang sekarang diwarnai hijau, merupakan bagian yang diisi dengan nomor urut Kriteria Kualitas. Jumlah nomor urut tergantung berapa banyak Kriteria Kualitas yang 
tercantum di daftar Standar Kualitas Produk / Jasa yang sudah Anda tuliskan sebelumnya. Tambahkan sesuai dengan jumlah dan urutan Standar Kualitas Produk / Jasa di daftar Anda.

\section{Langkah 4}

\begin{tabular}{|l|l|l|l|}
\hline \multicolumn{2}{|l|}{ Nomor Formulir : 3.1} & Diisi oleh : [nama yang mengisi] & Terpenuhi \\
\hline No.Urut & Kriteria Kualitas & Standar & \\
\hline 2 & Warna & & \\
\hline 3 & Ukuran & & \\
\hline 4 & Berat & Kerapihan & _ dari _ \\
\hline Hasil Kendali Kesesuaian dengan Standar & \\
\hline $\begin{array}{l}\text { Dicek oleh: [nama orang yang } \\
\text { memeriksa] }\end{array}$ & $\begin{array}{l}\text { Tanggal } \\
\text { Hasil Pemeriksaan: Sesuai/Tidak } \\
\text { Sesuai }\end{array}$ & $\begin{array}{l}\text { Tanggal } \\
\text { pengisian }\end{array}$ & \\
\hline
\end{tabular}

Pada bagian ini yang sekarang diwarnai hijau, merupakan bagian yang diisi Kriteria Kualitas sesuai yang sudah Anda tulis di Standar Produk Akhir / Jasa. Tambahkan baris sesuai dengan jumlah Kriteria Kualitas, sampai semuanya terdaftar di formulir ini

\section{Langkah 5}

\begin{tabular}{|c|c|c|c|c|}
\hline \multicolumn{2}{|c|}{ Nomor Formulir : 3.1} & \multicolumn{3}{|c|}{ [nama yang mengisi] } \\
\hline No.Urut & Kriteria Kualitas & Standar & & Terpenuhi \\
\hline 1 & Warna & & & \\
\hline 2 & Ukuran & & & \\
\hline 3 & Berat & & & \\
\hline 4 & Kerapihan & & & \\
\hline \multicolumn{4}{|c|}{ Hasil Kendali Kesesuaian dengan Standar } & $\ldots$ dari __ \\
\hline \multicolumn{2}{|c|}{$\begin{array}{l}\text { Dicek oleh: [nama orang yang } \\
\text { memeriksa] }\end{array}$} & \multicolumn{3}{|l|}{$\begin{array}{l}\text { Tanggal } \\
\text { pengisian }\end{array}$} \\
\hline \multicolumn{2}{|c|}{$\begin{array}{l}\text { Hasil Pemeriksaan: Sesuai/Tidak } \\
\text { Sesuai }\end{array}$} & $\begin{array}{l}\text { Tanggal } \\
\text { Pemeriksaaan }\end{array}$ & \\
\hline
\end{tabular}


Pada bagian ini yang sekarang diwarnai hijau, merupakan isian mengenai yang rincian atau cara mengukur kriteria kualitas (misal, kerapihan $1 \mathrm{~s} / \mathrm{d}$ 10, warna merah grade 3 , dst) yang sudah Anda tuliskan di Standar Kualitas Produk.

\section{Langkah 6}

\begin{tabular}{|c|c|c|c|c|}
\hline \multicolumn{2}{|c|}{ Nomor Formulir : 3.1} & \multicolumn{3}{|c|}{ Diisi oleh $\quad$ : [nama yang mengisi] } \\
\hline No.Urut & Kriteria Kualitas & Standar & & Terpenuhi \\
\hline 1 & Warna & & & $\checkmark$ \\
\hline 2 & Ukuran & & & $\checkmark$ \\
\hline 3 & Berat & & & $\checkmark$ \\
\hline 4 & Kerapihan & & & $x$ \\
\hline \multicolumn{4}{|c|}{ Hasil Kendali Kesesuaian dengan Standar } & _ dari _ \\
\hline \multicolumn{2}{|c|}{$\begin{array}{l}\text { Dicek oleh: [nama orang yang } \\
\text { memeriksa] }\end{array}$} & \multicolumn{3}{|l|}{$\begin{array}{l}\text { Tanggal } \\
\text { pengisian }\end{array}$} \\
\hline \multicolumn{2}{|c|}{$\begin{array}{l}\text { Hasil Pemeriksaan: Sesuai/Tidak } \\
\text { Sesuai }\end{array}$} & $\begin{array}{l}\text { Tanggal } \\
\text { Pemeriksaaan }\end{array}$ & \multicolumn{2}{|c|}{ : } \\
\hline
\end{tabular}

Pada bagian ini yang sekarang diwarnai hijau, merupakan bagian di mana orang yang mengisi harus memberi tanda apakah Produk / Jasa yang ia akan tawarkan kepada konsumen, sudah memenuhi Standar Kualitas yang diharapkan. Beri tanda $\checkmark$ bila memenuhi Standar Produk / Jasa yang sudah Anda tuliskan sebelumnya. Beri tanda? $\boldsymbol{X}$ bila tidak memenuhi.

\section{Langkah 7}

\begin{tabular}{|l|l|l|l|}
\hline \multicolumn{2}{|l|}{ Nomor Formulir : 3.1 } & Diisi oleh : [nama yang mengisi] \\
\hline No.Urut & Kriteria Kualitas & Standar & Terpenuhi \\
\hline 1 & Warna & & $\checkmark$ \\
\hline 3 & Ukuran & & $\checkmark$ \\
\hline 4 & Berat & & $\checkmark$ \\
\hline Hasil Kendali Kesesuaian dengan Standar & $X$ \\
\hline $\begin{array}{l}\text { Dicek oleh: [nama orang yang } \\
\text { memeriksa] }\end{array}$ & $\begin{array}{l}\text { Tanggal } \\
\text { pengisian }\end{array}$ & \\
\hline
\end{tabular}




\begin{tabular}{|c|c|}
\hline $\begin{array}{l}\text { Hasil Pemeriksaan: Sesuai/Tidak } \\
\text { Sesuai }\end{array}$ & $\begin{array}{l}\text { Tanggal } \\
\text { Pemeriksaaan }\end{array}$ \\
\hline
\end{tabular}

Pada bagian ini yang sekarang diwarnai hijau, merupakan bagian di mana orang yang mengisi harus menghitung, ada berapa tanda $\checkmark$ dari keseluruhan Kriteria Kualitas yang terdaftar. Dalam contoh ini misalnya, 3 dari 4.

\section{Langkah 8}

\begin{tabular}{|l|l|l|l|}
\hline \multicolumn{2}{|l|}{ Nomor Formulir : 3.1 } & Diisi oleh : [nama yang mengisi] \\
\hline No.Urut & Kriteria Kualitas & Standar & Terpenuhi \\
\hline 1 & Warna & & $\checkmark$ \\
\hline 3 & Ukuran & & $\checkmark$ \\
\hline 4 & Berat & & $\boldsymbol{X}$ \\
\hline Hasil Kendali Kesesuaian dengan Standar & - dari \\
\hline $\begin{array}{l}\text { Dicek oleh: [nama orang yang } \\
\text { memeriksa] } \\
\text { Hasil Pemeriksaan: Sesuai/Tidak } \\
\text { Sesuai }\end{array}$ & \begin{tabular}{l} 
Tanggal \\
\cline { 2 - 4 }
\end{tabular} & $\begin{array}{l}\text { Tanggal } \\
\text { Pengisian }\end{array}$ \\
\hline
\end{tabular}

Pada bagian ini yang sekarang diwarnai hijau, merupakan bagian di mana ada orang (selain yang mengisi) yang bertanggung jawab untuk memeriksa apakah formulir isian ini telah diisi dengan secara sesuai (antara isian dengan kondisi Produk Akhir / Jasa yang sebenarnya). Yang melakukan pemeriksaan sebaiknya adalah seseorang yang menjadi atasan dari orang yang bertanggung jawab langsung atas Produk

\section{Langkah 9}

\begin{tabular}{|l|l|l|l|}
\hline \multicolumn{2}{|l|}{ Nomor Formulir : 3.1} & Diisi oleh : [nama yang mengisi] \\
\hline $\begin{array}{l}\text { No. } \\
\text { Urut }\end{array}$ & Kriteria Kualitas & Standar & Terpenuhi \\
\hline 1 & Warna & & $\checkmark$ \\
\hline 2 & Ukuran & & $\checkmark$ \\
\hline 3 & Berat & & $\checkmark$ \\
\hline 4 & Kerapihan & & $x$ \\
\hline Hasil Kendali Kesesuaian dengan Standar & - dari \\
\hline
\end{tabular}




\begin{tabular}{|l|ll|}
\hline Dicek oleh: [nama orang yang & Tanggal & $:$ \\
memeriksa] & pengisian & \\
Hasil Pemeriksaan: Sesuai/Tidak & Tanggal & $:$ \\
Sesuai & Pemeriksaaan & \\
\hline
\end{tabular}

Pada bagian ini yang sekarang diwarnai hijau, merupakan bagian diisi dengan tanggal formulir ini diisi untuk memeriksa Produk / Jasa Akhir

\section{Langkah 10}

\begin{tabular}{|c|c|c|c|c|}
\hline \multicolumn{2}{|c|}{ Nomor Formulir : 3.1} & \multicolumn{3}{|c|}{ : [nama yang mengisi] } \\
\hline No.Urut & Kriteria Kualitas & Standar & & Terpenuhi \\
\hline 1 & Warna & & & $\checkmark$ \\
\hline 2 & Ukuran & & & $\checkmark$ \\
\hline 3 & Berat & & & $\checkmark$ \\
\hline 4 & Kerapihan & & & $x$ \\
\hline \multicolumn{4}{|c|}{ Hasil Kendali Kesesuaian dengan Standar } & $\ldots$ dari __ \\
\hline \multicolumn{2}{|c|}{$\begin{array}{l}\text { Dicek oleh: [nama orang yang } \\
\text { memeriksa] }\end{array}$} & \multicolumn{3}{|l|}{$\begin{array}{l}\text { Tanggal } \\
\text { pengisian }\end{array}$} \\
\hline \multicolumn{2}{|c|}{$\begin{array}{l}\text { Hasil Pemeriksaan: Sesuai/Tidak } \\
\text { Sesuai }\end{array}$} & $\begin{array}{l}\text { Tanggal } \\
\text { Pemeriksaaan }\end{array}$ & \multicolumn{2}{|c|}{ : } \\
\hline
\end{tabular}

Pada bagian ini yang sekarang diwarnai hijau, merupakan bagian diisi dengan tanggal formulir ini diperiksa oleh Pengecek.

Formulir ini harus dibiasakan untuk diisi secara teratur, misalnya:

- Formulir Kendali Proses Produksi / Langkah Kerja ini, segera setelah proses produksi selesai atau setelah Jasa dinikmati pelanggan

Khusus untuk UKM Jasa, penilaian bisa jadi perlu melibatkan konsumen yang menikmati Jasa. Formulir yang sudah terisi, sebaiknya diarsipkan/disimpan sesuai dengan tanggal pengisian dan/ disatukan dengan Formulir Kendali Bahan Baku / Alat Produksi dan Formulir Kendali 
Proses Produksi utk periode produksi / kegiatan jasa yang sama (hari yang sama, minggu yang sama atau bulan yang sama)

71 Kemendagri - sylabus - 2018 
Selamat! Ini langkah tambahan agar UKM Anda memiliki kualitas yang baik dan konsisten. Setelah mengerjakan Modul ini, Anda seharusnya sudah:

- memahami apa itu Manajemen Kualitas Akhir

- Memahami langkah-langkah pengisian Formulir Kendali Kualitas Akhir

Bila ada yang belum anda pahami dan, mohon tandai dengan ' $x$ 'di daftar di atas. Tuliskan di kotak bawah, hal-hal yang masih Anda anggap kurang jelas atau Anda ingin ketahui lebih lanjut:

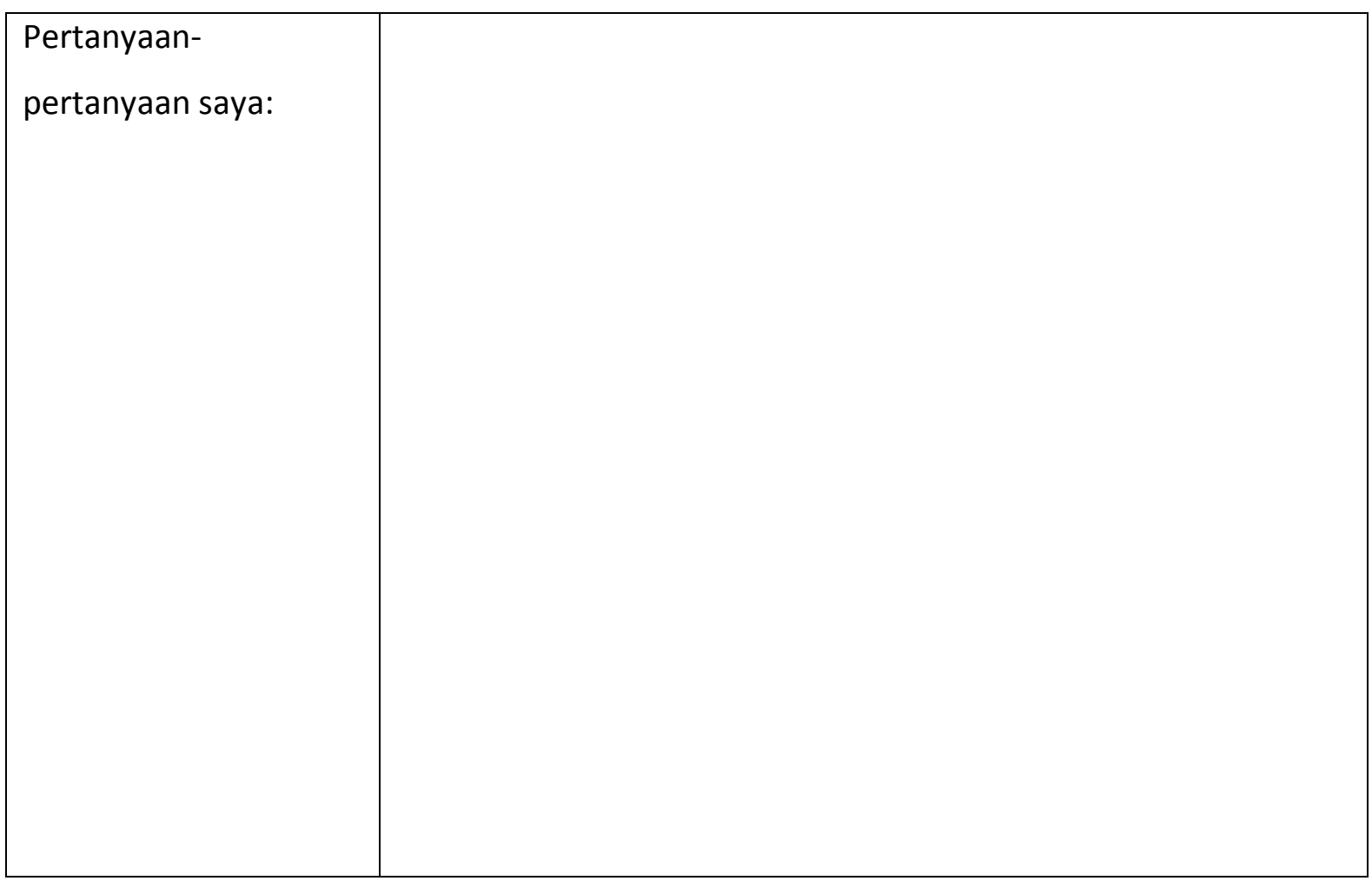

Lalu hubungi TIM Pendamping terdekat.

Anda siap untuk melanjutkan ke Modul selanjutnya! 


\section{Modul I}

\section{Pengurusan dan Pembuatan Badan Usaha}

\section{Penjelasan Umum Modul Pengurusan dan Pembuatan Badan Usaha}

Dalam Modul ini kami akan membahas mengenai pengurusan pendirian Badan Usaha di Indonesia.

Output:

- Peserta memahami jenis-jenis badan usaha yang akan dipilih

- Peserta memahami proses pembuatan badan usaha

- Peserta memahami pihak yang dapat membantu membuat badan usahanya

Estimasi durasi untuk mengerjakan secara mandiri : 1-2 jam

Dukungan yang dibutuhkan

- Pendampingan Notaris atau praktisi untuk membantu melakukan pengurusan pembentukan badan usaha

- Membahas bersama UKM lain yang sejenis sektor usahanya perihal proses badan usaha yang dipilih oleh mereka

10. Modul mengenai Pengurusan dan Pembuatan Dadan Usaha

10. 1 Pengurusan Badan Usaha

10. 1.1 Proses Pembuatan masing-masing Badan Usaha

10.1.1.1 Badan Usaha Non Badan Hukum

10.1.1.2 Badan Usaha berbentuk Badan Hukum

10.2.1 Studi Kasus 


\section{1.1 Proses Pembuatan masing-masing Badan Usaha}

Berikut ini akan diuraikan mengenai proses-proses yang perlu dilalui untuk membuat sebuah badan usaha.

\subsubsection{Badan Usaha Non Badan Hukum}

\section{- Perusahaan Perorangan}

Terhadap kegiatan usaha ini tidak diperlukan sebuah proses hingga terbentuk sebuah badan usaha.

Khusus untuk Usaha Dagang maka dibutuhkan beberapa proses yang diperlukan untuk diterima sebagai sebuah usaha dagang.

1. Perseorangan meminta kepada pihak notaris untuk membuat akta pendirian dari sebuah Usaha Dagang yang pada Pokoknya berisikan Nama Usaha Dagang, Domisili Usaha Dagang, Pemilik Usaha Dagang.

2. Setelah Akta Pendirian Usaha Dagang selesai dibentuk, Perseorangan dapat melakukan pendaftaran Akta tersebut di Pengadilan Tempat Domisili Usaha Dagang dibuat.

3. Kemudian melakukan pendaftaran untuk memintakan Izin Usaha Pedagang Perseorangan kepada Dinas Koperasi dan Usaha Kecil dan Menengah daerah Setempat

4. Melakukan pendaftaran dan permintaan izin sesuai dengan jenis kegiatan usaha yang dilakukan

\section{- Persekutuan Perdata}

Persekutuan Perdata didirikan berdasarkan perjanjian diantara para pendirinya yang merupakan subjek hukum baik Perorangan maupun Badan Hukum, yang dituangkan di dalam Akta Pendirian yang dibuat oleh Notaris.

Proses yang perlu dilakukan cukup membuat perjanjian antara para pendiri yang dapat berisikan hal-hal terkait dengan apa saja yang akan dikerjakan didalam persekutuan, apa saja yang akan dimasukan kedalam persekutuan, bagaimana pembagian keuntungan didalam persekutuan dan sampaikan persekutuan akan dijalankan. 


\section{- Firma}

Firma didirikan berdasarkan persetujuan tertulis diantara para pendirinya dalam bentuk Akta Notaris. Namun, Firma juga dapat dibentuk dengan Akta Bawah Tangan (tidak dibuat dihadapan notaris) dan dianggap tetap sah terhadap Pihak Ketiga.

Berikut ialah proses yang dilakukan apabila dibuat dihadapan Notaris:

1. Para pendiri yang akan melakukan pendirian membuat perjanjian yang nantinya akan disebut sebagai Akta Pendirian.

2. Akta pendirian kemudian dibuat oleh Notaris bersama dengan para pendiri

3. Sesudah Akta Pendirian dibuat, Akta Pendirian tersebut wajib didaftarkan di kepaniteraan Pengadilan Negeri tempat domisili Firma dibentuk.

4. Ikhtisar dari Akta Pendirian juga wajib diumumkan dalam Berita Negara.

5. Melakukan pendaftaran dan permintaan izin sesuai dengan jenis kegiatan usaha yang dilakukan

Tujuan pendaftaran Akta Pendirian agar masyarakat umum atau pihak ketiga yang berkepentingan dapat mengetahui Informasi tentang siapa saja anggota sekutunya, dimana domisili firma tersebut.

\section{- Persekutuan Komanditer (CV)}

CV didirikan berdasarkan persetujuan tertulis diantara para pendirinya dalam bentuk Akta Notaris. Namun, CV juga dapat dibentuk dengan Akta Bawah Tangan (tidak dibuat dihadapan notaris) dan dianggap tetap sah terhadap Pihak Ketiga.

Berikut ialah proses yang dilakukan apabila dibuat dihadapan Notaris:

1. Para pendiri yang akan melakukan pendirian membuat perjanjian yang nantinya akan disebut sebagai Akta Pendirian.

2. Akta pendirian kemudian dibuat oleh Notaris bersama dengan para pendiri

3. Sesudah Akta Pendirian dibuat, Akta Pendirian tersebut wajib didaftarkan di kepaniteraan Pengadilan Negeri tempat domisili CV dibentuk.

4. Ikhtisar dari Akta Pendirian juga wajib diumumkan dalam Berita Negara.

5. Melakukan pendaftaran dan permintaan izin sesaui dengan jenis kegiatan usaha yang dilakukan 
Tujuan pendaftaran Akta Pendirian agar masyarakat umum atau pihak ketiga yang berkepentingan dapat mengetahui Informasi tentang siapa saja anggota sekutunya, dimana domisili CV tersebut.

\subsubsection{Badan Usaha berbentuk Badan Hukum}

\section{- Perseroan Terbatas (PT)}

Untuk mendirikan PT, terdapat beberapa syarat yang harus dipenuhi supaya pendirian Perseroan sah sebagai badan hukum. diantaranya adalah :

1. Pemesanan nama PT dapat dilakukan oleh pendirinya maupun notaris yang dikuasakan melalui Dirjen AHU Kemenkumham. Saat pemesanan nama PT dapat mengajukan maksimal 3 (tiga) calon nama yang nantinya akan mendapat persetujuan dari Dirjen AHU Kemenkumham mengenai nama PT yang dapat digunakan.

2. Pendirian PT didasarkan atas perjanjian yang dibuat oleh para pendirinya (subjek hukum) untuk membentuk suatu Perseroan Terbatas. Subjek hukum disini adalah orang pribadi maupun Badan Hukum (PT, Koperasi dan Yayasan). sehingga dimungkinkan bahwa pendiri PT adalah perorangan dengan perorangan, perorangan dengan badan hukum maupun badan hukum dengan badan hukum.

3. Penyusunan Anggaran Dasar yang menjadi landasan bagi Perseroan Terbatas dalam melakukan kegiatan usahanya dengan bantuan Notaris untuk dituangkan dalam bentuk akta pendirian. Pendirian PT harus dibuat dengan Akta Otentik sebagai syarat untuk disahkan oleh Kementerian Hukum dan Ham.

4. Akta Pendirian juga harus memuat keterangan lainnya yang sekurang-kurangnya memuat :

- Nama lengkap, tempat dan tanggal lahir, pekerjaan, tempat tinggal dan kewarganegaraan pendiri perseorangan (bagi pendiri perorangan) atau nama, tempat kedudukan dan alamat lengkap serta nomor dan tanggal keputusan Menteri mengenai pengesahan badan hukum dari pendiri Perseroan (bagi pendiri yang merupakan badan hukum)

- Nama lengkap, tempat dan tanggal lahir, pekerjaan, tempat tinggal, kewarganegaraan anggota Direksi dan Dewan.Komisaris yang pertama kali diangkat 
- Nama Pemegang daham yang telah mengambil bagian saham, rincian jumlah saham dan nilai nominal saham yang telah ditempatkan dan disetor Akta Pendirian wajib dibuat dalam bahasa indonesia

5. Akta Pendirian yang sudah dibuat, kemudian diajukan kepada Kementerian Hukum dan HAM untuk mendapatkan pengesahan sehingga memperoleh status badan hukum. Apabila pengajuan akan pengesahan mendapat penolakan, maka diberikan kesempatan paling lambat 30 hari kerja untuk membetulkan hal-hal yang menjadi dasar penolakan dari pengesahan tersebut.

\section{- Koperasi}

Dalam proses pembentukan sebuah Koperasi terdapat berbagai tahapan-tahapan yang dilakukan bersama dengan pihak Dinas Koperasi dan Usaha Kecil Menengah.

1. Para pendiri Koperasi perlu memiliki calon anggota sebanyak 20 Orang termasuk dengan para pendiri.

2. Para pendiri beserta dengan calon anggota akan mendapatkan kegiatan penyuluhan terkait dengan pembentukan koperasi dari Dinas Koperasi dan Usaha Kecil Menengah.

3. Telah melaksanakan Rapat Pendirian Koperasi yang didalamnya termuat berita acara rapat pendirian koperasi dan daftar hadir rapat pendirian koperasi

4. Para Pendiri beserta dengan calon anggota membuat Akta Pendirian Koperasi bersama dengan Notaris Terdaftar dan Memiliki Sertifikasi Khusus dibidang Koperasi

5. Surat bukti tersedianya modal yang jumlahnya sekurang-kurangnya sebesar simpanan pokok dan simpanan wajib yang telah dilunasi oleh para pendiri

6. Telah memiliki rencana kegiatan usaha koperasi selama paling sedikit 3 tahun kedepan dan rencana anggaran belanja dan pendapatan koperasi.

7. Telah memiliki Daftar susunan pengurus, pengawas koperasi disertai dengan surat pernyataan tidak mempunyai hubungan keluarga antara pengurus, Daftar sarana kerja Koperasi dan Struktur organisasi Koperasi.

8. Seluruh dokumen tersebut dikirimkan kepada pejabat terkait di Dinas Koperasi dan Usaha Kecil Menengah untuk dilakukan pemeriksaan secara administrasi 
dan substansi serta dilakukan pemeriksaan secara langsung terkait keberadaan koperasi tersebut.

9. Setelah pemeriksaan secara langsung Pihak Kementerian Koperasi dan Usaha Kecil dan Menengah mengeluarkan Surat Keputusan terkait dengan pengesahan dari Koperasi.

10. Apabila terjadi penolakan, pihak pendiri dapat melakukan permintaan ulang terhadap pengesahan akta pendirian koperasi.

11. Bila dalam proses ini koperasi tidak juga mendapatkan pengesahan maka permohonan lanjutan tidak dapat diterima.

Terhadap penyelenggaraan kegiatan usaha berbasis Koperasi membutuhkan hubungan secara langsung dengan pemerintah daerah maupun dinas-dinas terkait yang dapat menyokong pembentukan serta penyelenggaraan koperasi dikemudian hari.

\subsubsection{Studi Kasus}

1. Terhadap jenis badan usaha yang telah anda sudah pilih, coba anda lakukan pemetaan terhadap dokumen-dokumen apa saja yang telah anda miliki dan dokumen apa yang belum anda miliki.

2. Jika memilih Perseroan Terbatas, dapatkah anda mencoba membuat kerangka dasar akta pendirian yang akan anda buat.

\begin{tabular}{|l|l|}
\hline Calon Nama PT & 1. \\
\hline Pemegang Saham & 1. \\
\hline Maksud dan Tujuan PT & \\
\hline Modal Dasar & \\
\hline Nominal Saham & \\
\hline Modal Ditempatkan dan Disetor & \\
\hline Susunan Direksi & 1. \\
\hline Dewan Komisaris & 1. \\
\hline
\end{tabular}


Modul I:

11.UKM Go Digital Modul Media Sosial

Pendahuluan Struktur

11.1. Facebook Fanpage

11.2. Instagram

Tujuan Modul

1. Peserta memiliki keahlian dasar dalam mengelola Page Facebook

2. Peserta memiliki keahlian dasar dalam mengelola akun Instagram 


\section{Facebook}

Facebook adalah jejaring sosial terbesar di dunia, dengan lebih dari 1,5 miliar pengguna yang aktif tiap bulannya. Di Indonesia sendiri, pengguna aktif Facebook ada lebih dari 100 juta tiap bulannya. Agar usaha Anda bisa lebih dikenal banyak orang, Facebook adalah layanan yang sangat tepat untuk digunakan.

\section{Akun Facebook vs Facebook Page}

Akun Facebook pada dasarnya didesain untuk pengguna pribadi untuk berjejaring dengan keluarga maupun teman. Untuk memenuhi kebutuhan selebritis, perusahaan, merek, maupun UKM, Facebook menyediakan fitur Page di mana pengguna biasa bisa memberikan "suka/like" kepada Page tersebut. Berbeda dengan Akun, Page tidak memiliki batasan teman dan konten di dalamnya bersifat publik.

Halaman ditujukan untuk merek, bisnis, organisasi dan tokoh masyarakat untuk membuat kehadiran di Facebook, sedangkan profil mewakili setiap individu. Siapa saja dengan akun dapat membuat Halaman atau membantu mengelola halaman, jika mereka sudah diberi peran di Halaman seperti pengurus atau penyunting.

Orang yang menyukai Halaman Anda dan teman mereka akan mendapatkan pembaruan di Kabar Berita.

\section{Membuat Akun Facebook}

Jika Anda tidak mempunyai akun Facebook, Anda dapat membuat dalam beberapa langkah:

\section{Buka www.facebook.com.}

2. Jika Anda melihat formulir pendaftaran, isikan nama, alamat email atau nomor telepon, kata sandi, tanggal lahir, dan jenis kelamin. Jika Anda tidak melihat formulir ini, klik Daftar, kemudian isilah formulirnya.

3. Klik Daftar.

4. Setelah mendaftar, Anda harus mengonfirmasi email atau nomor telepon Anda. 
Facebook membantu Anda terhubung dan berbagi dengan orang-orang dalam kehidupan Anda.

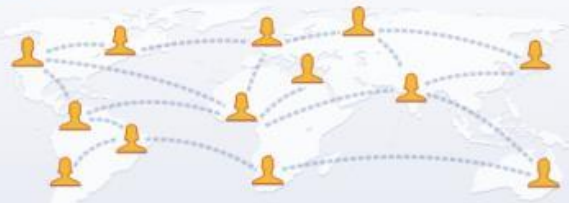

\section{Daftar}

Gratis, sampai kapan pun.

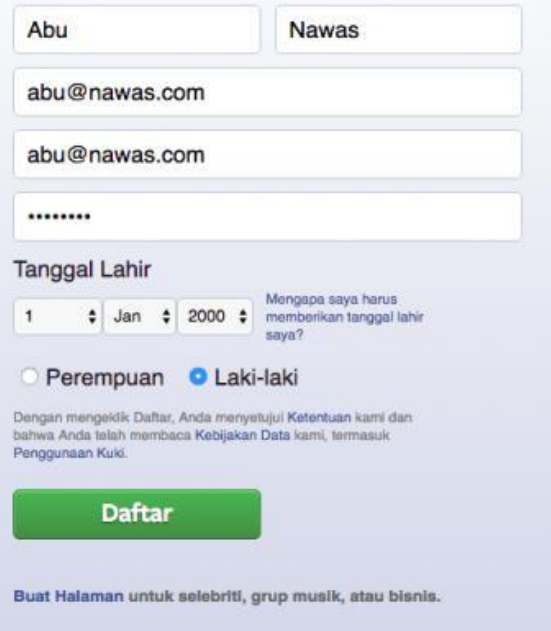

5. Jika Anda sudah mempunyai akun Facebook, Anda dapat masuk ke akun Anda dengan memasukkan email atau nomor telepon dan kata sandi Anda lalu klik Masuk. Catatan: Anda harus berusia 13 tahun ke atas untuk mendaftar Facebook.

\section{Membuat Facebook Page}

Page digunakan untuk membantu bisnis, merek, organisasi, dan tokoh publik guna membagikan kisah mereka dan terhubung dengan orang. Seperti profil, Page dapat disesuaikan dengan berita, acara, dan lainnya. Orang yang menyukai Halaman Anda dan teman mereka akan mendapatkan pembaruan di halaman Facebook mereka.

Cara untuk membuat Halaman:
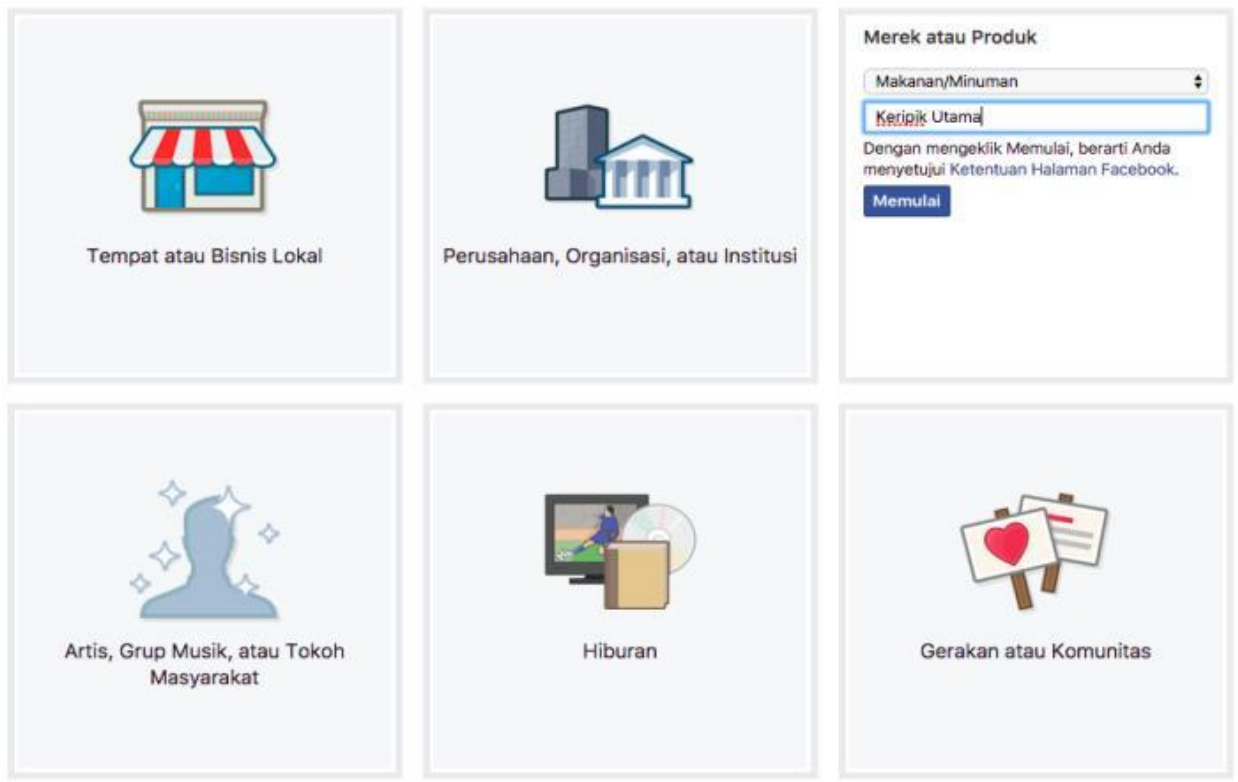

81 Kemendagri - sylabus - 2018 


\section{Buka facebook.com/pages/create}

2. Klik untuk memilih kategori Halaman (Perusahaan, Organisasi, dan Institusi atau Merek atau Produk)

3. Pilih kategori yang lebih spesifik dari menu pilihan sesuai dengan bidang usaha Anda

4. Klik Memulai dan ikuti petunjuk di layar

5. Isilah deskripsi Usaha/Produk Anda. Tambahkan

juga URL kustom (facebook.com/namaproduk)untuk memudahkan orang mencari Page Anda

\section{Pengaturan Keripik Utama}

1 Tentang $>2$ Foto Profil $>3$ Tambahkan ke Favorit $\gg 4$ Pemirsa Halaman Pilihan

Kiat: Tambahkan deskripsi dan situs web untuk meningkatkan peringkat Halaman Anda dalam pencarian. Petak bertanda bintang (") wajib dilisi.

Tambahkan beberapa kalimat untuk menjelaskan tentang Halaman Anda. Penjelasan ini akan membantu menampilkan hasil pencarian yang tepat. Anda akan dapat menambahkan detail lain dari pengaturan Halaman Anda selanjutnya.

Yuk ah

Situs web (mis: tautan situs web Anda, Instagram, Twitter, atau media sosial lainnya)

Orang-orang akan lebih mudah menemukan Halaman Anda di pencarian jika Halaman tersebut memiliki nama pengguna yang unik. Halaman dengan nama pengguna juga dapat membuat URL khusus yang memungkinkan orangorang mengunjungi dan mengirim pesan ke Halaman dengan cepat.

http://www.facebook.com/ keripikutama

(1) Isi foto profil Anda. Disarankan foto profil adalah logo perusahaan/produk Anda. Kalau tidak, bisa juga dengan foto produk Anda yang sesuai.

(2) Facebook akan membantu Anda untuk memberitahu teman-teman Anda agar menyukai Page yang baru Anda buat. 


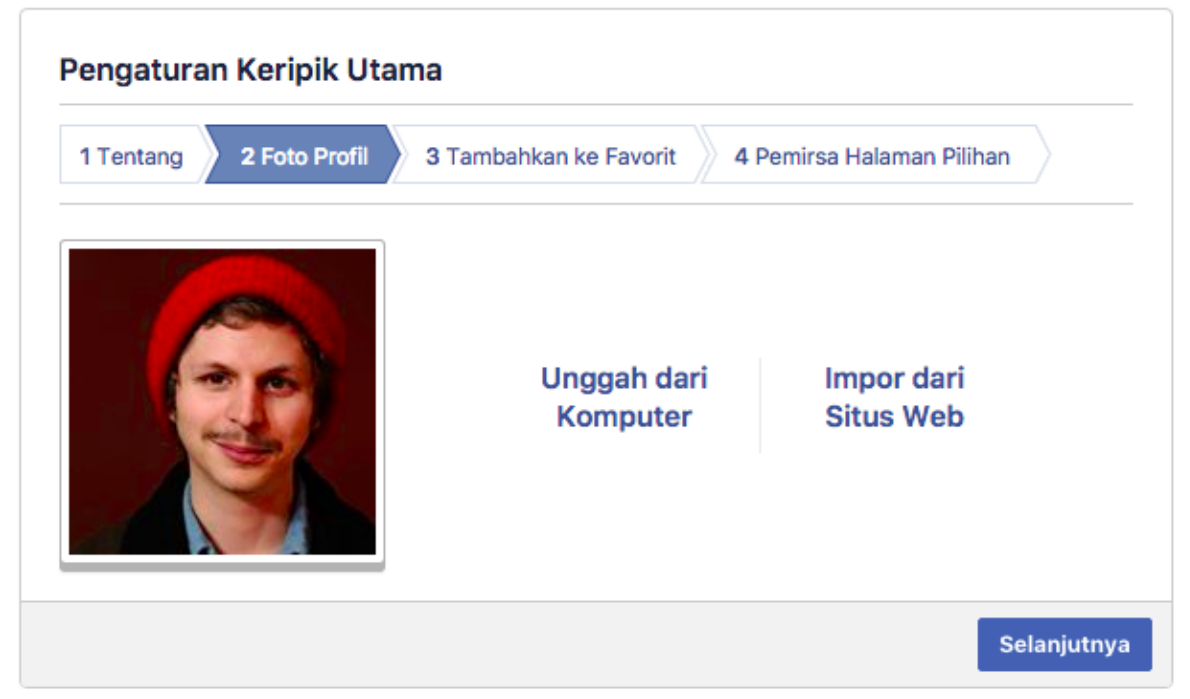

Namun Anda bisa juga memberikan informasi lebih detail tentang siapa target market yang kira-kira cocok. Selamat! Anda baru saja membuat Facebook Page untuk usaha Anda!

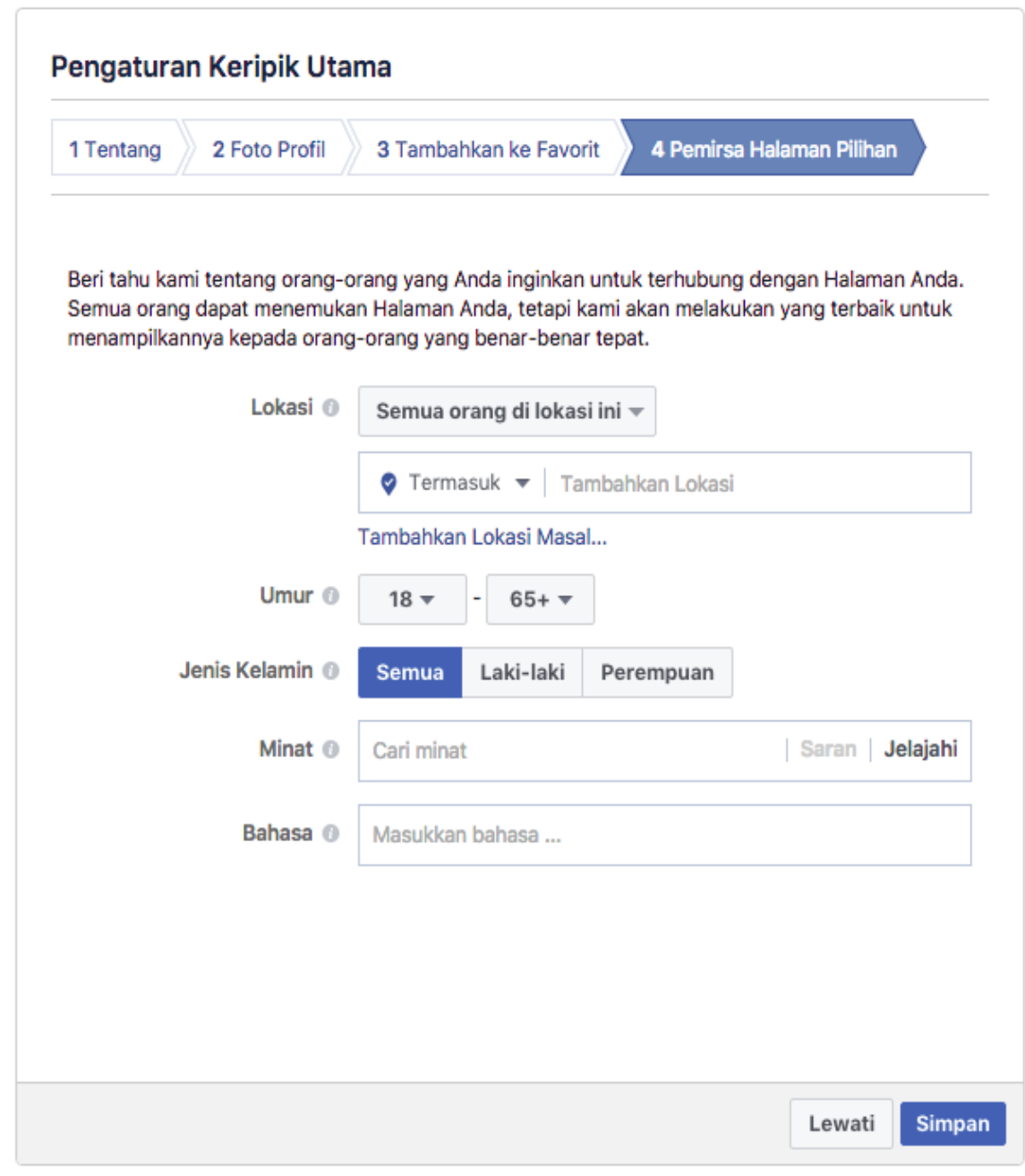

83 Kemendagri - sylabus - 2018 


\section{Menambah Foto Sampul}

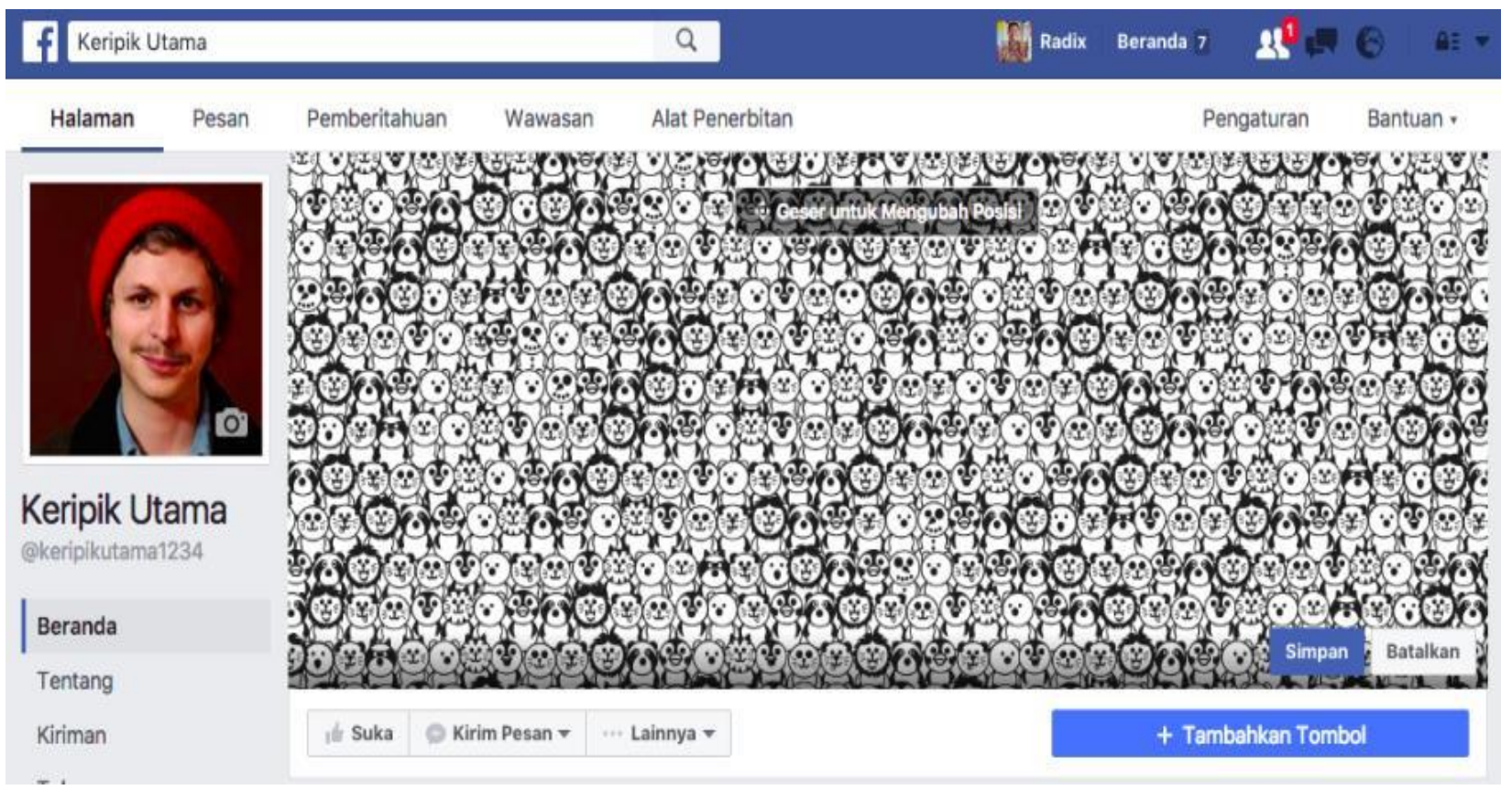

Foto Sampul adalah gambar besar yang akan terpampang di Page Anda. Foto sampul yang merepresentasikan produk atau usaha Anda dengan baik akan menimbulkan kesan baik bagi orang-orang yang melihat Page Anda, jadi jangan lupakan hal ini!

Cara menambah foto sampul adalah:

(1) Buka Halaman Anda

(2) Arahkan kursor ke gambar profil Anda dan klik

(3) Pilih opsi dan ikuti petunjuk di layar: a. Pilih foto yang sudah Anda bagikan dari Halaman Anda

(1) Mengambil foto baru

(1) Mengunggah foto dari komputer

\section{Berbagi di Facebook}

Salah satu fungsi utama Facebook Page adalah Anda bisa berbagi kabar terbaru dengan para fans (orang-orang yang memberi Page Anda "like"). Kabar yang dibagikan bisa saja berupa produk baru, informasi diskon, ataupun informasi lainnya. 


\section{Status $\circ$ Foto / Video $\ldots$ Peristiwa, Tonggak Sejarah + If}

\section{(7). Kucing ini cemberut|}

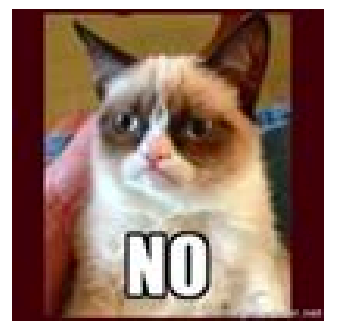

○)

Untuk berbagi di Page Anda, caranya adalah:

1. Klik di area update status

2. Tuliskan pesan yang ingin Anda terbitkan

3. Tambahkan juga foto atau video. Konten dengan foto atau video telah terbukti lebih mengundang perhatian dibanding konten yang hanya berupa tulisan saja.

4. Anda bisa menambahkan lebih dari satu foto ke dalam sebuah status update.

Pastikan lagi bahwa tidak ada kesalahan penulisan. Kalau Anda sudah yakin, klik tombol "Terbitkan"

Konten akan muncul kepada pengguna yang sudah menjadi fans Anda.

\section{Peran di Page}

Anda bisa juga memberikan pengguna Facebook lain akses untuk mengelola Page Facebook perusahaan Anda. Dengan demikian, Anda bisa berbagi tugas dengan orang lain. 


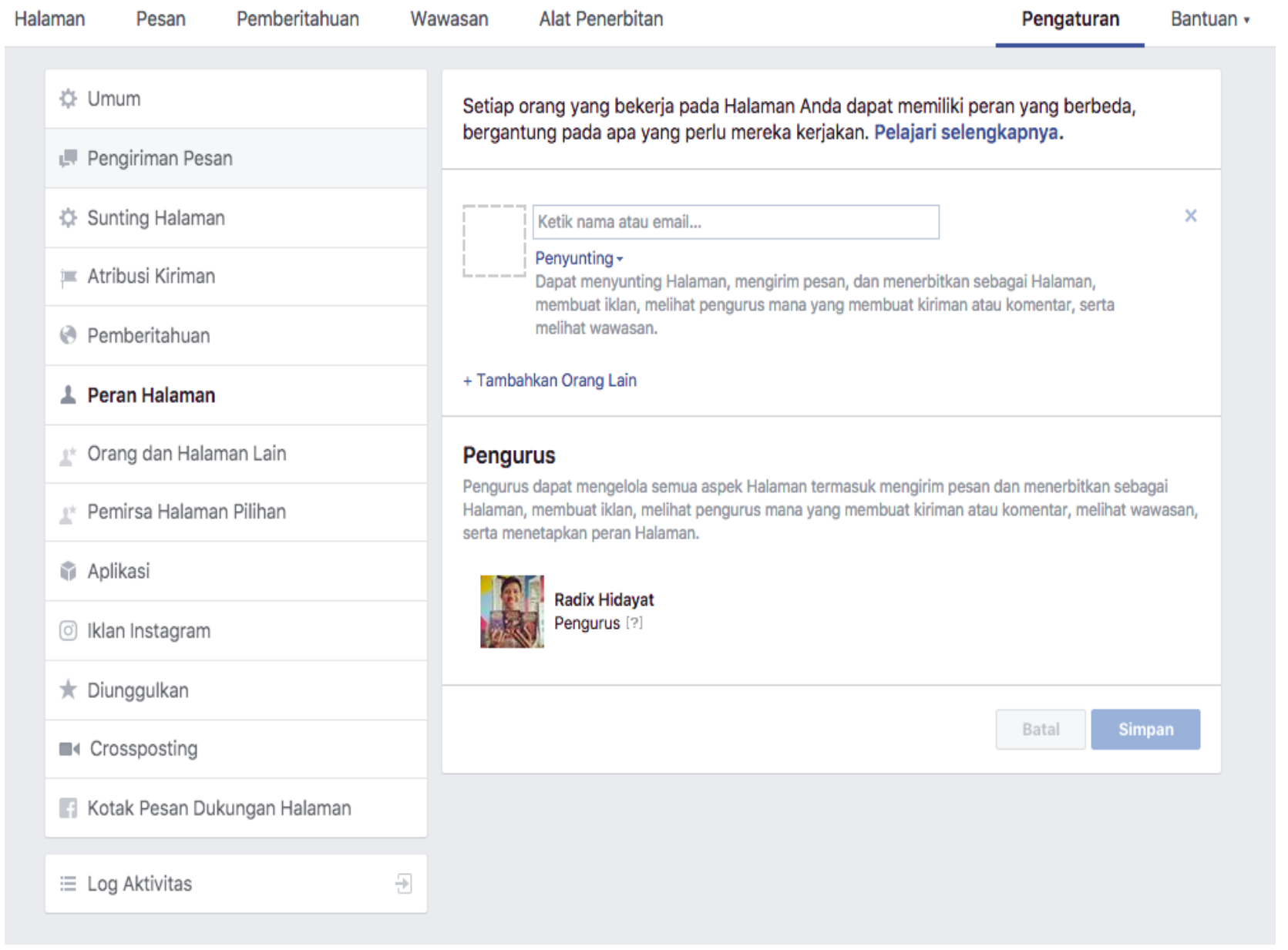

Cara menambah peran di Page Anda adalah:

1. Klik menu "Pengaturan" di bagian kanan atas Page Anda

2. Pilih menu "Peran Halaman"

3. Ketik nama orang yang ingin Anda undang. Orang yang diundang haruslah sudah menjadi teman Anda.

4. Klik "Simpan".

\section{Menambah Tombol Tindakan}

Tombol Tindakan adalah tombol yang akan muncul di profil Page Anda. Tombol ini bisa disesuaikan untuk kebutuhan Anda, untuk mengajak pengunjung profil agar:

1.

2.

3.

4.
- Memesan Layanan

- Menghubungi bisnis Anda

- Mempelajari lebih jauh tentang usaha Anda

- Melakukan pembelian

86 Kemendagri - sylabus - 2018 


\section{Tambahkan sebuah Tombol ke Halaman Anda}

What would you like people to do on your page?

\#esan Layanan kami

Terhubung dengan Kami

\section{Pelajari Selengkapnya Tentang Kami}

Lakukan Pembelian atau Sumbangan

if Gunakan Aplikasi atau Game Kami

\section{Menambah Fans pada Page Anda}

Semakin banyak fans yang menyukai Page Anda semakin banyak juga orang yang akan menerima status update yang Anda buat -- dan ini berarti semakin besar potensi pasar untuk produk Anda.

Menambah fans di Facebook Page itu gampang- gampang susah. Pada intinya, semakin menarik konten yang diberikan di Page Anda maka semakin banyak orang yang akan tertarik untuk menjadi fans di Page

Anda. Namun, definisi konten yang menarik sendiri akan berbeda untuk setiap orang dan setiap waktu.

87 Kemendagri - sylabus - 2018 
Untuk permulaan, Anda bisa mengajak teman-teman Anda di Facebook untuk menjadi fans, karena pada awal Anda mengembangkan bisnis, Anda memberi tahu teman dan keluarga terlebih dahulu, bukan?

1. Klik tombol "Promosikan" di bagian kiri Page

2. Pilih "Undang Teman Anda"

3. Klik "Undang" di sebelah kanan nama teman yang hendak Anda undang. Anda juga bisa mengetik di kolom nama untuk mencari teman tertentu.

\section{Apa yang ingin Anda lakukan?}

\section{Promosikan Situs Web Anda}

Ajak lebih banyak orang mengunjungi situs web

Anda

Promosikan Halaman Anda

Hubungkan lebih banyak orang dengan Halaman

Anda

\section{Undang Teman Anda}

Kembangkan pemirsa Anda dengan mengundang teman-teman

\section{Lihat Semua Promosi}

\section{Promosikan}

\section{$\boldsymbol{\nabla}$}

\section{Instagram}

Instagram adalah media sosial yang fokus untuk berbagi foto. Instagram pertama kali diluncurkan ke publik pada tahun 2011 dan hingga kini telah mencapai 500 juta pengguna dan di Indonesia sendiri pengguna aktifnya sudah lebih dari 20 juta orang.

Jika usaha Anda bergerak di bidang produk konsumen (makanan, minuman, pakaian, perabot rumah tangga, dII), maka Instagram sangatlah cocok untuk digunakan untuk mengembangkan bisnis Anda. 


\section{Membuat Akun Instagram}

1. Unduh aplikasi Instagram di App Store (iOS) atau Google Play Store (Android)

2. Sesudah aplikasi terpasang di ponsel Anda, buka aplikasi tersebut

3. Tekan "Buat Akun"

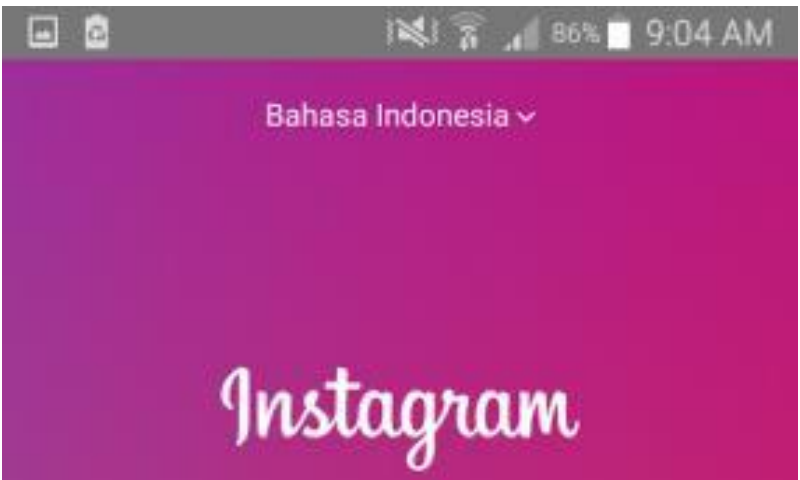

Nama Pengguna

Kata Sandi

Masuk

Lupa detail informasi masuk Anda? Dapatkan bantuan untuk masuk.

ATAU

Masuk dengan Facebook

Tidak punya akun? Bunt Akun.

4. Anda bisa memilih untuk membuat akun dengan Facebook atau Email. Pilih buat akun email/no telepon

89 Kemendagri - sylabus - 2018 


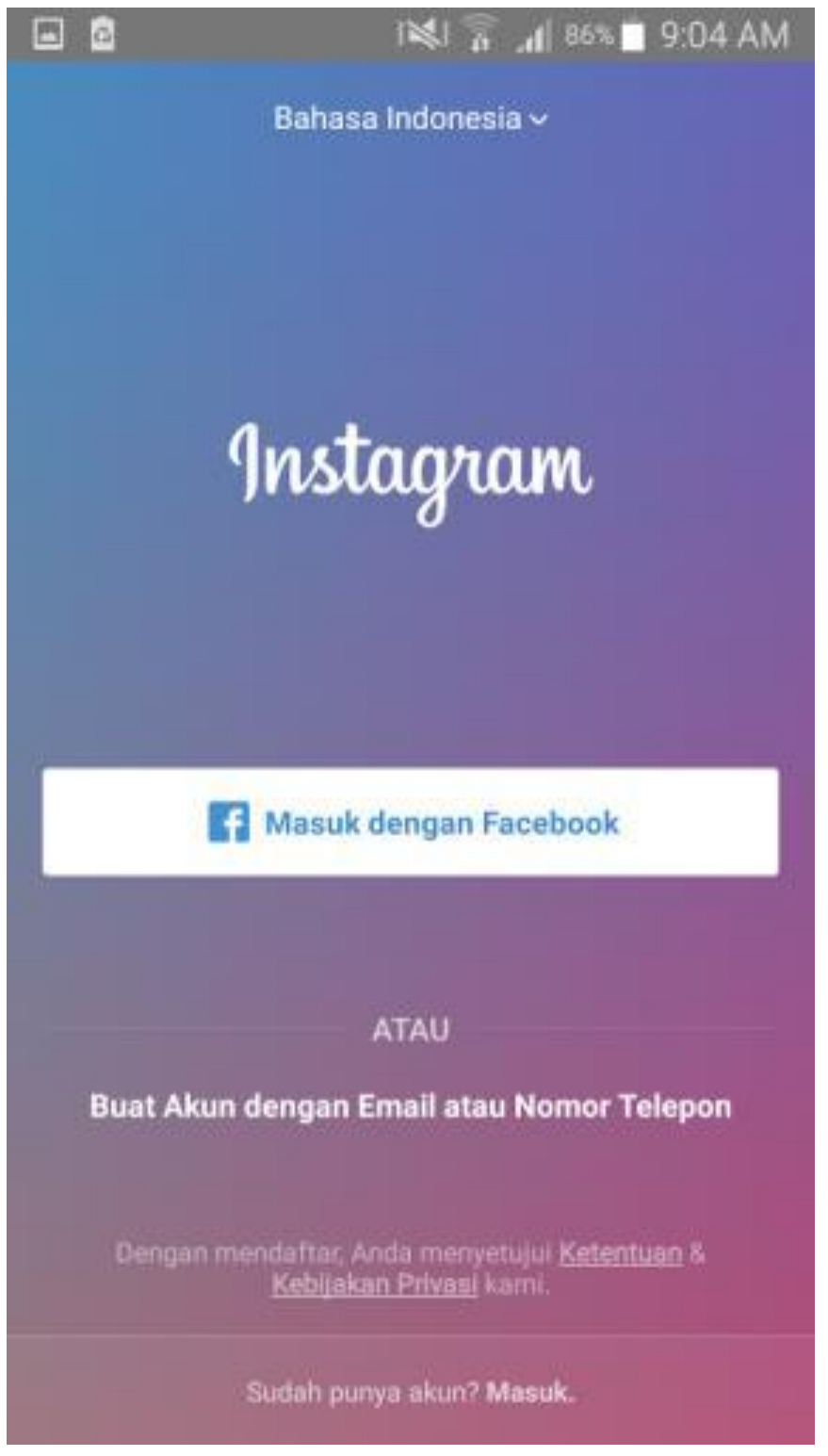

5. Tekan tab Email, lalu masukkan alamat amail

6. Masukkan nama usaha/produk Anda dan tentukan password yang ingin digunakan

7. Instagram lalu akan menyarankan nama akun yang akan digunakan. Anda masih bisa mengganti nama akun tersebut dengan yang lain.

8. Anda bisa mengikuti teman Facebook Anda juga

9. Tambahkan foto profil. Anda bisa juga menambahkan foto profil yang sama dengan logo di Facebook Page Anda untuk menjaga konsistensi. 
Selamat! Akun Instagram Anda sudah berhasil dibuat!

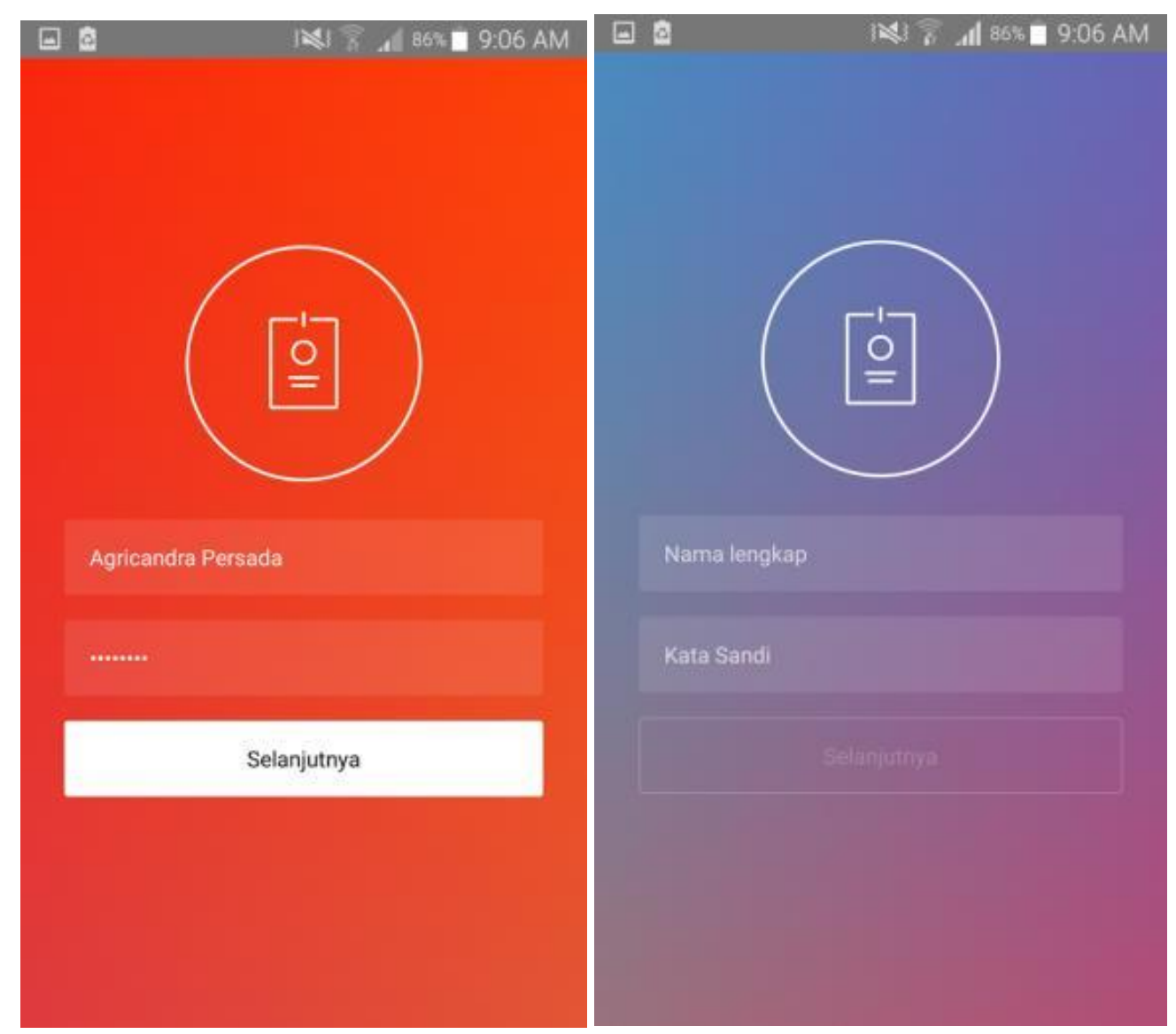

\section{Membuat Post di Instagram}

Post yang dibuat di Instagram akan terlihat oleh pengikut Anda maupun muncul di bagian Pencarian

1. Tekan tombol kamera di bagian tengah bawah

2. Anda bisa memilih untuk mengirimkan foto/video yang ada di galeri foto, mengambil foto, atau merekam video. Untuk sekarang, pilih salah satu foto di galeri foto ponsel Anda

3. Mode standar di Instagram adalah foto berukuran persegi. Geser-geser foto yang akan dikirim untuk mendapatkan sudut terbaik. Kalau sudah yakin, tekan "Selanjutnya"

4. Salah satu keunggulan di Instagram adalah filter. Filter membuat foto Anda jadi tampak lebih cantik dengan mudah. Cobalah filter-filter yang ada sampai Anda menemukan filter yang cocok dengan foto Anda. Kalau sudah cocok, tekan "Selanjutnya" 

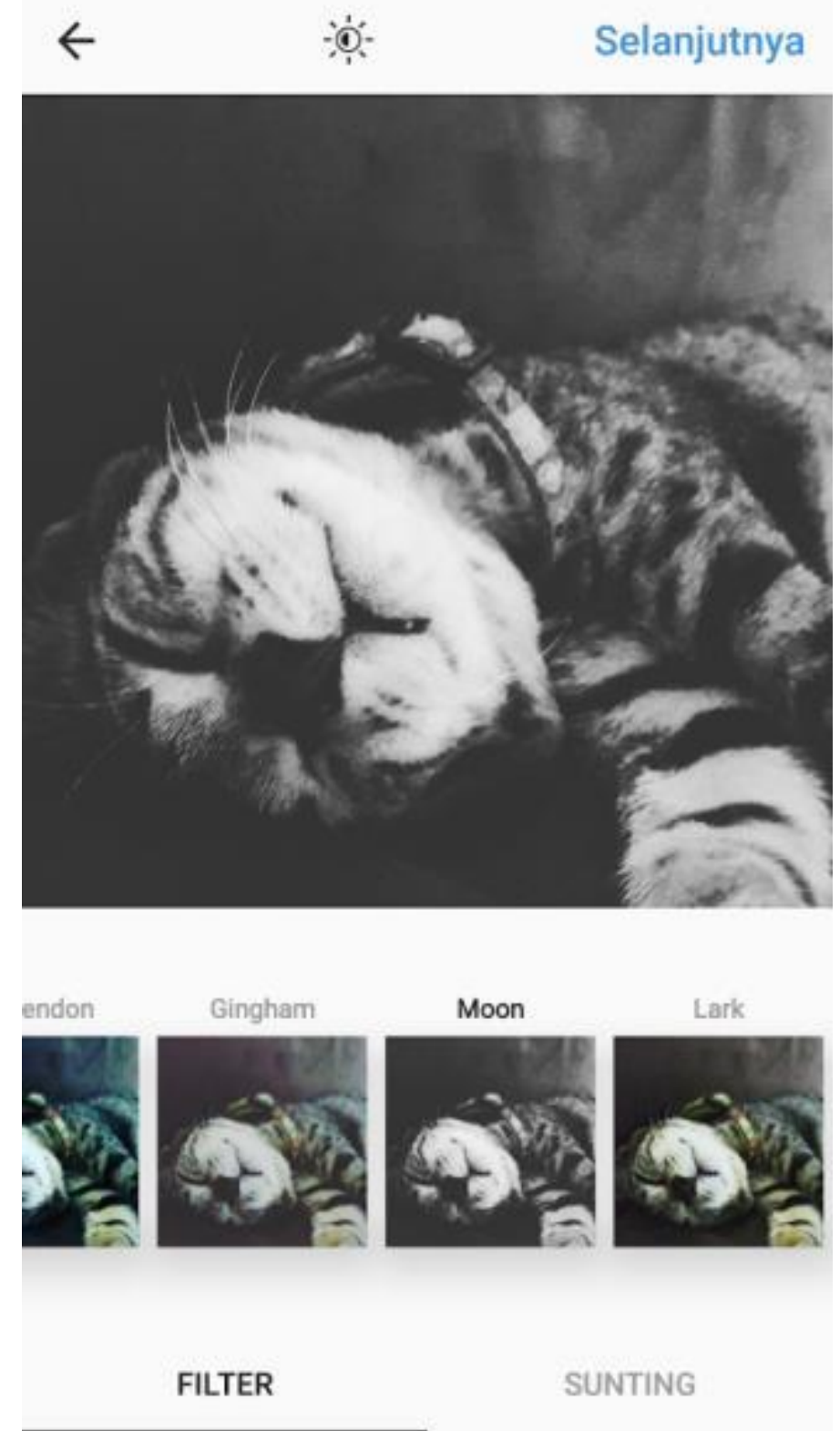

5. Tulislah keterangan tentang foto. Apabila Anda membuat post tentang produk Anda, maka keterangan sebaiknya menjelaskan detail produk Anda, material yang digunakan, manfaat, keunggulan, serta harga dan bagaimana cara mendapatkannya.

6. Anda bisa juga menambahkan lokasi serta menandai pengguna Instagram yang lain. Jangan khawatir, Anda selalu bisa mengubah keterangan, lokasi, serta menandai orang nanti bahkan setelah dikirim

7. Tekan tombol "Bagikan" dan foto Anda akan terkirim! 


\section{Mengambil Foto yang Baik}

Instagram adalah layanan untuk berbagi foto, maka pastikan bahwa foto yang Anda sebarkan di Instagram juga memiliki kualitas yang baik. Berikut beberapa tips untuk membuat foto yang baik:

Komposisi adalah nomor 1. Pastikan ada satu objek utama dan objek-objek lain hanya berfungsi sebagai pendukung.

Gunakan "rule of third". Posisikan bagian yang menarik di persimpangan antara garis-garis panduan. Garis panduan ini bisa diaktifkan di kamera ponsel Anda.
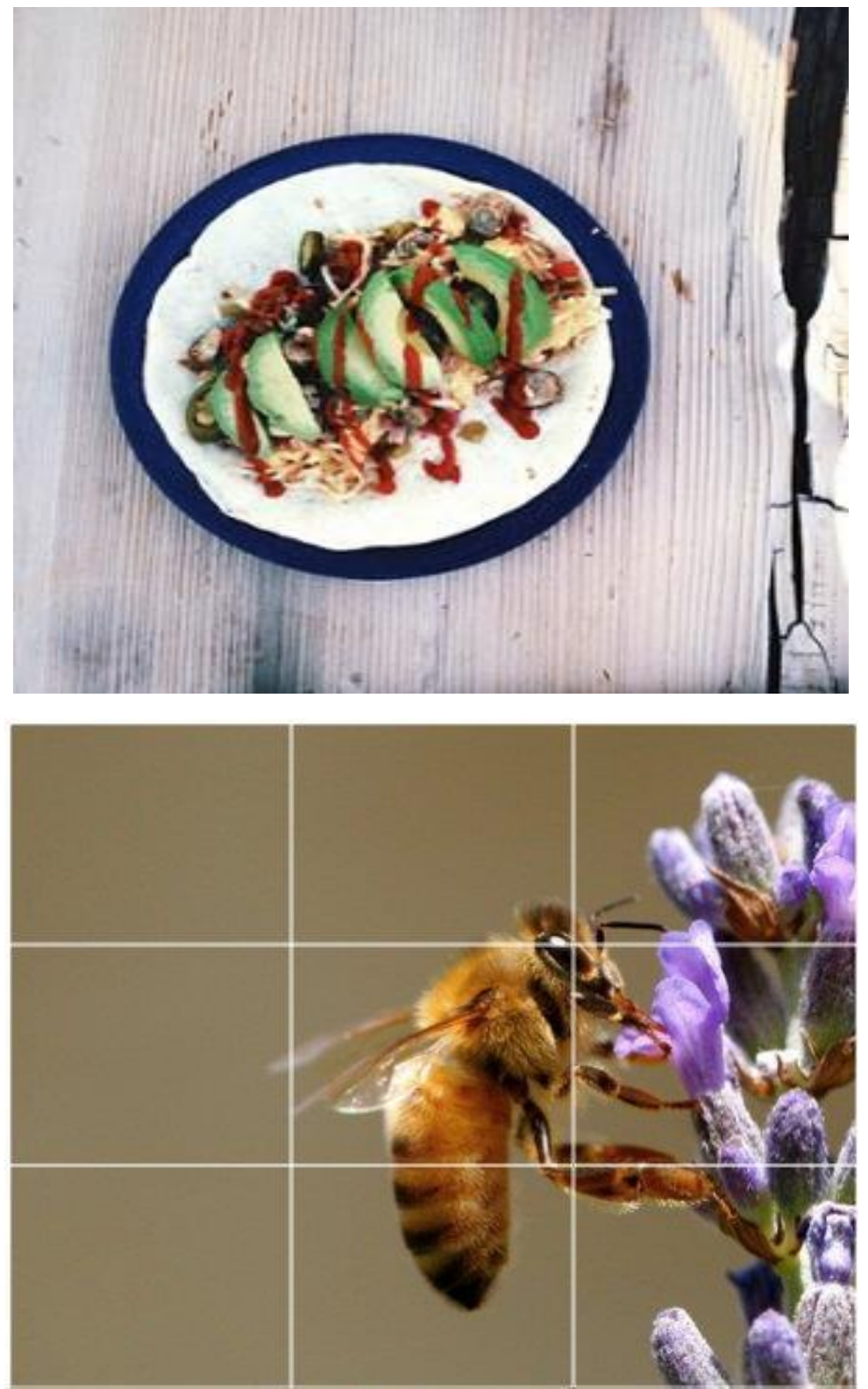

Gunakan "negative space". Negative space adalah istilah fotografi untuk area kosong di 
sekeliling objek foto utama. Terkadang, kekosongan dan kesederhanaan adalah hal yang baik!

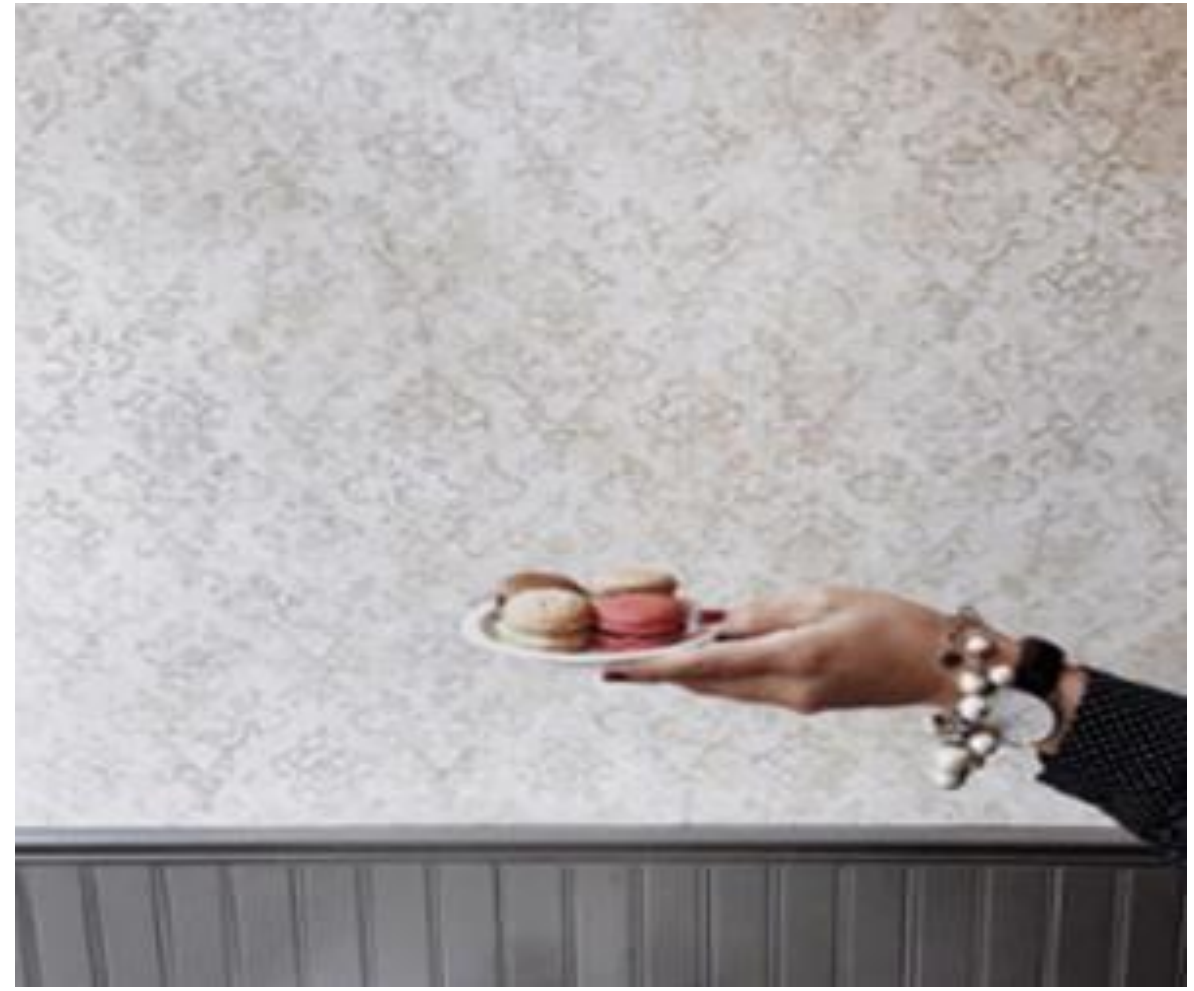

Gunakan "Depth of Field". Fokuskan gambar pada objek foto utama dan biarkan yang lain menjadi kabur!

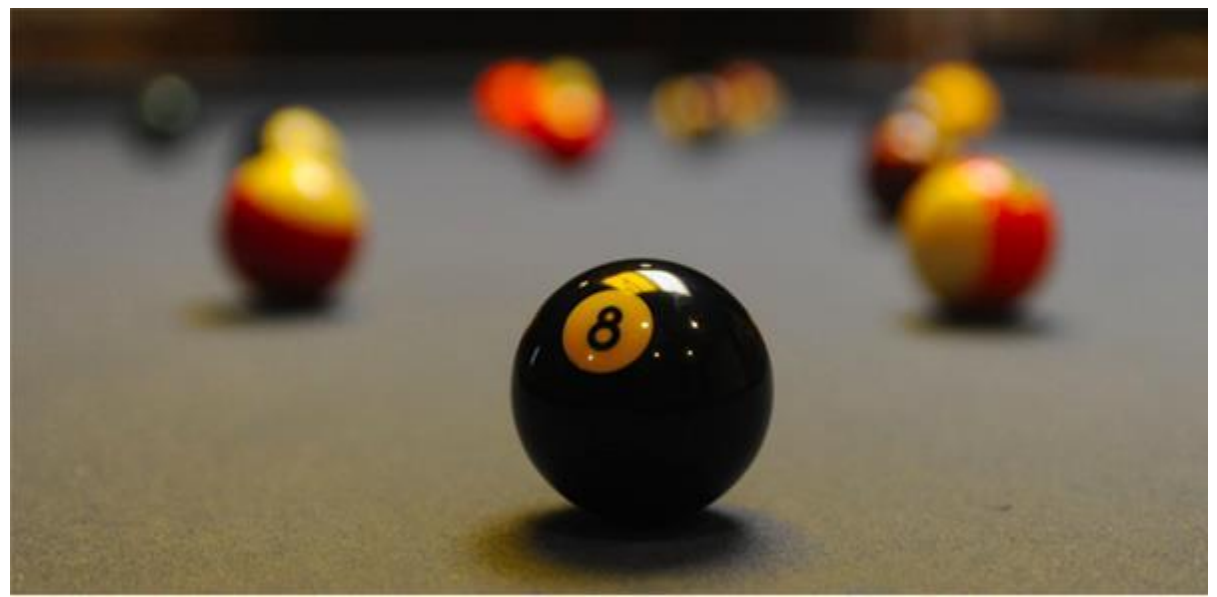

\section{Menulis Keterangan Foto}

Walaupun Instagram adalah layanan berbagi foto, menulis keterangan foto yang baik pun tidak kalah pentingnya!

94 Kemendagri - sylabus - 2018 
Jika Anda mengirim foto tentang produk Anda ke Instagram, maka pastikan bahwa di keterangan foto tercantum:

- Nama produk

- Detail mengenai produk (bahan, kegunaan, keunggulan)

- Harga

- Bagaimana cara mendapatkannya (kontak WhatsApp/BBM, e-mail, website)

Selain bahasa

sudah sesuai untuk mereka?

- Secara umum, sedikit humor selalu akan menarik perhatian

- Keterangan di foto Instagram hanya akan terlihat pada 3 baris pertama (yang akan terbuka semua kalau diklik). Maka sebaiknya tempatkan kata- kata paling penting di awal untuk menarik perhatian itu, perlu juga untuk diperhatikan tentang gaya yang sebaiknya digunakan di Instagram:

- Perhatikan siapa target market untuk produk Anda? Apakah gaya bahasa yang Anda gunakan

- Tautan di foto Instagram tidak bisa diklik kecuali di profil Anda, maka selalu arahkan pengikut Anda untuk mengklik tautan di profil Anda

- Gunakan emoji!, Emoji sudah tersedia di keyboard bawaan di iPhone maupun Android Hashtag Hashtag (tanda pagar) adalah kata-kata yang memiliki simbol \# di depannya. Beberapa contoh hashtag adalah \#indonesia \#karyaanakbangsa dan banyak lagi. Anda bisa menaruh hashtag di keterangan atau komentar di foto Instagram, karena menurut penelitian, foto yang memiliki hashtag lebih menarik perhatian dibandingkan yang tidak. Cara menambah hashtag di foto Anda:

1. Di kolom keterangan foto, tekan simbol "\#” dari keyboard Anda

2. Mulai ketik sesuatu, dan Instagram otomatis akan mencarikan hashtag yang mirip beserta jumlah foto yang sudah memiliki hashtag tersebut

3. Pilih hashtag yang kira-kira cocok dengan foto Anda 
4. Tekan tombol "Sebarkan"

Seperti apakah hashtag yang baik?

- Coba gunakan nama brand produk Anda sebagai hashtag, jadi Anda bisa mengajak fans produk Anda untuk menggunakannya juga

- Perhatikan kategori produk Anda. Jika Anda menjual tas untuk bepergian, hashtag yang umum digunakan adalah \#travel, \#wanderlust, \#indonesiatravel, dll.

- Sangat disarankan untuk selalu mempelajari apa saja hashtag yang populer dan kirakira sesuai dengan brand ataupun produk Anda.

- Anda bisa menaruh hashtag di kolom komentar juga jadi foto Anda akan terlihat lebih rapih di depan

- Jangan gunakan hashtag yang tidak sesuai dengan produk Anda Jelajah Instagram Foto yang Anda kirimkan tidak hanya terlihat oleh pengikut Anda saja, tetapi juga akan muncul di bagian "Jelajah" di Instagram. Jelajah akan menampilkan foto- foto dari akun yang diikuti oleh akun yang Anda ikuti, jadi foto Anda bisa saja muncul di halaman Jelajah pengguna yang belum menjadi pengikut Anda!

\section{Instagram untuk Bisnis}

Instagram memiliki fitur khusus untuk bisnis dan merek, seperti tombol kontak khusus, informasi mengenai pengikut maupun kinerja akun Instagram Anda, serta perangkat untuk beriklan di Instagram.

Untuk bisa membuat profil bisnis di Instagram, Anda harus menghubungkan Page Facebook Anda ke Instagram. 


\section{Modul I}

12. Laporan Keuangan Sederhana Penjelasan Umum Modul

\subsection{Laporan Keuangan}

\subsubsection{Pemahaman Umum tentang Laporan Keuangan}

\subsubsection{Menggunakan software untuk pencatatan keuangan}

Output:

1. Peserta paham tentang pentingnya memiliki laporan keuangan

2. Peserta bisa menggunakan aplikasi AkuntingMudah untuk membuat laporan keuangan bisnis

Estimasi durasi untuk mengerjakan secara mandiri: 1-3 jam

Dukungan yang dibutuhkan:

o Pendampingan Mentor untuk membahas cara membaca laporan keuangan (laba/rugi)

o Pendampingan untuk menggunakan aplikasi Akunting Mudah 


\section{Lembar Kerja Modul Laporan Keuangan Sederhana}

Sebelum kita mulai, mari mengingat kembali apa yang sudah dipelajari dalam modul dasar "Pencatatan Keuangan Sederhana":

Pisahkan rekening pribadi dan bisnis

1. Apakah Anda sudah memiliki rekening terpisah untuk pribadi dan bisnis?

2. Bagaimana Anda mengambil uang untuk pribadi saat ini?

(ada 2 cara yang disebutkan di modul Pencatatan Keuangan Sederhana) Catat semua transaksi dan uang keluar masuk bisnis

Apakah Anda sudah memiliki Buku Kas tempat mencatat semua pengeluaran dan pemasukan bisnis? Jika Anda belum melakukan kedua hal di atas, Anda belum siap untuk mempelajari modul ini. Ingat, PRAKTEK LEBIH PENTING DARI SEKEDAR BELAJAR!

\section{A. Laporan Laba Rugi}

Dalam bisnis, Anda tidak perlu mengerti semua hal tentang cara membuat laporan keuangan. Pembuatan laporan bisa dilakukan oleh akuntan atau menggunakan aplikasi. Dalam hal ini kami menganjurkan untuk menggunakan aplikasi AkuntingMudah

Sebagai pemilik bisnis, hal yang paling penting adalah Anda bisa membaca hasil laporan keuangan dan menentukan langkah berikut

Pendapatan Biaya Produksi - Laba (Rugi) Kotor Biaya Operasional - Laba (Rugi) Bersih Pengertiannya adalah: Pendapatan: semua uang masuk hasil penjualan

Biaya Produksi: semua uang keluar untuk membeli bahan baku atau belanja barang untuk dijual lagi (kulakan)

Laba (Rugi) Kotor: biasa juga disebut marjin kotor, penting untuk mengetahui apakah harga jual sudah benar. Ternyata marjin kotor Anda negatif (rugi), maka jelas bisnis ini tidak menguntungkan!

Biaya Operasional: semua uang keluar selain untuk bahan baku atau belanja barang (termasuk gaji Anda sendiri) 
Laba (Rugi) Bersih: menunjukkan keuntungan akhir usaha Anda

Laporan Laba Rugi dapat dibaca secara umum dengan mudah sebagai berikut:

Laba Rugi

August 2012

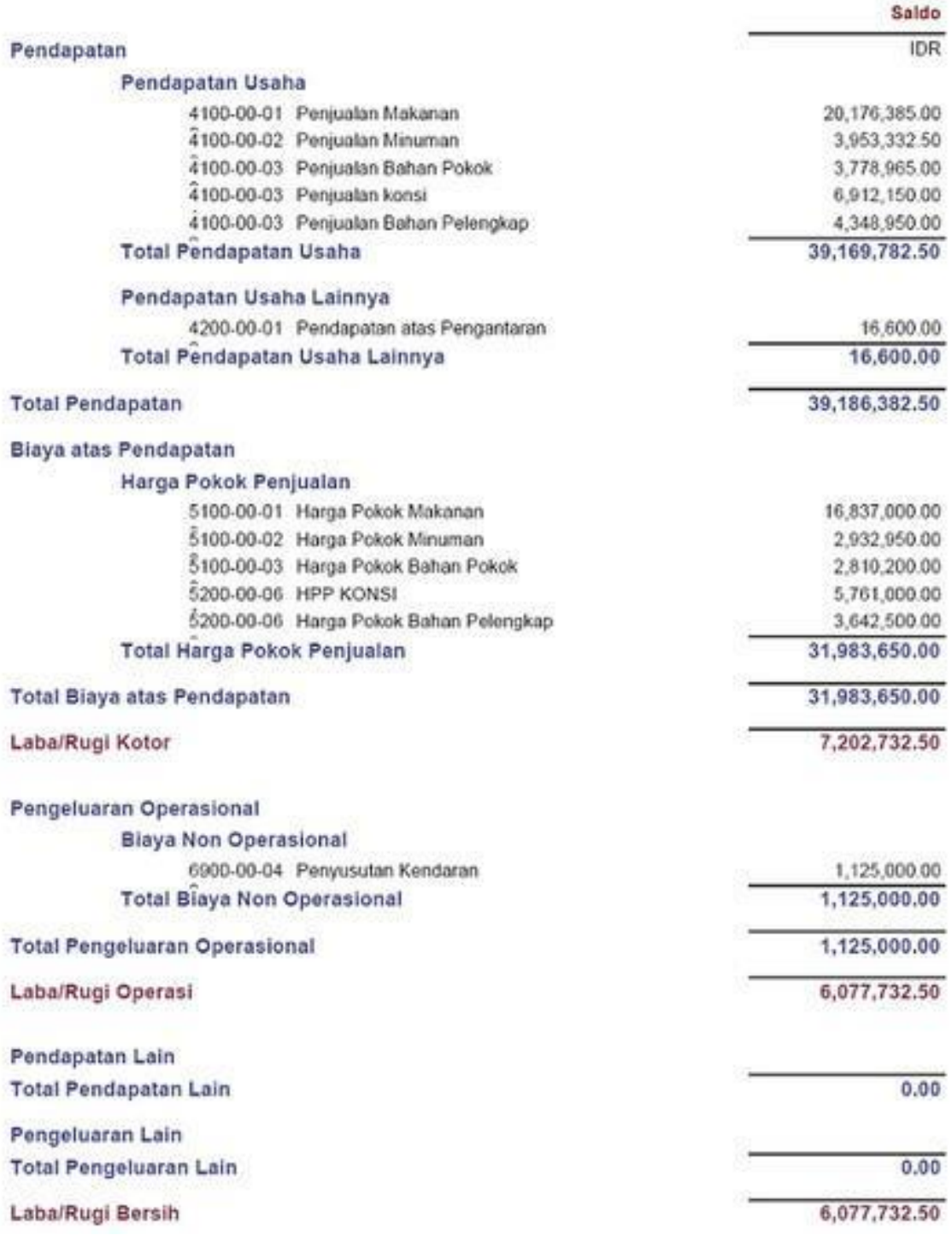

Pendapatan dikurangi Biaya Produksi = Laba Kotor

Laba Kotor dikurangi Biaya Operasional = Laba Bersih 


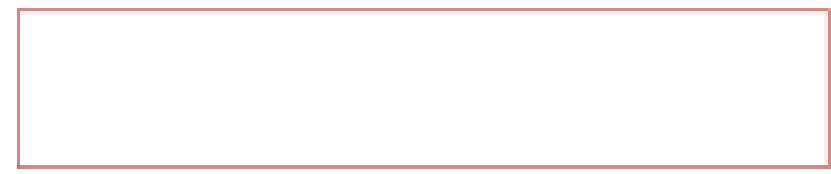

Ingat rumus mudah dan sederhana:

Setelah memiliki Laporan Laba Rugi, Anda perlu memikirkan hal-hal berikut untuk langkah selanjutnya:

(3) Apakah Laba Kotor sudah tercapai?

a) Jika Tidak, apakah ada cara supaya bisa mencapai laba kotor? Contoh: menaikkan harga jual atau menurunkan biaya produksi. Kalau masih terus merugi, berarti usaha ini tidak menguntungkan dan lebih baik TIDAK DILANJUTKAN

b) Jika Ya, apakah ada potensi supaya Laba Kotor bisa dinaikkan?

(4) Apakah Laba Bersih sudah tercapai?

a) Jika Tidak, apakah ada cara supaya bisa mencapai laba bersih? Contoh: menurunkan biaya operasional atau memperbaiki Laba Kotor (lihat poin 1)

b) Jika Ya, apakah jumlah laba sudah cukup menarik? Bagaimana cara memperbaiki laba bersih? Contoh: menjual lebih banyak unit, memperbaiki marjin kotor, dll Disusun oleh Kinara Indonesia untuk PT. Telkom Indonesia Tbk, 20166

B. Menggunakan Aplikasi AkuntingMudah Untuk Membuat Laporan Keuangan (sumber: akuntingmudah.blogspot.co.id)

Aplikasi AkuntingMudah sudah dirancang menjadi software akuntansi yang mudah dipahami dan dapat digunakan siapa saja. AkuntingMudah akan membantu pencatatan keuangan bisnis menjadi Lebih Mudah dipahami, Lebih Cepat dikerjakan, serta 100\% Akurat menghasilkan Laporan Keuangan.

Cara kerja AkuntingMudah pada intinya terdiri dari 3 tahap proses: 
Anda hanya perlu bekerja pada Tahap 1 (Laman Catat Transaksi dan HPP), menginput data sesuai dengan transaksi bisnis yang terjadi serta meng-customize sesuai kebutuhan bisnis Anda. Sedangkan Tahap 2 dan Tahap 3 akan otomatis diproses oleh software secara riil time.

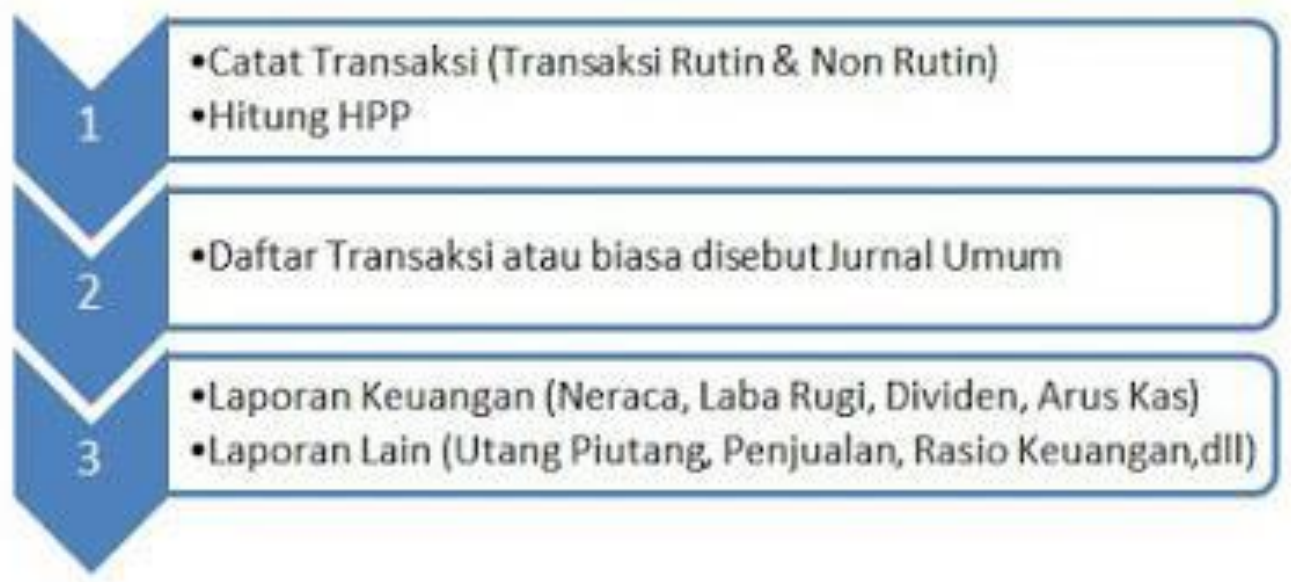

Tujuan utama akuntansi adalah menghasilkan Laporan Keuangan seperti yang dihasilkan dalam Tahap 3.

\section{CATAT TRANSAKSI}

Setelah login, Anda akan langsung masuk ke halaman Catat Transaksi, yang terdiri dari Transaksi Rutin dan Transaksi Non Rutin. Ini dibedakan berdasarkan frekuensi terjadinya suatu kategori transaksi, seperti yang terlihat pada tabel di bawah. Dengan sedikit berlatih, Anda akan dengan cepat memahami prosesnya.

Halaman Catat Transaksi secara umum terdiri dari beberapa kolom yang harus diisi dan dapat dicustomize sesuai dengan transaksi bisnis mu masing-masing. 


\begin{tabular}{|l|l|}
\hline Transaksi Rutin & -Pendapatan \\
& -Bahan Baku \\
& -Biaya \\
& -Terima Piutang \\
& -Bayar Utang \\
\hline Transaksi Non Rutin & -Peralatan \\
& -Properti \\
& -Utang Bank \\
& -Modal \\
& -Dividen \\
\hline
\end{tabular}

\begin{tabular}{|c|c|c|}
\hline KOLOM & PENJELASAN & SIFAT \\
\hline Tanggal & Diisi untuk menerangkan tanggal terjadi transaksi tersebut & \\
\hline Proyek/Divisi & $\begin{array}{l}\text { Diisi apabila bisnis mu bersifat multi proyek/multidivisi. Bisnis } \\
\text { seperti ini sering terjadi pada kontraktor, konsultan, orderan } \\
\text { konveksi, katering pernikahan dll. Kalau bisnismu bukan multi } \\
\text { proyek/multi divisi, kosongkan saja }\end{array}$ & Optional \\
\hline Kategori & Pilih yang sesuai dengan jenis transaksi yang ingin kamu catat & \\
\hline Deskripsi & $\begin{array}{l}\text { Penjelasan lebih detail dari kategoriyang kamu pilih, dimana } \\
\text { kamu bisa membuat sendiri penjelasannya }\end{array}$ & \\
\hline Vendor/Customer & Pihak lain yang terlibat dalam transaksi tersebut & Optional \\
\hline Nominal & $\begin{array}{l}\text {-Kamu dapat mengisi secara total nominal dengan } \\
\text { mengosongkan kolom "Unit" yang di set default dengan angka1 } \\
\text {-Dapat juga diisi secara rinci dengan menginput jumlah "Unit" } \\
\text { dan "Harga/unit" } \\
\text { Sesuaikan ini dengan kebutuhan mu }\end{array}$ & \\
\hline Tunai/Non Tunai & $\begin{array}{l}\text {-Tunai apabila transaksi terjadi secara cash, ada uang yang } \\
\text { berpindah. Software didefault pada "Tunai" } \\
\text {-Non Tunai apabila terjadi secara non-cash, baik ada uang muka } \\
\text { ataupun tidak. Transaksi Non Tunai akan otomatis menghasilkan } \\
\text { Utang-Piutang }\end{array}$ & \\
\hline No Bukti & $\begin{array}{l}\text { Jika adminitrasi bisnis mu sudah lebih rapi, biasanya setiap nota } \\
\text { akan diberi nomer khusus. Dapat dicatat pada kolom ini }\end{array}$ & Optional \\
\hline Upload Nota & $\begin{array}{l}\text { Jika selama ini kamu merasa repot harus menyimpan bukti nota, } \\
\text { maka dengan fitur ini kamu dapat menyimpannya secara digital, } \\
\text { sehingga tak lagi perlu khawatir hilang. }\end{array}$ & Optional \\
\hline Catatan & Apabila ada catatan khusus untuk suatu transaksi & Optional \\
\hline
\end{tabular}

\section{TRANSAKSI RUTIN}

\section{A. PENDAPATAN :}


Sering juga disebut omset, sales, revenue, ataupun penjualan. Intinya semua pendapatan yang kamu terima dari penjualan produk atau jasa.

Contoh : Tanggal 1 Desember 2013, kamu dikontrak untuk jasa pembuatan web PT. Sejahtera sebesar Rp 10.000.000. Maka dicatat seperti ini:

\section{Transaksi Rutin}

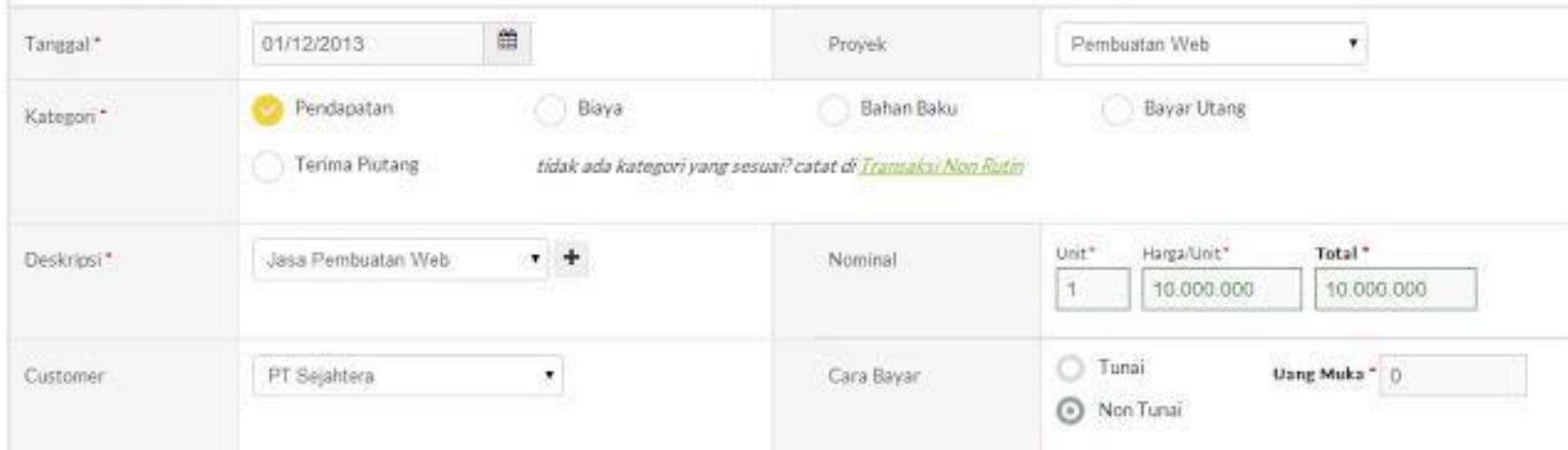

B. BAHAN BAKU :

Barang-barang yang kamu beli untuk diolah (ataupun dijual langsung) untuk menghasilkan Pendapatan. Untuk bisnis jasa, maka bahan baku dapat dianggap tidak ada.

Contoh: Tanggal 13 Desember 2013, Distro mu membeli bahan katun kombat warna putih sebanyak 50 kg dengan harga Rp 15.000/kg secara non tunai, dengan uang muka Rp 100.000 dari Toko Sakura. Maka dicatat seperti ini:

\section{Transaksi Rutin}

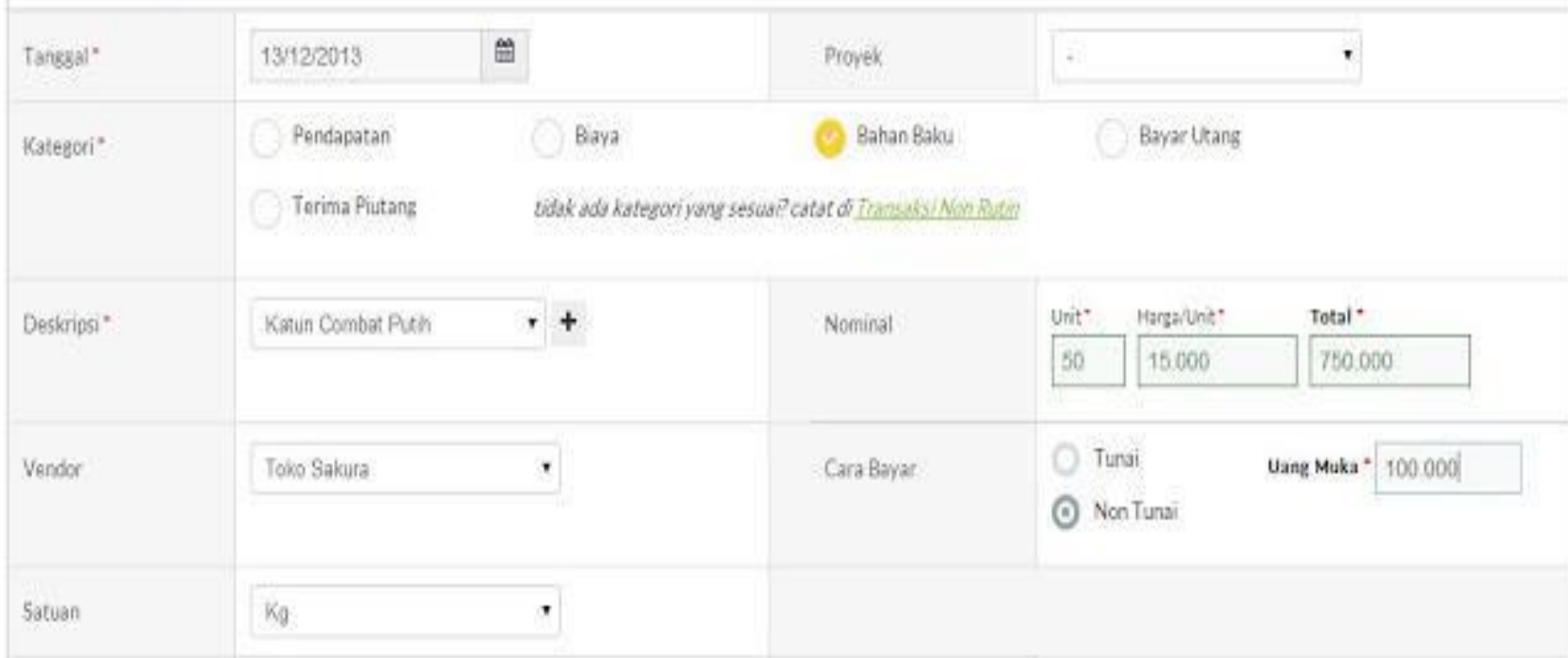




\section{BIAYA :}

Adalah biaya yang kamu keluarkan untuk mendukung operasional atau produksi. Tetapi tidak termasuk Peralatan dan Properti yang kamu miliki.

Misalnya:Gaji karyawan, Listrik, Air, Adminitrasi, Marketing, dll.

Contoh: Tanggal 14 Desember 2013, kantormu membayar honor SDM untuk proyek pembuatan Bisnis Plan di Bogor sebesar Rp 5.000.000. Dicatat seperti ini:

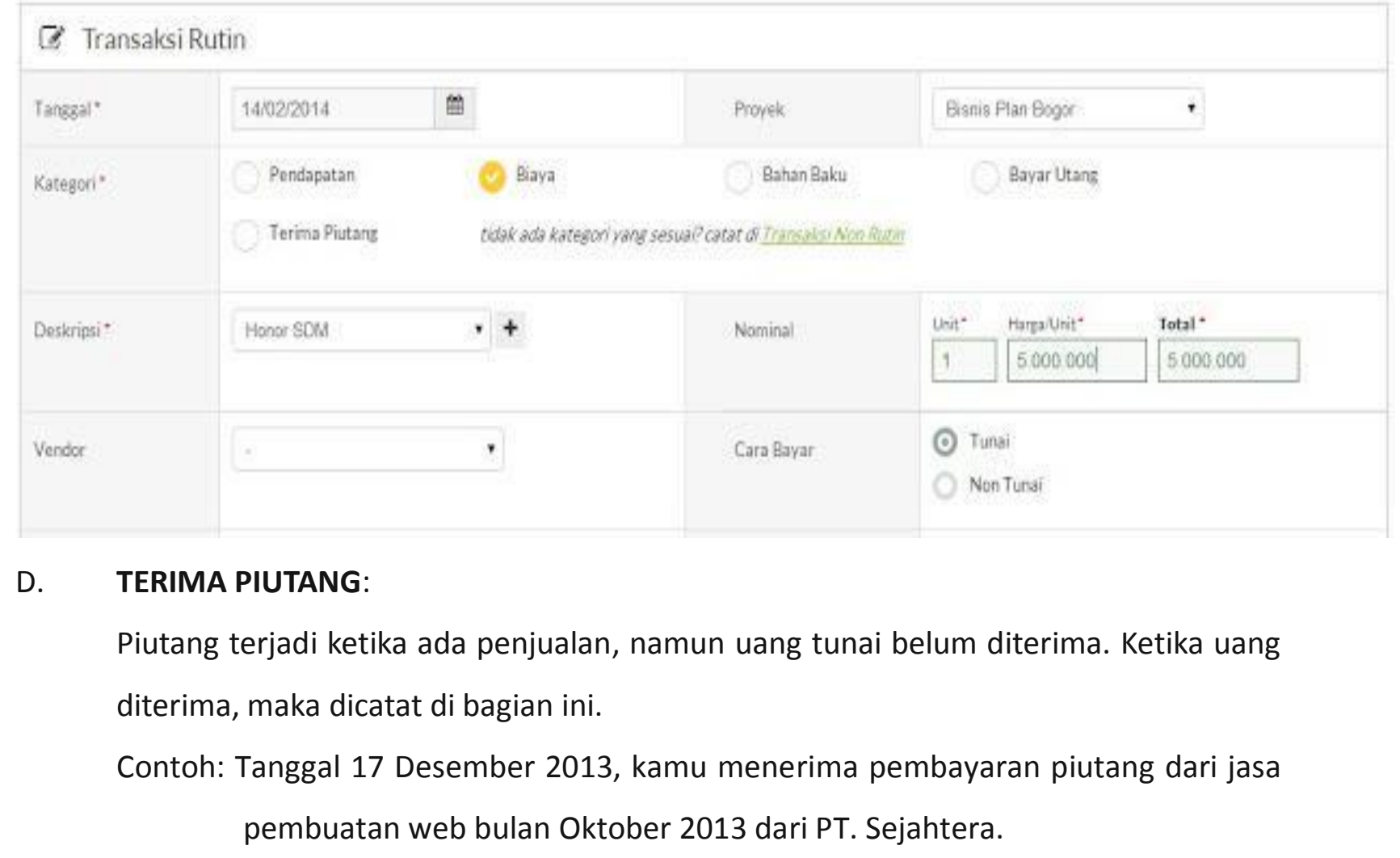




\section{Transaksi Rutin}

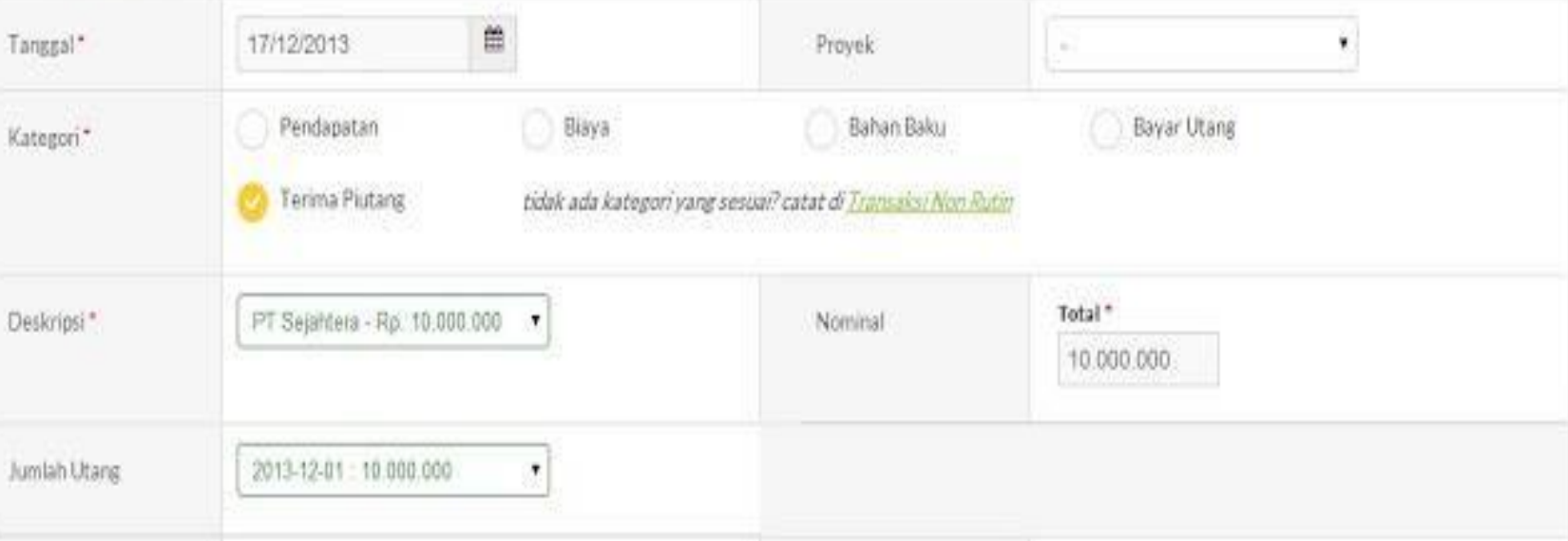

E. BAYAR UTANG :

Utang terjadi ketika kamu membeli sesuatu, namun belum dibayar tunai. Atau terjadi ketika kamu meminjam uang ke Bank atau pihak lain.

Contoh: Tanggal 20 Desember 2013, Distromu melunasi tagihan pembelian katun kombat dari Toko Sakura sebesar Rp 650.000.

Transaksi Rutin

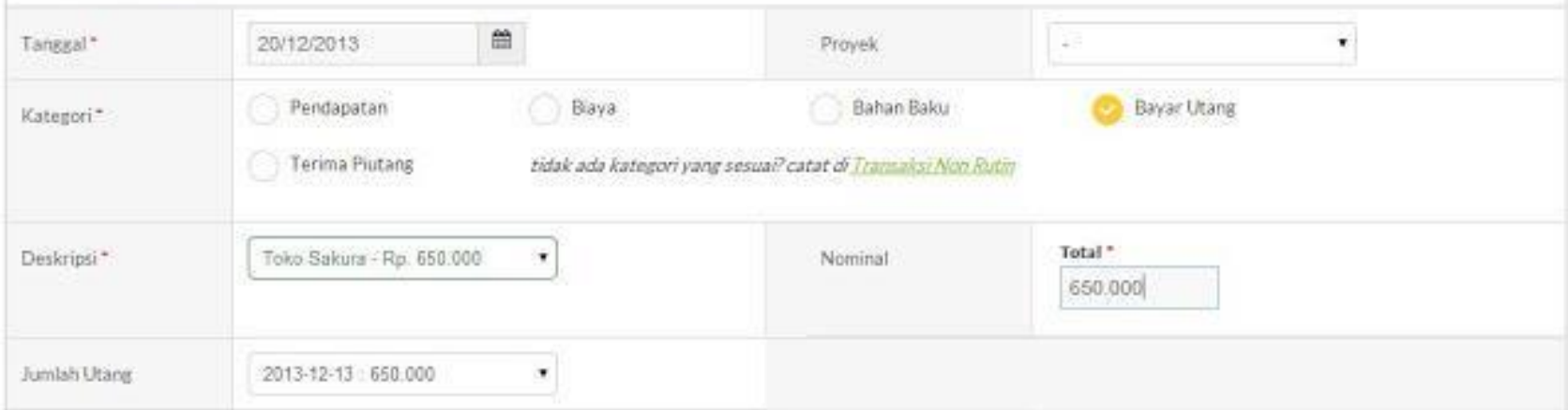

\section{TRANSAKSI NON RUTIN}

\section{F. PERALATAN:}

Adalah alat atau barang yang kamu gunakan dalam proses produksi atau pendukung operasional. Misalnya: komputer, peralatan masak (untuk resto), peralatan tukang dll. Contoh: Pada tanggal 21 Desember, kamu membeli 2 unit Komputer baru untuk peralatan kantor sebesar @Rp 4.000.000, yang diperkirakan umur ekonomis/masa pakainya 4 (empat) tahun. 


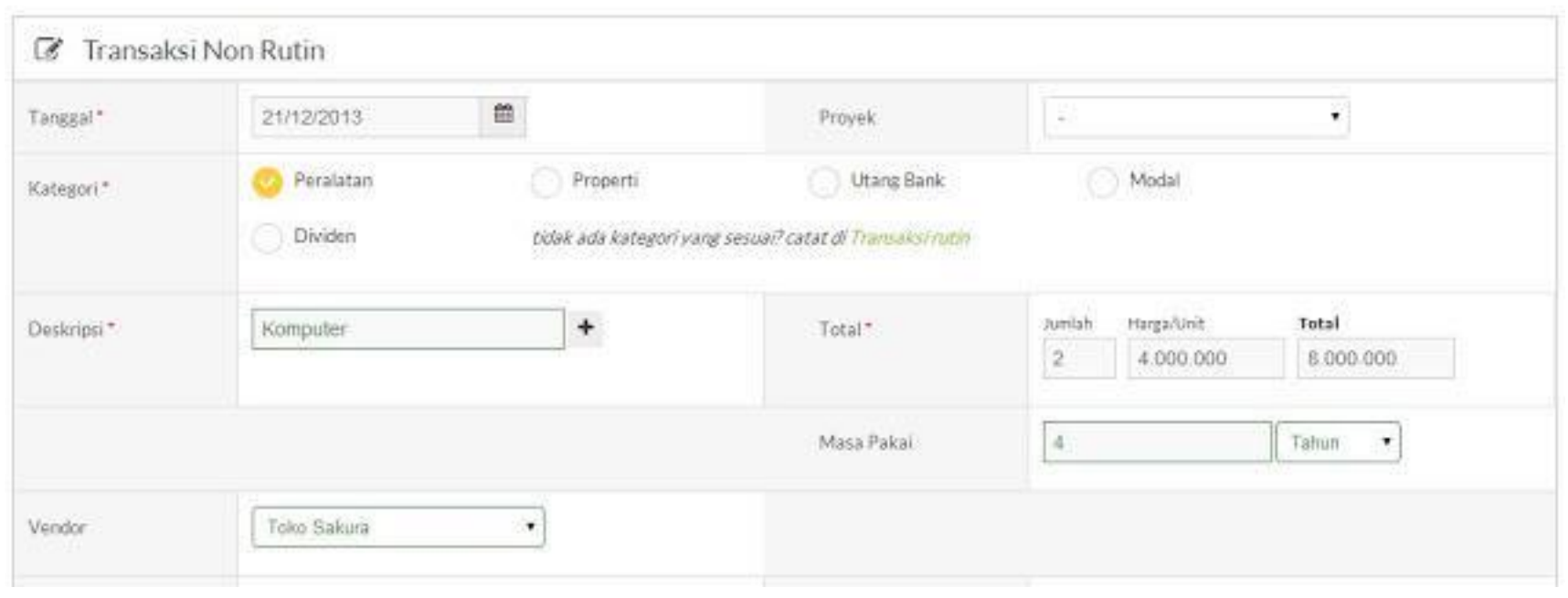

\section{G. PROPERTI :}

Adalah bangunan dan tanah yang kamu sewa atau miliki, yang digunakan dalam operasional.

Contoh: Pada tanggal 22 Desember 2013, kamu menyewa Ruko di Jl. Kartini sebesar Rp 40.000.000 selama 2 tahun (atau Rp 20.000.000/tahun).

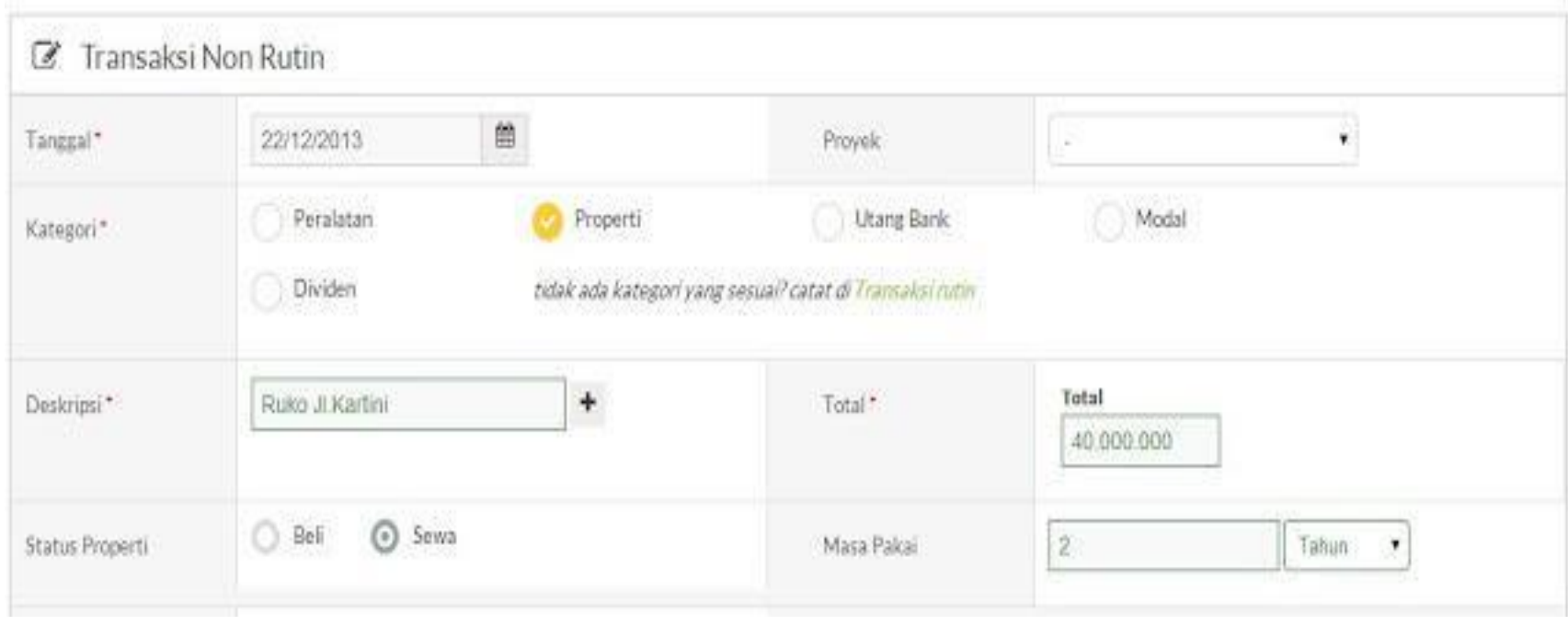

\section{H. UTANG BANK/INVESTOR:}

Apabila kamu meminjam uang pada Bank atau Investor lain, yang harus diangsur pengembaliannya, plus biasanya dikenakan bunga pinjaman.

Contoh: Tanggal 23 Desember 2013, kamu meminjam uang ke BCA untuk menambah modal sebesar Rp 50.000.000. 


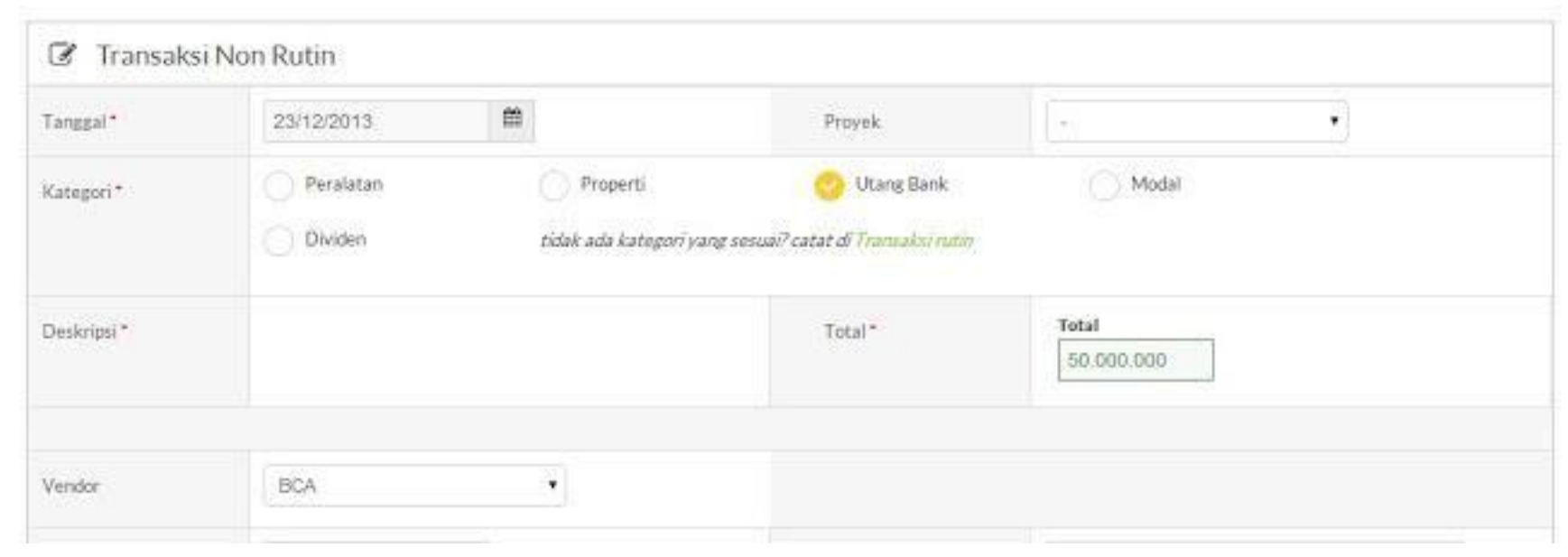

\section{MODAL :}

Uang ataupun aset yang diinvestasikan dalam perusahaan, dan diberikan imbalan saham/kepemilikan kepada yang bersangkutan.

Contoh: Tanggal 25 Desember 2013, rekan kamu bernama Badu memasukkan modal sebesar Rp 20.000.000.

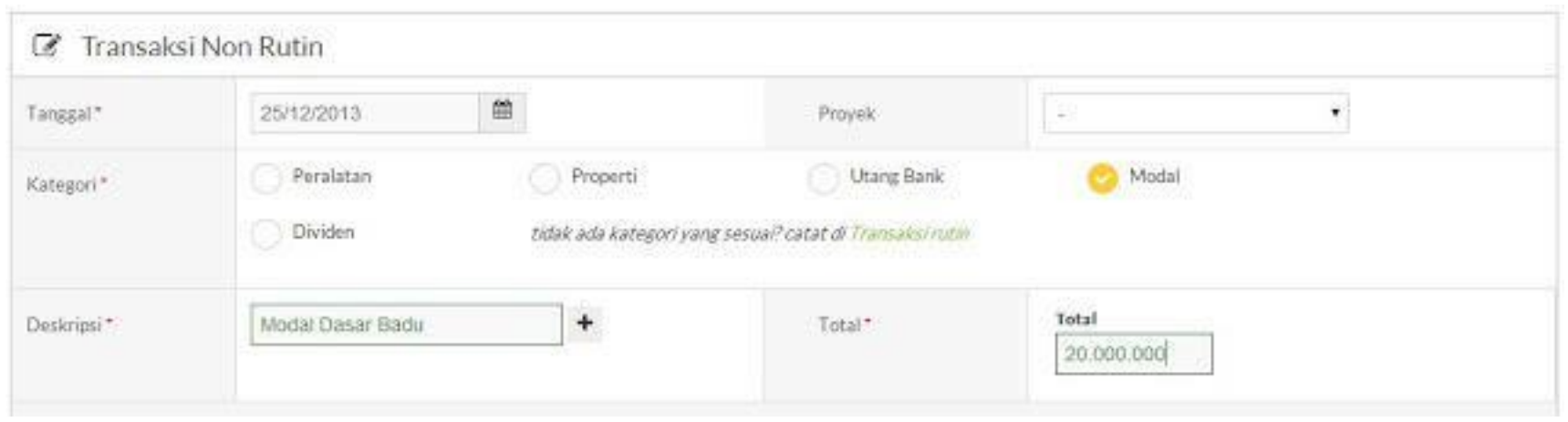

\section{J. DIVIDEN/PRIVE:}

Sebagian uang perusahaan ataupun bagian keuntungan yang diambil pribadi pemilik. Contoh: Pada tanggal 29 Desember 2013, karena suatu hal Badu meminta ijin untuk boleh mengambil prive dari bisnis kalian sebesar Rp 250.000 .

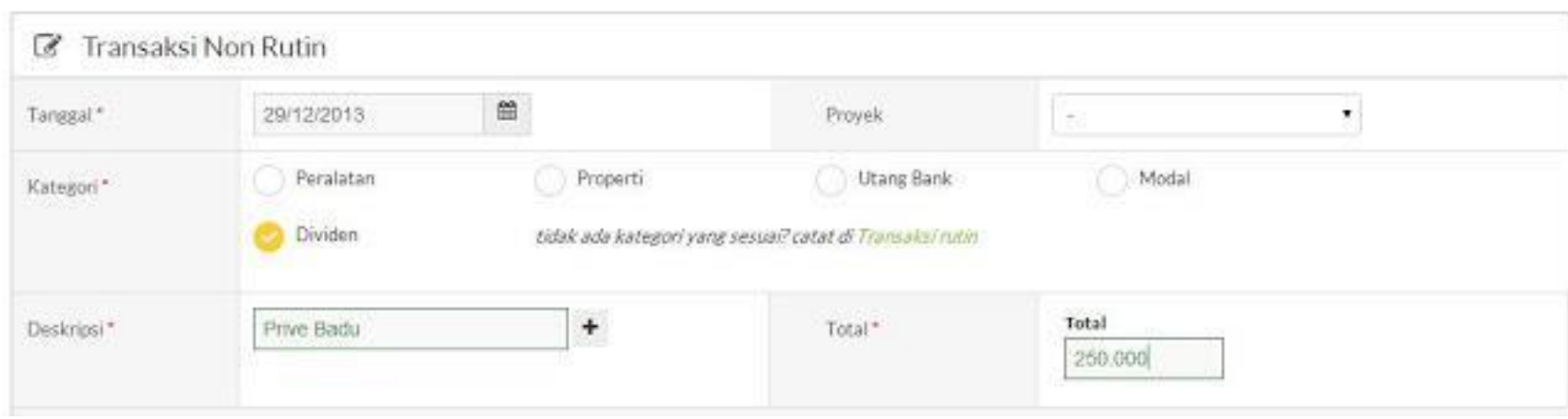




\section{K. HPP/ Bahan Baku Terpakai:}

HPP (Harga Pokok Produksi) adalah bahan baku yang sudah terpakai atau terjual. AkuntingMudah menggunakan metode periodik bulanan serta Harga Rata-Rata, karena menurut kami ini adalah cara yang relatif mudah namun akurat dalam menentukan HPP.

HPP dihitung dengan rumus $=($ Stok Awal+Stok Masuk- Stok Akhir $) \times$ Harga Rata-Rata. Contoh:Tanggal 31 Desember 2013, kamu menghitung sisa akhir bahan baku untuk menentukan HPP bulan Desember 2013, dimana Beras yang tersisa tinggal 75 $\mathrm{kg}$, daging ayam sisa 21 ekor.

\begin{tabular}{|l|l|c|c|c|c|c|c|l|}
\hline No & Bhn Baku & Satuan & Stok Awal & Stok Masuk & Total Stok & Stok Akhir & Harga Rata2 & HPp \\
\hline 1 & Beras & $\mathrm{Kg}$ & 0 & 256 & 256 & 75 & $\operatorname{Rp~7.600}$ & $\operatorname{Rp~1.375.600}$ \\
\hline 2 & Daging Ayam & ekor & 0 & 120 & 120 & 21 & $\operatorname{Rp~20.500}$ & $\operatorname{Rp~2.029.500}$ \\
\hline \multicolumn{9}{|l|}{} \\
\hline
\end{tabular}

Apabila seluruh contoh transaksi di atas dikerjakan dengan benar, maka akan menghasilkan Daftar Transaksi atau disebut juga Jurnal Umum seperti di bawah ini.

\begin{tabular}{|c|c|c|c|c|c|c|c|c|}
\hline TGL & PROYEK & KATEGORI & DESKRIPSI & DEBIT & KREDIT & SALDO & NOTA & \\
\hline 2013-12-01 & Pembustan Wiob & $\begin{array}{l}\text { Pendapatan } \\
\text { Pistare Dasare }\end{array}$ & Jasa Pembuatan Web(PT Sejahtera) & 10.000 .000 & 10.000 .000 & 0 & No image & 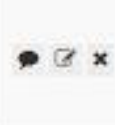 \\
\hline $2013 \cdot 12 \cdot 13$ & - & $\begin{array}{l}\text { Bahan Baku } \\
\text { Utare Dozare }\end{array}$ & Katun Combat Puth froko Sakural & 750.000 & 650.000 & -100000 & No image & - $\cos x$ \\
\hline $2013 \cdot 12 \cdot 17$ & * & Terima Pintang & Jass Pembuatan Web (pT Sejahtera) & 10.000000 & - & 9.900 .000 & No image & $\rightarrow \mathbb{B} x$ \\
\hline $2013 \cdot 12 \cdot 20$ & $*$ & Bayar Otans & Katun Combat Putih [Toko Sakural & *. & 650,000 & 9.250 .000 & Noimage & $9 \mathbb{2} \times$ \\
\hline $2013 \cdot 12 \cdot 21$ & - & Peralatan & Kompueer (Toko Sakura) & - & 8.000 .000 & $1.250,000$ & Noimage & - $8 \times$ \\
\hline $2013 \cdot 12 \cdot 22$ & . & Propertí & Ruvo / Kartini (Pak Rama) & - & 40.000000 & -38.750000 & Noimage & $=0 \times$ \\
\hline $2013-12-23$ & . & Utang Bark & $(\mathrm{BCA})$ & & & 11250.000 & No image & $9 \square \times$ \\
\hline $2013-12-25$ & - & Modal & Modal Dasar Eadu & 20.000 .000 & - & 31.250 .000 & No image & - $\varangle \times$ \\
\hline $2013-12-29$ & - & Dividen & Prive Badu & - & 250.000 & 31000000 & No image & - $\cos \times$ \\
\hline
\end{tabular}

Output yang paling penting dari seluruh contoh aktifitas yang Anda lakukan di atas adalah Laporan Keuangan, yang terdiri dari Neraca, Laba Rugi, Dividen, dan Arus Kas. Laporan ini 
akan dihasilkan secara otomatis dan riil time.

\section{Modul I}

13.Pembiayaan KUR Penjelasan Umum Modul

13. Pembiayaan KUR

13.1.1. Pemahaman Umum tentang Pembiayaan KUR

13.1.2. Pemahaman tentang manfaat KUR

13.1.3. Pemahaman tentang syarat-syarat KUR

Output:

a) Peserta paham tentang mekanisme pembiayaan dengan menggunakan Kredit Usaha Rakyat

b) Peserta paham tentang manfaat KUR

c) Peserta paham tentang syarat-syarat untuk mengajukan KUR 
d) Peserta paham tentang prosedur pengajuan KUR

Estimasi durasi untuk mengerjakan secara mandiri: 1-3 jam

Dukungan yang dibutuhkan:

o Pendampingan Mentor untuk membahas kelengkapan prasyarat KUR

o Membahas bersama UKM lain, kesiapan untuk mengakses permodalan KUR

\section{Lembar Kerja Modul Pembiayaan KUR}

Sebelum kita mulai, apakah Anda sudah tahu perbedaan antara berbagai tipe permodalan berikut?

\begin{tabular}{l|l|}
\hline Jenis Permodalan Sumber Pengembalian \\
\hline Hibah \\
\hline Pinjaman \\
\hline Permodalan / penyertaan modal \\
\hline
\end{tabular}

Coba menuliskan apa yang Anda tahu dalam waktu 5 menit!

Setelah menulis jawaban Anda, silakan lanjut ke halaman berikutnya.

Jenis Permodalan Sumber Pengembalian
Hibah
Lembaga sosial/agama
Keluarga terdekat Tokoh masyarakat/agama

110 Kemendagri - sylabus - 2018 


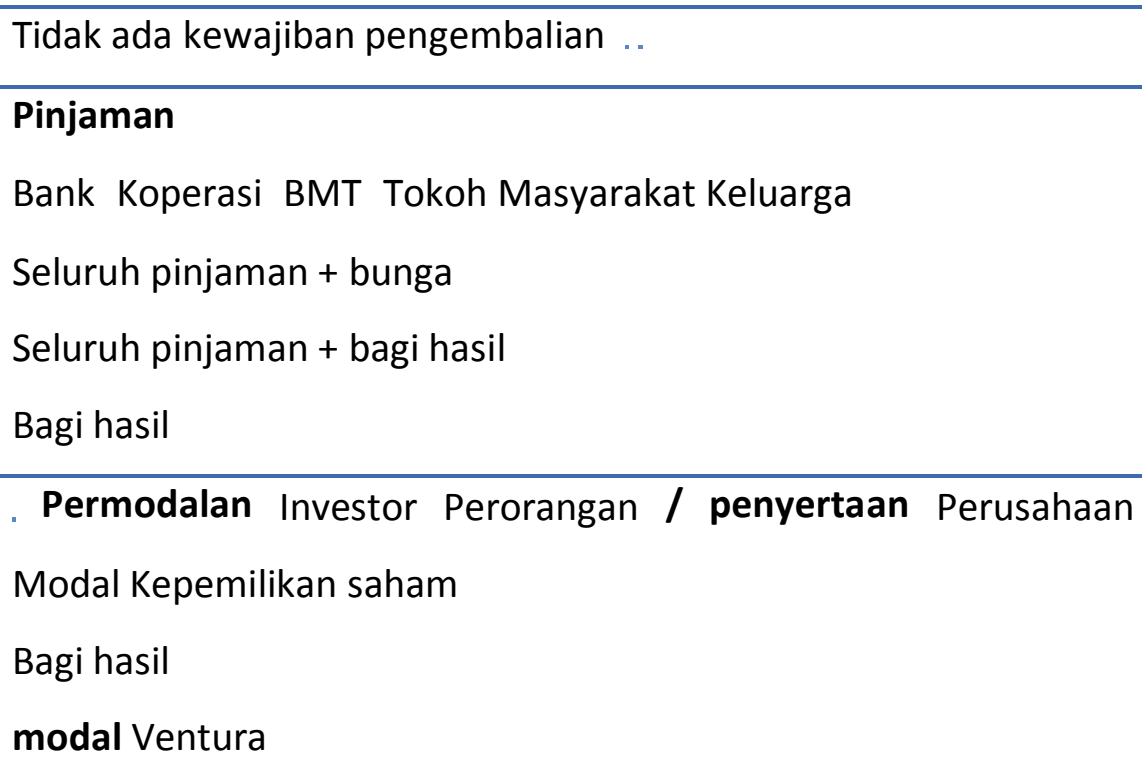

Pada modul ini Anda akan belajar lebih jauh tentang pembiayaan berbasis pinjaman, khususnya Kredit Usaha Rakyat.

Kredit Usaha Rakyat (KUR) adalah program dari pemerintah berupa pinjaman modal usaha yang dananya $100 \%$ dari bank pelaksana KUR untuk rakyat Indonesia yang produktif dan layak namun belum siap untuk menerima pinjaman komersil.

Kriteria Produktif dan layak adalah:

o Usaha yang menghasilkan barang atau jasa yang memberi nilai tambah bagi pelaku usaha, o Usaha yang keuntungannya bisa membayar kewajiban pokok kredit, o Jenis usahanya dinilai belum layak mendapat kredit di bank.

Jika usaha Anda memenuhi 3 kriteria ini, maka Anda layak menerima pinjaman program KUR. Nilai pinjaman maksimal untuk program KUR adalah sampai dengan maksimal Rp. $500.000 .000,00$ (lima ratus juta rupiah).

Ada 33 Bank Nasional, Bank Daerah dan Swasta yang menjadi mitra pemerintah untuk program KUR ini.

Jadi karena KUR ini termasuk kategori Pinjaman, jelas ada kewajiban bagi Anda bila berhasil menjadi penerima KUR. Kewajiban pengembaliannya adalah berupa cicilan nilai pinjaman dan bunga per tahun.

Sejak Januari 2016, suku bunga pinjaman KUR adalah 9\% (Sembilan Persen) efektif per tahun 
dari sebelumnya 12\% (Dua Belas Persen).

\section{Prasyarat Mengajukan KUR}

o Identitas diri nasabah, seperti KTP, SIM, Kartu Keluarga, dll.

o Legalitas usaha, seperti akta pendirian, akta perubahan

o Perizinan usaha, seperti SIU, TDP, SK Domisili, dII

o Catatan pembukuan atau laporan keuangan

Berikut adalah tahapan pengajuan Pinjaman KUR secara umum:

Lokasi Usaha

Pengajuan Permohonan Kredit

Pengecekan Kelengkapan Usaha

Survey Lokasi Usaha

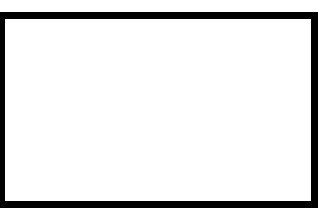

Analisa Kelayakan Usaha

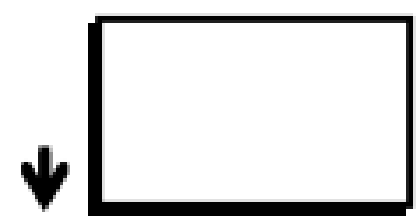

Akad Kredit

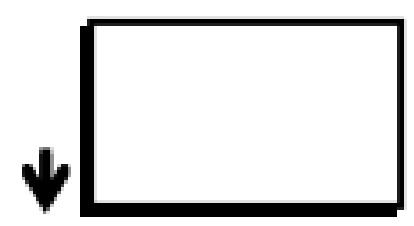

112 Kemendagri - sylabus - 2018 
Pencairan Kredit

\section{Manfaat mengakses KUR}

a) Tambahan modal untuk mengembangkan usaha namun belum ada barang/aset yang bisa dijaminkan

b) Mendapatkan fasilitas pinjaman dengan bunga efektif yang rendah ( $9 \%$ per tahun), di bawah tingkat suku bunga komersil

c) Mengambil kesempatan terdaftar di bank nasional, daerah atau Swasta, sehingga memperbesar peluang mendapatkan fasilitas pembiayaan lainnya. Selamat Anda sudah menyelesaikan Modul ini. Setelah mengerjakan Modul ini, Anda seharusnya sudah:

o Memahami apa itu Kredit Usaha Rakyat

o Memahami manfaat Kredit Usaha Rakyat o Memahami prasyarat pengajuan Kredit Usaha Rakyat

o Memahami prosedur/tahapan pengajuan Kredit Usaha Rakyat

Bila ada yang belum anda pahami dan, mohon tandai dengan ' $x$ 'di daftar di atas. Tuliskan di kotak bawah, hal-hal yang masih Anda anggap kurang jelas atau Anda ingin ketahui lebih lanjut:

Lalu hubungi TIM Pendamping terdekat. 


\section{MODUL I}

\section{Pengenalan Pajak Untuk UKM}

Meski usaha yang sekarang kita geluti hanya berskala kecil hingga menengah, kewajiban bayar pajak tetap ada. Ketentuan ini diatur dalamPeraturan Pemerintah Nomor 46 Tahun 2013 tentang Pajak Penghasilan Atas Penghasilan dari Usaha yang diterima atau diperoleh Wajib Pajak yang Memiliki Peredaran Bruto Tertentu. Tapi, beda dengan wajib pajak lainnya, pelaku usaha kecil atau menengah membayar pajak berdasarkan total penjualan. Hitung-hitungannya juga tidak serumit wajib pajak lain.

\section{"Rumus PPhUKM : $1 \% \times$ total penjualan "}

Pelaku UKM yang dikenai pajak ini maksimal omzetnya Rp 4,8 miliar dalam setahun. Kalau lebih dari itu, perhitungan pajak beda lagi karena sudah tidak digolongkan sebagai UKM

Yang tidak termasuk wajib pajak dalam Peraturan Pemerintah No 46/2013 ini adalah: Orang yang usahanya: 
a. Menggunakan sarana/prasarana yang bisa dibongkar- pasang baik menetap maupun tidak menetap.

b. Menggunakan sebagian/seluruh tempat umum yang sejatinya tidak boleh dipakai untuk berjualan.

Contoh: asongan, warungtenda, PKL

Wajib pajak badan:

a. Yang belum beroperasi secara komersial

b. Yang dalam kurun 1 (satu) tahun setelah beroperasi secara komersial mendapat peredaran bruto lebih dari Rp. 4,8 miliar.

Contoh: pengusaha bengkel baru buka setahun, omzetnya setahun langsung Rp. 6 miliar.

Yang juga perlu digarisbawahi dalam PP No. 46/2013 adalah dasar pengenaan pajak penghasilan yaitu peredaran bruto tiapbulan. Untuk lebih jelasnya, mari kita lihat simulasi pajak UKM berikut ini :

\section{Simulasi Pajak UKM}

Rinciannya: Januari Rp. 15 juta Februari Rp. 11 juta Maret Rp. 13 juta April Rp. 16 juta Mei Rp. 15 juta Juni Rp. 11 juta Juli Rp. 10 juta Agustus Rp. 8 juta September Rp. 15 juta Oktober Rp. 13 juta November Rp. 17 juta

Pak Joko punya usaha jasa servis dan perakitan elektronik. Usahanya sudah berlangsung 3 tahun dengan omzet setahun terakhir Rp.160 juta.

Desember Rp. 16 juta Jadi, pajak penghasilan UKM Pak Joko untuk bulan Januari sebesar 1\% x Rp. 15 juta = Rp. 150 ribu. Pajak penghasilan pada Februari adalah $1 \%$ xp. 11 juta = Rp. 110 ribu. Demikian seterusnya.

Omzet per bulan dikalikan $1 \%$.

Total pajaknya selama setahun adalah Rp 1,6 juta.

\section{Latihan:}


Simulasikan penghasilan / penjualan usaha anda untuk 12 bulan di tahun ini

\section{Modul I}

15.Kontribusi (Pembagian Kerja)

\section{Penjelasan Umum Modul}

15. Modul Standar Pembagian Kerja (Kontribusi)

15.1.1. Pemahaman Umum Pembagian Kerja

15.1.2. Manfaat Pembagian Kerja

15.1.3. Praktik penyusunan Pembagian Kerja

Output:

o Peserta sadar pentingnya memiliki pembagian kerja 
o Peserta memahami apa itu pembagian kerja o Peserta memahami langkah-langkah umum pembagian kerja

Estimasi durasi untuk mengerjakan secara mandiri : 1-4 jam

Dukungan yang dibutuhkan:

o Pendampingan Mentor untuk penyusunan pembagian kerja, setelah mencoba mengerjakan secara mandiri

o Membahas bersama UKM lain, Pembagian Kerja masing-masing

\section{Lembar Kerja Modul 1}

\section{1 Kontribusi/Pembagian Kerja}

Sebelum kita mulai, coba Anda tuliskan di kotak bawah ini, apa yang Anda bayangkan bila mendengar kata "Kontribusi"

Menurut saya, Kontribusi (pembagian kerja) adalah:

Setelah menulis jawaban Anda, silakan lanjut ke halaman berikutnya.

\section{Lembar Kerja Modul}

\subsection{Manfaat Pembagian Kerja}

Dalam Modul ini, kita juga akan belajar tentang bagaimana menyusun pembagian kerja agar seluruh perangkat usaha (organisasi) bisa menjalankan tugas dan tanggung jawabnya dengan baik.

Apa manfaatnya bagi Anda, bila Anda menyusun Pembagian Kerja? Suatu usaha (organisasi) 
yang memiliki penyusunan pembagian kerja tentunya bisa mendapatkan manfaat sebagai berikut:

- Kejelasan pekerjaan dan tanggung jawab bagi setiap orang di setiap unit usaha

- Perencanaan dan perbaikan kinerja

- Dasar perencanaan pelatihan dan pengembangan keterampilan

- Dasar rekrutmen

- Pengembangan unit usaha secara keseluruhan dan berkesinambungan Sehingga, jelas bahwa manfaatnya adalah sebagai dasar pengembangan usaha (organisasi) untuk mencapai hasil kerja yang efektif dan efisien.

\section{Lembar Kerja Modul}

\subsection{Praktik Penyusunan Pembagian Kerja}

Agar modul ini bisa efektif membantu Anda memahami dan mencoba menyusun pembagian kerja pada unit usaha Anda, sebaiknya kita fokuskan pembahasan pada 1 produk/jasa yang Anda hasilkan.

Langkah-langkah untuk dapat menyusun pembagian kerja (kontribusi) untuk usaha adalah:

1. Menentukan alur kerja pada unit usaha

2. Menurunkan alur kerja menjadi pembagian kerja

3. Menuliskan pembagian kerja di dalam format

4. standar

Silakan tuliskan di bawah,apa Produk atau Jasa yang Anda akan fokuskan untuk kita bahas penetapan alur kerjanya:

Produk / Jasa yang Saya akan fokuskan untuk penetapan alur kerjanya adalah:

Baiklah, sekarang setiap kali kita membahas tentang alur kerja dan kontribusi (pembagian kerja), Anda harus fokus membayangkan tentang Produk/Jasa yang Anda tuliskan di atas ya. Alur Kerja adalah proses kerja yang dibutuhkan untuk menghasilkan suatu produk/jasa. Penyusunan alur kerja ini dimulai dengan cara menuliskan pekerjaan apa saja yang perlu dikerjakan, meliputi: 
Mari kita coba dengan contoh agar penyusunan alur kerja di atas dapat lebih mudah untuk dipahami. Misalnya saya memiliki unit usaha untuk menjual kembali (reseller) makanan dendeng balado siap saji, maka penyusunan alur kerjanya adalah sebagai berikut:

\begin{tabular}{|l|l|}
\hline Elemen Alur Kerja & Penjabaran \\
\hline \multirow{3}{*}{ Input } & 1. Data supplier dendeng balado \\
& 2. Data pembeli \\
& 3. Harga pasaran \\
\hline
\end{tabular}

\begin{tabular}{|c|c|}
\hline Peralatan & $\begin{array}{l}\text { 1. Sistem pemesanan } \\
\text { 2. Sistem pengepakan/pembungkusan } \\
\text { 3. Sistem pembayaran } \\
\text { 4. Sistem pengiriman } \\
\text { 5. Sistem pembukuan sederhana untuk pencatatan } \\
\text { pembelian }\end{array}$ \\
\hline Sumber Daya Manusia & $\begin{array}{l}\text { (1) Keahlian menggunakan sosial media sebagai media iklan } \\
\text { yang gratis } \\
\text { (2) Kemampuan menerima pesanan dari beberapa media } \\
\text { (telepon, sms, whatsapp, dll) } \\
\text { (3) Kemampuan pembukuan sederhana }\end{array}$ \\
\hline Aktivitas & $\begin{array}{l}\text { 1. Menghubungi supplier/pembuat dendeng balado siap saji } \\
\text { untuk menerima pesanan } \\
\text { 2. Menerima pemesanan dari pelanggan } \\
\text { 3. Merekap pesanan } \\
\text { 4. Merekap pembayaran } \\
\text { 5. Membungkus pesanan } \\
\text { 6. Mengirimkan pesanan } \\
\text { 7. Menerima masukan dari pembeli (apabila ada) }\end{array}$ \\
\hline Output & Jasa penjualan kembali (reseller) dendeng balado siap saji \\
\hline
\end{tabular}

Kita coba sekali lagi dengan contoh penyusunan alur kerja untuk usaha mencukur rambut (jasa).

\begin{tabular}{|l|ll|}
\hline Elemen Alur Kerja & Penjabaran \\
\hline Input & Gaya/contoh potongan rambut \\
\hline \multirow{2}{*}{ Peralatan } & 5. & Gunting \\
& 6. & Pisau cukur \\
\hline
\end{tabular}




\begin{tabular}{|c|c|c|}
\hline & $\begin{array}{l}7 . \\
8 . \\
9 . \\
10 . \\
11 . \\
12 . \\
13 . \\
14 . \\
15 .\end{array}$ & $\begin{array}{l}\text { Kursi } \\
\text { Cermin } \\
\text { Celemek } \\
\text { Tissue } \\
\text { Shampo } \\
\text { Tempat cuci rambut } \\
\text { Handuk } \\
\text { Krim rambut } \\
\text { Ruangan cukur }\end{array}$ \\
\hline Sumber Daya Manusia & \multicolumn{2}{|c|}{$\begin{array}{l}\text { Tukang cukur (ahli mencukur rambut) } \\
\text { Kasir (kemampuan pembukuan sederhana) }\end{array}$} \\
\hline Aktivitas & \multicolumn{2}{|c|}{$\begin{array}{l}\text { Menyambut tamu } \\
\text { Menanyakan gaya potongan rambut } \\
\text { Menyiapkan peralatan (memasang kain penutup, menyiapkan } \\
\text { gunting, dII) } \\
\text { Proses mencukur dilakukan } \\
\text { Mencukur selesai } \\
\text { Proses membersihkan sisa rambut di pelanggan } \\
\text { Pelanggan membayar jasa } \\
\text { Pelanggan selesai dan keluar } \\
\text { Membersihkan bekas potongan rambut di kursi dan lantai } \\
\text { Siap menerima pelanggan baru }\end{array}$} \\
\hline
\end{tabular}

\begin{tabular}{|l|l|}
\hline Output & |Jasa cukur rambut dengan kapasitas 3 kursi \\
\hline
\end{tabular}

Nah, sekarang silakan Anda coba menyusun alur kerja untuk produk/jasa yang sudah Anda pilih sebelumnya. Silahkan diisi sedetil/selengkap mungkin yang Anda bisa.

\begin{tabular}{|l|l|}
\hline Elemen Alur Kerja & Penjabaran \\
\hline Input & \\
\hline Peralatan & \\
\hline Sumber Daya Manusia & \\
\hline
\end{tabular}

Aktivitas 
Output

Jika pada bagian ini, Anda merasa kesulitan, silakan berdiskusi dengan Pendamping di Rumah

Kreatif BUMN. Jika sudah selesai, apa yang Anda tulis pada bagian ini, adalah Alur Kerja

Produk atau Jasa Anda.

Baiklah, sekarang Anda sudah memahami apa itu Alur Kerja, dan sudah berupaya menyusun

Alur Kerja bagi Produk/Jasa Anda!

Tantangan yang Anda hadapi setelah ini adalah untuk membuat pembagian kerja berdasarkan

Alur Kerja yang sudah Anda susun.

Selamat! Ini langkah awal Anda untuk bisa menyusun kontribusi (pembagian kerja) di unit usaha Anda.

Setelah mengerjakan Modul ini, Anda seharusnya sudah:

o memahami apa itu Kontribusi (Pembagian Kerja)

o sadar manfaat memiliki Pembagian Kerja

o memahami langkah-langkah umum untuk membuat alur kerja, dan

o mampu menyusun alur kerja

\begin{tabular}{|c|c|c|}
\hline \multirow{6}{*}{ Aktivitas } & Menghubungi & \multirow{5}{*}{$\begin{array}{l}\text { Kontak dan pencatatan } \\
\text { 1. Menghubungi supplier } \\
\text { /pembuat dendeng } \\
\text { balado siap saji untuk } \\
\text { menerima pesanan } \\
\text { 2. Menerima pesanan dari } \\
\text { pelanggan } \\
\text { 3. Merekap pesanan } \\
\text { 4. Konfirmasi pembayaran dar } \\
\text { pembukuan }\end{array}$} \\
\hline & $\begin{array}{l}\text { supplier/pembuat dendeng } \\
\text { balado siap saji untuk } \\
\text { menerima pesanan }\end{array}$ & \\
\hline & $\begin{array}{l}\text { Menerima pemesanan dari } \\
\text { pelanggan }\end{array}$ & \\
\hline & Merekap pesanan & \\
\hline & Merekap pembayaran & \\
\hline & Membungkus pesanan & $\begin{array}{l}\text { Pengiriman } \\
\text { Membungkus pesanan yang } \\
\text { sudah dibayar oleh pelanggan }\end{array}$ \\
\hline
\end{tabular}

Bila ada yang belum anda pahami, mohon tandai dengan ' $x$ ' di daftar di atas. Tuliskan di kotak bawah, hal-hal yang masih Anda anggap kurang jelas atau Anda ingin ketahui lebih lanjut: Lalu hubungi TIM Pendamping terdekat. 
Pertanyaan- pertanyaan

saya:

Sekarang kita akan melanjutkan langkah kedua dalam menyusun pembagian kerja (kontribusi), yaitu: menurunkan alur kerja menjadi pembagian kerja. Inti dari kegiatan ini adalah membuat pembagian kerja agar lebih jelas. Agar lebih mudah, kita bisa fokus pada aktivitas-aktivitas yang sudah Anda tuliskan pada kolom Alur Kerja.

Mari kita lihat kembali contoh berikut:

\begin{tabular}{|c|c|c|}
\hline \multirow{5}{*}{ aktivitas } & Menyambut tamu & \multirow{5}{*}{$\begin{array}{l}\text { Proses cukur: } \\
\text { 1. Mempersilahkan duduk di kursi cukur } \\
\text { 2. Menanyakan gaya potongan rambut } \\
\text { 3. Menyiapkan peralatan (memasang kain penutup, } \\
\text { menyiapkan gunting, dll) } \\
\text { 4. Cukur dilakukan } \\
\text { 5. Cukur selesai } \\
\text { 6. Membersihkan sisa-sisa rambut di kepala dan } \\
\text { tubuh pelanggan }\end{array}$} \\
\hline & $\begin{array}{l}\text { Menanyakan gaya potongan } \\
\text { rambut }\end{array}$ & \\
\hline & $\begin{array}{l}\text { Menyiapkan peralatan (memasang } \\
\text { kain penutup, menyiapkan gunting, } \\
\text { dII) }\end{array}$ & \\
\hline & Proses mencukur dilakukan & \\
\hline & Mencukur selesai & \\
\hline
\end{tabular}

Usaha: Jasa penjualan kembali (reseller) dendeng balado siap saji

\begin{tabular}{|l|l|l|}
\hline & & $\begin{array}{l}\text { 1. Mengirimkan pesanan sesuai dengan alamat } \\
\text { pelanggan }\end{array}$ \\
& Menerima masukan dari pembeli & 2. Hubungan Pelanggan \\
(apabila ada) & $\begin{array}{l}\text { a. Konfirmasi pengiriman } \\
\text { b. Menerima masukan dari pembeli/pelanggan } \\
\text { (bila ada) }\end{array}$ \\
\hline
\end{tabular}

Untuk contoh di atas, kita bisa mengelompokkan ada 3 aktivitas utama dari alur kerja tersebut. Agar lebih jelas lagi, mari kita lihat contoh selanjutnya.

Usaha: Jasa Cukur Rambut (kapasitas: 3 kursi cukur)

\begin{tabular}{|l|l|l|}
\hline \multirow{2}{*}{$\begin{array}{l}\text { Proses membersihkan sisa rambut } \\
\text { di pelanggan }\end{array}$} & \\
\cline { 2 - 3 } & Pelanggan membayar jasa & Kasir: \\
\cline { 2 - 3 } & Pelanggan selesai dan keluar & $\begin{array}{l}\text { 1. Menyiapkan tanda bukti pembayaran } \\
\text { 2. Menerima pembayaran }\end{array}$ \\
& 3. Merekap pembayaran ke pembukuan \\
\hline
\end{tabular}




\begin{tabular}{|l|l|l|}
\hline & & 4. Mengucapkan terima kasih \\
\cline { 2 - 3 } & $\begin{array}{l}\text { Membersihkan bekas potongan } \\
\text { rambut di kursi dan lantai }\end{array}$ & $\begin{array}{l}\text { Bagian kebersihan: } \\
\text { 1. Membersihkan sisa-sisa potongan rambut di kursi } \\
\text { dan lantai }\end{array}$ \\
\cline { 2 - 3 } & Siap menerima pelanggan baru & $\begin{array}{l}\text { 2. Menyilahkan pelanggan selanjutnya untuk duduk } \\
\text { di kursi cukur }\end{array}$ \\
\hline
\end{tabular}

Pada contoh di atas, terdapat 3 pembagian kerja utama. Sekarang tugas Anda adalah untuk menurunkan aktivitas pada alur kerja yang sudah Anda buat sebelumnya menjadi pembagian kerja seperti pada contoh pada halaman selanjutnya.

Tuliskan pembagian kerja yang Anda buat pada lembar berikut.

Usaha:

aktivitas

Bila ada yang ingin Anda diskusikan, silakan hubungi Pendamping Anda. Kita akan membahas langkah ketiga agar pembagian kerja (kontribusi) usaha Anda dapat segera diselesaikan. Langkah tersebut adalah menuliskan pembagian kerja di dalam format standar.

Anda tidak perlu khawatir, karena kita akan membuat format penulisan pembagian kerja tersebut dalam bentuk sesederhana mungkin. Dokumen ini pada nantinya akan sangat membantu Anda apabila usaha Anda semakin besar dan membutuhkan pengembangan. Anda bisa mengikuti format penulisan berikut ini atau mengikuti format lainnya yang Anda rasa lebih nyaman.

Dalam menuliskan pembagian kerja ini, kita perlu melihat lagi tabel pembagian kerja yang sudah kita susun.

\begin{tabular}{|c|c|c|}
\hline \multirow{7}{*}{ Aktivitas } & $\begin{array}{l}\text { Menghubungi supplier/pembuat } \\
\text { dendeng balado siap saji untye } \\
\text { menerima pesanan }\end{array}$ & \multirow{4}{*}{$\begin{array}{l}\text { Kontak dan pencatatan } \\
\text { 1. Menghubungi supplier/pembuat dendeng balado siap saji untuk menerima } \\
\text { pesanan } \\
\text { 2. Menerima pesanan dari pelanggan } \\
\text { 3. Merekap pesanan } \\
\text { 4. Konfirmasi pembayaran dan pembukuan }\end{array}$} \\
\hline & Menerima pemesanan dari pelanggan & \\
\hline & Merekap pesanan & \\
\hline & Merekap pembayaran & \\
\hline & Membungkus pesanan & \multirow{2}{*}{$\begin{array}{l}\text { Pengiriman } \\
\text { 1. Membungkus pesanan yang sudah dibayar oleh pelanggan } \\
\text { 2. Mengirimkan pesanan sesuai dengan alamat pelanggan }\end{array}$} \\
\hline & Mengirimkan pesanan & \\
\hline & $\begin{array}{l}\text { Menerima masukan dari pembeli } \\
\text { (apabila ada) }\end{array}$ & $\begin{array}{l}\text { Hubungan Pelanggan } \\
\text { 1. Konfirmasi pengiriman } \\
\text { 2. Menerima masukan dari pembeli/pelanggan (bila ada) }\end{array}$ \\
\hline
\end{tabular}

Sebagai contoh pada usaha Jasa penjualan kembali (reseller) dendeng balado siap saji, kita 


\begin{tabular}{|c|c|}
\hline Usaha: & Jasa penjualan kembali (reseller) dendeng balado siap saji \\
\hline Tanggal: & Oktober 2016 \\
\hline Nama Posisi: & Kontak dan Pencatatan \\
\hline $\begin{array}{l}\text { Tugas dan Tanggung } \\
\text { Jawab: }\end{array}$ & $\begin{array}{l}\text { Menghubungi supplier/pembuat dendeng balado siap } \\
\text { saji untuk menerima pesanan } \\
\text { Menerima pesanan dari pelanggan } \\
\text { Merekap pesanan } \\
\text { Konfirmasi pembayaran } \\
\text { Melakukan rekapitulasi pembukuan sederhana setiap } \\
\text { minggu } \\
\text { Melakukan pembayaran kepada supplier sesuai waktu } \\
\text { yang ditentukan }\end{array}$ \\
\hline Keahlian: & $\begin{array}{l}\text { 1. Melakukan pencatatan dengan rapi } \\
\text { 2. Melakukan pembukuan sederhana } \\
\text { 3. Melayani pelanggan } \\
\text { 4. Membina hubungan baik dengan supplier dan } \\
\text { pelanggan }\end{array}$ \\
\hline
\end{tabular}

akan berlatih untuk menuliskan pembagian kerja untuk Kontak dan Pencatatan.

Format penulisan bisa Anda lihat pada halaman selanjutnya. Nah, sudah jelas kan?

Kita coba sekali lagi dengan contoh kedua.

\begin{tabular}{|c|c|c|}
\hline \multirow{8}{*}{ aktivitas } & Menyambut tamu & \multirow{6}{*}{$\begin{array}{l}\text { Proses cukur: } \\
\text { 1.Mempersilahkan duduk di kursi cukur } \\
\text { 2. Menanyakan gaya potongan rambut } \\
\text { 3. Menyiapkan peralatan (memasang kain } \\
\text { penutup, menyiapkan gunting, dll) } \\
\text { 4. Cukur dilakukan } \\
\text { 5. Cukur selesai } \\
\text { 6. Membersihkan sisa-sisa rambut di kepala } \\
\text { dan tubuh pelanggan ... }\end{array}$} \\
\hline & Menanyakan gaya potongan rambut & \\
\hline & $\begin{array}{l}\text { Menyiapkan peralatan (memasang } \\
\text { kain penutup, menyiapkan gunting, } \\
\text { dll) }\end{array}$ & \\
\hline & Proses mencukur dilakukan & \\
\hline & Mencukur selesai & \\
\hline & $\begin{array}{l}\text { Proses membersihkan sisa rambut di } \\
\text { pelanggan }\end{array}$ & \\
\hline & Pelanggan membayar jasa & \multirow{2}{*}{$\begin{array}{l}\text { Kasir: } \\
\text { 1. Menyiapkan tanda bukti pembayaran } \\
\text { 2. Menerima pembayaran } \\
\text { 3. Merekap pembayaran ke pembukuan } \\
\text { 4. Mengucapkan terima kasih } \\
\end{array}$} \\
\hline & Pelanggan selesai dan keluar & \\
\hline & $\begin{array}{l}\text { Membersihkan bekas potongan } \\
\text { rambut di kursi dan lantai }\end{array}$ & \multirow{2}{*}{$\begin{array}{l}\text { Bagian kebersihan: } \\
\text { 1. Membersihkan sisa-sisa potongan } \\
\text { rambut di kursi dan lantai } \\
\text { 2. Menyilahkan pelanggan selanjutnya } \\
\text { untuk duduk di kursi cukur }\end{array}$} \\
\hline & Siap menerima pelanggan baru & \\
\hline Usana: & \multicolumn{2}{|c|}{ Jasa Cukur Rambut (kapasitas: 3 kursi cukur) } \\
\hline
\end{tabular}




\begin{tabular}{|l|l|}
\hline Tanggal: & Oktober 2016 \\
\hline Nama Posisi: & Bagian Kebersihan \\
\hline \multirow{3}{*}{ Tugas dan Tanggung } & Membuka kunci pintu dan jendela dan menyiapkan \\
Jawab: & toko buka \\
& Membersihkan ruangan cukur sebelum toko buka \\
& Membersihkan tempat cuci rambut \\
& Membersihkan ruangan cukur setelah proses cukur \\
& selesai (per pelanggan) di setiap kursi cukur \\
& Membersihkan ruangan cukur ketika toko tutup \\
\hline
\end{tabular}

Seperti contoh sebelumnya, marilah kita coba untuk menuliskan pembagian kerja untuk posisi Bagian Kebersihan dengan menggunakan format berikut:

\begin{tabular}{|l|c|}
\hline & Mengunci semua pintu dan jendela ketika toko tutup \\
\hline \multirow{3}{*}{ Keahlian: } & - Membersihkan ruangan \\
& - Kerapihan dalam bekerja \\
& - Tanggap dan cekatan \\
\hline
\end{tabular}

Diharapkan dengan 2 contoh tadi, Anda semakin jelas dan memahami bagaimana cara menuliskan pembagian kerja di unit usaha Anda.

Nah..sekarang adalah saatnya Anda menuliskan pembagian kerja yang sudah Anda susun di bagian kedua. Usahakan untuk menuliskan dengan lengkap setiap pembagian kerja yang Anda miliki.

\begin{tabular}{|l|l|}
\hline Usaha: & \\
\hline Tanggal: & \\
\hline Nama Posisi: & \\
\hline Tugas dan Tanggung Jawab: & \\
\hline Keahlian: & \\
\hline
\end{tabular}

\begin{tabular}{|l|l|}
\hline \multicolumn{1}{|c|}{ Usaha: } & \\
\hline Tanggal: & \\
\hline Nama Posisi: & \\
\hline Tugas dan Tanggung Jawab: & \\
\hline Keahlian: & \\
\hline & \\
\hline Usaha: & \\
\hline
\end{tabular}




\begin{tabular}{|l|l|}
\hline Tanggal: & \\
\hline Nama Posisi: & \\
\hline Tugas dan Tanggung Jawab: & \\
\hline Keahlian: & \\
\hline
\end{tabular}

Silakan buat daftar siapa saja orang atau orang-orang yang bisa Anda tunjukkan Alur Kerja dan Pembagian Kerja yang telah Anda tuliskan:

Daftar nama orang yang bisa saya mintakan pendapat:

Kapan saya akan mintakan pendapat mereka (rata-rata orang butuh 20-30 menit untuk membaca Alur Kerja dan Pembagian Kerja)

Setelah Anda meminta pendapat mereka, bila ada perubahan, silakan lakukan perubahan yang menurut Anda baik atau dibutuhkan.

Tuliskan kembali seluruh Alur Kerja dan Pembagian Kerja yang sudah disesuaikan dengan saran/pendapat orang-orang di atas. Beri judul: Alur Kerja dan Pembagian Kerja [Nama Produk/Jasa] dari [Nama Usaha Anda]

Jangan lupa beri tanggal kapan Anda menuliskannya Sekarang, tantangannya adalah: - Anda harus memastikan semua orang yang terlibat produksi mengetahui dan mengikuti Alur Kerja dan Pembagian Kerja tersebut.

Anda harus menginformasikan semua orang yang terlibat di unit usaha/UKM Anda bagaimana pembagian kerja tersebut agar setiap orang memahami tugas dan tanggung jawabnya masing-masing.

Selamat, Anda sudah memiliki Alur Kerja dan Pembagian Kerja untuk Produk atau Jasa Anda! Semoga dengan ini, Anda dapat mengembangkan kualitas produk/jasa UKM Anda.

Setelah mengerjakan Modul ini, Anda seharusnya sudah: o memahami apa itu Kontribusi

\section{(Pembagian Kerja)}

o sadar manfaat memiliki Pembagian Kerja

o memahami langkah-langkah umum untuk membuat alur kerja dan mampu menyusun alur kerja

o memahami bagaimana menyusun pembagian kerja dan mampu menuliskan pembagian kerja

Bila ada yang belum anda pahami mohon tandai dengan ' $x$ ' di daftar di atas. Tuliskan di kotak 126 Kemendagri - sylabus - 2018 
bawah, hal-hal yang masih Anda anggap kurang jelas atau Anda ingin ketahui lebih lanjut:

Pertanyaan- pertanyaan saya:

Lalu hubungi TIM Pendamping terdekat.

Anda siap untuk beranjak ke Modul berikutnya. 


\section{Modul I}

\section{Tanggung Jawab Tim dan Hubungan Kerja Formal}

\section{Penjelasan Umum Modul}

\section{Modul Standar Tanggung Jawab Tim dan Hubungan Kerja Formal}

\subsection{Pemahaman Umum Tanggung Jawab Tim}

\subsection{Manfaat Tanggung Jawab Tim}

\subsection{Praktik penyusunan Tanggung Jawab Tim}

\subsection{Pemahaman Umum Hubungan Kerja Formal \& Manfaatnya}

\subsection{Praktik penulisan Hubungan Kerja Formal}

Output:

o Peserta sadar pentingnya memiliki standar penulisan tanggung jawab tim dan hubungan kerja formal

o Peserta memahami apa itu tanggung jawab tim \& hubungan kerja formal

o Peserta memahami langkah-langkah umum menentukan tanggung jawab tim

o Peserta memahami langkah-langkah umum dalam menuliskan hubungan kerja formal Estimasi durasi untuk mengerjakan secara mandiri : 5-6 jam

Dukungan yang dibutuhkan :

- Pendampingan Mentor untuk penyusunan pembagian ke, setelah mencoba mengerjakan secara mandiri

o Membahas bersama UKM lain, masing-masing penyusunan tanggung jawab tim dan penulisan hubungan kerja formal 


\subsection{Pemahaman Tanggung Jawab Tim}

Sebelum kita mulai, coba Anda tuliskan di kotak bawah ini, apa yang Anda bayangkan bila mendengar kata 'Tanggung Jawab Tim"

Menurut saya, tanggung jawab tim adalah:

Penyusunan tanggung jawab tim itu biasanya dituliskan dalam bentuk struktur organisasi. Struktur organisasi adalah gambaran besar siapa yang memimpin, bagaimana tim Anda itu berkomunikasi dan juga menggambarkan siapa yang bertanggung jawab dalam pengambilan keputusan.

Bentuk gambaran tanggung jawab tim atau struktur organisasi itu biasanya digambarkan sebagai berikut:

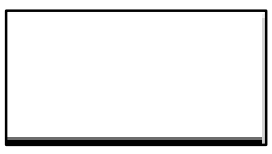

Pemilik usaha

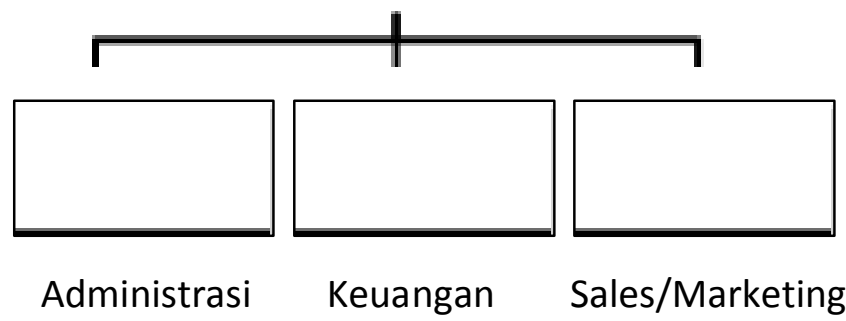

Lembar Kerja Modul

16.2. Manfaat Tanggung Jawab Tim

Dalam Modul ini, kita juga akan belajar tentang bagaimana menyusun pembagian kerja agar seluruh perangkat usaha (organisasi) bisa menjalankan tugas dan tanggung jawabnya dengan baik.

Apa manfaatnya bagi Anda, bila Anda menyusun Tanggung Jawab Tim/Struktur Organisasi? Suatu usaha (organisasi) yang memiliki penyusunan tanggung jawab tim/struktur organisasi tentunya bisa mendapatkan manfaat sebagai berikut:

- Kejelasan pekerjaan dan tanggung jawab bagi setiap orang di setiap unit usaha 
- Kejelasan dalam berkomunikasi, kepada siapa harus bertanya

- Kejelasan siapa yang harus mengambil keputusan apabila diperlukan Sehingga, jelas bahwa manfaatnya adalah sebagai dasar untuk mengatur jalannya unit usaha (organisasi) untuk mencapai hasil kerja yang efektif dan efisien.

\section{Lembar Kerja Modul}

\subsection{Praktik Penyusunan Tanggung Jawab Tim}

Agar modul ini bisa efektif membantu Anda memahami dan mencoba menyusun tanggung jawab pada unit usaha Anda, sebaiknya kita fokuskan pembahasan pada 1 produk/jasa yang Anda hasilkan.

Silakan tuliskan di bawah,apa Produk atau Jasa yang Anda akan fokuskan untuk kita bahas penetapan alur kerjanya:

Produk / Jasa yang Saya akan fokuskan untuk penetapan alur kerjanya adalah:

Baiklah, sekarang setiap kali kita membahas tentang alur kerja dan kontribusi (pembagian kerja), Anda harus fokus membayangkan tentang Produk/Jasa yang Anda tuliskan di atas ya. Langkah-langkah untuk dapat menyusun tanggung jawab tim/struktur organisasi untuk usaha adalah:

1. Menentukan alur kerja pada unit usaha (Modul

2. Menurunkan alur kerja menjadi pembagian kerja (Modul Kontribusi)

3. Menuliskan pembagian kerja dalam format standar (Modul Kontribusi)

4. Menetapkan siapa yang menjadi pengambil keputusan pada satu fungsi

5. Menggambarkan struktur organisasi sederhana

Seperti yang Anda lihat, langkah 1 dan langkah 2 sudah kita bahas pada modul sebelumnya yaitu Modul Kontribusi (Pembagian Kerja). Untuk menghemat waktu, silakan Anda lihat kembali Modul Kontribusi yang sudah Anda kerjakan untuk kita lanjutkan ke langkah 3,4,dan5. Anda tidak perlu khawatir, karena kita akan tetap menampilkan contoh langkah 1 dan langkah 2 untuk mengingatkan Anda kembali.

\section{Langkah 1 Alur Kerja}


adalah proses kerja yang dibutuhkan untuk menghasilkan suatu produk/jasa.

Penyusunan alur kerja ini dimulai dengan cara menuliskan pekerjaan apa saja yang perlu dikerjakan, meliputi:

Mari kita coba dengan contoh agar penyusunan alur kerja di atas dapat lebih mudah untuk dipahami. Misalnya saya memiliki unit usaha untuk menjual kembali (reseller) makanan dendeng balado siap saji, maka penyusunan alur kerjanya adalah sebagai berikut:

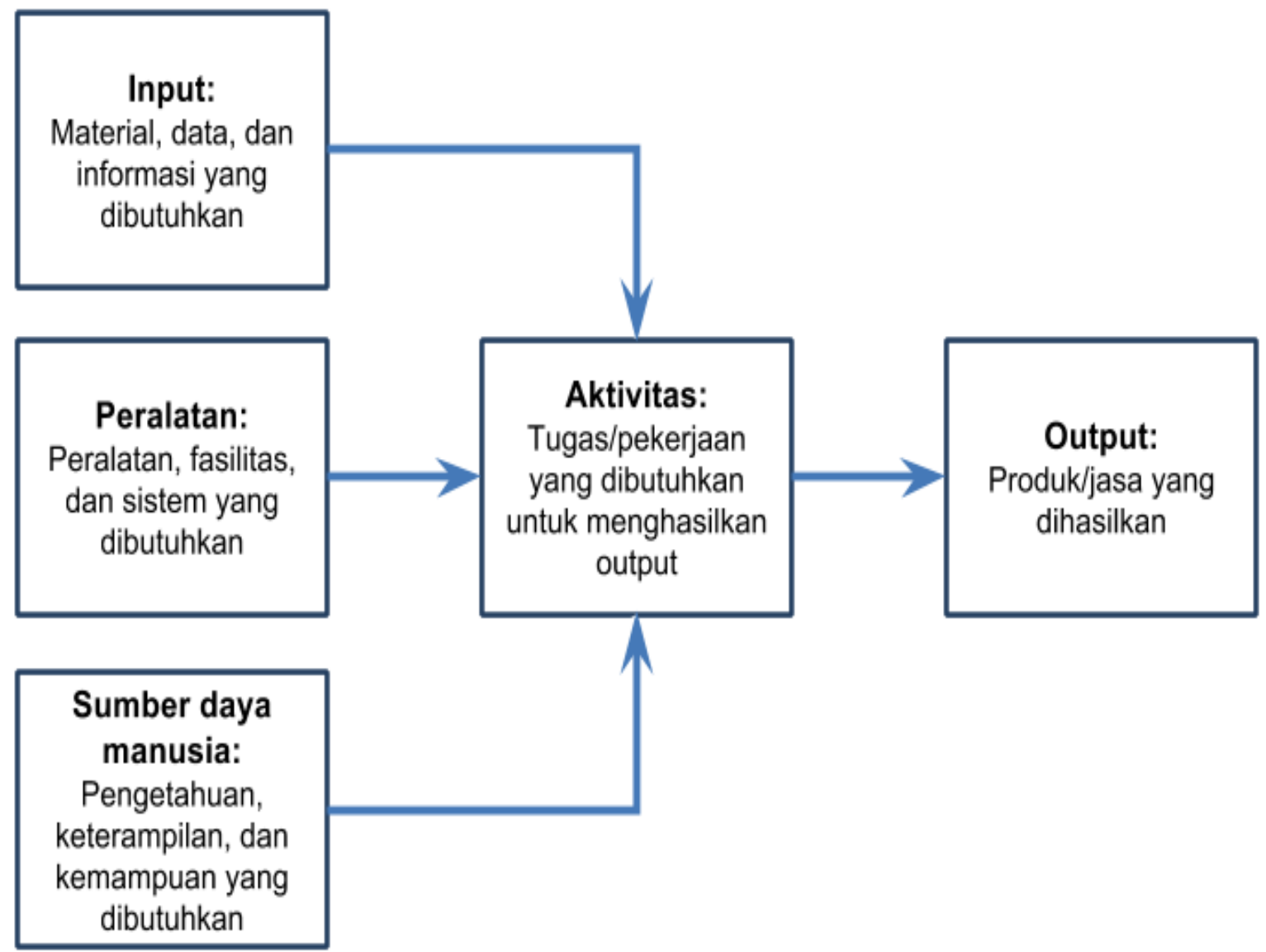

Elemen Alur Kerja Penjabaran 


\begin{tabular}{|l|l|}
\hline & $\begin{array}{l}\text { 1. Data supplier dendeng balado } \\
\text { Input }\end{array}$ \\
& $\begin{array}{l}\text { 2. Data pembeli } \\
\text { 3. Harga pasaran }\end{array}$ \\
\hline
\end{tabular}

Kita coba sekali lagi dengan contoh penyusunan alur kerja untuk usaha mencukur rambut

\begin{tabular}{|c|c|c|}
\hline Peralatan & & $\begin{array}{l}\text { 1. Sistem pemesanan } \\
\text { 2. Sistem pengepakan/pembungkusan } \\
\text { 3. Sistem pembayaran } \\
\text { 4. Sistem pengiriman } \\
\text { 5. Sistem pembukuan sederhana untuk pencatatan pembelian }\end{array}$ \\
\hline $\begin{array}{l}\text { Sumber } \\
\text { Manusia }\end{array}$ & Daya & $\begin{array}{l}\text { - Keahlian menggunakan sosial media sebagai media } \\
\text { iklan yang gratis } \\
\text { - Kemampuan menerima pesanan dari beberapa } \\
\text { media (telepon, sms, whatsapp, dll) } \\
\text { - Kemampuan pembukuan sederhana }\end{array}$ \\
\hline Aktivitas & & $\begin{array}{l}\text { 1. Menghubungi supplier/pembuat dendeng balado siap saji } \\
\text { 2. Menerima pemesanan dari pelanggan } \\
\text { 3. Merekap pesanan } \\
\text { 4. Merekap pembayaran } \\
\text { 5. Membungkus pesanan } \\
\text { 6. Mengirimkan pesanan } \\
\text { 7. Menerima masukan dari pembeli (apabila } a d a)\end{array}$ \\
\hline Output & & Jasa penjualan kembali (reseller) dendeng balado siap saji \\
\hline
\end{tabular}

(jasa).

\begin{tabular}{|l|ll|}
\hline Elemen Alur Kerja & Penjabaran \\
\hline Input & Gaya/contoh potongan rambut \\
\hline & Gunting & \\
& 16. & Pisau cukur \\
& 17. & Kursi \\
& 18. & Cermin \\
& 19. & Celemek \\
& 20. & Tissue \\
& 21. & Shampo \\
& 22. & Tempat cuci rambut \\
& 23. & Handuk \\
& 24. & Krimrambut \\
& 25. & Ruangan cukur \\
\hline
\end{tabular}




\begin{tabular}{|c|c|}
\hline Sumber Daya Manusia & $\begin{array}{l}\text { - Tukang cukur (ahli mencukur rambut) } \\
\text { - Kasir (kemampuan pembukuan sederhana) }\end{array}$ \\
\hline Aktivitas & $\begin{array}{l}\text { - Menyambut tamu } \\
\text { - Menanyakan gaya potongan rambut } \\
\text { - Menyiapkan peralatan (memasang kain penutup, } \\
\text { menyiapkan gunting, dll) } \\
\text { - Proses mencukur dilakukan } \\
\text { - Mencukur selesai } \\
\text { - Proses membersihkan sisa rambut di pelanggan } \\
\text { - Pelanggan membayar jasa } \\
\text { - Pelanggan selesai dan keluar } \\
\text { - Membersihkan bekas potongan rambut di kursi dan } \\
\text { - lantai }\end{array}$ \\
\hline Elemen Alur Kerja & Penjabaran \\
\hline Input & \\
\hline Peralatan & 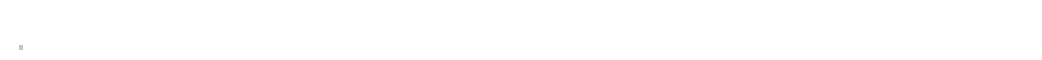 \\
\hline Sumber Daya Manusia & Jasa cukur rambut dengan kapasitas 3 kursi \\
\hline Aktivitas & \\
\hline Output & \\
\hline Output & \\
\hline
\end{tabular}

Nah, sekarang silakan Anda coba menyusun alur kerja untuk produk/jasa yang sudah Anda pilih sebelumnya. silakan diisi sedetil/selengkap mungkin yang Anda bisa. Atau Anda tinggal menyalin dari Modul Kontribusi yang sudah Anda kerjakan. 


\section{Langkah 2}

Sekarang kita akan melanjutkan langkah kedua dalam menyusun tanggung jawab tim/struktur organisasi, yaitu: menurunkan alur kerja menjadi pembagian kerja. Inti dari kegiatan ini adalah membuat pembagian kerja agar lebih jelas. Agar lebih mudah, kita bisa fokus pada aktivitas-aktivitas yang sudah Anda tuliskan pada kolom Alur Kerja.

Mari kita lihat kembali contoh berikut:

Usaha: Jasa penjualan kembali (reseller) dendeng balado siap saji

\begin{tabular}{|c|c|c|}
\hline \multirow{6}{*}{ Aktivitas } & $\begin{array}{l}\text { Menghubungi supplier/pembuat } \\
\text { dendeng balado siap saji untuk } \\
\text { menerima pesanan }\end{array}$ & \multirow{4}{*}{$\begin{array}{l}\text { Kontak dan pencatatan } \\
\text { 1. Menghubungi supplier/pembuat } \\
\text { dendeng balado siap saji untuk } \\
\text { menerima pesanan } \\
\text { 2. Menerima pesanan dari pelanggan } \\
\text { 3. Merekap pesanan } \\
\text { 4. Konfirmasi pembayaran dan } \\
\text { pembukuan }\end{array}$} \\
\hline & $\begin{array}{l}\text { Menerima pemesanan dari } \\
\text { pelanggan }\end{array}$ & \\
\hline & Merekap pesanan & \\
\hline & Merekap pembayaran & \\
\hline & Membungkus pesanan & Pengiriman \\
\hline & Mengirimkan pesanan & $\begin{array}{l}\text { 1. Membungkus pesanan } \\
\text { yang sudah dibayar oleh } \\
\text { pelanggan } \\
\text { 2. Mengirimkan pesanan } \\
\text { sesuai dengan alamat } \\
\text { pelanggan }\end{array}$ \\
\hline
\end{tabular}

\begin{tabular}{|l|l|l|}
\hline & $\begin{array}{l}\text { Menerima masukan dari pembeli } \\
\text { (apabila ada) }\end{array}$ & $\begin{array}{l}\text { Hubungan Pelanggan } \\
\text { 1. Konfirmasi pengiriman } \\
\text { 2. Menerima masukan } \\
\text { dari pembeli/pelanggan (bila ada) }\end{array}$ \\
\hline
\end{tabular}

Untuk contoh di atas, kita bisa mengelompokkan ada 3 aktivitas utama dari alur kerja tersebut. Agar lebih jelas lagi, mari kita lihat contoh selanjutnya.

\begin{tabular}{|c|c|c|}
\hline \multirow{7}{*}{ aktivitas } & Menyambut tamu & \multirow{6}{*}{$\begin{array}{l}\text { Proses cukur: } \\
\text { 1. Mempersilakan duduk di kursi cukur } \\
\text { 2. Menanyakan gaya potongan rambut } \\
\text { 3. Menyiapkan peralatan (memasang kain } \\
\text { penutup, menyiapkan gunting, dll) } \\
\text { 4. Cukur dilakukan } \\
\text { 5. Cukur selesai } \\
\text { 6. Membersihkan sisa-sisa rambut di kepala } \\
\text { dan tubuh pelanggan }\end{array}$} \\
\hline & Menanyakan gaya potongan rambut & \\
\hline & $\begin{array}{l}\text { Menyiapkan peralatan (memasang kain } \\
\text { penutup, } \\
\text { menyiapkan gunting, dll) }\end{array}$ & \\
\hline & Proses mencukur dilakukan & \\
\hline & Mencukur selesai & \\
\hline & $\begin{array}{l}\text { Proses membersihkan sisa rambut di } \\
\text { pelanggan }\end{array}$ & \\
\hline & Pelanggan membayar jasa & \\
\hline
\end{tabular}




\begin{tabular}{|l|l|l|}
\hline & $\begin{array}{l}\text { Pelanggan selesai dan keluar } \\
\text { Membersihkan bekas potongan rambut di } \\
\text { kursi dan lantai } \\
\text { Siap menerima pelanggan baru }\end{array}$ & $\begin{array}{l}\text { 1. Membersihkan sisa-sisa potongan rambut di } \\
\text { kursi dan lantai } \\
\text { 2. Menyilahkan pelanggan selanjutnya untuk } \\
\text { duduk di kursi cukur }\end{array}$ \\
\hline
\end{tabular}

Usaha: Jasa Cukur Rambut (kapasitas: 3 kursi cukur)

Pada contoh di atas, terdapat 3 pembagian kerja utama. Sekarang tugas Anda adalah untuk menurunkan aktivitas pada alur kerja yang sudah Anda buat sebelumnya menjadi pembagian kerja seperti pada contoh pada halaman selanjutnya.

Tuliskan pembagian kerja yang Anda buat pada lembar berikut. Atau Anda dapat menyalin

\begin{tabular}{|c|c|c|}
\hline \multirow{7}{*}{ Aktivitas } & $\begin{array}{l}\text { Menghubungi supplier/pembuat } \\
\text { dendeng balado siap saji untuk } \\
\text { menerima pesanan }\end{array}$ & \multirow{7}{*}{$\begin{array}{l}\text { Kontak dan pencatatan } \\
\text { 1. Menghubungi supplier / pembuat dendeng } \\
\text { balado siap saji untuk menerima pesanan } \\
\text { 2. Menerima pesanan dari pelanggan } \\
\text { 3. Merekap pesanan } \\
\text { 4. Konfirmasi pembayaran dan pembukuan } \\
\text { Pengiriman } \\
\text { 1. Membungkus pesanan yang sudah dibayar oleh } \\
\text { pelanggan } \\
\text { 2. Mengirimkan pesanan sesuai dengan alamat } \\
\text { pelanggan } \\
\text { Hubungan Pelanggan } \\
\text { 1. Konfirmasi pengiriman } \\
\text { 2. Menerima masukan dari pembeli/pelanggan (bila } \\
\text { ada) }\end{array}$} \\
\hline & Menerima pemesanan dari pelanggan & \\
\hline & Merekap pesanan & \\
\hline & Merekap pembayaran & \\
\hline & Membungkus pesanan & \\
\hline & Mengirimkan pesanan & \\
\hline & $\begin{array}{l}\text { Menerima masukan dari pembeli } \\
\text { (apabila ada) }\end{array}$ & \\
\hline
\end{tabular}

dari Modul Kontribusi yang sudah Anda kerjakan sebelumnya.

Usaha:

\begin{tabular}{|l|l|l|}
\hline Aktivitas & & \\
\hline
\end{tabular}

\section{Langkah 3}

Bila masih ada yang ingin Anda diskusikan, silakan hubungi Pendamping Anda. Kita akan membahas langkah ketiga agar pembagian kerja (kontribusi) usaha Anda dapat segera diselesaikan. Langkah tersebut adalah menuliskan pembagian kerja di dalam format standar. Anda tidak perlu khawatir, karena kita akan membuat format penulisan pembagian kerja tersebut dalam bentuk sesederhana mungkin. Dokumen ini pada nantinya akan sangat 
membantu Anda apabila usaha Anda semakin besar dan membutuhkan pengembangan. Anda bisa mengikuti format penulisan berikut ini atau mengikuti format lainnya yang Anda rasa lebih nyaman. Dalam menuliskan pembagian kerja ini, kita perlu melihat lagi tabel pembagian kerja yang sudah kita susun.

Sebagai contoh pada usaha Jasa penjualan kembali (reseller) dendeng balado siap saji, kita akan berlatih untuk menuliskan pembagian kerja untuk Kontak dan Pencatatan. Format penulisan bisa Anda lihat pada halaman selanjutnya.

\begin{tabular}{|l|l|}
\hline Usaha: & Jasa penjualan kembali (reseller) dendeng balado siap saji \\
\hline Tanggal: & Oktober 2016 \\
\hline Nama Posisi: & Kontak dan Pencatatan \\
\hline Tugas dan Tanggung Jawab: & $\begin{array}{l}\text { 1. Menghubungi supplier/pembuat dendeng balado siap saji untuk } \\
\text { menerima pesanan } \\
\text { 2. Menerima pesanan dari pelanggan } \\
\text { 4. Menfirmasi pembayaran }\end{array}$ \\
& $\begin{array}{l}\text { 5. Melakukan rekapitulasi pembukuan sederhana setiap minggu } \\
\text { 6. Melakukan pembayaran kepada supplier sesuai waktu yang }\end{array}$ \\
\hline \multirow{5}{*}{ Keahlian: } & $\begin{array}{l}\text { 1. Melakukan pencatatan dengan rapi } \\
\text { 2. Melakukan pembukuan sederhana } \\
\text { 3. Melayani pelanggan } \\
\text { 4. Membina hubungan baik dengan supplier dan pelanggan }\end{array}$ \\
\hline
\end{tabular}

Nah, sudah jelas kan? Kita coba sekali lagi dengan contoh kedua.

\begin{tabular}{|c|c|c|}
\hline \multirow{7}{*}{ aktivitas } & Menyambut tamu & \multirow{6}{*}{$\begin{array}{l}\text { Proses cukur: } \\
\text { 1. Mempersilakan duduk di kursi cukur } \\
\text { 2. Menanyakan gaya potongan rambut } \\
\text { 3.Menyiapkan peralatan (memasang kain } \\
\text { penutup, menyiapkan gunting, dll) } \\
\text { 4. Cukur dilakukan } \\
\text { 5. Cukur selesai } \\
\text { 6. Membersihkan sisa-sisa rambut di kepala } \\
\text { dan tubuh pelanggan }\end{array}$} \\
\hline & $\begin{array}{lll}\begin{array}{l}\text { Menanyakan gaya potongan } \\
\text { rambut }\end{array} & \\
\end{array}$ & \\
\hline & $\begin{array}{l}\text { Menyiapkan peralatan (memasang } \\
\text { kain penutup, menyiapkan gunting, } \\
\text { dll) }\end{array}$ & \\
\hline & Proses mencukur dilakukan & \\
\hline & Mencukur selesai & \\
\hline & $\begin{array}{l}\text { Proses membersihkan sisa rambut } \\
\text { di pelanggan }\end{array}$ & \\
\hline & Pelanggan membayar jasa & Kasir: \\
\hline
\end{tabular}




\begin{tabular}{|l|l|l|}
\hline & & $\begin{array}{l}\text { 1. Menyiapkan tanda bukti pembayaran } \\
\text { 2. Menerima pembayaran }\end{array}$ \\
\cline { 2 - 3 } & Pelanggan selesai dan keluar & $\begin{array}{l}\text { 3. Merekap pembayaran ke pembukuan } \\
\text { 4. Mengucapkan terima kasih }\end{array}$ \\
\cline { 2 - 3 } & Membersihkan bekas potongan & Bagian kebersihan: \\
rambut di kursi dan lantai & 1. Membersihkan sisa-sisa potongan rambut di \\
\cline { 2 - 3 } & kursi dan lantai \\
Siap menerima pelanggan baru & $\begin{array}{l}\text { 2. Menyilahkan pelanggan selanjutnya untuk } \\
\text { duduk di kursi cukur }\end{array}$ \\
\hline
\end{tabular}

Seperti contoh sebelumnya, marilah kita coba untuk menuliskan pembagian kerja untuk posisi Bagian Kebersihan dengan menggunakan format berikut:

\begin{tabular}{|l|l|}
\hline Usaha: & Jasa Cukur Rambut (kapasitas: 3 kursi cukur) \\
\hline Tanggal: & Oktober 2016 \\
\hline Nama & Bagian Kebersihan \\
\hline Keahlian: & $\begin{array}{l}\text { 1. Membersihkan ruangan } \\
\text { 2. Kerapihan dalam bekerja }\end{array}$ \\
\hline
\end{tabular}

Diharapkan dengan 2 contoh tadi, Anda semakin jelas dan memahami bagaimana cara menuliskan pembagian kerja di unit usaha Anda.

Nah..sekarang adalah saatnya Anda menuliskan pembagian kerja yang sudah Anda susun. Usahakan untuk menuliskan dengan lengkap setiap pembagian kerja yang Anda miliki. Atau Anda tinggal menyalin dari Modul Kontribusi yang sudah Anda pernah lakukan sebelumnya. Langkah 1.

\begin{tabular}{|l|l|}
\hline Usaha: & \\
\hline Tanggal: & \\
\hline Nama Posisi: & \\
\hline Tugas dan Tanggung Jawab: & \\
\hline Keahlian: & \\
\hline
\end{tabular}


Langkah 2.

\begin{tabular}{|l|l|}
\hline Usaha: & \\
\hline Tanggal: & \\
\hline Nama Posisi: & \\
\hline Tugas dan Tanggung Jawab: & \\
\hline Keahlian: & \\
\hline
\end{tabular}

Langkah 3.

\begin{tabular}{|l|l|}
\hline Usaha: & \\
\hline Tanggal: & \\
\hline Nama Posisi: & \\
\hline Tugas dan Tanggung Jawab: & \\
\hline Keahlian: & \\
\hline
\end{tabular}

\section{Langkah 4}

Langkah selanjutnya adalah menetapkan siapa yang menjadi pengambilan keputusan pada unit kerja/usaha Anda. Posisi pengambil keputusan ini biasanya ada atau melekat di posisi pemimpin unit kerja/usaha tersebut.

Pengambilan keputusan ini diperlukan apabila ada masalah atau kendala yang dihadapi ketika proses produksi barang/jasa. Sehingga masalah tersebut bisa diatasi dan proses kerja bisa dilanjutkan sampai selesai.

Penentuan siapa yang berhak menjadi pengambil keputusan ini biasanya ditentukan oleh pemilik usaha. Karena pemilik usaha memiliki kepercayaan kepada orang tersebut untuk dapat menjalankan usaha/UKM. Tidak menutup kemungkinan bahwa pemilik usaha adalah pimpinan tertinggi yang memiliki hak untuk mengambil keputusan.

Agar lebih jelas, marilah kita lihat dari contoh berikut ini. Harap diingat contoh ini tidak mutlak, karena bergantung pada situasi dan kondisi unit usaha/UKM. 
Contoh 1. Usaha: Reseller dendeng balado siap saji

\begin{tabular}{|c|c|c|}
\hline Aktivitas & Pembagian Kerja & Pengambil Keputusan \\
\hline $\begin{array}{l}\text { Menghubungi supplier/pembuat dendeng } \\
\text { balado siap saji untuk menerima pesanan }\end{array}$ & \multirow{4}{*}{$\begin{array}{l}\text { Kontak dan pencatatan } \\
\text { 1.Menghubungi supplier/pembuat } \\
\text { dendeng balado siap saji untuk } \\
\text { menerima pesanan } \\
\text { 2.Menerima pesanan dari pelanggan } \\
\text { 3.Merekap pesanan } \\
\text { 4.Konfirmasi pembayaran dan } \\
\text { pembukuan }\end{array}$} & \\
\hline Menerima pemesanan dari pelanggan & & \\
\hline Merekap pesanan & & 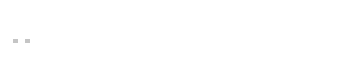 \\
\hline Merekap pembayaran & & $=$ \\
\hline Membungkus pesanan & \multirow{2}{*}{$\begin{array}{l}\text { Pengiriman } \\
\text { 1. Membungkus pesanan yang sudah } \\
\text { dibayar oleh pelanggan } \\
\text { 2. Mengirimkan pesanan sesuai dengan } \\
\text { alamat pelanggan }\end{array}$} & \\
\hline Mengirimkan pesanan & & \\
\hline $\begin{array}{l}\text { Menerima masukan dari pembeli (apabila } \\
\text { ada) }\end{array}$ & $\begin{array}{l}\text { Hubungan Pelanggan } \\
\text { 1.Konfirmasi pengiriman } \\
\text { 2.Menerima masukan } \\
\text { pembeli/pelanggan (bila ada) }\end{array}$ & \\
\hline
\end{tabular}

Situasi:

1. UKM ini masih tergolong baru dengan skala usaha kecil.

2. UKM ini adalah milik 2 orang bersaudara yang memulai usaha ini.

3. Saat ini bisnis reseller ini hanya dijalankan oleh mereka berdua.

4. Sehingga, salah satu pemilik usaha yang merangkap sebagai posisi Kontak dan Pencatatan menjadi posisi pengambil keputusan (kotak putih)

Contoh 2. Usaha: Jasa Cukur Rambut (kapasitas 3 kursi)

\begin{tabular}{|c|c|c|}
\hline Aktivitas & Pembagian Kerja & $\begin{array}{l}\text { Pengambil } \\
\text { Keputusan }\end{array}$ \\
\hline Menyambut tamu & \multirow{5}{*}{$\begin{array}{l}\text { Proses cukur: } \\
\text { 1.Mempersilakan duduk di kursi cukur } \\
\text { 2.Menanyakan gaya potongan rambut } \\
\text { 3.Menyiapkan peralatan ( memasang } \\
\text { kain penutup, menyiapkan gunting, } \\
\text { dll) } \\
\text { 4. Cukur dilakukan } \\
\text { 5. Cukur selesai } \\
\text { 6.Membersihkan sisa - sisa rambut di } \\
\text { kepala dan tubuh pelanggan }\end{array}$} & \\
\hline Menanyakan gaya potongan rambut & & \\
\hline $\begin{array}{l}\text { Menyiapkan peralatan (memasang } \\
\text { kain penutup, menyiapkan gunting, } \\
\text { dll) }\end{array}$ & & \\
\hline Proses mencukur dilakukan & & \\
\hline Mencukur selesai & & \\
\hline
\end{tabular}


Proses membersihkan sisa rambut di pelanggan

Pelanggan membayar jasa

Kasir:

1. Menyiapkan tanda bukti pembayaran

2. Menerima pembayaran

3. Merekap pembayaran ke pembukuan

4. Mengucapkan terima kasih

Pelanggan selesai dan keluar

Membersihkan bekas potongan rambut di kursi dan lantai

Bagian kebersihan:

1. Membersihkan sisa-sisa potongan rambut di kursi dan lantai

2. Menyilahkan pelanggan selanjutnya untuk duduk di kursi cukur

Siap menerima pelanggan baru

Situasi:

1. Dengan kapasitas 3 kursi cukur, UKM ini memiliki 3 tukang cukur, 1 kasir dan 1 bagian kebersihan.

2. Pengambilan keputusan ini dapat didelegasikan pemilik usaha kepada posisi Tukang Cukur Senior atau bisa juga posisi Kasir. Karena masalah yang muncul kemungkinan terkait masalah proses pencukuran (misalnya antrian panjang sehingga sudah memasuki jam tutup toko) atau masalah pembayaran (misalnya uangnya kurang atau dompet ketinggalan)

Nah, sekarang saatnya Anda belajar menentukan siapakah yang menduduki posisi pengambil keputusan di unit usaha Anda.

Apabila Anda adalah pemilik usaha dan merasa Anda adalah orang yang memiliki kuasa untuk mengambil keputusan itu diperbolehkan. Karena penting untuk Anda ketahui, penentuan posisi pengambilan keputusan ini merupakan kewenangan Anda sepenuhnya kepada siapa Anda delegasikan.

Untuk membantu Anda, silakan Anda uraikan bagaimana situasi unit usaha/UKM Anda. Hal ini akan mempermudah Anda untuk menentukan posisi pengambil keputusan. 


\begin{tabular}{|c|c|c|}
\hline Aktivitas & Pembagian Kerja & Pengambil Keputusan \\
\hline & & \\
\hline & & \\
\hline & & \\
\hline & & \\
\hline & & \\
\hline & & \\
\hline & & \\
\hline
\end{tabular}

Situasi:

\section{Langkah 5}

Akhirnya kita memasuki langkah kelima dalam penyusunan tanggung jawab tim/struktur organisasi. Bagian yang juga tidak kalah penting adalah menggambarkan tanggung jawab tim/struktur organisasi tersebut. Masih ingat bagaimana gambaran struktur organisasi yang sudah dicontohkan pada bagian awal modul ini? Cukup mudah bukan?

Mari kita gunakan Contoh 1. dan Contoh 2. untuk memudahkan Anda memahami bagaimana menggambarkan struktur organisasi Anda.

Contoh 1. Usaha: Reseller dendeng balado siap saji

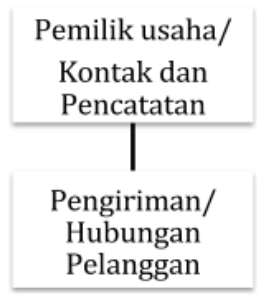

Contoh 2. Usaha: Jasa Cukur Rambut (kapasitas 3 kursi)

Cara mudah untuk menggambarkan tanggung jawab tim/struktur organisasi adalah:

1. Tentukan pembagian kerja dan pengambil keputusan.

2. Siapkan kotak-kotak kosong untuk Anda isi dengan posisi-posisi sesuai dengan pembagian kerja yang sudah ditentukan. 
3. Tuliskan "Pemilik Usaha" pada kotak yang paling atas. Kotak yang paling atas ini biasanya hanya ada 1 kotak saja yang berarti pimpinan tertinggi. Tetapi tidak menutup kemungkinan apabila unit usaha Anda terdapat 2 pemilik usaha yang memiliki kuasa yang sama.

4. Tuliskan posisi pada kotak di baris kedua di bawah kotak "Pemilik Usaha". Kotak di baris kedua ini menunjukkan posisi-posisi yang melapor langsung kepada "Pemilik Usaha".

5. Tuliskan nama orangnya di bawah tulisan nama posisinya untuk menunjukkan siapa pemegang jabatan tersebut.

6. Anda juga bisa meletakkan foto di samping setiap nama.

7. Demikian seterusnya

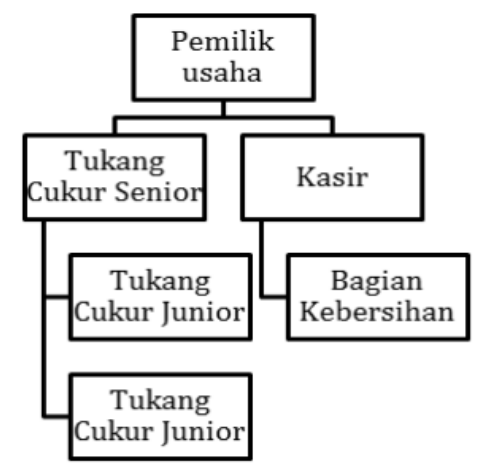

Apabila unit usaha Anda sudah memiliki SDM/Anggota tim lebih dari 10 orang, maka posisi "pengambil keputusan" biasanya diletakkan di posisi atas. Anda bisa lihat pada contoh 2. bahwa posisi "Tukang Cukur Senior" terletak di atas posisi "Tukang Cukur Junior" . Hal ini menunjukkan bahwa posisi "Tukang Cukur Senior" memiliki kuasa pengambil keputusan dan melapor langsung kepada posisi "Pemilik Usaha"

Sekarang saatnya Anda berlatih untuk menggambarkan tanggung jawab tim/struktur organisasi yang Anda miliki pada halaman selanjutnya. Anda dapat menambahkan kotakkotak sesuai dengan kebutuhan Anda.

Selamat! Ini langkah awal Anda untuk bisa menyusun tanggung jawab tim/struktur organisasi di unit usaha Anda.. 
Setelah mengerjakan Modul ini, Anda seharusnya sudah:

o memahami apa itu tanggung jawab tim

o sadar manfaat memiliki tanggung jawab tim

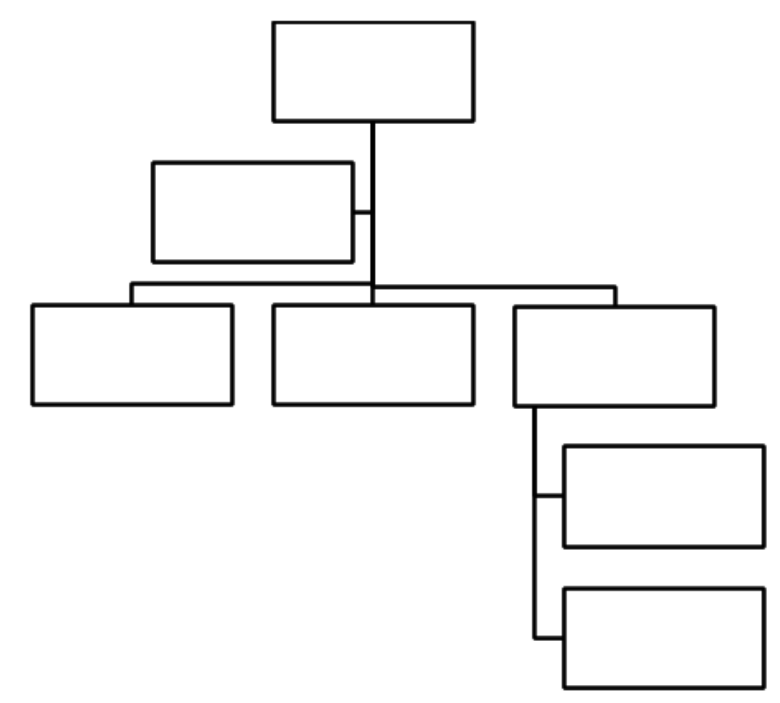

o memahami langkah-langkah umum untuk membuat tanggung jawab tim, dan

o mampu menggambar tanggung jawab tim/struktur organisasi

Bila ada yang belum anda pahami, mohon tandai dengan ' $x$ ' di daftar di atas. Tuliskan di kotak bawah, hal-hal yang masih Anda anggap kurang jelas atau Anda ingin ketahui lebih lanjut:

Pertanyaan- pertanyaan saya:

Lalu hubungi TIM Pendamping terdekat. 


\section{Lembar Kerja Modul}

\section{Pemahaman Umum}

\section{Hubungan Kerja Formal \& Manfaatnya}

Sebelum kita mulai, coba Anda tuliskan di kotak bawah ini, apa yang Anda bayangkan bila mendengar kata "Hubungan Kerja Formal" dan apa manfaatnya memiliki Hubungan Kerja Formal

\begin{tabular}{|l|l|}
\hline $\begin{array}{l}\text { Menurut saya, Kontribusi (pembagian kerja) } \\
\text { adalah: }\end{array}$ \\
\hline $\begin{array}{l}\text { Manfaat memiliki hubungan kerja formal } \\
\text { adalah: }\end{array}$ & \\
\hline
\end{tabular}

Setelah menulis jawaban Anda, silakan lanjut ke halaman berikutnya. Hubungan Kerja Formal yang lebih dikenal dengan sebutan "Perjanjian Kerja" adalah perjanjian antara pekerja dengan pengusaha atau pemberi kerja yang memuat syarat-syarat kerja, hak, dan kewajiban para pihak (UU No.13 Tahun 2003 Tentang Ketenagakerjaan).

Sebagai pemilik usaha (pengusaha), Anda perlu untuk mengetahui dan memahami UU No.13 Tahun 2003 Tentang Ketenagakerjaan ini sebagai aturan dasar yang harus dipatuhi. Seluruh aturan mengenai ketenagakerjaan di atur di undang-undang ini termasuk diantaranya adalah Hubungan Kerja Formal/Perjanjian Kerja.

UU No.13 Tahun 2003 dapat dengan mudah Anda dapatkan dalam bentuk buku, hardcopy, maupun softcopy.

Apa manfaatnya kita perlu memiliki hubungan kerja formal?

1. Melindungi pengusaha dan pekerja apabila terjadi masalah.

2. Kejelasan status pekerja

3. Kejelasan hak dan kewajiban masing-masing pihak Menurut pasal 54 UU No.13/2003, Perjanjian kerja yang dibuat secara tertulis sekurang kurangnya harus memuat:

a. nama, alamat perusahaan, dan jenis usaha

b. nama, jenis kelamin, umur, dan alamat pekerja/buruh

c. jabatan atau jenis pekerjaan 
d. tempat pekerjaan

e. besarnya upah dan cara pembayarannya

f. syarat syarat kerja yang memuat hak dan kewajiban pengusaha dan pekerja/buruh

g. mulai dan jangka waktu berlakunya perjanjian kerja

h. tempat dan tanggal perjanjian kerja dibuat; dani. tanda tangan para pihak dalam perjanjian kerja 


\section{Lembar Kerja Modul}

\subsection{Praktik Penulisan Hubungan Kerja Formal}

Berdasarkan penjelasan di atas, sekarang saatnya Anda mencoba menuliskan Hubungan Kerja Formal/Perjanjian Kerja yang sesuai dengan UU No.13/2003. Anda dapat menggunakan contoh berikut sebagai dasar tulisan Anda. Jangan lupa, Anda bisa menambahkan hal-hal yang Anda anggap perlu di dalam Perjanjian Kerja Anda. Silakan gunakan kertas tambahan dan jangan lupa memasukkan kertas tambahan tersebut ke dalam modul ini.

KOP-PERUSAHAAN

SURAT PERJANJIAN KERJA CV. CUKUR GANTENG Nomor: SPK/

Yang bertanda tangan di bawah ini:

1. Nama :

2. Jabatan :

3. Alamat :

Dalam hal ini bertindak atas nama direksi (____ yang berkedudukan di ) dan selanjutnya disebut PIHAK PERTAMA.

4. Nama :

5. Tempat dan tanggal lahir :

6. Pendidikan terakhir :

7. Jenis kelamin :

8. Agama :

9. Alamat :

10 No. KTP/SIM :

11. Telepon :

Dalam hal ini bertindak untuk dan atas nama diri pribadi dan selanjutnya disebut PIHAK KEDUA.

Pasal 1 Mulai Bekerja

Para Pihak setuju dan sepakat bahwa Karyawan mulai bekerja pada tanggal (_). 
Pasal 2 Posisi dan Tugas

PERUSAHAAN dengan ini menunjuk Karyawan dan Karyawan menerima penunjukkan kerja sebagai ). Karyawan menyatakan kesediaan dan berkewajiban untuk melakukan aktivitas sebagaimana jabatan yang telah ditentukan tersebut.

Pasal 3 Gaji dan Tunjangan

1. Karyawan menerima gaji pokok adalah sebesar (Rp. ) perbulan.

2. Gaji karyawan dibayarkan selambatnya pada hari kerja terakhir pada bulan yang bersangkutan.

Pasal 4 Berakhirnya Perjanjian Kerja

1. Para pihak dapat memutuskan Perjanjian ini sewaktu-waktu dengan memberikan pemberitahuan tertulis terlebih dahulu dalam jangka waktu 30 (tiga puluh) hari sebelum hari pengunduran dirinya.

2. Pemutusan Hubungan Kerja (PHK) yang dikarenakan pelanggaran yang dilakukan PIHAK KEDUA atau karena hal-hal yang merugikan PIHAK PERTAMA, maka PIHAK PERTAMA tidak wajib memberikan pesangon.

Pasal 5 Lain-lain

Ketentuan lainnya yang belum ditentukan dalam Perjanjian Kerja ini mengacu kepada Peraturan Perusahaan.

Pasal 6 Penutup

Demikianlah perjanjian ini dibuat, disetujui, dan ditandatangani oleh Para Pihak, dibuat dalam rangkap dua, masing-masing mempunyai kekuatan hukum yang sama. Satu dipegang oleh PIHAK KEDUA dan lainnya untuk PIHAK PERTAMA.

Jakarta,

KARYAWAN DIREKSI

Silakan buat daftar siapa saja orang atau orang-orang yang bisa Anda tunjukkan Tanggung Jawab Tim/Struktur Organisasi dan Hubungan Kerja Formal yang telah Anda tuliskan:

Daftar nama orang yang bisa saya mintakan pendapat:

Kapan saya akan mintakan pendapat mereka (rata-rata orang butuh 30 - 45 menit untuk membaca Tanggung Jawab Tim/Struktur Organisasi dan Hubungan Kerja Formal) 
Setelah Anda meminta pendapat mereka, bila ada perubahan, silakan lakukan perubahan yang menurut Anda baik atau dibutuhkan.

Tuliskan kembali seluruhTanggung Jawab Tim/Struktur Organisasi dan Hubungan Kerja Formal yang sudah disesuaikan dengan saran/pendapat orang-orang di atas. Beri judul: Tanggung Jawab Tim/Struktur Organisasi dan Hubungan Kerja Formal [Nama Produk/Jasa] dari [Nama Usaha Anda]

Jangan lupa beri tanggal kapan Anda menuliskannya Sekarang, tantangannya adalah:

1. Anda harus memastikan semua orang yang terlibat produksi mengetahui Tanggung Jawab Tim/Struktur Organisasi dan Hubungan Kerja Formal tersebut.

2. Anda harus menginformasikan semua orang yang terlibat di unit usaha/UKM Anda dan memastikan bahwa setiap orang memiliki Tanggung Jawab Tim/Struktur Organisasi dan Hubungan Kerja Formal masing-masing. Selamat, Anda sudah memiliki Tanggung Jawab Tim/Struktur Organisasi dan Hubungan Kerja Formal untuk Produk atau Jasa Anda! Semoga dengan ini, Anda dapat mengembangkan kualitas produk/jasa UKM Anda. Setelah mengerjakan Modul ini, Anda seharusnya sudah:

o menyadari pentingnya memiliki standar penulisan tanggung jawab tim dan hubungan kerja formal

o memahami apa itu tanggung jawab tim \& hubungan kerja formal

o memahami langkah-langkah umum menentukan tanggung jawab tim

o memahami langkah-langkah umum dalam menuliskan hubungan kerja formal

Bila ada yang belum anda pahami mohon tandai dengan ' $x$ ' di daftar di atas. Tuliskan di kotak bawah, hal-hal

yang masih Anda anggap kurang jelas atau Anda ingin ketahui lebih lanjut:

Pertanyaan-pertanyaan saya:

Lalu hubungi tim Pendamping terdekat.

Anda siap untuk beranjak ke Modul berikutnya. 
MODUL I

\section{Membuat Brand yang Kuat.}

Contoh kasus : Saat kita membeli air minum biasa di sebuah warung makan mungkin dengan harga Rp 1000 - Rp 5000 cukup untuk mendapatkan segelas air putih. Namun bila kita membeli air putih yang sama dalam kemasan dan telah diberikan label merek, maka harganya bisa menjadi $2 x$ lipat bahkan lebih.

Itulah kekuatan dari Branding. Jadi, apakah Branding itu?

Branding adalah suatu kegiatan untuk membuat nama, simbol atau pun identitas untuk membedakan satu produk/jasa dengan produk/jasa yang lainnya. Jika Anda adalah seorang pengusaha yang baru ingin memulai sebuah bisnis, mungkin Anda masih belum merasa butuh untuk membuat brand karena Anda sudah cukup percaya diri dengan produk yang sudah dibuat. Namun sayangnya, produk/jasa yang Anda buat tidak dapat otomatis terjual dengan sendirinya. Anda harus membentuk sebuah brand untuk produk/jasa yang Anda buat untuk berbagai manfaat sebagai berikut:

\section{Memberikan Identitas Produk/Jasa Anda}

Sama seperti apa yang sudah disampaikan pada beberapa paragraf sebelumnya; brand berfugsi sebagai identitas. Identitas itu lah yang membedakan produk/jasa Anda dengan produk/jasa sejenis milik kompetitor. Identitas brand yang paling dasar adalah design logo.

\section{Menyampaikan Nilai Produk/Jasa Anda}

Apakah artinya Nilai disini? Nilai adalah keunggulan produk / jasa anda. Pada saat Anda membangun sebuah brand, berarti Anda sudah siap untuk menyampaikan pesan berupa nilai yang terkandung pada produk/jasa yang Anda produksi kepada masyarakat. Nilai yang Anda anut dan sampaikan tersebut bisa menjadi daya tarik tersendiri bagi target market dari produk/jasa yang brand Anda tawarkan.

\section{Menjalin Komunikasi dengan Pelanggan dan Target Market}

Dengan adanya brand, berarti Anda telah membuka pintu komunikasi dengan target market atau calon pelanggan Anda. ; nilai, kelebihan dari produk/jasa, unique selling point (USP) produk/jasa dan berbagai hal lainnya. Selain itu, kehadiran brand juga memungkinkan Anda untuk mendapatkan review dari pelanggan yang telah mencoba produk/jasa dari brand Anda. 


\section{Membangun Kredibilitas dan Persepsi}

Setelah beberapa orang mencoba produk/jasa dari brand yang Anda buat, mereka akan mengetahui kredibilitas brand Anda dan mulai memiliki pandangan pada brand anda. Panduan Dasar Membuat sebuah Brand.

Ada beberapa langkah dasar untuk membuat produk atau jasa anda menjadi sebuah brand yang baik, yaitu :

\section{A. Menentukan Profil Usaha.}

1. "Mengapa kita membuat bisnis ini?"

2. Kepada siapa kita menjual produk / jasa kita?

3. Jenis Kelamin :

4. Usia :

5. Pekerjaan:

6. Penghasilan:

7. Wilayah geografis:

Siapa sajakah yang sudah menjalankan bisnis ini?

(Tujuannya adalah mengenal kompetitor dan menjadi brand yang lebih baik dari kompetitor). Apa saja keunggulan kompetitor anda?

Seperti apakah keunggulan produk atau jasa kita sekarang yang dapat melebihi keunggulan kompetitor di atas?

Sebutkan keunggulan anda dan hindari keunggulan harga lebih murah sebagai keunggulan anda.

\section{B. Menentukan Identitas Produk dan Jasa Anda.}

1. Menentukan nama produk / jasa Nama bisnis kita adalah hal pertama dimana kita berkomunikasi dengan pelanggan kita. Dan ini menjadi sangat penting karena akan menentukan kesan pertama bisnis kita kepada calon pelanggan. 
Berikut adalah tips menentukan nama bagi produk / jasa anda:

1. Pilih nama yang tidak hanya menarik untuk kita sebagai pemilik namun juga menarik dan bisa dipahami oleh calon pelanggan.

2. Jangan memilih nama terlalu panjang, membingungkan, atau sulit untuk dilafalkan. Usahakan terdiri dari 2-3 suku kata saja, dan maksimal 4 suku kata.

3. Usahakan memiliki nama yang bisa didaftarkan pada Dirjen HAKI.

4. Menentukan Logo Perusahaan Logo adalah ciri khas atau wakil suatu brand.

Latihan : Tunjukan gambar-gambar logo perusahaan brand lokal / nasional tanpa menunjukan namanya, dan sebutkan mewakili brand apakah logo tersebut?

Contoh:

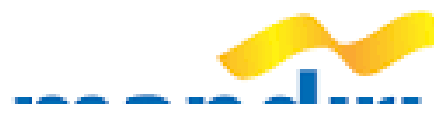

Brand apakah yang diwakili oleh logo diatas?

Menarik bukan?

Bagaimana sebuah logo dapat dikenal bahkan tanpa brand tersebut ditulis.

\section{Berikut adalah tips membuat logo:}

1. Unik dan kreatif Logo harus terlihat unik dan kreatif agar konsumen dapat membedakan suatu brand dari kompetitornya.

2. Sederhana tapi memiliki makna Buatlah logo yang sederhana, mudah dan nyaman dilihat, dan memiliki makna atau cerita dari logo tersebut.

3. Warna adalah kunci yang penting. Berikut adalah panduan warna dan arti dari warnawarna utama yang dapat kita digunakan sebagai panduan karakter brand kita yang ingin kita sampaikan ke calon pelanggan: 

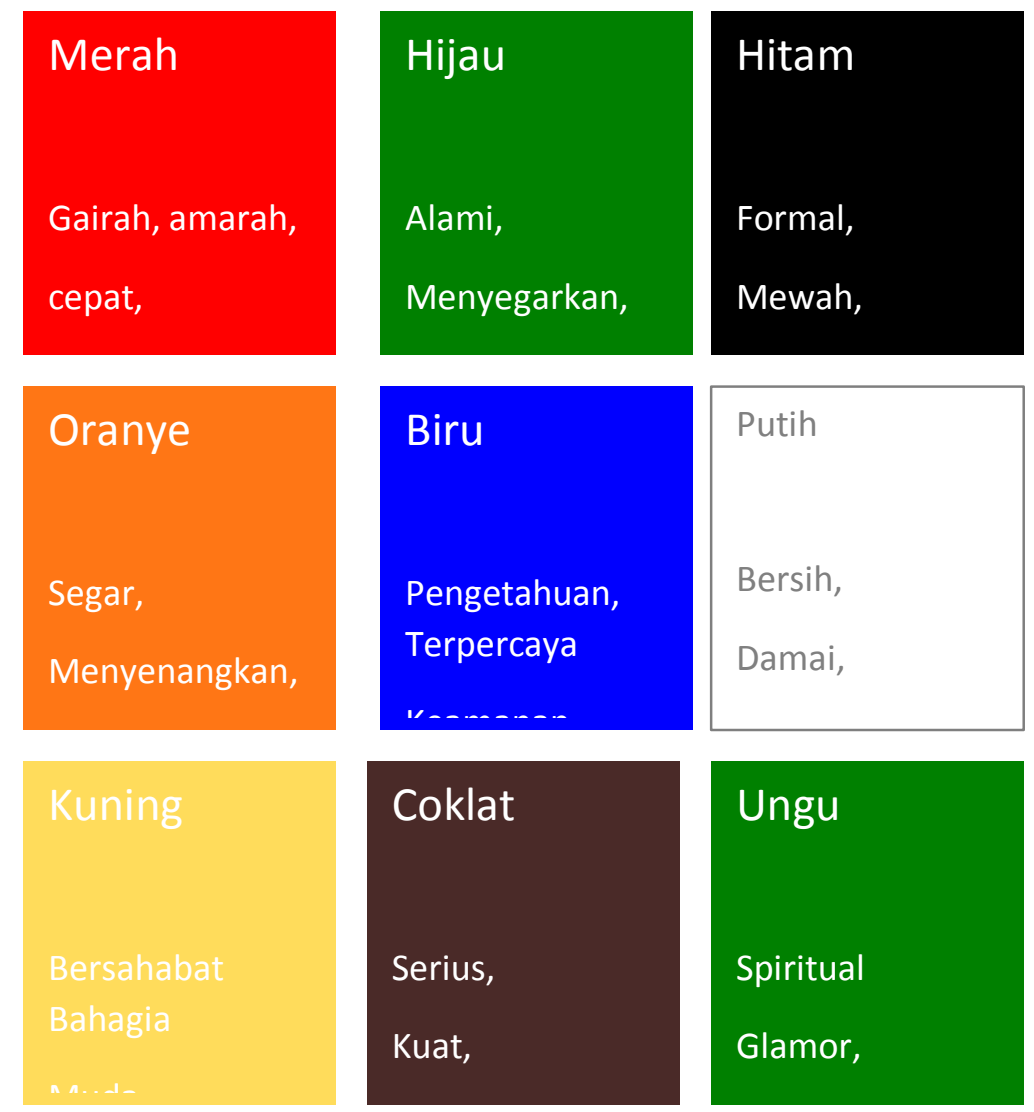

\section{Menentukan Segmentasi Pelanggan Sederhana}

Hal terpenting yang perlu dilakukan saat menentukan target pelanggan adalah membuat segmentasi pelanggan. Dalam pengertian sederhana, segmentasi pelanggan dapat diartikan sebagai pengelompokkan tertentu pelanggan potensial Anda berdasarkan kemiripan tertentu. Cara praktis menentukan target pelanggan adalah dengan memilih segmentasi pelanggan yang tepat. Berikut ini adalah langkah praktis yang bisa Anda lakukan untuk menentukan target pelanggan:

1. Pilih Lokasi yang Menjadi Target menjual produk / jasa Anda Pertama adalah tentang geografis. Tentukanlah lokasi mana saja yang dijangkau oleh bisnis Anda. Ada banyak cara untuk menentukan lokasi yang akan menjadi target pasar. Misalnya: berdasarkan kota, kabupaten, provinsi, atau bisa juga berdasarkan radius. Jangan mendefinisikan target lokasi terlalu umum atau luas. Kesalahan ini biasanya terjadi pada toko online yang hanya menyebutkan "Seluruh Indonesia" sebagai target pasarnya.

Pemilihan lokasi target pasar tidak sama dengan lokasi mana yang dijangkau oleh kurir 
pengiriman barang Anda. Jika toko online Anda memang melayani pengiriman barang ke seluruh Indonesia, minimal buatlah prioritas lokasi yang Anda bidik.

2. Tentukan Karakteristik Demografi Pelanggan Anda Setelah faktor geografi selanjutnya adalah demografi. Kelompokan pelanggan potensial Anda berdasarkan jenis kelamin, usia, agama, pendidikan, pekerjaan, penghasilan, dan faktor demografi lainnya. Anda tidak perlu menggunakan semua contoh di atas, yang penting sudah mendefiniskan siapa pelanggan potensial Anda.

\section{Cari Tahu Bagaimana Psikologis Pelanggan Anda}

Segmentasi pelanggan berdasarkan faktor psikologis atau psikografis ini adalah segmentasi yang paling banyak ragamnya. Kepribadian, kebiasaan, sikap, dan cara pengambilan keputusan adalah beberapa faktor psikografis yang bisa menjadi segmentasi pasar tersendiri. Menargetkan anak-anak "alay" misalnya, itu adalah contoh segmentasi psikografis.

\section{Produk yang Dijual:}

Pakaian Anak-anak, dijual secara online

\section{Target Lokasi:}

Kota-kota besar seperti Jakarta, Bandung, Surabaya, dan kota lain yang dapat dijangkau oleh kurir pengiriman barang maksimal dalam 3 hari.

promosi yang tepat.

Sekarang cobalah untuk membuat target pasar untuk bisnis Anda pada lembar kerja terlampir berikut ini. 


\section{Modul I}

\section{Sistem Manajemen Mutu Bahan Baku / Alat Kerja}

Penjelasan Umum Modul

18. Modul Sistem Manajemen Mutu Bahan Baku / Alat Kerja

\subsubsection{Pemahaman Umum Manajemen Mutu Bahan Baku / Alat Kerja}

\subsubsection{Manfaat Manajemen Mutu Bahan Baku / Alat Kerja}

\subsubsection{Langkah - Langkah melakukan Manajemen Mutu Bahan Baku / Alat Kerj}

Output:

1. Peserta memahami apa itu Manajemen Mutu Bahan Baku

2. Peserta memahami manfaat Manajemen Mutu Bahan Baku / Alat Kerja

3. Peserta memahami langkah-langkah umum menuliskan dan melakukan Manajemen Mutu Bahan Baku / Alat Kerja

Estimasi durasi untuk mengerjakan secara mandiri : 2-4 jam

Dukungan yang dibutuhkan :

o Pendampingan Mentor untuk penulisan langkah- langkah Manajemen Mutu Bahan Baku /

\section{Alat Kerja}

o Audit panduan Manajemen Mutu Bahan Baku / Alat Kerja

o Membahas bersama UKM lain, Manajemen Mutu Bahan Baku / Alat Kerja masing-masing

\section{Modul Sistem Manajemen Mutu Bahan Baku / Alat Kerja}

Ketika Anda memulai modul ini, seharusnya Anda sudah membaca dan mengerjakan modul berikut:

1. Merumuskan Standar Produk/Jasa

2. Menyusun Standar Proses Produksi / Langkah Kerja

3. Menyusun Standar Bahan Baku / Alat Kerja

4. Manajemen Mutu

Jika belum, silakan Anda baca dan kerjakan dahulu modul yang masih terlewat. Jika sudah, semua yang Anda baca dan kerjakan di modul terdahulu akan kita gunakan pada modul ini dan selanjutnya.

Setelah Anda memahami konsep dasar Manajemen Mutu dan melihat berbagai contoh formulirnya, kita akan fokus mengembangkan Manajemen Mutu Bahan Baku / Alat Kerja. 


\section{Contoh Pembuatan \& Pengisian Formulir Kendali Bahan Baku / Alat Kerja}

\section{Langkah 1}

\begin{tabular}{|l|l|l|l|}
\hline Nomor Formulir : 1.1 & Diisi oleh : [nama yang mengisi] & \\
\hline No. Urut & Bahan Baku/ Alat Kerja & Standar Kualitas/Spesifikasi & Terpenuhi \\
\hline 1 & & & \\
\hline 3 & & & \\
\hline Hasil Kendali Kesesuaian dengan Standar & _ dari _ \\
\hline \begin{tabular}{ll|l} 
Dicek oleh: [nama orang yang \\
memeriksa] Hasil Pemeriksaan: \\
Sesuai/Tidak Sesuai
\end{tabular} & Tanggal pengisian : & \\
\cline { 2 - 3 } & Tanggal : Pemeriksaaan &
\end{tabular}

Pada bagian yang diberi warna hijau, tuliskan nomor kode formulir yang akan UKM Anda tetapkan untuk proses kendali Standar Bahan Baku / Alat Kerja. Untuk mempermudah, saran kami beri nomor kode 1.1, bila kemudian UKM Anda mengembangkan formulir baru, lanjutkan penomoran/kode menjadi 1.2, 1.3 dan seterusnya.

\section{Langkah 2}

\begin{tabular}{|l|l|l|l|}
\hline \multicolumn{2}{|l|}{ Nomor Formulir : 1.1 } & \multicolumn{2}{l|}{ Diisi oleh : [nama yang mengisi] } \\
\hline No. Urut & Bahan Baku/ Alat Kerja & Standar Kualitas/Spesifikasi & Terpenuhi \\
\hline 1 & & & \\
\hline 2 & & & \\
\hline 3 & & & \\
\hline Hasil Kendali Kesesuaian dengan Standar & dari _ \\
\hline $\begin{array}{l}\text { Dicek oleh: [nama orang yang } \\
\text { memeriksa] Hasil Pemeriksaan: } \\
\text { Sesuai/Tidak Sesuai }\end{array}$ & Tanggal pengisian : & \\
\cline { 2 - 4 } & &
\end{tabular}

Pada bagian ini yang sekarang diwarnai hijau, sebaiknya diisi oleh orang/staf UKM Anda yang tugasnya berhubungan langsung dengan pengadaan Bahan Baku / Pemeliharaan Alat Kerja. Bisa jadi orangnya bukan 1, tetapi harus jelas siapa saja yang bertanggung jawab untuk mengisi lembar ini. 


\section{Langkah 3}

Nomor Formulir : 1.1

Diisi oleh : [nama yang mengisi]

\section{No. Urut Bahan Baku/ Alat Kerja Standar Kualitas/Spesifikasi Terpenuhi}

1

2

3

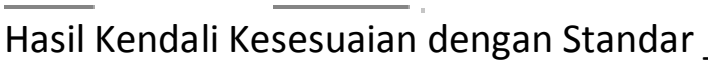

dari

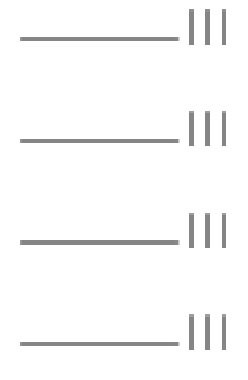

Dicek oleh: [nama orang yang memeriksa] Hasil Pemeriksaan: Sesuai/Tidak Sesuai

Tanggal pengisian :

Tanggal : Pemeriksaaan

Pada bagian ini yang sekarang diwarnai hijau, merupakan bagian yang diisi dengan nomor urut Bahan Baku / Alat Kerja. Jumlah nomor urut tergantung berapa banyak Bahan Baku / Alat Kerja yang tercantum di daftar/ Standar Bahan Baku / Alat Kerja yang sudah Anda tuliskan sebelumnya. Tambahkan sesuai dengan jumlah dan urutan Bahan Baku / Alat Kerja di daftar Anda

Langkah 4

Nomor Formulir : 1.1 Diisi oleh : [nama yang mengisi]

No. Urut Bahan Baku/ Alat Kerja Standar Kualitas/Spesifikasi Terpenuhi

1

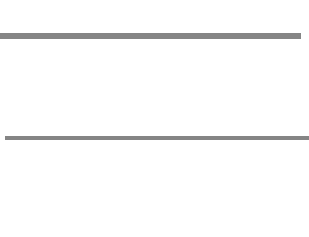

3

Hasil Kendali Kesesuaian dengan Standar _ dari

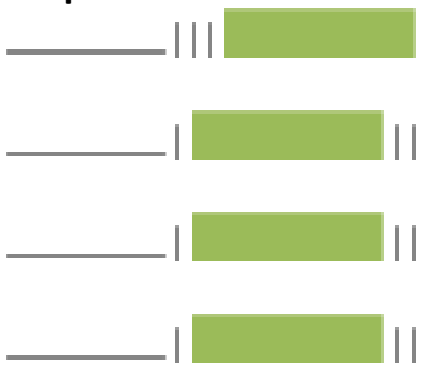

Dicek oleh: [nama orang yang memeriksa] Hasil Pemeriksaan: Sesuai/Tidak Sesuai Tanggal pengisian :

Tanggal : Pemeriksaaan

156 Kemendagri - sylabus - 2018 
Pada bagian ini yang sekarang diwarnai hijau, merupakan bagian yang diisi nama-nama/daftar bahan baku sesuai yang sudah Anda tulis di Standar Bahan Baku / Alat Kerja. Tambahkan baris sesuai dengan jumlah Bahan Baku / Alat Kerja, sampai semuanya terdaftar di form ini

\section{Langkah 5}

Nomor Formulir : 1.1

Diisi oleh : [nama yang mengisi]

\section{No. Urut Bahan Baku/ Alat Kerja Standar Kualitas/Spesifikasi Terpenuhi}
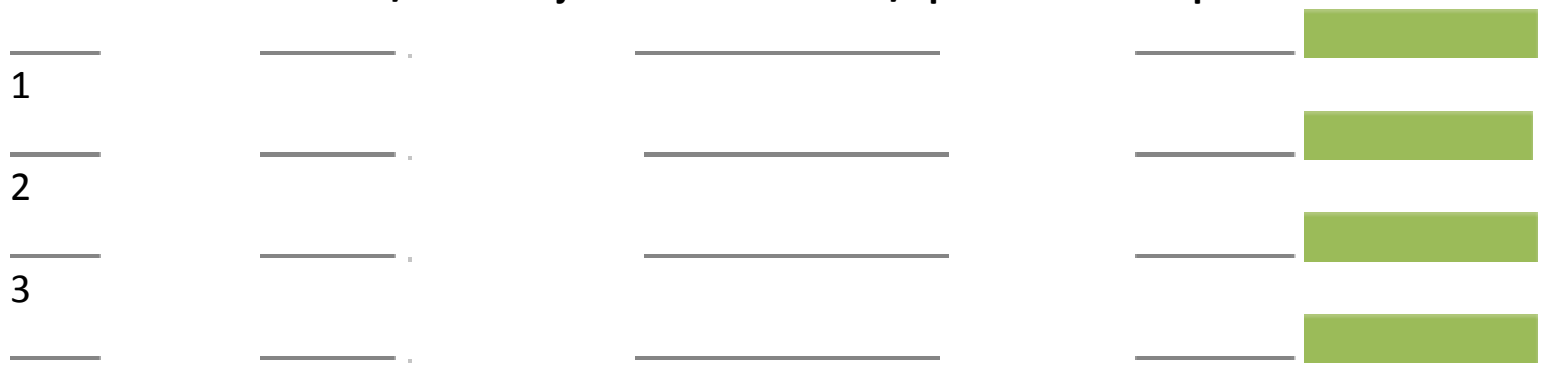

Hasil Kendali Kesesuaian dengan Standard__ dari

Dicek oleh: [nama orang yang memeriksa] Hasil Pemeriksaan: Sesuai/Tida

Pada bagian ini yang sekarang diwarnai hijau, merupakan bagian yang standar kualitas / spesifikasi Bahan Baku / Alat Kerja yang sudah Anda tuliskan di Standar Bahan Baku / Alat Kerja. Biasanya di bagian ini tertulis jumlah, spesifikasi dan kondisi standar ideal atau minimal yang dibutuhkan untuk hasilkan produk yang berkualitas.

\section{Langkah 6}

Nomor Formulir : 1.1

Diisi oleh : [nama yang mengisi]

\section{No. Urut Bahan Baku/ Alat Kerja Standar Kualitas/Spesifikasi Terpenuhi}

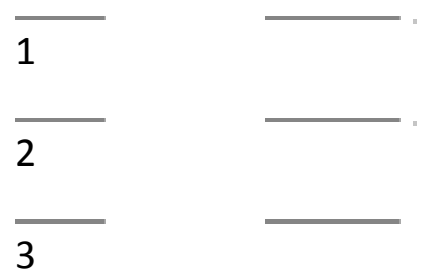

Hasil Kendali Kesesuaian dengan Standar _ dari 
Dicek oleh: [nama orang yang memeriksa] Hasil Pemeriksaan: Sesuai/Tidak Sesuai Tanggal pengisian :

Tanggal : Pemeriksaaan

Pada bagian ini yang sekarang diwarnai hijau, merupakan bagian di mana orang yang mengisi harus memberi tanda apakah Bahan Baku / Alat Kerja yang ia periksa/sekarang ada di hadapannya, sudah memenuhi Standar Kualitas. Beri tanda $\checkmark$ bila memenuhi Standar Bahan Baku / Alat Kerja yang sudah Anda tuliskan sebelumnya. Beri tanda $\square$ X bila tidak memenuhi.

\section{Langkah 7}

\begin{tabular}{|c|c|c|c|}
\hline Nomor For & & oleh : [nama yang meng & \\
\hline No. Urut & $\begin{array}{l}\text { Bahan Baku/ Alat } \\
\text { Kerja }\end{array}$ & $\begin{array}{l}\text { Standar } \\
\text { Kualitas/Spesifikasi }\end{array}$ & Terpenuhi \\
\hline 1 & & & $\checkmark$ \\
\hline 2 & & & $\checkmark$ \\
\hline 3 & & & $x$ \\
\hline Hasil Kend & uaian dengan Standar & & _ dari _ \\
\hline $\begin{array}{l}\text { Dicek ol } \\
\text { memeriksa }\end{array}$ & $\begin{array}{ll}\text { ama } & \text { orang yang } \\
\text { asil } & \text { Pemeriksaan: }\end{array}$ & Tanggal pengisian : & \\
\hline Sesuai/Tid & & Tanggal : Pemeriksaaan & \\
\hline
\end{tabular}

Pada bagian ini yang sekarang diwarnai hijau, merupakan bagian di mana orang yang mengisi harus menghitung, ada berapa tanda $\checkmark$ dari keseluruhan jumlah Bahan Baku yang terdaftar. Dalam contoh ini misalnya, 2 dari 3.

\section{Langkah 8}

Pada bagian ini yang sekarang diwarnai hijau, merupakan bagian di mana ada orang (selain yang mengisi) yang bertanggung jawab untuk memeriksa apakah formulir isian ini telah diisi dengan secara sesuai (antara isian dengan kondisi Bahan Baku / Alat Kerja yang sebenarnya). Yang melakukan pemeriksaan sebaiknya adalah seseorang yang menjadi atasan dari orang yang bertanggung jawab langsung atas pengadaan bahan baku / pemeliharaan alat kerja. 


\begin{tabular}{|c|c|c|c|}
\hline \multicolumn{2}{|c|}{ Nomor Formulir : 1.1} & \multicolumn{2}{|c|}{ Diisi oleh : [nama yang mengisi] } \\
\hline No. Urut & $\begin{array}{l}\text { Bahan Baku/ Alat } \\
\text { Kerja }\end{array}$ & $\begin{array}{l}\text { Standar } \\
\text { Kualitas/Spesifikasi }\end{array}$ & Terpenuhi \\
\hline 1 & & & $\checkmark$ \\
\hline 2 & & & $\checkmark$ \\
\hline 3 & & & $x$ \\
\hline \multicolumn{3}{|c|}{ Hasil Kendali Kesesuaian dengan Standar } & _dari \\
\hline \multirow{2}{*}{\multicolumn{2}{|c|}{$\begin{array}{l}\text { Dicek oleh: [nama orang yang memeriksa] Hasil } \\
\text { Pemeriksaan: Sesuai/Tidak Sesuai }\end{array}$}} & \multicolumn{2}{|l|}{ Tanggal pengisian : } \\
\hline & & \multicolumn{2}{|c|}{ Tanggal : Pemeriksaaan } \\
\hline
\end{tabular}

\section{Langkah 9}

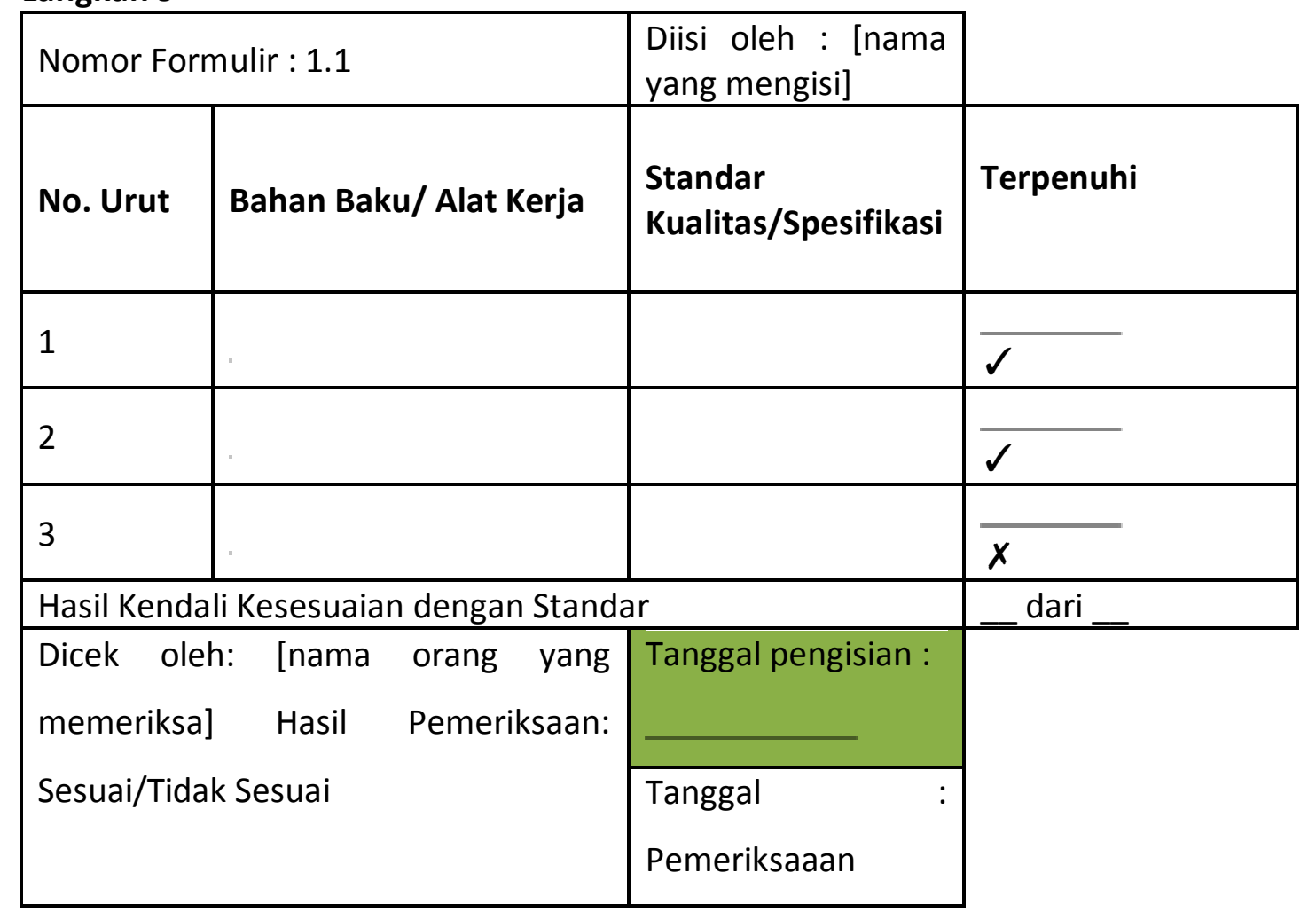

Pada bagian ini yang sekarang diwarnai hijau, merupakan bagian diisi dengan tanggal formulir ini diisi untuk memeriksa Bahan Baku / Alat Kerja

\section{Langkah 10}

Pada bagian ini yang sekarang diwarnai hijau, merupakan bagian diisi dengan tanggal formulir 


\begin{tabular}{|c|c|c|c|}
\hline \multicolumn{2}{|c|}{ Nomor Formulir : 1.1} & \multicolumn{2}{|c|}{ Diisi oleh : [nama yang mengisi] } \\
\hline No. Urut & $\begin{array}{l}\text { Bahan Baku/ } \\
\text { Alat Kerja }\end{array}$ & $\begin{array}{l}\text { Standar } \\
\text { Kualitas/Spesifikasi }\end{array}$ & $\overline{\text { Terpenuhi }}$ \\
\hline 1 & & & $\sqrt{ }$ \\
\hline 2 & & & $\checkmark$ \\
\hline 3 & & & $x$ \\
\hline \multicolumn{3}{|c|}{ Hasil Kendali Kesesuaian dengan Standar } & _dari _ \\
\hline \multirow{3}{*}{\multicolumn{2}{|c|}{$\begin{array}{l}\text { Dicek oleh: [nama orang yang } \\
\text { memeriksa] Hasil Pemeriksaan: } \\
\text { Sesuai/Tidak Sesuai }\end{array}$}} & \multirow{2}{*}{\multicolumn{2}{|c|}{ Tanggal : pengisian }} \\
\hline & & & \\
\hline & & \multicolumn{2}{|l|}{ Tanggal : Pemeriksaaan } \\
\hline
\end{tabular}

ini diperiksa oleh Pengecek.

Formulir ini harus dibiasakan untuk diisi secara teratur, misalnya:

- Formulir Kendali Bahan Baku / Alat Kerja, diisi setiap sebelum proses produksi atau kegiatan kerja dimulai

- Lalu dicek segera sebelum proses produksi atau kegiatan kerja dimulai

Formulir yang sudah terisi, sebaiknya diarsipkan/disimpan sesuai dengan tanggal pengisian dan/ disatukan dengan Formulir Kendali Proses Produksi / Langkah Kerja dan Formulir Kendali Hasil Akhir utk periode produksi / kegiatan jasa yang sama (hari yang sama, minggu yang sama atau bulan yang sama)

Selamat! Ini langkah tambahan agar UKM Anda memiliki kualitas yang baik dan konsisten. Setelah mengerjakan Modul ini, Anda seharusnya sudah:

o memahami apa itu Manajemen Mutu Bahan Baku / Alat Produksi

o Memahami langkah-langkah pengisian Formulir Kendali Mutu Bahan Baku / Alat Produksi

Bila ada yang belum anda pahami dan, mohon tandai dengan ' $x$ 'di daftar di atas. Tuliskan di kotak bawah, hal-hal yang masih Anda anggap kurang jelas atau Anda ingin ketahui lebih lanjut:

Pertanyaan- pertanyaan saya: 
\begin{tabular}{|l|l|}
\hline & \\
\hline
\end{tabular}

Lalu hubungi Tim Pendamping terdekat.

Anda siap untuk melanjutkan ke Modul selanjutnya!

Modul 1

19. Sistem Manajemen Mutu Proses Produksi / Langkah Kerja

\section{Penjelasan Umum Modul}

19. Modul Sistem Manajemen MutuProses Produksi / Langkah Kerja

161 Kemendagri - sylabus - 2018 
19.1. Pemahaman Umum Manajemen MutuProses Produksi / Langkah Kerja

19.2. Manfaat Manajemen MutuProses Produksi / Langkah Kerja

19.3. Langkah - Langkah melakukan Manajemen MutuProses Produksi / Langkah Kerja Output:

- Peserta memahami apa itu Manajemen MutuProses Produksi / Langkah Kerja

- Peserta memahami manfaat Manajemen MutuProses Produksi / Langkah Kerja

- Peserta memahami langkah-langkah umum menuliskan dan melakukan Manajemen MutuProses Produksi / Langkah Kerja

Estimasi durasi untuk mengerjakan secara mandiri : 2-4 jam

Dukungan yang dibutuhkan:

o Pendampingan Mentor untuk penulisan langkah- langkah Manajemen Mutu Proses Produksi / Langkah Kerja

- Audit panduan Manajemen MutuProses Produksi / Langkah Kerja

o Membahas bersama UKM lain, Manajemen MutuProses Produksi / Langkah Kerjamasingmasing

\section{Modul Sistem Manajemen Mutu Bahan Baku / Alat Kerja}

Ketika Anda memulai modul ini, seharusnya Anda sudah membaca dan mengerjakan modul berikut:

1. Merumuskan Standar Produk/Jasa

2. Menyusun Standar Proses Produksi / Langkah Kerja

3. Menyusun Standar Bahan Baku / Alat Kerja

4. Manajemen Mutu

Jika belum membaca dan mengerjakan modul tersebut, silakan Anda baca dan kerjakan dahulu modul yang masih terlewat. Jika sudah, semua yang Anda baca dan kerjakan di modul terdahulu akan kita gunakan pada modul ini dan selanjutnya.

Setelah Anda memahami konsep dasar Manajemen Mutu dan melihat berbagai contoh formulirnya, kita akan fokus mengembangkan Manajemen Mutu Proses Produksi / Langkah 
Kerja.

Contoh Pembuatan \& Pengisian Formulir Kendali Proses Produksi / Langkah Kerja Langkah 1

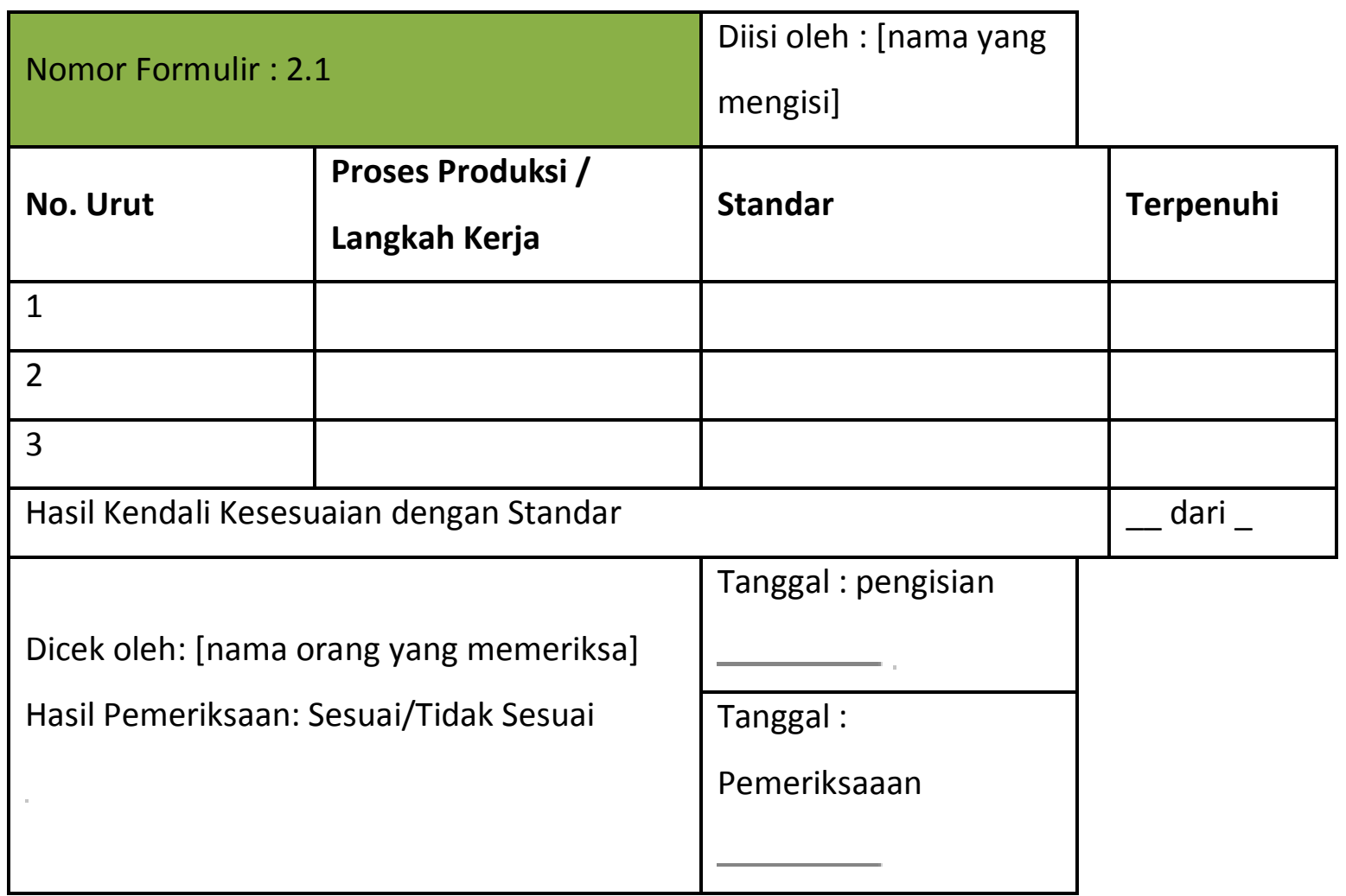

Pada bagian yang diberi warna hijau, tuliskan nomor kode formulir yang akan UKM Anda tetapkan untuk proses kendali Standar Proses Produksi / Langkah Kerja. Untuk mempermudah, saran kami beri nomor kode 1.1, bila kemudian UKM Anda mengembangkan formulir baru, lanjutkan penomoran/kode menjadi 1.2, 1.3 dan seterusnya.

Langkah 2

Nomor Formulir : 2.1

Diisi oleh : [nama yang mengisi] 


\begin{tabular}{|l|l|l|l|}
\hline \multirow{2}{*}{ No. Urut } & Proses Produksi / Langkah Kerja & Standar & Terpenuhi \\
\hline 1 & & & \\
\hline 2 & & & \\
\hline 3 & & & _ dari \\
\hline \multicolumn{2}{|l|}{$\begin{array}{l}\text { Hasil Kendali Kesesuaian dengan Standar } \\
\text { Hasil Pemeriksaan: Sesuai/Tidak Sesuai }\end{array}$} & Tanggal : pengisian & \\
\cline { 2 - 3 } & & & \\
\hline
\end{tabular}

Pada bagian ini yang sekarang diwarnai hijau, sebaiknya diisi oleh orang/staf UKM Anda yang tugasnya berhubungan langsung dengan proses produksi. Bisa jadi orangnya bukan hanya 1 orang, tetapi harus jelas siapa saja yang bertanggung jawab untuk mengisi lembar ini bahkan bila bergantian.

\section{Langkah 3}

Nomor Formulir : 2.1

Diisi oleh : [nama yang mengisi]

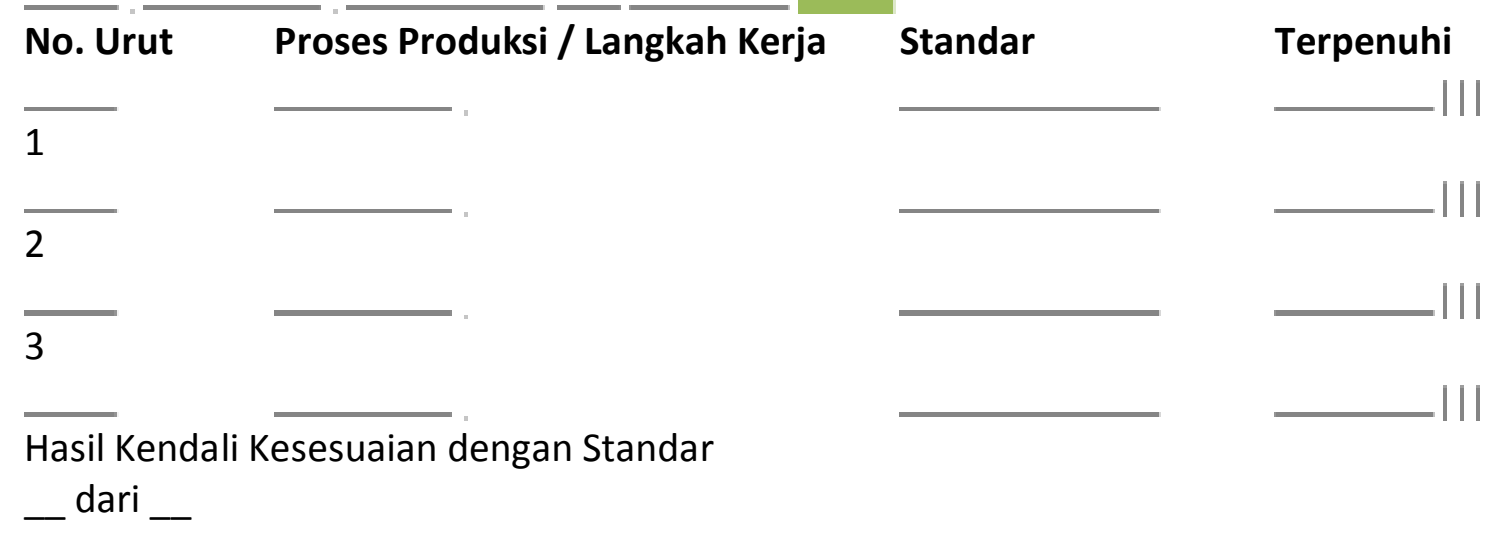

Dicek oleh: [nama orang yang memeriksa]

Hasil Pemeriksaan: Sesuai/Tidak Sesuai

Tanggal : pengisian

Tanggal : Pemeriksaaan

Pada bagian ini yang sekarang diwarnai hijau, merupakan bagian yang diisi dengan nomor urut Proses Produksi / Langkah Kerja. Jumlah nomor urut tergantung berapa banyak Bahan 164 Kemendagri - sylabus - 2018 
Baku / Alat Kerja yang tercantum di daftar Standar Proses Produksi / Langkah Kerjayang sudah Anda tuliskan sebelumnya. Tambahkan sesuai dengan jumlah dan urutan Proses Produksi / Langkah Kerja di daftar Anda.

\section{Langkah 4}

Nomor Formulir : 2.1

Diisi oleh : [nama yang mengisi]

\section{No. Urut}

Proses

1

2

3

Hasil Kendali Kesesuaian dengan Standar dari

Dicek oleh: [nama orang yang memeriksa]

Hasil Pemeriksaan: Sesuai/Tidak Sesuai

Tanggal : pengisian

Tanggal : Pemeriksaaan
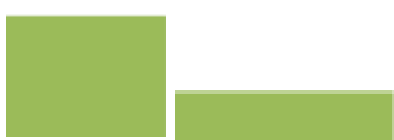

\section{Terpenuhi}

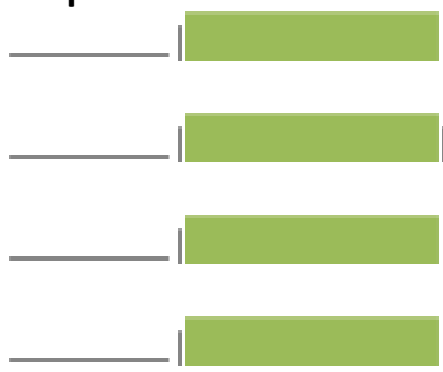

Pada bagian ini yang sekarang diwarnai hijau, merupakan bagian yang diisi nama-nama/daftar bahan baku sesuai yang sudah Anda tulis di Standar Proses Produksi / Langkah Kerja. Tambahkan baris sesuai dengan jumlah tahapan Proses Produksi / Langkah Kerja, sampai semuanya terdaftar di form ini

\section{Langkah 5}

Nomor Formulir : 2.1

165 Kemendagri - sylabus - 2018 
Diisi oleh : [nama yang mengisi]

No. Urut Proses Produksi / Langkah Kerja Standar Terpenuhi

1

2

3

Hasil Kendali Kesesuaian dengan Standar

- dari

Dicek oleh: [nama orang yang memeriksa]

Hasil Pemeriksaan: Sesuai/Tidak Sesuai

Tanggal : pengisian

Tanggal : Pemeriksaaan

Pada bagian ini yang sekarang diwarnai hijau, merupakan bagian yang standar kualitas / spesifikasi Bahan Baku / Alat Kerja yang sudah Anda tuliskan di Standar Proses Produksi / Langkah Kerja. Biasanya di bagian ini tertulis durasi pengerjaan atau hasil kerja minimal direncanakan.

\section{Langkah 6}

Nomor Formulir : 2.1

166 Kemendagri - sylabus - 2018 
Diisi oleh : [nama yang mengisi]

\section{No. Urut Proses Produksi / Langkah Kerja Standar Terpenuhi}

1

2
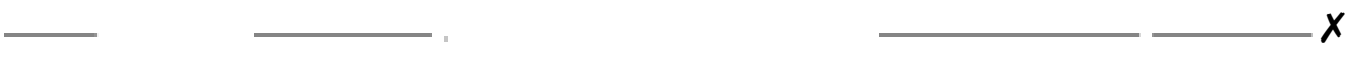

3

Hasil Kendali Kesesuaian dengan Standar

_ dari

Dicek oleh: [nama orang yang memeriksa]

Hasil Pemeriksaan: Sesuai/Tidak Sesuai

Tanggal : pengisian

Tanggal : Pemeriksaaan

Pada bagian ini yang sekarang diwarnai hijau, merupakan bagian di mana orang yang mengisi harus memberi tanda apakah Standar Proses Produksi / Langkah Kerja yang ia kerjakan, sudah memenuhi Standar Kualitas yang diharapkan. Beri tanda $\checkmark$ bila memenuhi Standar Proses Produksi / Langkah Kerjayang sudah Anda tuliskan sebelumnya. Beri tanda $x$ bila tidak memenuhi.

\section{Langkah 7}

\begin{tabular}{|l|l|l|l|}
\hline \multicolumn{2}{|l|}{ Nomor Formulir : 2.1 } & \multicolumn{2}{l|}{ Diisi oleh : [nama yang mengisi] } \\
\hline No. Urut & $\begin{array}{l}\text { Proses Produksi / } \\
\text { Langkah Kerja }\end{array}$ & Standar & Terpenuhi \\
\hline
\end{tabular}




\begin{tabular}{|c|c|c|}
\hline 1 & & $\checkmark$ \\
\hline 2 & & $\checkmark$ \\
\hline 3 & & $x$ \\
\hline \multicolumn{2}{|c|}{ Hasil Kendali Kesesuaian dengan Standar } & _ dari $^{\text {d }}$ \\
\hline \multirow{2}{*}{\multicolumn{2}{|c|}{$\begin{array}{l}\text { Dicek oleh: [nama orang yang memeriksa] } \\
\text { Hasil Pemeriksaan: Sesuai/Tidak Sesuai }\end{array}$}} & Tanggal : pengisian \\
\hline & & Tanggal : Pemeriksaaan \\
\hline
\end{tabular}

Pada bagian ini yang sekarang diwarnai hijau, merupakan bagian di mana orang yang mengisi harus menghitung, ada berapa tanda $\checkmark$ dari keseluruhan jumlah Bahan Baku yang terdaftar. Dalam contoh ini misalnya, 2 dari 3.

\section{Langkah 8}

\begin{tabular}{|c|c|c|c|}
\hline \multicolumn{2}{|c|}{ Nomor Formulir : 2.1} & \multicolumn{2}{|c|}{ Diisi oleh : [nama yang mengisi] } \\
\hline No. Urut & $\begin{array}{l}\text { Proses Produksi / } \\
\text { Langkah Kerja }\end{array}$ & Standar & $\overline{\text { Terpenuhi }}$ \\
\hline 1 & & & $\checkmark$ \\
\hline 2 & & & $\checkmark$ \\
\hline 3 & & & $x$ \\
\hline \multicolumn{3}{|c|}{ Hasil Kendali Kesesuaian dengan Standar } & _ dari _ \\
\hline \multirow{2}{*}{\multicolumn{2}{|c|}{$\begin{array}{l}\text { Dicek oleh: [nama orang yang memeriksa] } \\
\text { Hasil Pemeriksaan: Sesuai/Tidak Sesuai }\end{array}$}} & \multicolumn{2}{|c|}{ Tanggal : pengisian } \\
\hline & & \multicolumn{2}{|c|}{ Tanggal : Pemeriksaaan } \\
\hline
\end{tabular}

Pada bagian ini yang sekarang diwarnai hijau, merupakan bagian di mana ada orang (selain yang mengisi) yang bertanggung jawab untuk memeriksa apakah formulir isian ini telah diisi dengan secara sesuai (antara isian dengan kondisi Proses Produksi / Langkah Kerja yang sebenarnya). Yang melakukan pemeriksaan sebaiknya adalah seseorang yang menjadi atasan dari orang yang bertanggung jawab langsung atas produksi / kerja 


\section{Langkah 9}

\begin{tabular}{|c|c|c|c|}
\hline \multicolumn{2}{|c|}{ Nomor Formulir : 2.1} & \multirow{2}{*}{$\begin{array}{l}\text { Diisi oleh : [nama yang mengisi] } \\
\text { Standar }\end{array}$} & \multirow[b]{2}{*}{ Terpenuhi } \\
\hline No. Urut & $\begin{array}{l}\text { Proses Produksi / } \\
\text { Langkah Kerja }\end{array}$ & & \\
\hline 1 & & & $\checkmark$ \\
\hline 2 & & & $\checkmark$ \\
\hline 3 & & & $x$ \\
\hline \multicolumn{3}{|c|}{ Hasil Kendali Kesesuaian dengan Standar } & _ dari _ \\
\hline \multirow{2}{*}{\multicolumn{2}{|c|}{$\begin{array}{l}\text { Dicek oleh: [nama orang yang } \\
\text { memeriksa] Hasil Pemeriksaan: } \\
\text { Sesuai/Tidak Sesuai }\end{array}$}} & Tanggal : pengisian & \\
\hline & & Tanggal : Pemeriksaaan & \\
\hline
\end{tabular}

Pada bagian ini yang sekarang diwarnai hijau, merupakan bagian diisi dengan tanggal formulir ini diisi untuk memeriksa Proses Produksi / Langkah Kerja

Langkah 10

\begin{tabular}{|c|c|c|c|}
\hline \multicolumn{2}{|c|}{ Nomor Formulir : 2.1} & $\begin{array}{l}\text { Diisi oleh : [nama } \\
\text { yang mengisi] }\end{array}$ & \\
\hline No. Urut & Proses Produksi / Langkah Kerja & Standar & Terpenuhi \\
\hline 1 & & & $\checkmark$ \\
\hline 2 & & & $\checkmark$ \\
\hline 3 & & & $x$ \\
\hline \multicolumn{3}{|c|}{ Hasil Kendali Kesesuaian dengan Standar } & _ dari _ \\
\hline \multirow{2}{*}{\multicolumn{2}{|c|}{$\begin{array}{l}\text { Dicek oleh: [nama orang yang memeriksa] } \\
\text { Hasil Pemeriksaan: Sesuai/Tidak Sesuai }\end{array}$}} & Tanggal : pengisian & \\
\hline & & $\begin{array}{l}\text { Tanggal : } \\
\text { Pemeriksaaan }\end{array}$ & \\
\hline
\end{tabular}

Pada bagian ini yang sekarang diwarnai hijau, merupakan bagian diisi dengan tanggal formulir ini diperiksa oleh Pengecek.

Formulir ini harus dibiasakan untuk diisi secara teratur, misalnya:

- Formulir Kendali Proses Produksi / Langkah Kerja ini, diisi setiap selesai 1 tahap/langkah proses produksi atau kegiatan kerja dimulai 
- Lalu dicek segera sebelum proses produksi atau kegiatan kerja dilanjutkan Formulir yang sudah terisi, sebaiknya diarsipkan/disimpan sesuai dengan tanggal pengisian dan/ disatukan dengan Formulir Kendali Bahan Baku / Alat Produksi dan Formulir Kendali Hasil Akhir utk periode produksi / kegiatan jasa yang sama (hari yang sama, minggu yang sama atau bulan yang sama)

Selamat! Ini langkah tambahan agar UKM Anda memiliki kualitas yang baik dan konsisten. Setelah mengerjakan Modul ini, Anda seharusnya sudah:

o memahami apa itu Manajemen Proses Produksi / Langkah Kerja

o Memahami langkah-langkah pengisian Formulir Kendali Proses Produksi / Langkah Kerja Bila ada yang belum anda pahami dan, mohon tandai dengan ' $x$ 'di daftar di atas. Tuliskan di kotak bawah, hal-hal yang masih Anda anggap kurang jelas atau Anda ingin ketahui lebih lanjut:

Pertanyaan- pertanyaan saya:

Lalu hubungi TIM Pendamping terdekat.

Anda siap untuk melanjutkan ke Modul selanjutnya!

Modul 1

20.Sistem Manajemen MutuHasil Akhir

Penjelasan Umum Modul

20. Modul Sistem Manajemen MutuMutu Hasil Akhir

20.7.1. Pemahaman Umum Manajemen MutuMutu Hasil Akhir

170 Kemendagri - sylabus - 2018 


\subsubsection{Manfaat Manajemen MutuMutu Hasil Akhir}

\subsubsection{Langkah - Langkah melakukan Manajemen MutuMutu Hasil Akhir}

Output:

1. Peserta memahami apa itu Manajemen MutuMutu Hasil Akhir

2. Peserta memahami manfaat Manajemen MutuMutu Hasil Akhir

3. Peserta memahami langkah-langkah umum menuliskan dan melakukan Manajemen MutuMutu Hasil Akhir Estimasi durasi untuk mengerjakan secara mandiri : 2-4 jam Dukungan yang dibutuhkan :

o Pendampingan Mentor untuk penulisan langkah- langkah Manajemen MutuMutu Hasil Akhir

o Audit panduan Manajemen MutuProses Mutu Hasil Akhir

o Membahas bersama UKM lain, Manajemen MutuMutu Hasil Akhirmasing-masing

\section{Modul Sistem Manajemen MutuMutu Hasil Akhir}

Ketika Anda memulai modul ini, seharusnya Anda sudah membaca dan mengerjakan modul berikut:

1. Merumuskan Standar Produk/Jasa

2. Menyusun Standar Proses Produksi / Langkah Kerja

3. Menyusun Standar Bahan Baku / Alat Kerja

4. Manajemen Mutu

Jika belum, silakan Anda baca dan kerjakan dahulu modul yang masih terlewat. Jika sudah, semua yang Anda baca dan kerjakan di modul terdahulu akan kita gunakan pada modul ini dan selanjutnya. Setelah Anda memahami konsep dasar Manajemen Mutu dan melihat berbagai contoh formulirnya, kita akan fokus mengembangkan Manajemen Mutu Proses Produksi / Langkah Kerja.

Contoh Pembuatan \& Pengisian Formulir Kendali Mutu Hasil Akhir Langkah 1

\begin{tabular}{|l|l|l|l|}
\hline \multicolumn{2}{|l|}{ Nomor Formulir : 3.1} & \multicolumn{2}{l|}{ Diisi oleh : [nama yang mengisi] } \\
\hline No. Urut & Kriteria Kualitas & Standar & Terpenuhi \\
\hline
\end{tabular}




\begin{tabular}{|l|l|l|l|}
\hline 1 & Warna & & \\
\hline 2 & Ukuran & & \\
\hline 3 & Berat & & \\
\hline 4 & Kerapihan & & \\
\hline Hasil Kendali Kesesuaian dengan Standar & _ dari _ \\
\hline \multirow{2}{*}{$\begin{array}{l}\text { Dicek oleh: [nama orang yang } \\
\text { memeriksa] } \\
\text { Sesuai }\end{array}$} & Tanggal : pengisian & \\
\cline { 2 - 4 }
\end{tabular}

Pada bagian yang diberi warna hijau, tuliskan nomor kode formulir yang akan UKM Anda tetapkan untuk proses kendali Standar Proses Produksi / Langkah Kerja. Untuk mempermudah, saran kami beri nomor kode 1.1, bila kemudian UKM Anda mengembangkan formulir baru, lanjutkan penomoran/kode menjadi 1.2, 1.3 dan seterusnya.

\section{Langkah 2}

\begin{tabular}{|l|l|l|l|}
\hline \multicolumn{2}{|l|}{ Nomor Formulir : 3.1} & \multicolumn{2}{l|}{ Diisi oleh : [nama yang mengisi] } \\
\hline No. Urut & Kriteria Kualitas & Standar & Terpenuhi \\
\hline 1 & Warna & & \\
\hline 2 & Ukuran & & \\
\hline 3 & Berat & & \\
\hline 4 & Kerapihan & & _dari _ \\
\hline Hasil Kendali Kesesuaian dengan Standar & & \\
\hline $\begin{array}{l}\text { Dicek oleh: [nama orang yang } \\
\text { memeriksa] } \\
\text { Hasil Pemeriksaan: Sesuai/Tidak } \\
\text { Sesuai }\end{array}$ & Tanggal : pengisian & \\
\cline { 2 - 4 } & & & \\
\hline
\end{tabular}

Pada bagian ini yang sekarang diwarnai hijau, sebaiknya diisi oleh orang/staf UKM Anda yang tugasnya berhubungan langsung dengan proses pengiriman atau penjualan produk. Bisa jadi orangnya bukan hanya 1 orang, tetapi harus jelas siapa saja yang bertanggung jawab untuk mengisi lembar ini bahkan bila bergantian.

\section{Langkah 3}


Nomor Formulir : 3.1

Diisi oleh : [nama yang mengisi]

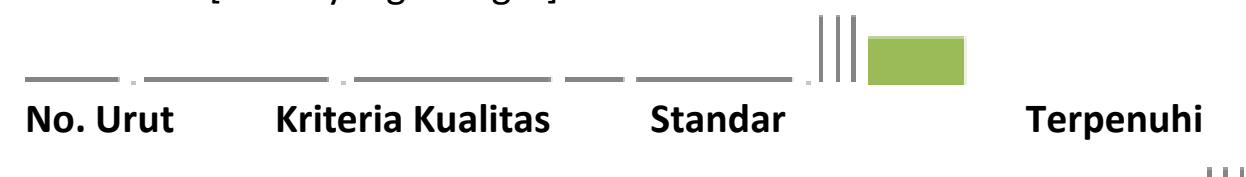

1

Warna

2

Ukuran

3

Berat

4

Kerapihan

Hasil Kendali Kesesuaian dengan Standar

_ dari _

Dicek oleh: [nama orang yang memeriksa]

Hasil Pemeriksaan: Sesuai/Tidak Sesuai

Tanggal : pengisian

Tanggal : Pemeriksaaan

Pada bagian ini yang sekarang diwarnai hijau, merupakan bagian yang diisi dengan nomor urut Kriteria Kualitas. Jumlah nomor urut tergantung berapa banyak Kriteria Kualitas yang tercantum di daftar Standar Kualitas Produk / Jasayang sudah Anda tuliskan sebelumnya. Tambahkan sesuai dengan jumlah dan urutan Standar Kualitas Produk / Jasadi daftar Anda.

Langkah 4

Nomor Formulir : 3.1

Diisi oleh : [nama yang mengisi] 


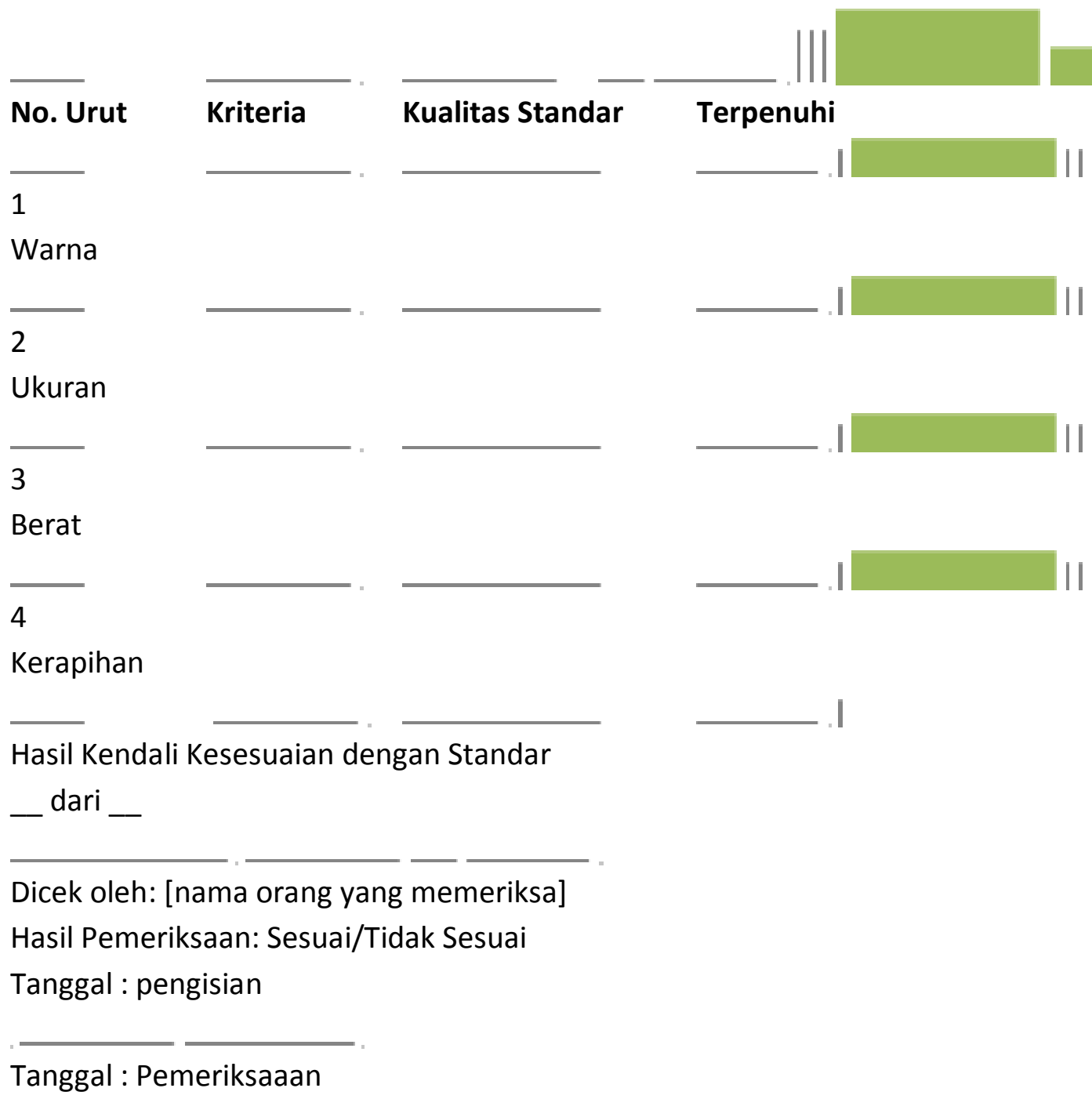

Pada bagian ini yang sekarang diwarnai hijau, merupakan bagian yang diisi Kriteria Kualitas sesuai yang sudah Anda tulis di Standar Produk Akhir / Jasa. Tambahkan baris sesuai dengan jumlah Kriteria Kualitas, sampai semuanya terdaftar di formulir ini

\section{Langkah 5}

Nomor Formulir : 3.1

Diisi oleh : [nama yang mengisi] 


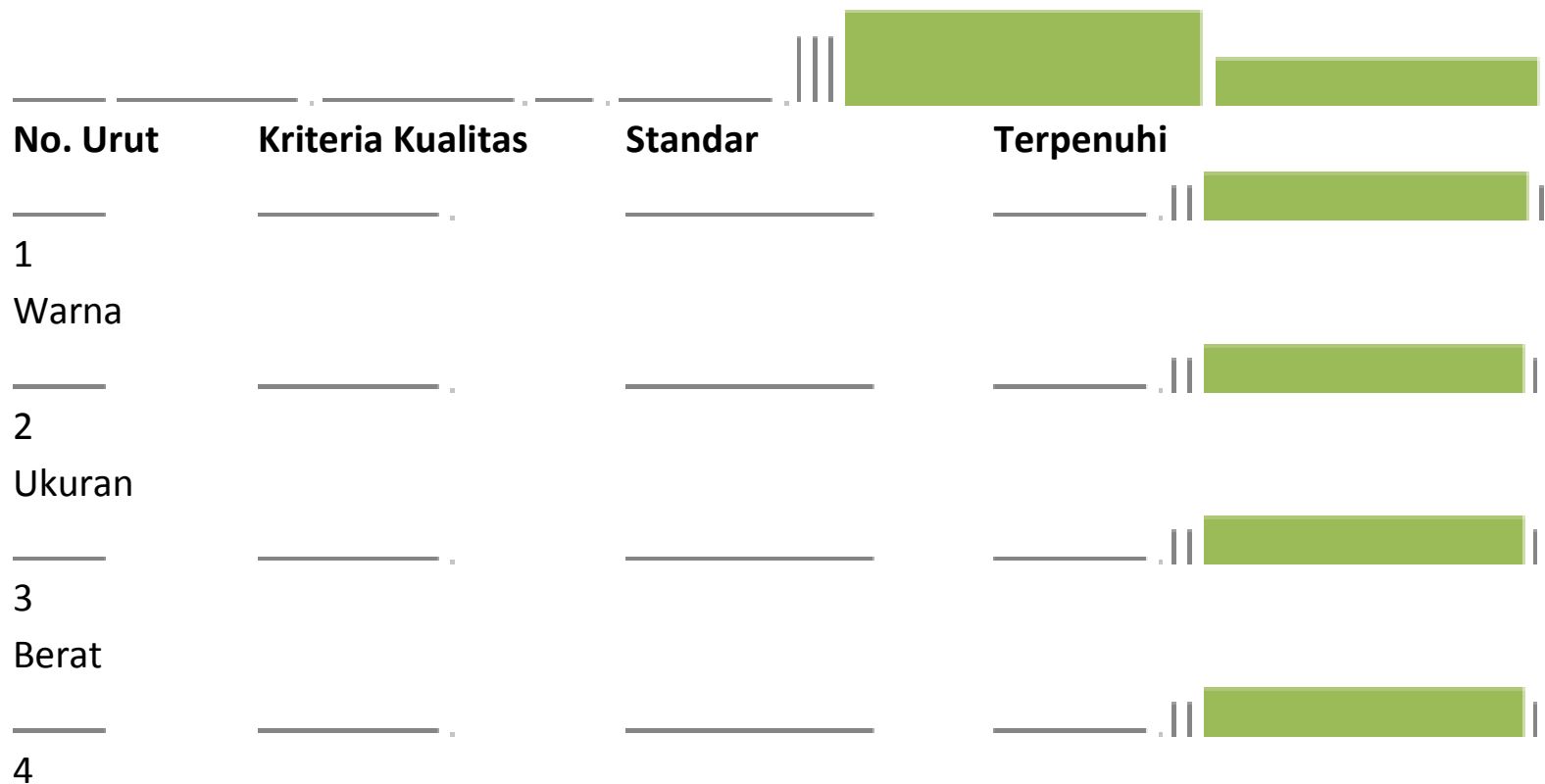

Kerapihan

Hasil Kendali Kesesuaian dengan Standar

_ dari

Dicek oleh: [nama orang yang memeriksa]

Hasil Pemeriksaan: Sesuai/Tidak Sesuai

Tanggal : pengisian

Tanggal : Pemeriksaaan

Pada bagian ini yang sekarang diwarnai hijau, merupakan isian mengenai yang rincian atau cara mengukur kriteria kualitas (misal, kerapihan $1 \mathrm{~s} / \mathrm{d} 10$, warna merah grade 3 , dst) yang sudah Anda tuliskan di Standar Kualitas Produk.

\section{Langkah 6}

Nomor Formulir : 3.1

Diisi oleh : [nama yang mengisi] 


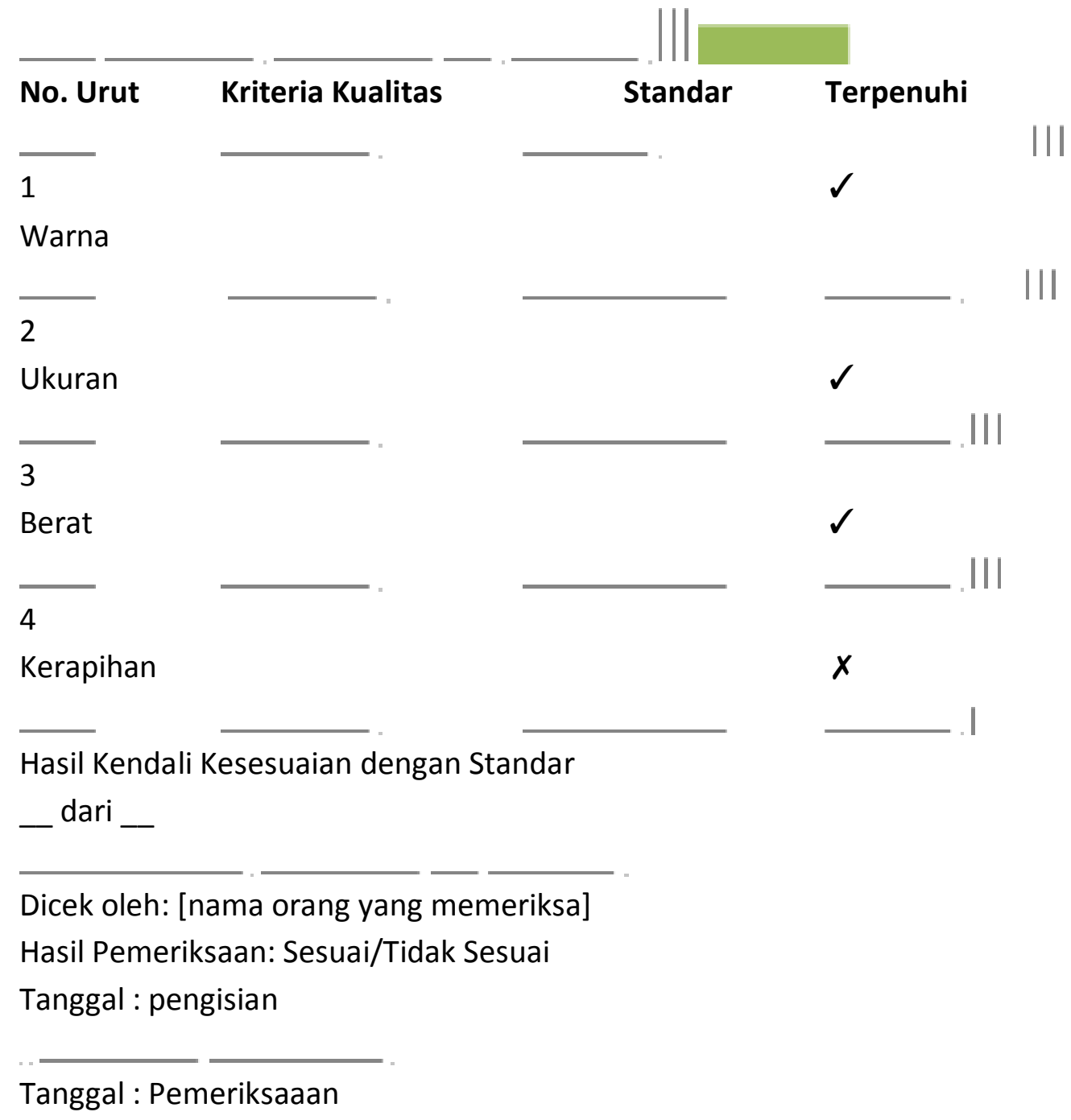

Pada bagian ini yang sekarang diwarnai hijau, merupakan bagian di mana orang yang mengisi harus memberi tanda apakah Produk / Jasa yang ia akan tawarkan kepada konsumen, sudah memenuhi Standar Kualitas yang diharapkan. Beri tanda $\checkmark$ bila memenuhi Standar Produk / Jasa yang sudah Anda tuliskan sebelumnya. Beri tanda $X$ bila tidak memenuhi.

Langkah 7

\begin{tabular}{|l|l|l|l|}
\hline \multicolumn{2}{|l|}{ Nomor Formulir : 3.1} & Diisi oleh : [nama yang mengisi] \\
\hline No. Urut & Kriteria Kualitas & Standar & Terpenuhi \\
\hline 1 & Warna & & $\checkmark$ \\
\hline
\end{tabular}




\begin{tabular}{|l|l|l|l|}
\hline 2 & Ukuran & & $\checkmark$ \\
\hline 3 & Berat & & $\checkmark$ \\
\hline 4 & Kerapihan & & $x$ \\
\hline \multicolumn{2}{|l|}{ Hasil Kendali Kesesuaian dengan Standar } & - dari - \\
\hline $\begin{array}{l}\text { Dicek oleh: [nama orang yang } \\
\text { memeriksa] } \\
\text { Hasil Pemeriksaan: Sesuai/Tidak Sesuai }\end{array}$ & Tanggal : pengisian & \\
\cline { 2 - 4 } & Tanggal : Pemeriksaaan & \\
\hline
\end{tabular}

Pada bagian ini yang sekarang diwarnai hijau, merupakan bagian di mana orang yang mengisi harus menghitung, ada berapa tanda $\checkmark$ dari keseluruhan Kriteria Kualitas yang terdaftar. Dalam contoh ini misalnya, 3 dari 4.

Langkah 8

\begin{tabular}{|l|l|l|l|}
\hline \multicolumn{2}{|l|}{ Nomor Formulir : 3.1} & $\begin{array}{l}\text { Diisi oleh : [nama yang } \\
\text { mengisi] }\end{array}$ & \\
\hline \multirow{2}{*}{ No. Urut } & Kriteria Kualitas & Standar & Terpenuhi \\
\hline 1 & Warna & & $\checkmark$ \\
\hline 2 & Ukuran & & $\checkmark$ \\
\hline 3 & Berat & & $\checkmark$ \\
\hline 4 & Kerapihan & & $x$ \\
\hline Hasil Kendali Kesesuaian dengan Standar & & - dari _ \\
\cline { 1 - 2 } $\begin{array}{l}\text { Dicek oleh: [nama orang yang memeriksa] } \\
\text { Hasil Pemeriksaan: Sesuai/Tidak Sesuai }\end{array}$ & Tanggal : pengisian & \multicolumn{2}{|l}{ Tanggal : Pemeriksaaan } \\
\cline { 2 - 3 }
\end{tabular}

Pada bagian ini yang sekarang diwarnai hijau, merupakan bagian di mana ada orang (selain yang mengisi) yang bertanggung jawab untuk memeriksa apakah formulir isian ini telah diisi dengan secara sesuai (antara isian dengan kondisi Produk Akhir / Jasa yang sebenarnya). Yang melakukan pemeriksaan sebaiknya adalah seseorang yang menjadi atasan dari orang yang bertanggung jawab langsung atas Produk

\section{Langkah 9}

\begin{tabular}{|l|c|l|c|}
\hline \multicolumn{2}{|c|}{ Nomor Formulir : 3.1} & \multicolumn{2}{|c|}{ Diisi oleh : [nama yang mengisi] } \\
\hline No. Urut & Kriteria Kualitas & Standar & Terpenuhi \\
\hline
\end{tabular}

Pada bagian ini yang sekarang diwarnai hijau, merupakan bagian diisi dengan tanggal formulir 177 Kemendagri - sylabus - 2018 


\begin{tabular}{|c|c|c|c|}
\hline & Warna & & $\checkmark$ \\
\hline & Ukuran & & $\checkmark$ \\
\hline & Berat & & $\checkmark$ \\
\hline & Kerapihan & & $x$ \\
\hline \multicolumn{3}{|c|}{ Hasil Kendali Kesesuaian dengan Standar } & _ dari __ \\
\hline \multirow{2}{*}{\multicolumn{2}{|c|}{$\begin{array}{l}\text { Dicek oleh: [nama orang yang memeriksa] } \\
\text { Hasil Pemeriksaan: Sesuai/Tidak Sesuai }\end{array}$}} & \multicolumn{2}{|l|}{ Tanggal : pengisian } \\
\hline & & \multicolumn{2}{|c|}{ Tanggal : Pemeriksaaan } \\
\hline
\end{tabular}

ini diisi untuk memeriksa Produk / Jasa Akhir

\section{Langkah 10}

\begin{tabular}{|l|l|l|l|}
\hline Nomor Formulir : 3.1 & \multicolumn{2}{l|}{ Diisi oleh : [nama yang mengisi] } \\
\hline No. Urut & Kriteria Kualitas & Standar & Terpenuhi \\
\hline 1 & Warna & & $\checkmark$ \\
\hline 2 & & & $\checkmark$ \\
\hline 3 & Ukuran & & $\checkmark$ \\
\hline 4 & Berat & & $\boldsymbol{X}$ \\
\hline Hasil Kendali Kesesuaian dengan Standar & & _ dari _ \\
\hline Dicek oleh: [nama orang yang memeriksa] & \multicolumn{2}{l}{ Tanggal : pengisian } \\
\cline { 2 - 4 } Hasil Pemeriksaan: Sesuai/Tidak Sesuai & Tanggal : Pemeriksaaan \\
\hline
\end{tabular}

Pada bagian ini yang sekarang diwarnai hijau, merupakan bagian diisi dengan tanggal formulir ini diperiksa oleh Pengecek.

Formulir ini harus dibiasakan untuk diisi secara teratur, misalnya:

- Formulir Kendali Proses Produksi / Langkah Kerja ini, segera setelah proses produksi selesai atau setelah Jasa dinikmati pelanggan

Khusus untuk UKM Jasa, penilaian bisa jadi perlu melibatkan konsumen yang menikmati Jasa.

Formulir yang sudah terisi, sebaiknya diarsipkan/disimpan sesuai dengan tanggal pengisian dan/ disatukan dengan Formulir Kendali Bahan Baku / Alat Produksi dan Formulir Kendali Proses Produksi utk periode produksi / kegiatan jasa yang sama (hari yang sama, minggu yang sama atau bulan yang sama)

Selamat! Ini langkah tambahan agar UKM Anda memiliki kualitas yang baik dan konsisten. Setelah mengerjakan Modul ini, Anda seharusnya sudah:

o memahami apa itu Manajemen Kualitas Akhir o Memahami langkah-langkah pengisian

\section{Formulir Kendali Kualitas Akhir}

Bila ada yang belum anda pahami dan, mohon tandai dengan ' $x$ 'di daftar di atas. Tuliskan di 
kotak bawah, hal-hal yang masih Anda anggap kurang jelas atau Anda ingin ketahui lebih lanjut:

Pertanyaan- pertanyaan saya:

Lalu hubungi TIM Pendamping terdekat.

Anda siap untuk melanjutkan ke Modul selanjutnya!

Modul I

21.Penggunaan Internet Dasar 


\section{Pendahuluan Struktur Modul}

4 Dasar-dasar Internet \& browsing

5 Penggunaan Email

\section{Tujuan Modul}

5. Peserta memiliki keahlian dasar dalam browsing

6. Peserta bisa membuat alamat email sendiri

7. Peserta memiliki kemampuan dasar dalam menggunakan email

\section{Dasar-dasar Internet}

\section{Apakah Internet Itu?}

Internet adalah singkatan dari "interconnection- networking" yang pada awalnya merupakan proyek dari Departemen Pertahanan AS untuk menghubungkan komputer-komputer untuk pertukaran data. Pada perkembangannya, internet fungsinya meluas dari yang asalnya untuk keperluan pertahanan menjadi bisa diakses oleh publik.

Sekarang ini, internet adalah jaringan raksasa yang tersebar ke seluruh penjuru dunia yang menghubungkan miliaran komputer, ponsel, dan server untuk bertukar informasi.

Seiring berjalannya waktu, internet juga berkembang dari yang asalnya hanya untuk berbagi informasi yang sekarang bisa digunakan bagi perusahaan maupun UKM untuk mengembangkan bisnisnya, mulai dari sekedar membuat iklan di Google, membuat akun Facebook, hingga bertransaksi secara di layanan pasar online. 


\section{Browser}

New Tab
For quick access, place your bookmarks here on the bookmarks bar. Import bookmarks now...

\section{Google}

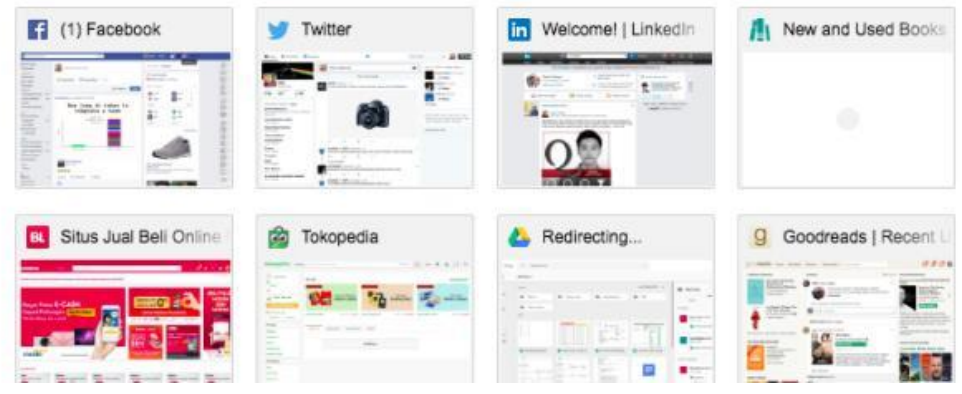

Browser atau Peramban adalah aplikasi di komputer ataupun ponsel Anda yang fungsi utamanya adalah untuk membuka halaman di internet. Tanpa adanya browser, Anda tidak akan bisa membuka email ataupun Facebook di komputer Anda.

Ada beberapa browser yang umum digunakan di dunia ini, di antaranya adalah Google Chrome, Mozilla Firefox, Safari, dan Microsoft Edge.

Untuk modul ini, browser yang akan digunakan adalah Google Chrome yang juga merupakan browser paling populer di dunia.

Jika Anda belum memiliki Google Chrome di komputer Anda, Anda bisa memasangnya dengan mengunduh Google Chrome di google.com/chrome. 


\section{URL \& Kolom Alamat}

URL (uniform resource locator) adalah alamat dari sebuah situs, seperti halnya setiap perusahaan memiliki alamat kantor. URL memungkinkan browser untuk membuka situs tertentu di internet.

Alamat situs biasanya berupa www.namadomain.com. Bagian ' $w w w$ ' tidak wajib untuk Anda ketik, karena biasanya sudah otomatis ditambahkan oleh browser Anda. namadomain.com adalah alamat dari situs internet, seperti halnya alamat perusahaan Anda. Bagian '.com' adalah penanda jenis situs Anda: .com untuk perusahaan (company), .org untuk organisasi bukan perusahaan, .gov untuk pemerintahan (government), dan banyak lagi. Adapun yang paling umum digunakan adalah .com.

Untuk memulai browsing, mari kita mulai membuka Google, yaitu situs pencarian paling populer di dunia. Ketikkan "google.com" di peramban Anda lalu tekan enter.

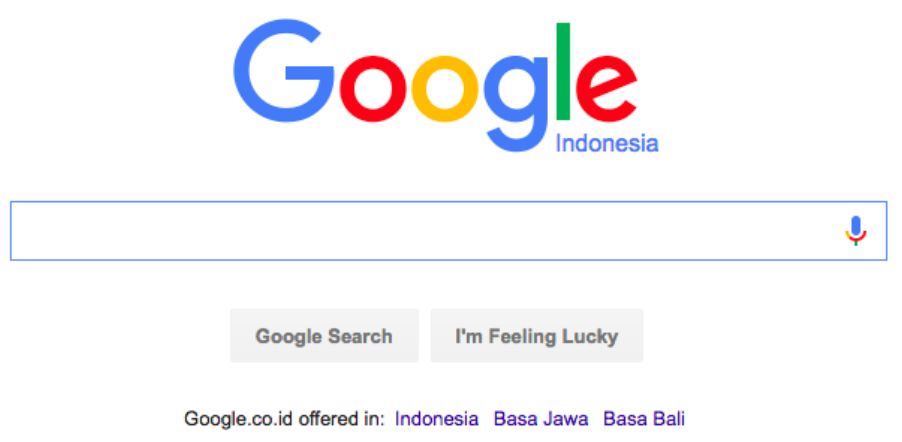

\section{Link/Tautan}

Setiap kali Anda melihat tulisan yang berwarna biru, kemungkinan tulisan itu adalah link/tautan. Link memungkinkan Anda untuk membuka halaman lain tanpa mengetiknya. Terkadang juga link tidak hanya berupa tulisan, tetapi juga gambar. Untuk tahu apakah tulisan atau gambar adalah link, cukup gerakkan mouse ke tulisan atau gambar tersebut, lalu jika panah di kursor berubah menjadi tangan, maka ia adalah link. 


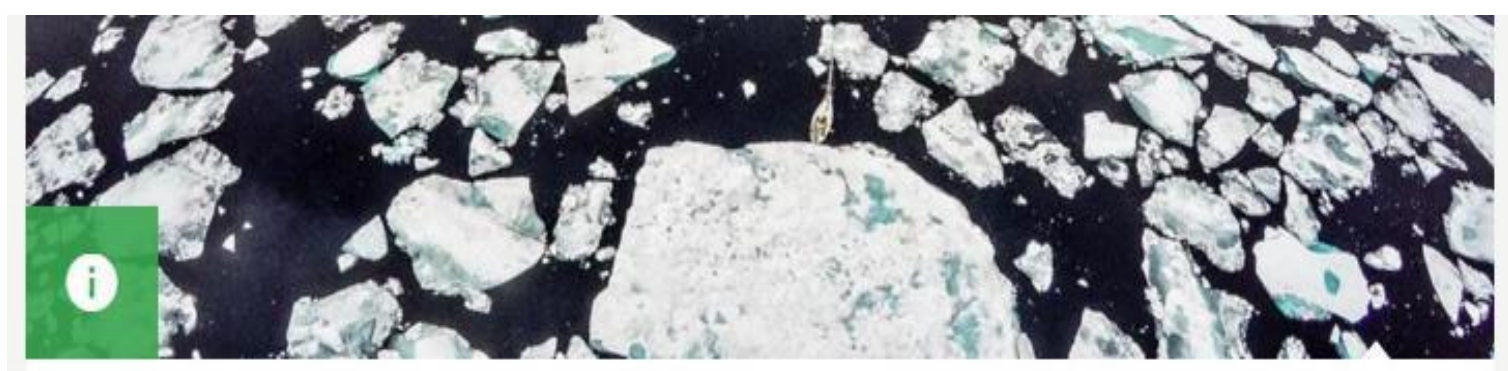

\section{An icy sail to the end of the Earth \\ We travelled $7,500 \mathrm{~km}$ to the Norwegian Arctic in a no-frills sailboat that was better suited for cruising the Mediterranean than penetrating the polar ice.}

\section{Tombol Navigasi}

Tombol di bagian kiri atas browser Anda adalah tombol navigasi, yang memungkinkan Anda untuk pindah ke halaman yang sebelumnya pernah dikunjungi.

Adapun tombol refresh membuat halaman yang sedang dilihat untuk dimuat ulang, ini berguna jika ada error ataupun ada konten yang berubah.

\section{Tabbed Browsing}

Sering kali Anda ingin membuka lebih dari satu halaman. Namun jangan khawatir, karena dengan Google Chrome, Anda bisa membuka lebih dari satu halaman tanpa harus menutup halaman yang lain. Cukup klik tombol di bagian atas, di sebelah tab yang sudah terbuka untuk membuka tab baru Anda pun bisa membuka link di tab baru. Caranya cukup klik kanan lau pilih "buka tautan di tab baru".

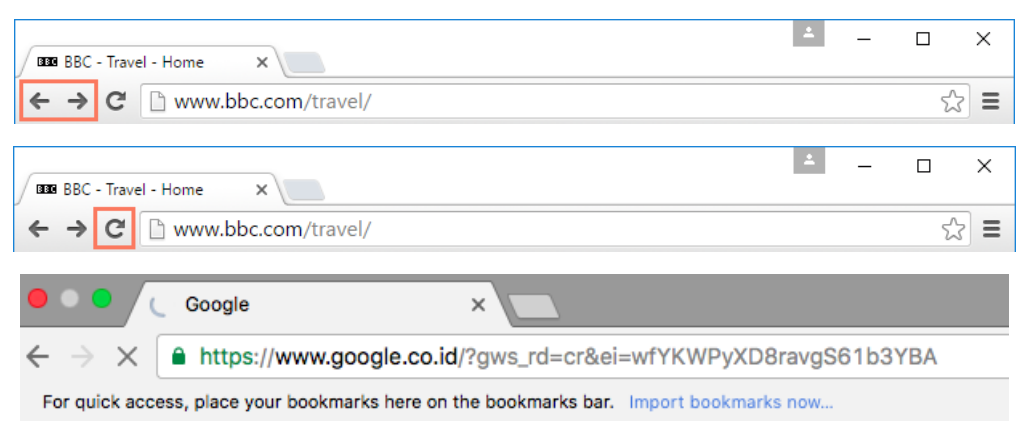




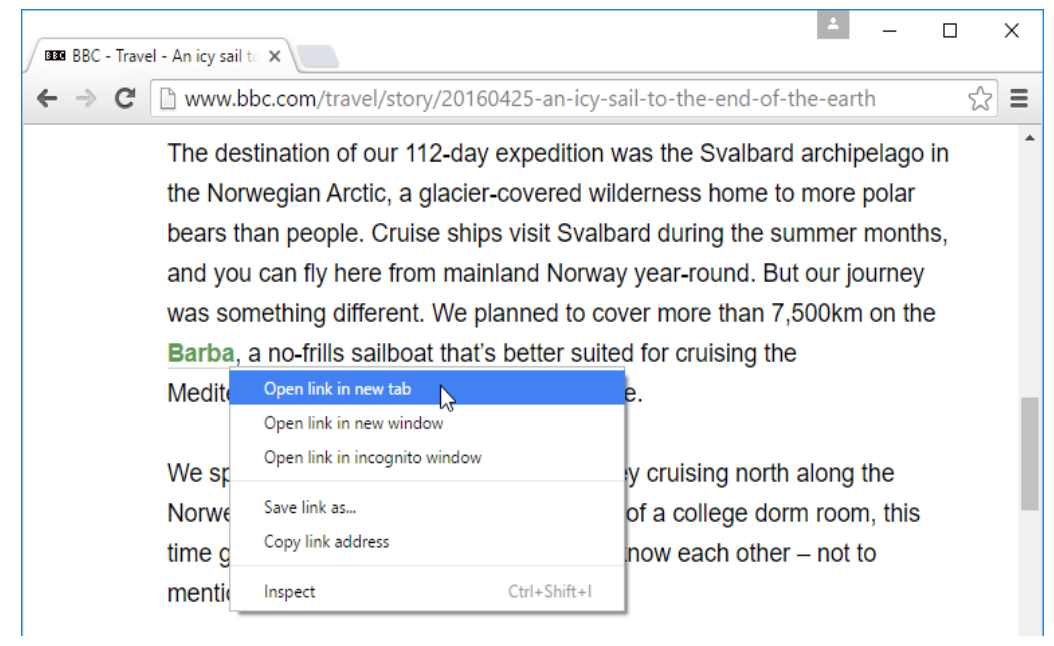

\section{Bookmark \& History}

Terkadang kita sering ingin mengunjungi lagi halaman yang dulu pernah dibuka, tetapi lupa apa alamatnya. Fitur History memungkinkan Anda untuk melihat riwayat dan mencari halaman-halaman yang pernah Anda kunjungi.

Untuk membuka history, klik lambang tiga titik di bagian kanan atas browser, lalu pilih "history".

\begin{tabular}{|c|c|c|c|}
\hline \multicolumn{3}{|c|}{ ahasa Indonesia, e $\times$} & Radix \\
\hline & 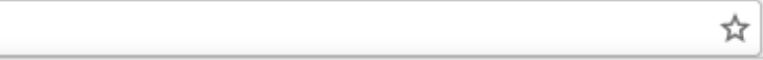 & off $\bigcirc C_{1}^{n}$ & (1) $\vdots$ \\
\hline & \multicolumn{3}{|c|}{ D Awesome Screenshot: Screen capture, Annotate requires new permissions } \\
\hline & \multirow{3}{*}{\multicolumn{2}{|c|}{$\begin{array}{l}\text { New Tab } \\
\text { New Window } \\
\text { New Incognito Window }\end{array}$}} & भT \\
\hline & & & $\mathscr{N}$ \\
\hline$\frac{1}{3} \equiv$. & & & 仓\&N \\
\hline ஆY & \multicolumn{2}{|l|}{ History } & 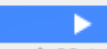 \\
\hline \multirow{3}{*}{ 仓ஆТ } & \multirow{2}{*}{\multicolumn{2}{|c|}{$\begin{array}{l}\text { Downloads } \\
\text { Bookmarks }\end{array}$}} & 仓ஆJ \\
\hline & & & $\triangleright$ \\
\hline & Zoom & \begin{tabular}{|l|l|l|}
- & $100 \%$ & + \\
\end{tabular} & $\pi^{k}$ \\
\hline \multirow[t]{4}{*}{$1 . .}$. & & भP \\
\hline & Cast... & & \\
\hline & \multicolumn{2}{|l|}{ Find... } & ஜF \\
\hline & \multicolumn{2}{|l|}{ More Tools } & $\triangleright$ \\
\hline & Edit & \begin{tabular}{l|l} 
Cut & Copy \\
\end{tabular} & Paste \\
\hline & $\begin{array}{l}\text { Settings } \\
\text { Help }\end{array}$ & & $\triangleright$ \\
\hline
\end{tabular}




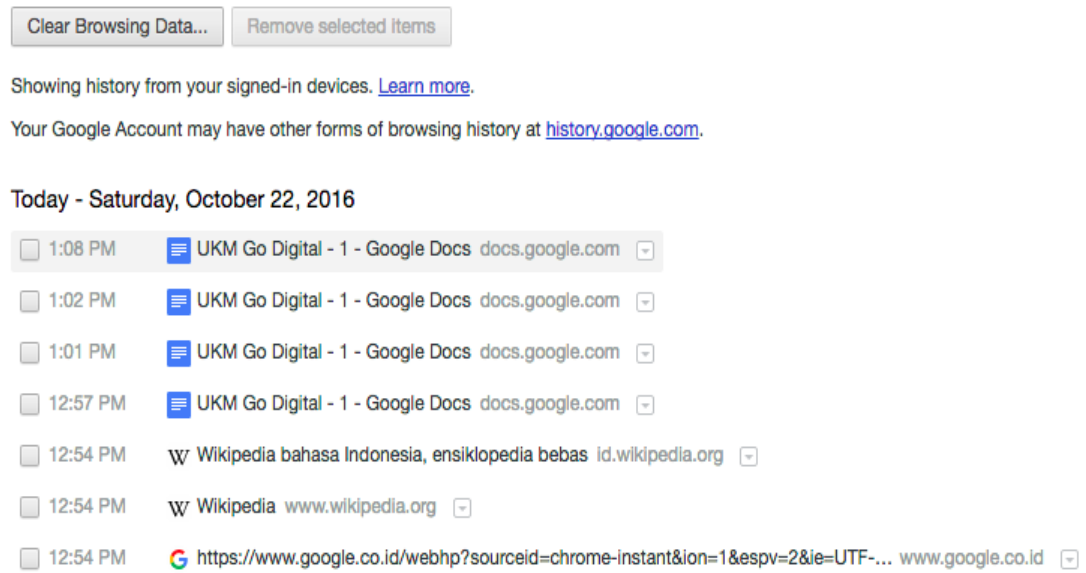

Anda juga mungkin menemukan sebuah situs yang sangat bermanfaat untuk Anda dan ingin Anda kunjungilagi nanti. Fitur bookmark memungkinkan Anda untuk menyimpan alamat situs tersebut.

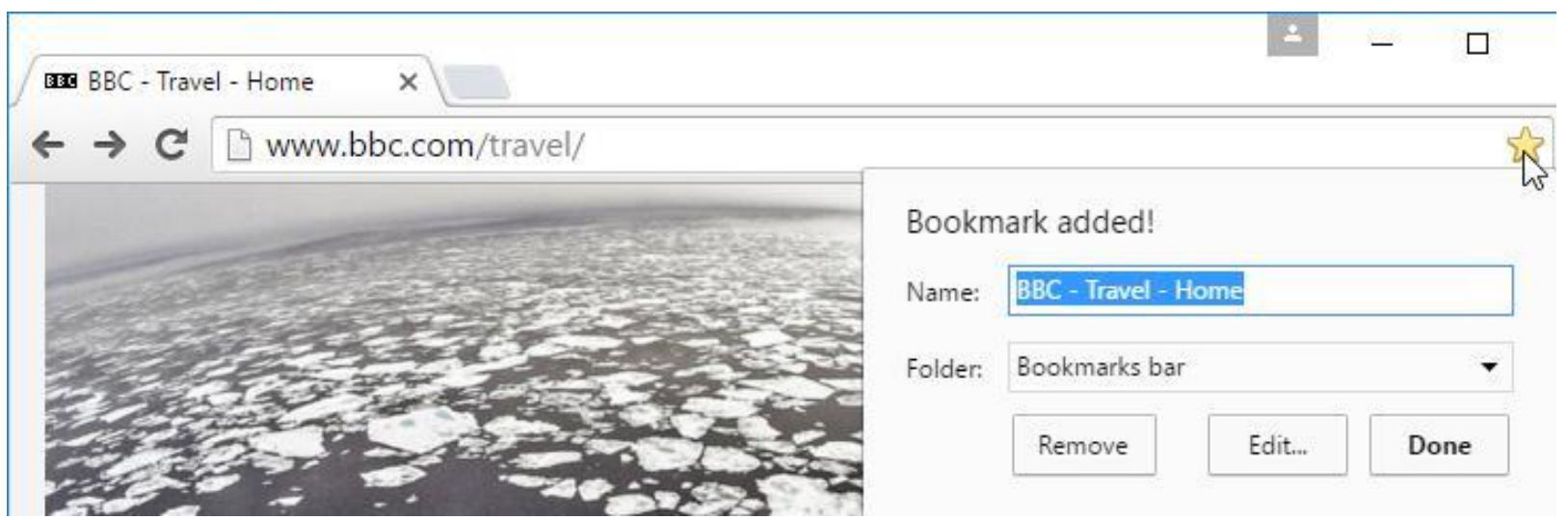

\section{Melakukan Pencarian di Internet}

Terkadang, kita tidak tahu harus ke mana kita di internet. Apa nama situs yang menyediakan peralatan pabrik yang murah? Apa situs yang menyediakan informasi bagaimana cara mendirikan PT di Indonesia? Apa situs yang memberitahu tips dan trik dalam memasarkan produk kita? Tapi tenang saja, karena semua pertanyaan itu dapat dengan mudah bisa terjawab melalui mesin pencarian.

Mesin pencarian (search engine) adalah layanan di internet yang fungsi utamanya adalah mencari apapun di internet: mulai dari alamat kantor dinas pajak, informasi pemasaran produk, hingga di mana membeli peralatan yang bagus dengan cukup mengetik kata kunci yang ingin dicari.

Ada beberapa situs pencarian yang tersedia seperti Yahoo dan Bing, namun yang paling populer adalah 185 Kemendagri - sylabus - 2018 
Google.

6. Untuk memulai pencarian di Google, masukkan "google.com" di browser Anda

7. Masukkan kata kunci yang ingin dicari, seperti "mobil pickup murah" lalu tekan enter untuk menampilkan hasil pencarian

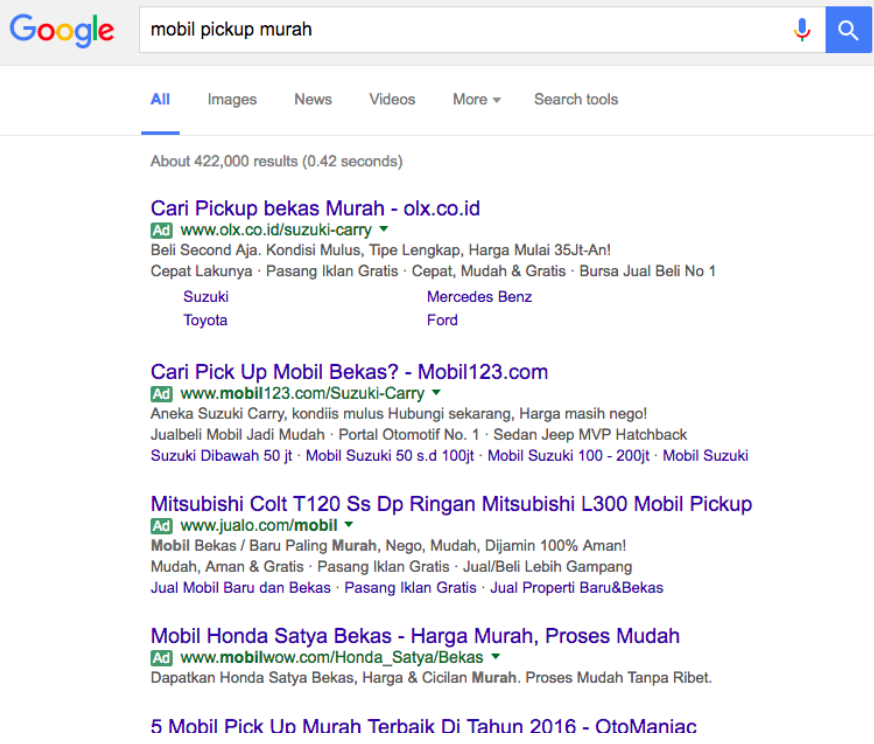

5 Mobil Pick Un Murah Terbaik Di Tahun 2016 - OtoManiac

3. Klik salah satu hasil pencarian

Jika Anda menggunakan Google Chrome, Anda bisa melewati langkah nomor 1 dan langsung mengetikkan kata kunci di kolom alamat di browser Anda.

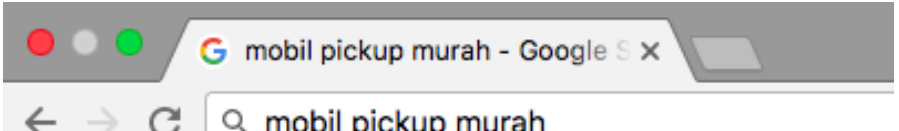

$\leftarrow \rightarrow \mathrm{C}$ Q mobil pickup murah

\section{Mengunduh dari Internet}

Di halaman internet, kita tidak hanya bisa membaca informasi yang disajikan di sana tetapi juga menyimpan gambar ataupun dokumen yang ada di laman tersebut. Proses menyimpan gambar ataupun dokumen dari internet ke komputer kita disebut sebagai downloading atau unduh.

Untuk mengunduh gambar ataupun dokumen, cukup klik kanan di gambar atau dokumen yang hendak disimpan, lalu klik menu "save image as" (untuk gambar) atau "save link as" (untuk dokumen lain). 


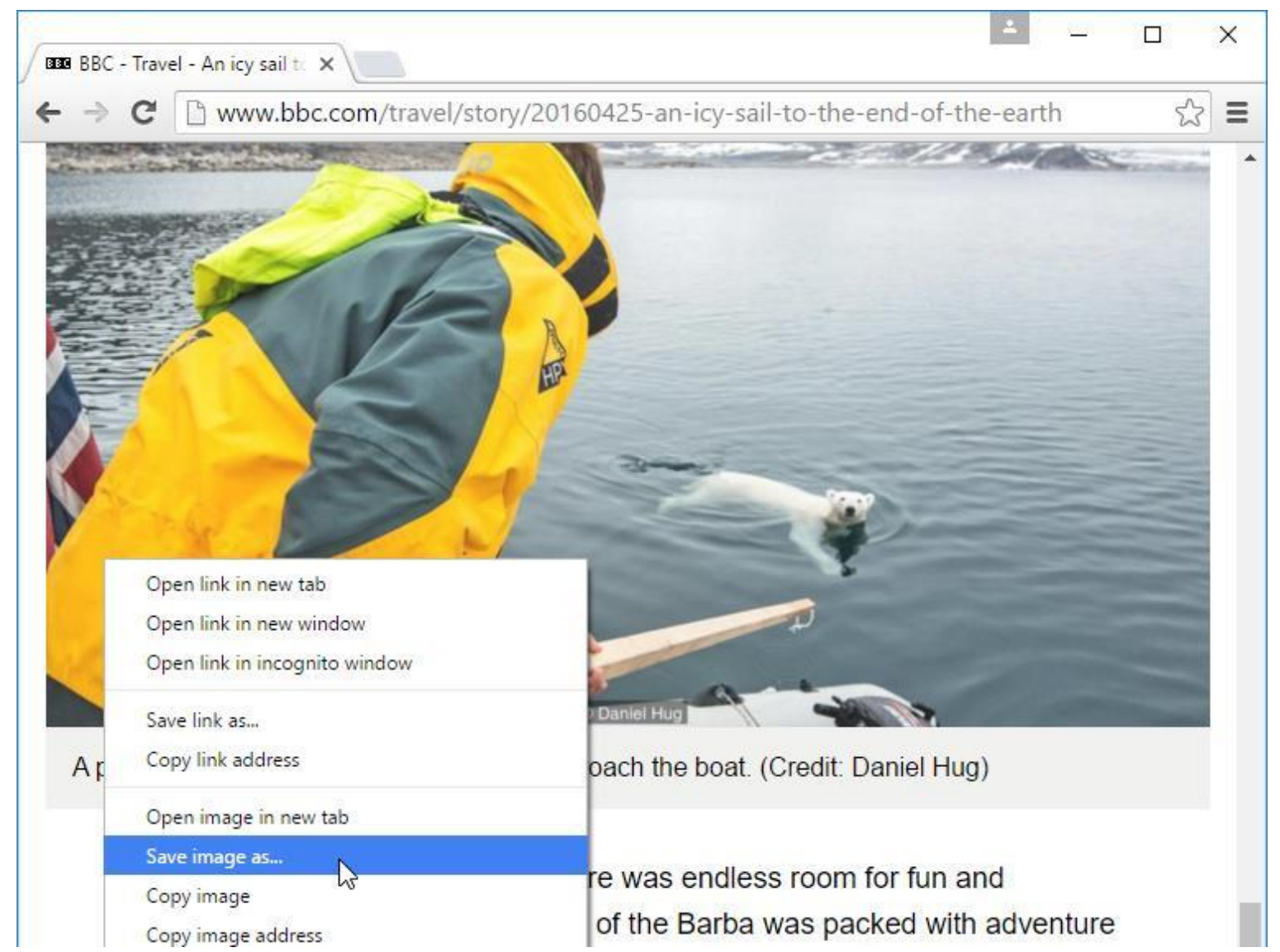

Email adalah kependekan dari electronic mail (surat elektronik) yang merupakan bentuk digital dari surat fisik yang selama ini kita kenal. Berbeda dengan surat fisik, mengirim lewat email gratis karena kita tidak membayar perangko, langsung sampai ke penerima, serta memungkinkan untuk mengirim juga gambar ataupun dokumen.

Saat ini ada banyak layanan surat elektronik / email gratis, yang populer di antaranya adalah Gmail, Outlook Mail, Yahoo Mail.

Untuk modul ini, kami akan menjelaskan bagaimana caranya membuat alamat email di Gmail. Gmail adalah layanan email gratis yang disediakan oleh Google, dengan kapasitas surat masuk (inbox) sebesar $15 \mathrm{~GB}$. 


\section{Membuat Alamat Email}

\section{Create your Google Account}

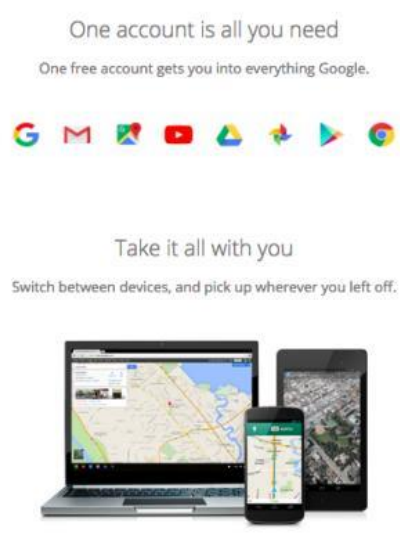

(5) Dengan menggunakan peramban (browser) Anda, masukkan alamat berikut: https://accounts.google.com/SignUp

(6) Isilah formulir pendaftaran dengan data diri Anda. Ada baiknya Anda menggunakan nama perusahaan (seperti "Agricandra Persada") daripada nama pribadi.

Patut diingat: alamat email adalah perwakilan perusahaan Anda, jadi hindari memakai nama yang terkesan 'alay' seperti “cong.qeren@gmail.com”, dan cukup gunakan nama perusahaan Anda (contoh: agricandra.persada@gmail.com) sebagai alamat email.

(4) Untuk password, jangan gunakan password yang gampang ditebak, seperti "qwerty", "123456", ataupun tanggal lahir Anda. Gunakan password yang hanya Anda ataupun orang dalam perusahaan Anda tahu. Sangat disarankan untuk menggunakan simbol untuk memperkuat password Anda, dengan contoh: jika password Anda adalah "mekarsari", maka disarankan untuk memperkuatnya menjadi “M3k@rsaR!”. Gantilah password setiap 3 bulan sekali. Jangan gunakan password yang sama untuk layanan yang berbeda.

(5) Jika formulir sudah diisi dan alamat email belum terpakai, setujui ketentuan layanan, dan selamat, Anda sudah memiliki email! 


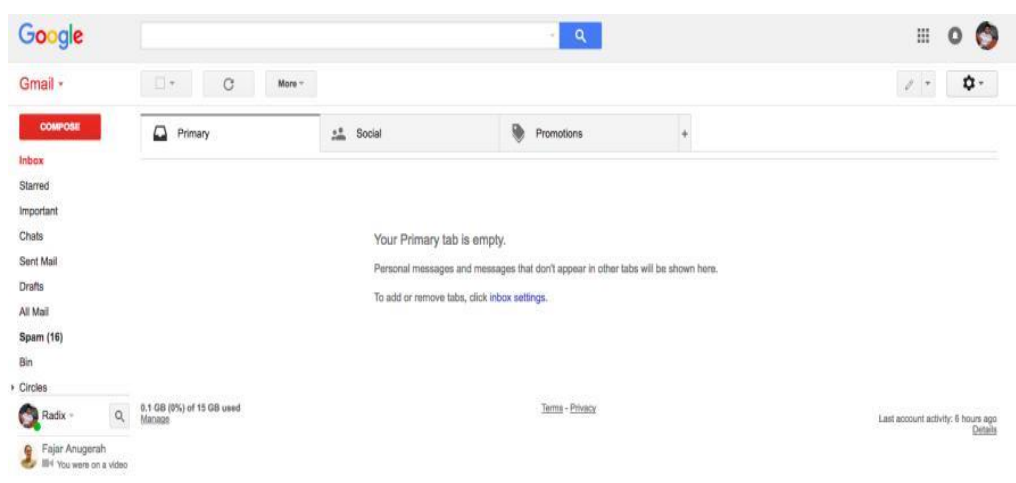

\section{Email vs BBM / WhatsApp}

Email yang baru Anda buat dapat digunakan untuk menghubungi relasi bisnis, mengirimkan proposal, penawaran harga, dan banyak lagi. Berbeda dengan layanan chatting seperti WhatsApp ataupun BBM, semua pembicaraan melalui email akan disimpan dengan baik dan bisa dicari, sehingga jika Anda ingin mencari lagi pembicaraan yang dulu pernah terjadi, Anda bisa mencarinya dalam sekejap.

Maka sangat disarankan bagi Anda untuk menggunakan email dalam pembicaraan bisnis yang bersifat penting dibandingkan hanya melalui WhatsApp ataupun BBM.

\section{Mengirim Email}

Ikuti panduan berikut untuk mengirimkan email.

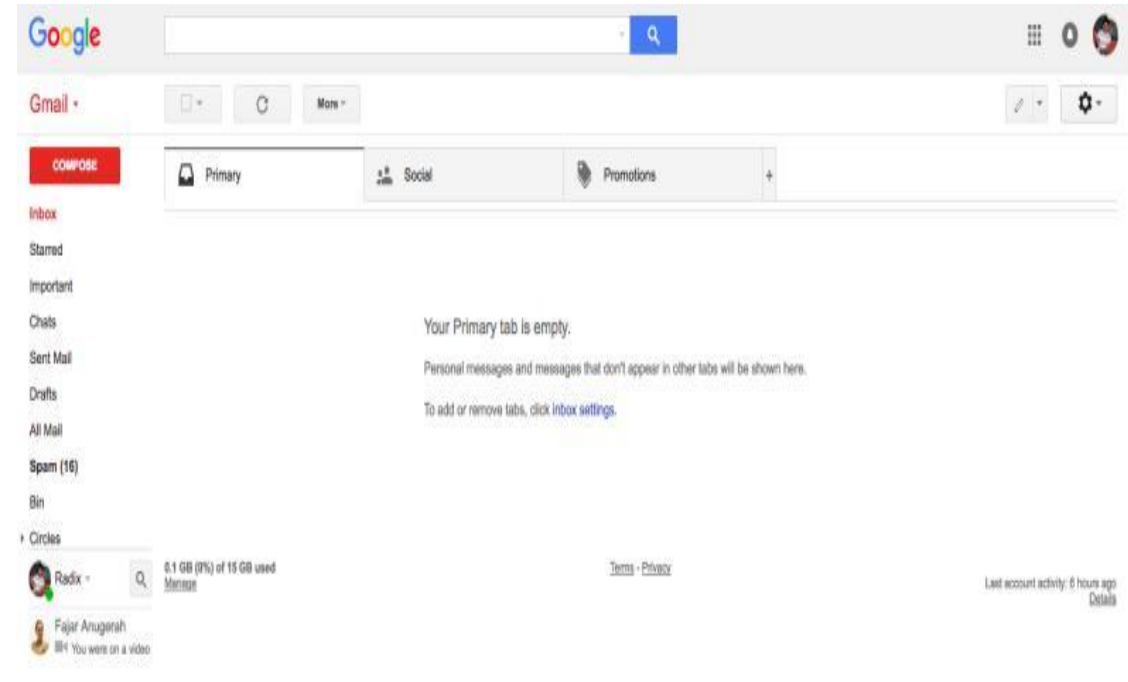


1. Klik tombol merah di pojok kanan atas, lalu akan terbuka menu untuk membuat surat baru.

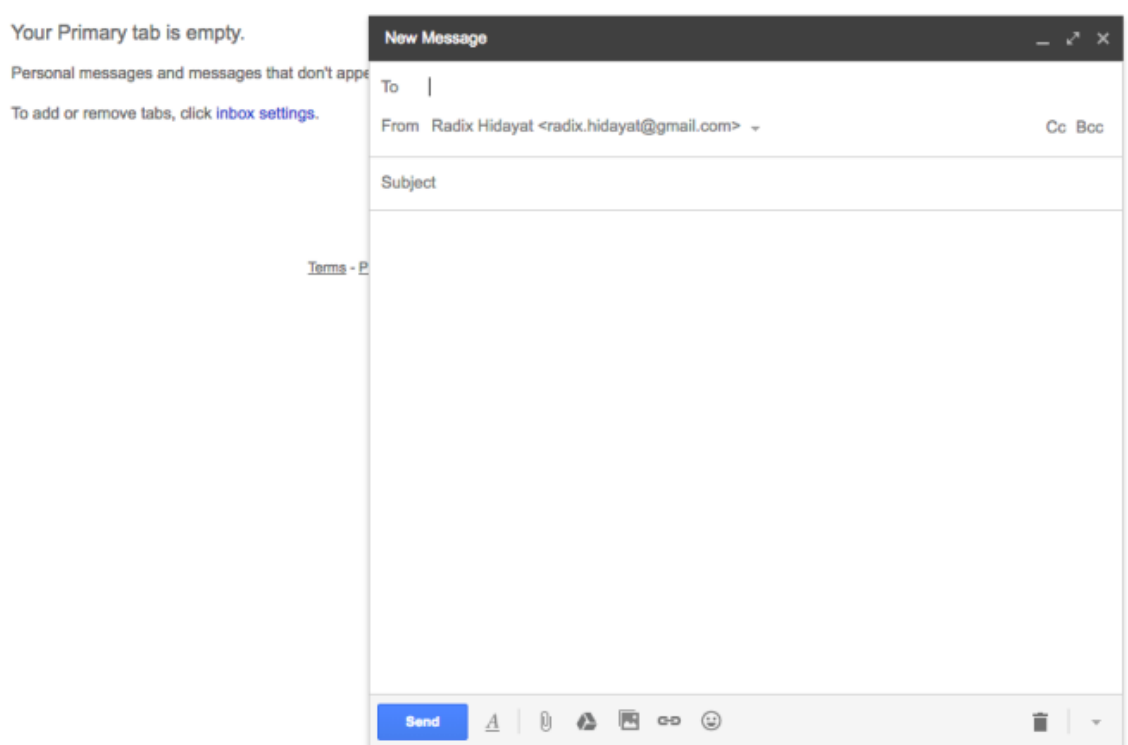

2. Cobalah mengirimkan email pada diri Anda sendiri! Masukkan alamat email Anda sendiri di kolom penerima, masukkan judul, dan juga isi email.

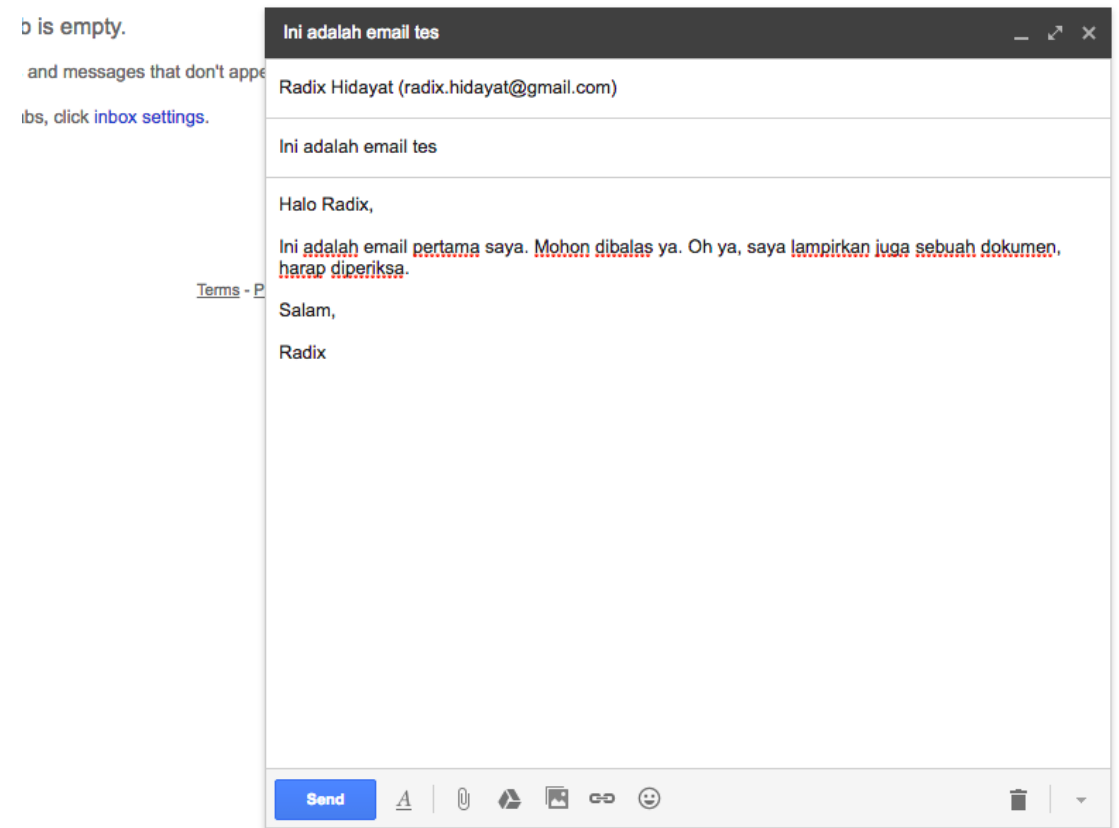

Harap diingat: mengirim email pada prinsipnya sama saja dengan mengirim surat resmi, dan berbeda dengan mengirim pesan singkat maupun WhatsApp dan BBM. Oleh karena itu, kaidah penulisan surat 
haruslah diperhatikan, seperti:

5. Salam ("Selamat pagi", "Dengan hormat", dsb),

6. Pembuka ("Perkenalkan nama saya Aslam dari CV Agricandra Persada"),

7. Isi ("maksud dari email ini adalah untuk menawarkan produk kami yang berupa...."),

d. Penutup ("Terima kasih atas perhatian Anda")

3. Anda bisa juga melampirkan gambar ataupun dokumen ke dalam email Anda. Ini sangatlah berguna jika Anda ingin mengirimkan proposal kerja sama ataupun penawaran harga. Untuk melampirkan gambar ataupun dokumen, klik gambar klip di bagian bawah, lalu pilihlah gambar atau dokumen di komputer Anda yang ingin dilampirkan.

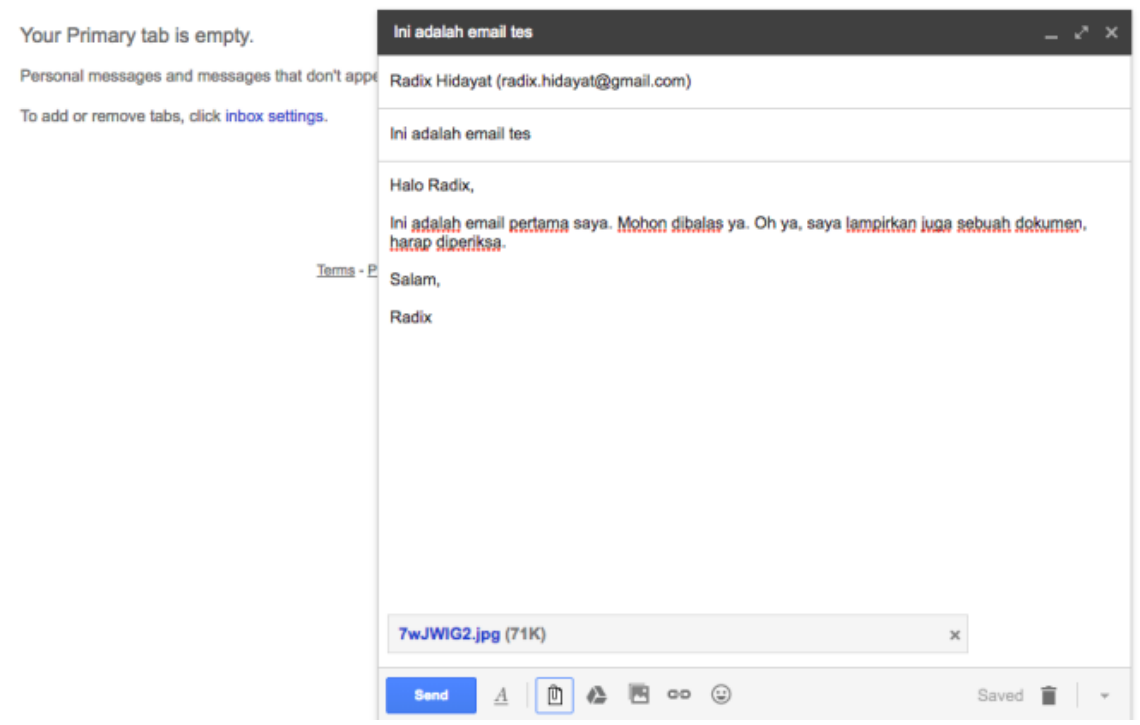

4. Periksalah kembali isi surat yang hendak Anda kirim, pastikan tidak ada kesalahan pada penulisan. Kalau Anda sudah yakin, klik tombol biru untuk mengirimkan email Anda.

\section{Menerima dan Membalas Email}

Email yang Anda terima akan muncul di bagian depan ataupun di menu Kotak Masuk. Email yang belum terbaca akan tercetak tebal. 


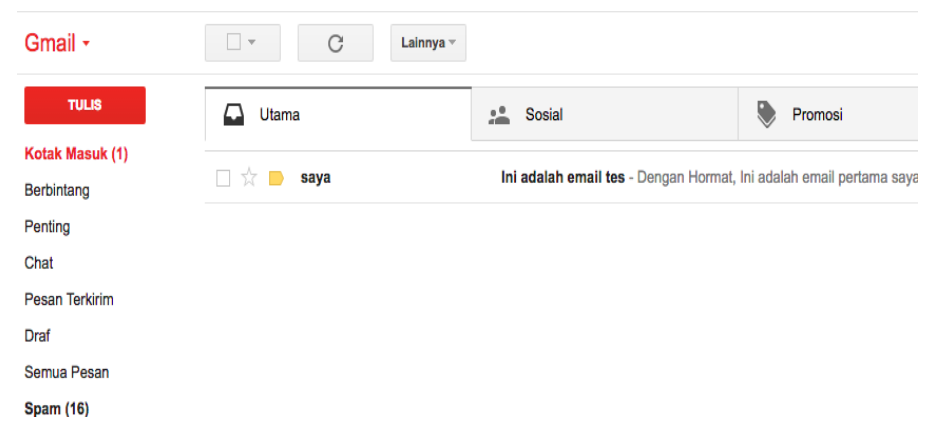

Kliklah email yang baru saja Anda kirim ke diri Anda sendiri dan email itu akan terbuka.

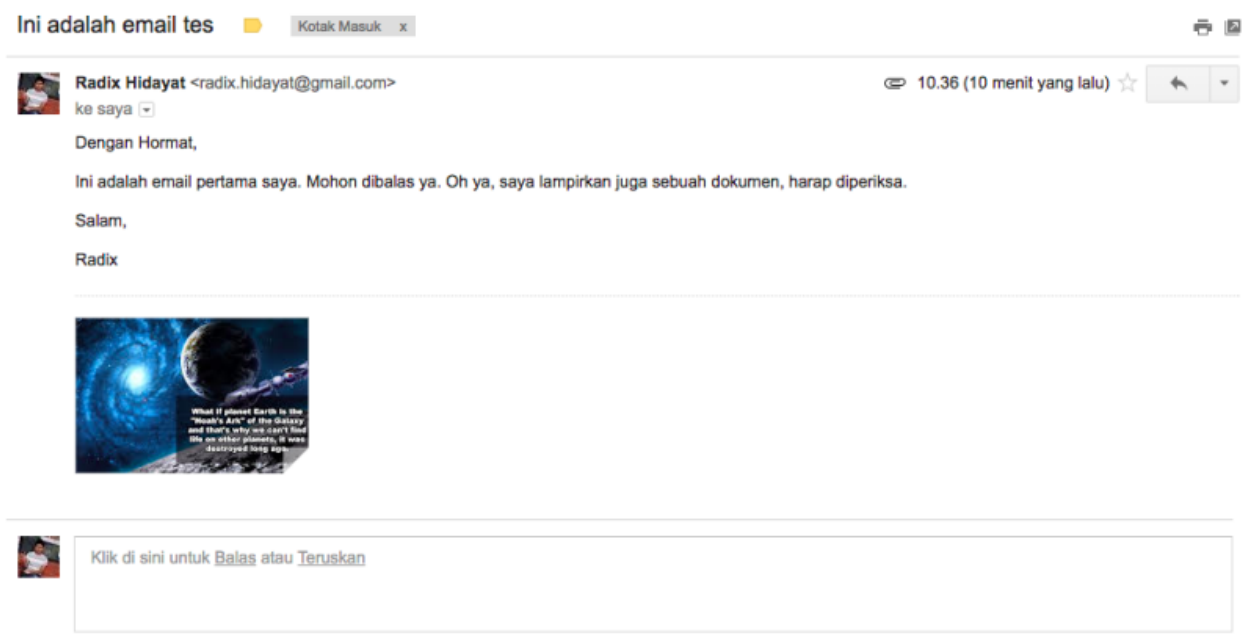

Untuk membalas email yang masuk, klik tombol panah berbelok yang ada di pojok kanan atas ataupun klik di kolom kosong di bawah email

tersebut. Seperti halnya di membuat email baru, Anda bisa melampirkan juga gambar ataupun dokumen ke email balasan.

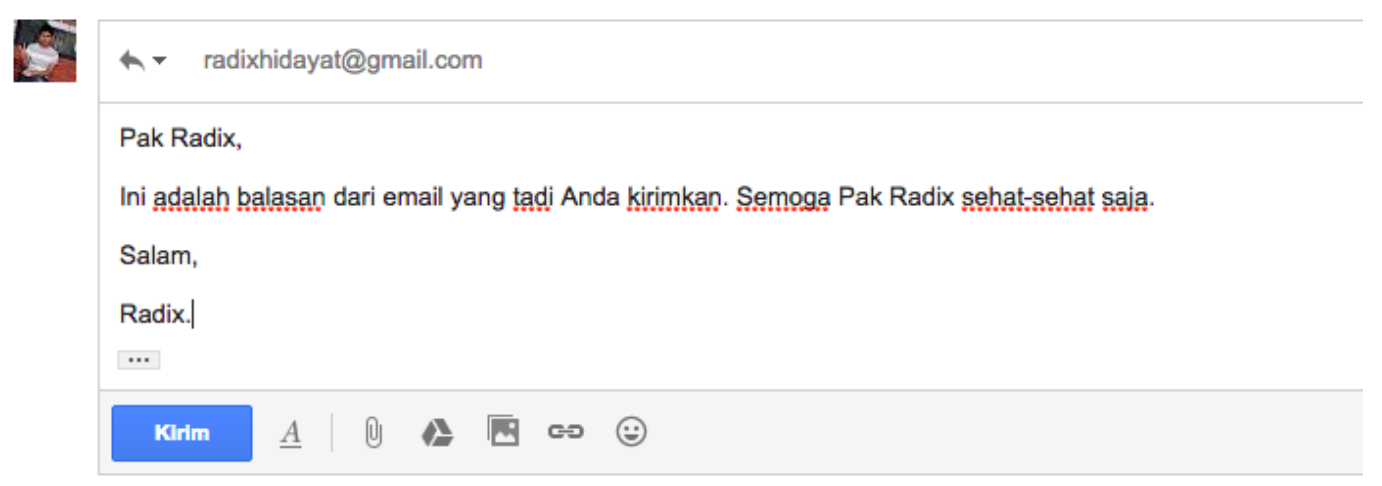

Seperti biasa, periksalah kembali email balasan sebelum dikirim untuk memastikan bahwa isinya 
sesuai dan tidak ada kesalahan penulisan. Kalau Anda sudah yakin, kliklah tombol "Kirim" dan email balasan akan terkirim.

\section{Mencari Email}

Salah satu keunggulan email dibandingkan WhatsApp atau BBM adalah penyimpanan email. Anda bisa dengan mudah mencari email yang Anda kirim ataupun terima dalam sekejap, yang sangat memudahkan jika Anda membutuhkan referensi dari email-email lama Anda.

Untuk mencari email lama, cukup ketikkan kata kunci di kolom pencarian lalu tekan tombol enter, dan email yang sesuai dengan kata kunci akan muncul.

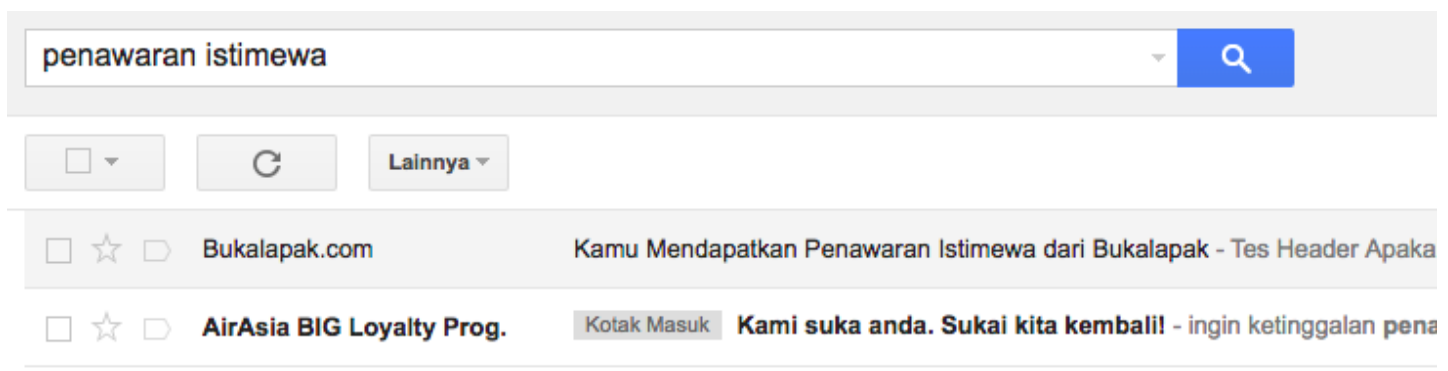

\section{Signature}

Signature adalah tanda tangan yang telah anda tentukan sebelumnya dan otomatis akan muncul di bawah email yang Anda tulis. Signature amat berguna karena Anda bisa menuliskan nama, alamat, nomor HP, maupun situs perusahaan Anda pada setiap email yang Anda kirim secara otomatis.

Adapun cara mengaktifkan signature adalah: 1 . Klik lambang roda gigi di bagian kanan atas, lalu klik pilihan "Setelan"

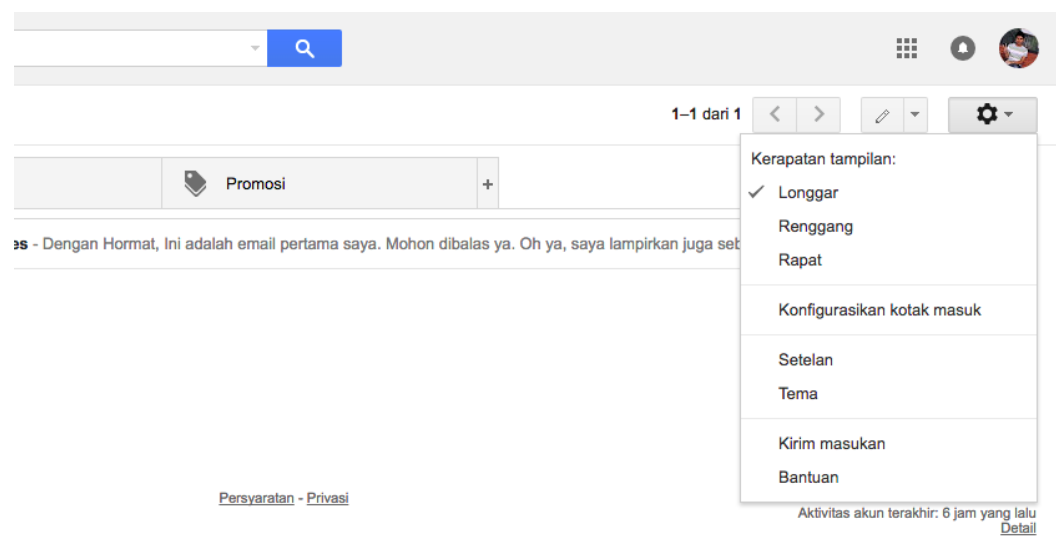

2. Di bagian bawah menu setelah, Anda akan menemukan bagian "tanda tangan". Masukkanlah 
informasi yang memudahkan orang untuk mencari kontak Anda, seperti: nama, alamat, telepon, situs, dsb.

3. Klik "Simpan Perubahan".

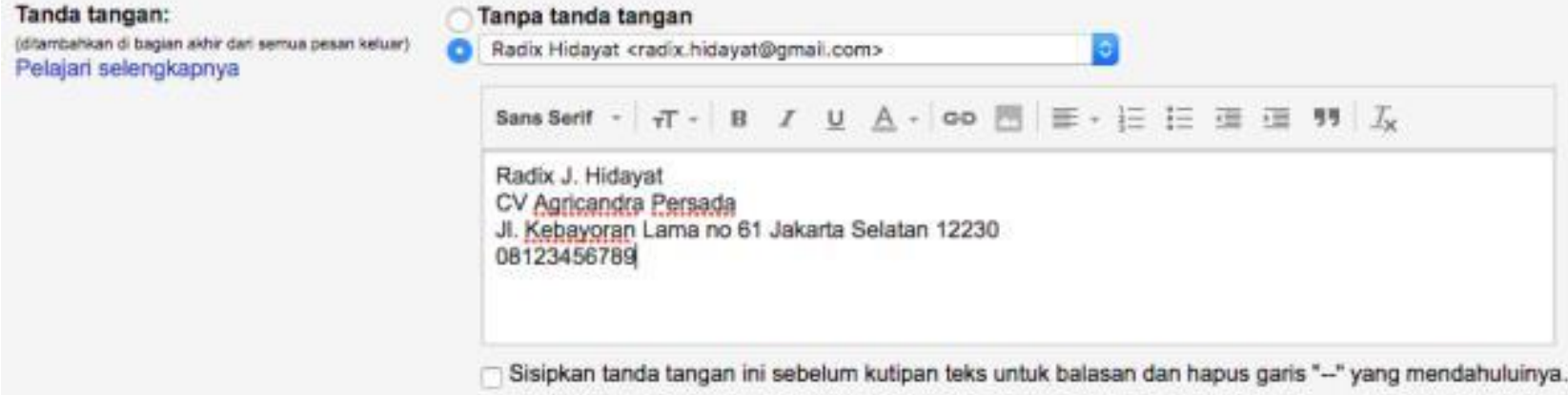


Modul 1

22.Laporan Keuangan Lanjutan Penjelasan Umum Modul

22. Laporan Keuangan Lanjutan

\subsubsection{Rekap Modul Sebelumnya: Laporan Keuangan Sederhana}

\subsubsection{Perbedaan tentang arus kas dan laba rugi}

\subsubsection{Kebutuhan permodalan dan jenis sumber dana}

Output:

1. Peserta paham perbedaan arus kas dan laba rugi, beserta kegunaan masing-masing laporan

2. Peserta paham jenis permodalan seperti apa yang dibutuhkan untuk bisnisnya Estimasi durasi untuk mengerjakan secara mandiri: 1-3 jam Dukungan yang dibutuhkan:

o Pendampingan Mentor untuk membahas perbedaan laporan keuangan

o Pendampingan untuk menggunakan aplikasi AkuntingMudah Lembar Kerja Modul Laporan Keuangan Lanjutan

Sebelum kita mulai, mari mengingat kembali apa yang sudah dipelajari dalam modul dasar "Laporan Keuangan Sederhana":

1. Membaca Laporan Laba Rugi

a. Apakah Anda sudah dapat mengambil langkah lanjutan setelah membaca laporan keuangan bisnis Anda?

2. Masukkan semua transaksi dari Buku Kas ke aplikasi Akunting Mudah

a. Apakah Anda sudah memiliki laporan keuangan yang dihasilkan oleh aplikasi Akunting Mudah?

Jika Anda belum melakukan kedua hal di atas, Anda belum siap untuk mempelajari modul ini. Ingat, PRAKTEK LEBIH PENTING DARI SEKEDAR BELAJAR!

\section{A. Perbedaan Arus Kas \& Laba Rugi}

Dalam beberapa hal, tidak ada perbedaan antara kedua laporan ini. Tetapi ada kalanya bisa terjadi beberapa transaksi yang membutuhkan pencatatan yang berbeda, yaitu:

- Pengeluaran biaya atau pendapatan diterima di depan 
o Contoh:

membayar biaya sewa tempat Rp. 12 juta untuk 1 tahun di muka di bulan April 2015.

Dalam hal ini, biaya yang tercatat dalam laporan laba rugi adalah Rp. 1 juta per bulan untuk bulan April 2015 s/d Maret 2016. Namun dalam arus kas sudah terlihat uang keluar sejumlah Rp. 12 juta di bulan April 2015

o Contoh:

menerima pembayaran uang muka sebesar $25 \%$ walaupun barang belum diserahkan. Untuk barang senilai Rp. 10 juta yang dijadwalkan diserahkan bulan Desember, kita sudah menerima Rp. 2,5 juta sebagai DP pada bulan Oktober

Dalam hal ini, laporan laba rugi bulan Oktober belum mencatat pendapatan, tetapi sudah dicatat dalam Laporan Arus Kas. Pendapatan baru dicatat di bulan Desember setelah penyerahan barang

- Pengeluaran biaya atau pendapatan diterima di belakang

o Contoh:

barang sudah diterima dari supplier senilai Rp. 10 juta di bulan September tetapi kita baru akan membayar supplier dengan tempo 3 bulan di belakang (bulan Desember)

Dalam hal ini, laporan laba rugi bulan September sudah mencatat ada pengeluaran Rp. 10 juta walaupun laporan arus kas baru akan mencatat pengeluaran di bulan Desember waktu pembayaran (menjadi hutang pada bulan Oktober)

o Contoh: barang sudah diserahkan kepada pembeli senilai Rp. 10 juta pada bulan Oktober, walaupun pembayaran baru akan diterima pada bulan Desember

Dalam hal ini, laporan laba rugi bulan Oktober sudah mencatat pendapatan Rp. 10 juta, tetapi sebagai piutang

\section{B. Jenis Permodalan Yang Tepat}

Seringkali terjadi, laporan laba rugi menunjukkan keuntungan, tetapi bisnis kekurangan dana. Hal ini biasa terjadi, dan biasanya bisa diatasi dengan permodalan melalui pinjaman ataupun investasi

Pada saat mempertimbangkan untuk mendapatkan tambahan modal melalui, Anda perlu mempertimbangkan 2 hal:

1. Kapan dana harus dikembalikan

196 Kemendagri - sylabus - 2018 


\section{Bagaimana pembayaran cicilan}

Kedua hal ini akan bergantung kepada bagaimana Anda akan menggunakan dana tersebut. Kebutuhan pemakaian yang berbeda akan menentukan skema pinjaman yang berbeda, misalnya:

Anda dibayar mundur 3 bulan untuk barang yang sudah diserahkan kepada pembeli. Maka kebutuhan pinjaman adalah hanya untuk 3 bulan. Tidak perlu mengambil pinjaman selama 1 tahun jika kebutuhan lebih pendek

Anda membutuhkan dana untuk membeli mesin produksi yang baru. Mesin ini bisa dipakai untuk jangka waktu yang lama, mungkin 10 tahun. Maka Anda bisa memilih untuk mencicil pinjaman ini untuk 3 tahun atau bahkan lebih supaya beban cicilan lebih murah.

Setelah Anda memiliki laporan yang lengkap, saat ini waktu yang tepat untuk Anda memutuskan bantuan permodalan seperti apa yang Anda butuhkan. Jangan mengambil pinjaman yang tidak terlalu Anda butuhkan ataupun yang tidak sesuai dengan kebutuhan dan arus kas Anda.

\section{Memperoleh Modal Sesuai Kebutuhan}

Ketika Anda sudah dapat mengidentifikasikan modal seperti apa yang Anda perlukan, lalu Anda menghitung dengan tepat berapa kebutuhan modal yang Anda perlukan, maka Anda tinggal satu langkah lagi untuk dapat memperoleh modal, yaitu Anda tinggal datang ke pemodal (perbankan maupun non perbankan). Agar waktu Anda tidak terbuang banyak, maka Anda harus memilih lembaga penyedia modal yang sesuai dengan kebutuhan Anda sehingga Anda tidak perlu ditolak.

\section{Ke Mana Seharusnya Anda Mencari Modal?}

\section{Kebutuhan modal sampai dengan 10 juta}

Jika Anda hanya membutuhkan modal kurang dari Rp. 5.000.000,00, maka Anda tidak perlu membuat atau menyusun proposal yang sangat canggih.Apabila Anda memiliki kelompok dalam berbisnis, Anda dapat mengajukan pembiayaan kepada Lembaga Keuangan Mikro (LKM) yang memberikan fasilitas pinjaman tanggung renteng. Cara yang lain adalah Anda membuat kelompok kemudian mengajukan dana CSR dari perusahaan besar yang ada di sekitar Anda. Dengan demikian Anda tidak perlu menyediakan jaminan sendiri untuk 
mencari pinjaman. Apabila Anda tidak memiliki jaminan, tetapi Anda punya orang yang dapat memberikan referensi atau bahkan menjadi avalist (orang yang bersedia menjamin pinjaman Anda), maka Anda dapat mendatangi kantor BUMN di sekitar Anda untuk mengajukan dana program kemitraan (PK).

Lain halnya apabila Anda memiliki jaminan, seperti BPKB Sepeda Motor, "girik tanah" dan SPPT-nya, atau jaminan lain yang masih bisa diterima, maka Anda dapat datang ke BPR, atau ke lembaga pembiayaan ataupun bank yang menyediakan layanan kredit mikro, dan sebagainya.

Di lain pihak, Anda juga dapat mendatangi kantor Pegadaian untuk mengajukan pinjaman, hanya saja apabila Anda datang ke kantor Pegadaian Anda harus membawa barang yang akan di jaminkan (digadai, disimpan di kantor Pegadaian), seperti perhiasan, perkakas rumah tangga, barang elektronik, dan sebagainya.

Prosedur pengajuan antara lembaga satu dengan lainnya biasanya berbeda-beda, namun pada umumnya menggunakan prosedur yang sangat sederhana.Biasanya Anda cukup datang mengisi formulir dengan menyertai identitas diri Anda.

\section{Kebutuhan modal sampai dengan 50 juta}

Lembaga penyedia modal untuk pinjaman yang besarnya sampai dengan Rp. $50.000 .000,00$ pada umumnya masih mirip dengan penyedia permodalan yang besarnya sampai dengan 10 juta.Pinjaman segmen ini yang berasal dari danaPK-BUMN ataupun CSR biasanya sudah sangat selektif dan biasanya bersifat khusus.

Dan yang cukup baru adalah kesempatan untuk mendapatkan pembiayaan dari LPDB (Lembaga Pengelolaan Dana Bergulir), sebuah lembaga pemerintah yang bernaung dibawah Kementrian Koperasi dan UKM ini memiliki kapasitas untuk memberikan permodalan kepada usaha kecil sampai Rp 50 juta.

Di beberapa daerah dominasi lembaga-lembaga permodalan komersial juga ditandai dengan masuknya lembaga modal ventura, dan juga BPR, serta pinjaman tanpa agunan dari Bank daerah atau nasional.

Untuk mengakses lembaga-lembaga permodalan komersial seperti di atas pada umumnya Anda dituntut untuk menyediakan jaminan yang bersifat marketable (mudah dijual untuk melunasi pinjaman Anda, apabila kredit atau pembiayaan Anda macet). 


\section{Kebutuhan modal sampai dengan 500 juta}

Segmen ini pada umumnya didominasi oleh lembaga- lembaga khususnya Bank yang bersifat komersial. Kalaupun dalam segmen ini terdapat pinjaman bersubsidi dengan sumber danaProgram Kemitraan BUMN,yang bersifat sangat khusus.Demikan pula LPDB bisa menjadi tempat untuk kita mendapatkan permodalan dalam bentuk pinjaman di segmen ini.

Perlu diingat, jika Anda membutuhkan pinjaman sampai sebesar Rp. 500.000.00,00 maka biasanya Anda mutlak dimintai jaminan.Dimana jenis jaminan yang dipersyaratkan pun sekedar marketable, tetapi harus mempunyai riwayat hukum yang jelas. Proses penilaian kelayakan bisnis Anda pun mulai ketat, beberapa analisis sensitivitas dilakukan secara bertahap.

\section{PENGERTIAN PAJAK PERTAMBAHAN NILAI (PPN)}

PPN atau Pajak Pertambahan Nilai merupakan jenis pajak tidak langsung untuk disetor oleh pihak lain (pedagang) yang bukan merupakan penanggung pajak(konsumen akhir). Prinsip dasarnya adalah suatu pajak yang harus dikenakan pada setiap proses produksi dan distribusi, tetapi jumlah pajak yang terutang dibebankan kepada konsumen akhir yang memakai produk tersebut.

\section{Langkah Mudah Buat SPT PPN di OnlinePajak}

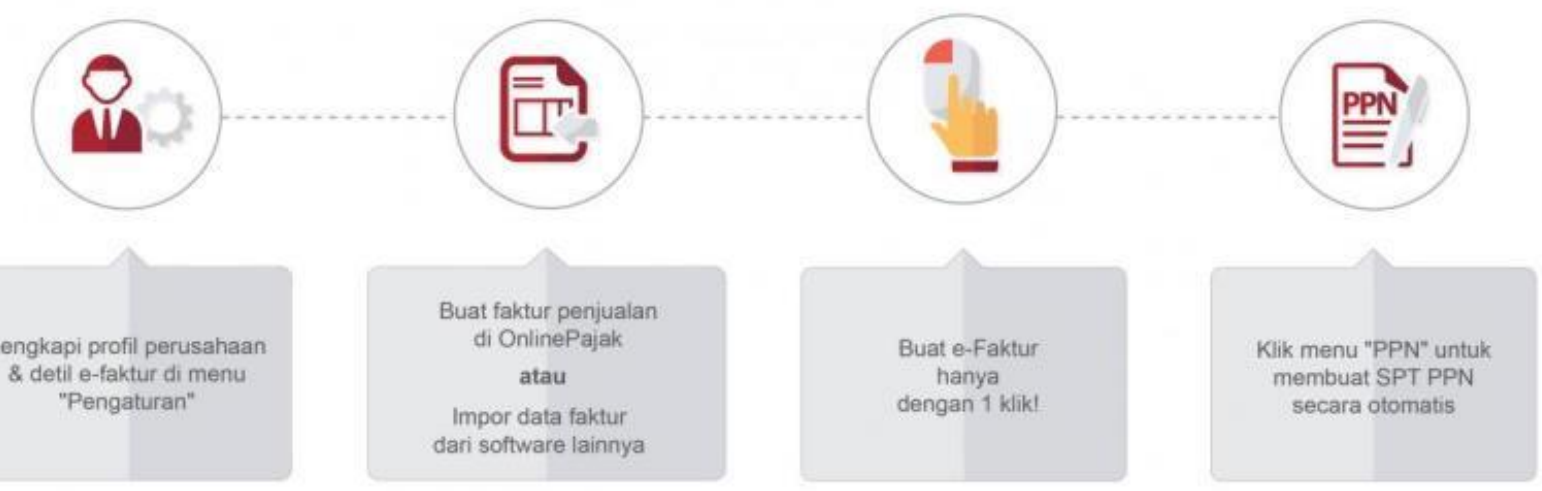




\section{OBJEK PPN (PAJAK PERTAMBAHAN NILAI)}

Pajak Pertambahan Nilai (PPN) dikenakan pada :

Penyerahan Barang Kena Pajak (BPK) dan Jasa Kena Pajak (JKP) di dalam Daerah Pabean yang dilakukan oleh pengusaha
a. Impor Barang Kena Pajak
b. Pemanfaatan Barang Kena Pajak tidak berwujud dari luar Daerah Pabean di dalam Daerah Pabean
c. Pemanfaatan Jasa Kena Pajak dari luar Daerah Pabean di dalam Daerah Pabean

d. Ekspor Barang Kena Pajak berwujud atau tidak berwujud dan Ekspor Jasa Kena Pajak oleh Pengusaha Kena Pajak (PKP)

\section{KINI BUAT E-FAKTUR DAN SPT MASA PPN HANYA 1 KLIK DAN TANPA BIAYA?}

Gunakan OnlinePajak, Aplikasi pajak online yang mempermudah dan menghemat waktu Anda secara signifikan! Hitung, setor dan lapor SPT Masa PPN, semua dilakukan secara online dalam satu aplikasi terpadu!

\section{Mengapa Perlu Buat e-Faktur \& SPT PPN di OnlinePajak?}
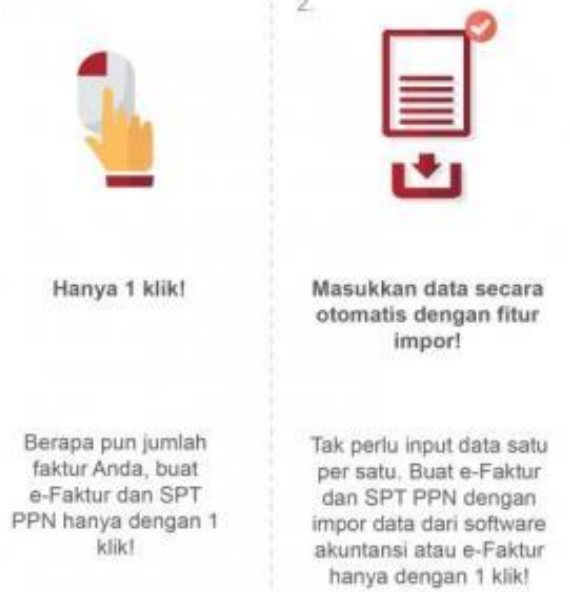

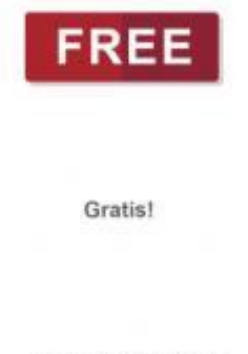

Berapa pun jumlah e-faktur yang Anda buat dan impor tetap gratis selamanya!

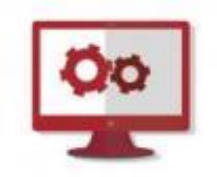

Terintegrasi dengan sistem e-billing, pembayaran online dan e-filing gratis!

Hitung, setor dan lapor PPN Anda dalam 1 aplikasi terpadu secara online dan gratis!

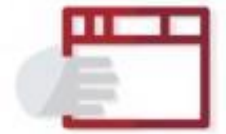

Terhubung dengan sistem layanan pengiriman, penagihan dan notifikasi faktur terpadu.

Tak perlu repot mengirim dan menagih faktur lagil Sistem kami dapat melakukannya secara otomatis untuk Anda dan segera menginformasikan ketika faktur sudah dikirim dan dibayarkan. 


\section{TARIF PPN (PAJAK PERTAMBAHAN NILAI)}

Tarif PPN menurut ketentuan Undang-Undang Dasar No.42 tahun 2009 pasal 7 :

1. Tarif PPN (Pajak Pertambahan Nilai) adalah $10 \%$ (sepuluh persen).

2. Tarif PPN (Pajak Pertambahan Nilai) sebesar $0 \%$ (nol persen) diterapkan atas:

A. Ekspor Barang Kena Pajak Berwujud

B. Ekspor Barang Kena Pajak Tidak Berwujud

C. EksporJasaKenaPajak

3. Tarif pajak sebagaimana dimaksud pada ayat (1) dapat berubah menjadi paling rendah 5\% (lima persen) dan paling tinggi sebesar 15\% (lima belas persen) sebagaimana diatur oleh Peraturan Pemerintah.

\section{PENGUSAHA KENA PAJAK SEBAGAI PIHAK YANG MENYETOR DAN MELAPORKAN PPN}

Pengusaha Kena Pajak (PKP) adalah pihak yang wajib menyetor dan melaporkan PPN.

Setiap tanggal di akhir bulan adalah batas akhir waktu penyetoran dan pelaporan PPN oleh PKP.

Sesuai dengan ketentuan PMK No.197/PMK.03/2013, suatu perusahaan atau seorang pengusaha ditetapkan sebagai PKP bila transaksi penjualannya melampaui jumlah Rp 4,8 miliar dalam setahun. Jika pengusaha tidak dapat mencapai transaksi dengan jumlah Rp 4,8 miliar tersebut, maka pengusaha dapat langsung mencabut permohonan pengukuhan sebagai PKP. Dengan menjadi PKP, pengusaha wajib memungut, menyetor dan melaporkan PPN yang terutang. Dalam perhitungan PPN yang wajib disetor oleh PKP, ada yang disebut dengan pajak keluaran dan pajak masukan.Pajak keluaran ialah PPN yang dipungut ketika PKP menjual produknya. Sedangkan, pajak masukan ialah PPN yang dibayar ketika PKP membeli, memperoleh maupun membuat produknya.

Di OnlinePajak, Anda dapat membuat e-faktur, ID billing, setor pajak online dan e-filing SPT Masa PPN secara mudah, hanya dalam 1 klik dan gratis!

\section{KESIMPULAN}

PPN atau Pajak Pertambahan Nilai adalah jenis

pajak yang disetor dan dilaporkan pihak penjual yang telah dikukuhkan sebagai Pengusaha Kena Pajak (PKP).

1. Batas waktu penyetoran dan pelaporan PPN adalah setiap akhir bulan.

2. Sejak tanggal 1 Juli 2016, PKP se-Indonesia wajib membuat e-Faktur atau faktur pajak elektronik sebagai prasyarat pelaporan SPT Masa PPN. 
3. Pajak keluaran adalah PPN yang dipungut ketika PKP menjual produknya.

4. Pajak masukan ialah PPN yang dibayar ketika PKP membeli, memperoleh maupun membuat produknya.

OnlinePajak, PKP dapat membuat e-faktur, SPT Masa PPN, buat ID billing, setor online dan efiling PPN dalam satu aplikasi terpadu dan hanya membutuhkan 1 klik saja! 


\section{Modul 1}

\section{Pengurusan dan Pembuatan Badan Usaha}

\section{Penjelasan Umum Pengurusan dan Pembuatan Badan Usaha}

Dalam Modul ini kami akan membahas mengenai pengurusan pendirian Badan Usaha di Indonesia.

Output:

- Peserta memahami jenis-jenis badan usaha yang akan dipilih

- Peserta memahami proses pembuatan badan usaha

- Peserta memahami pihak yang dapat membantu membuat badan usahanya Estimasi durasi untuk mengerjakan secara mandiri : 1- 2 jam

Dukungan yang dibutuhkan

- Pendampingan Notaris atau praktisi untuk membantu melakukan pengurusan pembentukan badan usaha

- Membahas bersama UKM lain yang sejenis sektor usahanya perihal proses badan usaha yang dipilih oleh mereka

\section{Modul}

\section{Mengenai Pengurusan Badan Usaha Proses Pembuatan masing-masing Badan Usaha}

Berikut ini akan diuraikan mengenai proses- proses yang perlu dilalui untuk membuat sebuah badan usaha.

\section{Badan Usaha Non Badan Hukum}

Perusahaan Perorangan

Terhadap kegiatan usaha ini tidak diperlukan sebuah proses hingga terbentuk sebuah badan usaha.

Khusus untuk Usaha Dagang maka dibutuhkan beberapa proses yang diperlukan untuk diterima sebagai sebuah usaha dagang.

1. Perseorangan meminta kepada pihak notaris untuk membuat akta pendirian dari sebuah Usaha Dagang yang pada Pokoknya berisikan Nama Usaha Dagang, Domisili Usaha Dagang, Pemilik Usaha Dagang.

2. Setelah Akta Pendirian Usaha Dagang selesai dibentuk, Perseorangan dapat 
melakukan pendaftaran Akta tersebut di Pengadilan Tempat Domisili Usaha Dagang dibuat.

3. Kemudian melakukan pendaftaran untuk memintakan Izin Usaha Pedagang Perseorangan kepada Dinas Koperasi dan Usaha Kecil dan Menengah daerah Setempat

4. Melakukan pendaftaran dan permintaan izin sesuai dengan jenis kegiatan usaha yang dilakukan

\section{Persekutuan Perdata}

Persekutuan Perdata didirikan berdasarkan perjanjian diantara para pendirinya yang merupakan subjek hukum baik Perorangan maupun Badan Hukum, yang dituangkan di dalam Akta Pendirian yang dibuat oleh Notaris.

Proses yang perlu dilakukan cukup membuat perjanjian antara para pendiri yang dapat berisikan hal-hal terkait dengan apa saja yang akan dikerjakan didalam persekutuan, apa saja yang akan dimasukan kedalam persekutuan, bagaimana pembagian keuntungan didalam persekutuan dan sampaikan persekutuan akan dijalankan.

- Firma Firma didirikan berdasarkan persetujuan tertulis diantara para pendirinya dalam bentuk Akta Notaris. Namun, Firma juga dapat dibentuk dengan Akta Bawah Tangan (tidak dibuat dihadapan notaris) dan dianggap tetap sah terhadap Pihak Ketiga.

Berikut ialah proses yang dilakukan apabila dibuat dihadapan Notaris:

1. Para pendiri yang akan melakukan pendirian membuat perjanjian yang nantinya akan disebut sebagai Akta Pendirian.

2. Akta pendirian kemudian dibuat oleh Notaris bersama dengan para pendiri

3. Sesudah Akta Pendirian dibuat, Akta Pendirian tersebut wajib didaftarkan di kepaniteraan Pengadilan Negeri tempat domisili Firma dibentuk.

4. Ikhtisar dari Akta Pendirian juga wajib diumumkan dalam Berita Negara.

5. Melakukan pendaftaran dan permintaan izin sesuai dengan jenis kegiatan usaha yang dilakukan 
Tujuan pendaftaran Akta Pendirian agar masyarakat umum atau pihak ketiga yang berkepentingan dapat mengetahui Informasi tentang siapa saja anggota sekutunya, dimana domisili firma tersebut.

- Persekutuan Komanditer (CV) CV didirikan berdasarkan persetujuan tertulis diantara para pendirinya dalam bentuk Akta Notaris. Namun, CV juga dapat dibentuk dengan Akta Bawah Tangan (tidak dibuat dihadapan notaris) dan dianggap tetap sah terhadap Pihak Ketiga.

Berikut ialah proses yang dilakukan apabila dibuat dihadapan Notaris:

1. Para pendiri yang akan melakukan pendirian membuat perjanjian yang nantinya akan disebut sebagai Akta Pendirian.

2. Akta pendirian kemudian dibuat oleh Notaris bersama dengan para pendiri

3. Sesudah Akta Pendirian dibuat, Akta Pendirian tersebut wajib didaftarkan di kepaniteraan Pengadilan Negeri tempat domisili CV dibentuk.

4. Ikhtisar dari Akta Pendirian juga wajib diumumkan dalam Berita Negara.

5. Melakukan pendaftaran dan permintaan izin sesaui dengan jenis kegiatan usaha yang dilakukan

Tujuan pendaftaran Akta Pendirian agar masyarakat umum atau pihak ketiga yang berkepentingan dapat mengetahui Informasi tentang siapa saja anggota sekutunya, dimana domisili CV tersebut.

\section{Badan Usaha berbentuk Badan Hukum}

\section{Perseroan Terbatas (PT)}

Untuk mendirikan PT, terdapat beberapa syarat yang harus dipenuhi supaya pendirian Perseroan sah sebagai badan hukum. diantaranya adalah :

1. Pemesanan nama PT dapat dilakukan oleh pendirinya maupun notaris yang dikuasakan melalui Dirjen AHU Kemenkumham. Saat pemesanan nama PT dapat mengajukan maksimal 3 (tiga) calon nama yang nantinya akan mendapat persetujuan dari Dirjen AHU Kemenkumham mengenai nama PT yang dapat digunakan.

(1) Pendirian PT didasarkan atas perjanjian yang dibuat oleh para pendirinya (subjek hukum) untuk membentuk suatu Perseroan Terbatas. Subjek hukum disini adalah orang pribadi maupun Badan Hukum (PT, Koperasi dan Yayasan). sehingga 
dimungkinkan bahwa pendiri PT adalah perorangan dengan perorangan, perorangan dengan badan hukum maupun badan hukum dengan badan hukum.

(2) Penyusunan Anggaran Dasar yang menjadi landasan bagi Perseroan Terbatas dalam melakukan kegiatan usahanya dengan bantuan Notaris untuk dituangkan dalam bentuk akta pendirian. Pendirian PT harus dibuat dengan Akta Otentik sebagai syarat untuk disahkan oleh Kementerian Hukum dan Ham.

(3) Akta Pendirian juga harus memuat keterangan lainnya yang sekurang-kurangnya memuat :

- Nama lengkap, tempat dan tanggal lahir, pekerjaan, tempat tinggal dan kewarganegaraan pendiri perseorangan (bagi pendiri perorangan) atau nama, tempat kedudukan dan alamat lengkap serta nomor dan tanggal keputusan Menteri mengenai pengesahan badan hukum dari pendiri Perseroan (bagi pendiri yang merupakan badan hukum)

- Nama lengkap, tempat dan tanggal lahir, pekerjaan, tempat tinggal, kewarganegaraan anggota Direksi dan Dewan.Komisaris yang pertama kali diangkat

- Nama Pemegang daham yang telah mengambil bagian saham, rincian jumlah saham dan nilai nominal saham yang telah ditempatkan dan disetor Akta Pendirian wajib dibuat dalam bahasa Indonesia

Akta Pendirian yang sudah dibuat, kemudian diajukan kepada Kementerian Hukum dan HAM untuk mendapatkan pengesahan sehingga memperoleh status badan hukum. Apabila pengajuan akan pengesahan mendapat penolakan, maka diberikan kesempatan paling lambat 30 hari kerja untuk membetulkan hal-hal yang menjadi dasar penolakan dari pengesahan tersebut.

\section{- Koperasi}

Dalam proses pembentukan sebuah Koperasi terdapat berbagai tahapan-tahapan yang dilakukan bersama dengan pihak Dinas Koperasi dan Usaha Kecil Menengah.

1. Para pendiri Koperasi perlu memiliki calon anggota sebanyak 20 Orang termasuk 
dengan para pendiri.

2. Para pendiri beserta dengan calon anggota akan mendapatkan kegiatan penyuluhan terkait dengan pembentukan koperasi dari Dinas Koperasi dan Usaha Kecil Menengah.

3. Telah melaksanakan Rapat Pendirian Koperasi yang didalamnya termuat berita acara rapat pendirian koperasi dan daftar hadir rapat pendirian koperasi

4. Para Pendiri beserta dengan calon anggota membuat Akta Pendirian Koperasi bersama dengan Notaris Terdaftar dan Memiliki Sertifikasi Khusus dibidang Koperasi

5. Surat bukti tersedianya modal yang jumlahnya sekurang-kurangnya sebesar simpanan pokok dan simpanan wajib yang telah dilunasi oleh para pendiri

6. Telah memiliki rencana kegiatan usaha koperasi selama paling sedikit 3 tahun kedepan dan rencana anggaran belanja dan pendapatan koperasi.

7. Telah memiliki Daftar susunan pengurus, pengawas koperasi disertai dengan surat pernyataan tidak mempunyai hubungan keluarga antara pengurus, Daftar sarana kerja Koperasi dan Struktur organisasi Koperasi.

8. Seluruh dokumen tersebut dikirimkan kepada pejabat terkait di Dinas Koperasi dan Usaha Kecil Menengah untuk dilakukan pemeriksaan secara administrasi dan substansi serta dilakukan pemeriksaan secara langsung terkait keberadaan koperasi tersebut.

9. Setelah pemeriksaan secara langsung Pihak Kementerian Koperasi dan Usaha Kecil dan Menengah mengeluarkan Surat Keputusan terkait dengan pengesahan dari Koperasi.

10. Apabila dapat terhadap terjadi penolakan, pihak pendiri melakukan permintaan ulang pengesahan akta pendirian koperasi.

11. Bila dalam proses ini koperasi tidak juga mendapatkan pengesahan maka permohonan lanjutan tidak dapat diterima.

Terhadap penyelenggaraan kegiatan usaha berbasis Koperasi membutuhkan hubungan secara langsung dengan pemerintah daerah maupun dinas-dinas terkait yang dapat menyokong pembentukan serta penyelenggaraan koperasi dikemudian hari. 


\section{Studi Kasus}

1. Terhadap jenis badan usaha yang telah anda sudah pilih, coba anda lakukan pemetaan terhadap dokumen-dokumen apa saja yang telah anda miliki dan dokumen apa yang belum anda miliki.

2. Jika memilih Perseroan Terbatas, dapatkah anda mencoba membuat kerangka dasar akta pendirian yang akan anda buat.

\begin{tabular}{|l|l|}
\hline Calon Nama PT & 1. 2. 3. \\
\hline Pemegang Saham & 1.2. \\
\hline Maksud dan Tujuan PT &. \\
\hline
\end{tabular}

\begin{tabular}{|l|l|}
\hline Modal Dasar & \\
\hline Nominal Saham & \\
\hline Modal Ditempatkan dan Disetor & \\
\hline Susunan Direksi & 1.2. \\
\hline Dewan Komisaris & 1.2. \\
\hline
\end{tabular}




\section{Modul 1}

\section{Menentukan Segmentasi Pelanggan Sederhana}

Hal terpenting yang perlu dilakukan saat menentukan target pelanggan adalah membuat segmentasi pelanggan.

Dalam pengertian sederhana, segmentasi pelanggan dapat diartikan sebagai pengelompokkan tertentu pelanggan potensial Anda berdasarkan kemiripan tertentu. Cara praktis menentukan target pelanggan adalah dengan memilih segmentasi pelanggan yang tepat. Berikut ini adalah langkah praktis yang bisa Anda lakukan untuk menentukan target pelanggan:

\section{Pilih Lokasi yang Menjadi Target menjual produk / jasa Anda}

Pertama adalah tentang geografis. Tentukanlah lokasi mana saja yang dijangkau oleh bisnis Anda. Ada banyak cara untuk menentukan lokasi yang akan menjadi target pasar. Misalnya: berdasarkan kota, kabupaten, provinsi, atau bisa juga berdasarkan radius. Jangan mendefinisikan target lokasi terlalu umum atau luas. Kesalahan ini biasanya terjadi pada toko online yang hanya menyebutkan "Seluruh Indonesia" sebagai target pasarnya.

Pemilihan lokasi target pasar tidak sama dengan lokasi mana yang dijangkau oleh kurir pengiriman barang Anda. Jika toko online Anda memang melayani pengiriman barang ke seluruh Indonesia, minimal buatlah prioritas lokasi yang Anda bidik.

\section{Tentukan Karakteristik Demografi Pelanggan Anda}

Setelah faktor geografi selanjutnya adalah demografi. Kelompokan pelanggan potensial Anda berdasarkan jenis kelamin, usia, agama, pendidikan, pekerjaan, penghasilan, dan faktor demografi lainnya. Anda tidak perlu menggunakan semua contoh di atas, yang penting sudah mendefiniskan siapa pelanggan potensial Anda.

\section{Cari Tahu Bagaimana Psikologis Pelanggan Anda}

Segmentasi pelanggan berdasarkan faktor psikologis atau psikografis ini adalah segmentasi yang paling banyak ragamnya. Kepribadian, kebiasaan, sikap, dan cara pengambilan keputusan adalah beberapa faktor psikografis yang bisa menjadi segmentasi pasar tersendiri. Menargetkan anak-anak "alay" misalnya, itu adalah contoh segmentasi psikografis.

\section{Contoh Membuat Target Pelanggan}

Anda sudah mengetahui 3 cara praktis menentukan target pasar, sekarang 
mari kita lihat contoh penggunaanya berikut ini.

Misalkan Anda memiliki bisnis di bidang fashion untuk anak-anak, maka inilah contoh target pasar Anda.

\section{Produk yang Dijual:}

Pakaian Anak-anak, dijual secara online

\section{Target Lokasi:}

Kota-kota besar seperti Jakarta, Bandung, Surabaya, dan kota lain yang dapat dijangkau oleh kurir pengiriman barang maksimal dalam 3 hari.

\section{Target Demografi Pelanggan:}

Perempuan yang telah menikah dan memiliki anak kecil dengan usia antara $25-40$ Tahun. Memiliki penghasilan keluarga di atas 3 Juta per bulan.

\section{Karakteristik Psikologis Pelanggan:}

Terbiasa menggunakan komputer, email, internet, dan social media. Mengikuti trend fashion anak. Hobi membaca majalah kesehatan anak.

Dengan menentukannya, Anda akan lebih mudah saat menentukan strategi pemasaran dan memilih media promosi yang tepat.

Sekarang cobalah untuk membuat target pasar untuk bisnis Anda pada lembar kerja terlampir berikut ini. 
Hari / Tanggal :

Nama Usaha:

Produk yang Dijual:

Target Lokasi:

Target Demografi Pelanggan:

Karakteristik Psikologis Pelanggan: 


\section{Modul 1}

\section{Pengurusan Izin Usaha Penjelasan Umum Pengurusan Izin Usaha}

Dalam Modul ini kami akan membahas mengenai pengurusan perizinan badan usaha di Indonesia.

Output:

1. Peserta memahami jenis-jenis perizinan yang akan dipilih

2. Peserta memahami proses perizinan usaha

3. Peserta memahami pihak yang dapat membantu memproses perizinannya Estimasi durasi untuk mengerjakan secara mandiri : 1-2 jam

Dukungan yang dibutuhkan

- Pendampingan pemerintah daerah setempat yang menangani perizinan usahauntuk membantu melakukan pengurusan perizinan

- Membahas bersama UKM lain yang sejenis sektor usahanya perihal proses perizinan yang dipilih oleh mereka

\section{Modul Mengenai Pengurusan Izin Usaha}

1 Tahap Pengurusan Izin Usaha

\section{Surat Keterangan Domisili Usaha (SKDU)}

Dalam membuat sebuah Surat Keterangan Domisili Usaha setiap pelaku usaha wajib mempersiapkan beberapa dokumen :

1. Kartu Tanda Penduduk (KTP) pemilik/pendiri Badan Usaha UKM (asli dan fotokopi)

2. Kartu Keluarga (KK) pemilik/pendiri (asli dan fotokopi)

3. Akta Pendirian Badan Usaha dari Notaris (fotokopi)

4. Surat Pernyataan Tidak Keberatan dari tetangga (ditanda tangani minimal 4 orang warga yang bertetangga dengan tempat usaha Anda, dilampiri fotokopi KTP masing-masing)

5. Surat Perjanjian Sewa-Menyewa tempat usaha bermaterai (fotokopi), jika Anda menyewa tempat usaha Anda

6. Surat bukti kepemilikan tanah tempat usaha seperti Surat Tanah/Akta Jual 
Beli/Girik jika tempat usaha Anda milik Anda sendiri Surat Kuasa jika pengurusan dikuasakan ke orang lain.

Dokumen lain yang sekiranya diperlukan, bisa ditanyakan ke Kantor Kelurahan tempat Kegiatan Usaha beroperasi.

Prosedur yang perlu dilakukan untuk mendapakan izin SKDU dapat dilakukan di Kelurahan/Kantor Kepala Desa setempat, berikut ialah proses pengurusannya:

1. Tindakan yang pertama kali perlu anda lakukan adalah untuk meminta surat pengantar dari RT dan RW setempat yang menyatakan bahwa kegiatan usaha yang anda buat benar-benar ada di lingkungan tersebut.

2. Setelah memiliki surat pengantar RT dan RW serta berkas persyaratan yang telah disiapkan, Anda kemudian datang ke Kantor Kelurahan atau Kantor Kepala Desa. Di sana Anda bisa meminta formulir permohonan SKDU ke petugas kelurahan/desa yang kemudian dapat Anda isi dengan benar dan lengkap. Setelah syarat-syarat terpenuhi anda dapat mengungu keperluaan SKDU untuk dikeluarkan dari pihak Kelurahan/Desa. Di beberapa daerah syarat dari dikeluarkan sebuah SKDU adalah pengurusan hingga ke kecamatan untuk meminta pengesahan dari Camat.

\section{Nomor Pokok Wajib Pajak (NPWP)}

Dalam membuat sebuah Nomor Pokok Wajib Pajak setiap pelaku usaha wajib mempersiapkan beberapa dokumen :

1. Fotokopi Akta Pendirian atau dokumen pendirian dan perubahan bagi Wajib Pajak badan dalam negeri atau surat keterangan penunjukan dari kantor pusat bagi bentuk usaha tetap;

a. fotokopi Kartu Nomor Pokok Wajib Pajak salah satu pengurus, atau fotokopi paspor dan surat keterangan tempat tinggal dari Pejabat Pemerintah Daerah sekurang-kurangnya Lurah atau Kepala Desa; dan

b. fotokopi dokumen izin usaha dan/atau kegiatan yang diterbitkan oleh instansi yang berwenang atau surat keterangan tempat kegiatan usaha dari Pejabat Pemerintah Daerah sekurang-kurangnya Lurah atau Kepala Desa atau lembar tagihan listrik dari Perusahaan Listrik/bukti pembayaran listrik.

Prosedur yang perlu dilakukan untuk mendapakan NPWP dapat dilakukan di Kantor 
Pelayanan Pajak setempat atau melalui situs prosedur pendaftaran secara online ereg.pajak.go.id. Berikut ialah pendaftaran online:

(1) Di laman Dirjen Pajak tersebut, pilih menu sistem e-Registration.

(2) Jika Anda belum pernah mendaftarkan diri, silakan mendaftar terlebih dahulu untuk mendapatkan akun dengan mengklik "daftar". Isilah data pendaftaran pengguna dengan benar seperti nama, alamat email, kata sandi (password), dan lainnya. Setelah semua terisi, klik "Save".

(3) Melakukan aktivasi akun yang telah anda daftarkan, Cara mengaktivasi akun Anda adalah dengan membuka kotak masuk (inbox) dari email yang Anda gunakan untuk mendaftar tadi, kemudian buka email yang masuk dari Dirjen Pajak. Ikuti petunjuk yang ada di dalam email tersebut untuk melakukan aktivasi.

(4) Setelah proses aktivasi berhasil dilakukan, selanjutnya Anda harus login ke sistem eRegistration dengan memasukkan email dan password akun yang telah Anda buat. Atau Anda bisa mengklik tautan yang terdapat di dalam email aktivasi kedua dari Dirjen Pajak. Setelah login, Anda akan dibawa ke halaman Registrasi Data WP untuk memulai proses pembuatan NPWP. Silakan mengisi semua data dengan benar pada formulir yang tersedia. Ikuti semua tahapannya secara teliti. Bila data yang diisi benar, akan muncul surat keterangan terdaftar sementara.

(5) Setelah semua data pada formulir pendaftaran terisi lengkap, pilih tombol daftar untuk mengirim Formulir Registrasi Wajib Pajak secara elektronik ke Kantor Pelayanan Pajak tempat Wajib Pajak terdaftar.

a. Selanjutnya Anda harus mencetak dokumen berikut seperti yang tampak pada layar komputer:

b. Formulir Registrasi Wajib Pajak

c. Surat Keterangan Terdaftar Sementara

d. Setelah Formulir Registrasi Wajib Pajak dicetak, silakan ditandatangani, kemudian sertakan berkas dokumen persyaratan yang telah disiapkan sebelumnya.

e. Setelah berkas kelengkapannya siap, Anda harus mengirimkan Formulir Registrasi Wajib Pajak, Surat Keterangan Terdaftar Sementara yang sudah ditandatangani, 
beserta dokumen lainnya ke Kantor Pelayanan Pajak (KPP) tempat badan/perusahaan Anda sebagai Wajib Pajak terdaftar. Berkas tersebut dapat diserahkan langsung ke KPP atau melalui Pos Tercatat. Pengiriman dokumen ini harus dilakukan paling lambat 14 hari setelah formulir terkirim.

f. Jika Anda tidak ingin repot-repot menyerahkan atau mengirimkan berkas secara langsung atau melalui pos ke KPP, Anda dapat memindai (scan) dokumen Anda dan mengunggahnya dalam bentuk digital (soft file) melalui aplikasi e-Registration tadi.

g. Cek status dan tunggu kiriman kartu NPWP kepada domisili anda.

\section{Surat Izin Usaha Perdagangan (SIUP)}

Dalam membuat sebuah Surat Izin Usaha Perdagangan setiap pelaku usaha wajib mempersiapkan beberapa dokumen sesuai bentuk badan Usahanya.

- Untuk Perseroan Terbatas (PT)

- Fotokopi Kartu Tanda Penduduk (KTP) Seluruh Pendiri

- Fotokopi Kartu Keluarga (KK) Direktur Utama

- Fotokopi NPWP Seluruh Pendiri

- Surat Keterangan Domisili Usaha atau SITU

- Fotokopi Akta Pendirian PT yang disahkan oleh Menteri Hukum dan HAM.

- Fotokopi Surat Keputusan Pengesahan Badan Hukum dari Menteri Hukum dan HAM

- Surat Izin Gangguan (HO) bila melakukan kegiatan usaha yang dalam menjalankan kegiatan usahanya

- Izin Prinsip bila merupakan Perusahaan Modal Asing yang membuat Perseroan Terbatas di Indonesia

- Neraca perusahaan, tidak termasuk gedung, tanah, bangunan dan utang, disertai tanda tangan, materai 6000 dan stempel perusahaan

- Pas foto Direktur Utama dengan ukuran 4 × 6/ 3 × 42 lembar/ 3 lembar (Kebutuhan jumlah Pas Foto bervariasi bergantung daerah tertentu)

- Materai Rp6.000

- Izin teknis dari instansi terkait jika diminta - Untuk Koperasi 
- Fotokopi Kartu Tanda Penduduk (KTP) Dewan Pengurus dan Dewan Pengawas Koperasi

- Fotokopi NPWP Dewan Pengurus dan Dewan Pengawas Koperasi

- Fotokopi Akta Pendirian Koperasi yang telah disahkan instansi berwenang

- Daftar susunan Dewan Pengurus dan Dewan Pengawas

- Fotokopi SITU dari Pemerintah Daerah (Pemda)

- Neraca koperasi, tidak termasuk gedung, tanah, bangunan dan utang, disertai tanda tangan, materai 6000 dan stempel koperasi

- Materai senilai Rp6.000

- Pasfoto Pengurus Utama dengan ukuran 4 x 6/ 3 × 42 lembar/ 3 lembar (Kebutuhan jumlah PasFoto bervariasi bergantung daerah tertentu)

- Izin lain yang terkait (Misalnya jika usaha Anda menghasilkan limbah, Anda harus memiliki izin AMDAL dari Badan pengendalian Dampak Lingkungan Daerah) setempat. - Untuk CV dan Firma

- Fotokopi Kartu Tanda Penduduk (KTP) Para Sekutu

- Fotokopi NPWP Para Sekutu

- Fotokopi Akta Pendirian Firma/CV yang telah disahkan instansi berwenang

- Surat Keterangan Domisili Usaha atau SITU

- Neraca CV/ Firmai, tidak termasuk gedung, tanah, bangunan dan utang, disertai tanda tangan, materai 6000 dan stempel koperasi

- Materai senilai Rp6.000

- Pasfoto Pengurus Utama dengan ukuran 4 x 6/ 3 x 42 lembar/ 3 lembar (Kebutuhan jumlah PasFoto bervariasi bergantung daerah tertentu)

- Izin lain yang terkait (Misalnya jika usaha Anda menghasilkan limbah, Anda harus memiliki izin AMDAL dari Badan pengendalian Dampak Lingkungan Daerah) setempat.

Untuk Perusahaan Perseorangan

- Fotokopi Kartu Tanda Penduduk (KTP) Perusahaan Perseorangan

- Fotokopi NPWP

- Surat keterangan domisili atau SITU 
- Neraca perusahaan, tidak termasuk gedung, tanah, bangunan dan utang, disertai tanda tangan, materai 6000 dan stempel usaha dagang

- Materai senilai Rp6.000

- Foto Direktur Utama/Penanggung Jawab/pemilik perusahaan dengan ukuran 4 x $6 \mathrm{~cm}$ (2 lembar).

- Izin lain yang terkait usaha yang dijalankan. Prosedur yang perlu dilakukan untuk mendapakan izin SIUP dapat dilakukan di Kantor Dinas Perdagangan ataupun melalui Pelayanan Terpadu Satu Pintu di Beberapa Daerah.

1. Tindakan yang dapat dilakukan pertama kali adalah mempersiapkan seluruh dokumen yang dibutuhkan dalam rangka pembuatan SIUP.

2. Mengambil formulir untuk permohonan SIUP di Kantor Dinas Perdagangan atau Pelayanan Terpadu Satu Pintu, kemudian melakukan pengisian terhadap formulir yang dan dibuat dalam 2 rangkap. Serta menyerahkan dokumen yang dibutuhkan untuk pembuatan SIUP. Apabila melalui kuasa dalam permohonan harus diberikan surat kuasa kepada para pihak yang dikuasakan dalam mengerjakan pengurusan.

3. Membayar Tarif pembuatan SIUP kepada loket ataupun rekening dari lembaga pemberi pendaftaran. Dibeberapa daerah pengurusan SIUP tidak dikenakan biaya sedikit pun.

\section{Tanda Daftar Perusahaan}

Dalam membuat sebuah Tanda Daftar Perusahaan setiap pelaku usaha wajib mempersiapkan beberapa dokumen sesuai bentuk badan Usahanya.

- Formulir diisi dan di Foto copy $2 X$

- Foto copy Akta Perusahaan/Akta Perubahan.

- Foto copy dan asli pengesahan dari kehakiman/pengadilan untuk CV dan FIRMA/ SK Pengesahan Kemenkumham untuk PT

- Foto copy SIUP atau Ijin Lainnya.

- Foto copy NPWP Perusahaan

- Foto copy KTP Direktur Utama

- Foto copy Domisili Perusahaan 
Prosedur yang perlu dilakukan untuk mendapatkan TDP dapat dilakukan di Kantor Dinas Perdagangan ataupun melalui Pelayanan Terpadu Satu Pintu di Beberapa Daerah.

1. Tindakan yang dapat dilakukan pertama kali adalah mempersiapkan seluruh dokumen yang dibutuhkan dalam rangka pembuatan TDP.

2. Mengambil formulir untuk permohonan TDP di Kantor Dinas Perdagangan atau Pelayanan Terpadu Satu Pintu, kemudian melakukan pengisian terhadap formulir yang dan dibuat dalam 2 rangkap. Serta menyerahkan dokumen yang dibutuhkan untuk pembuatan TDP . Apabila melalui kuasa dalam permohonan harus diberikan surat kuasa kepada para pihak yang dikuasakan dalam mengerjakan pengurusan.

3. Membayar Tarif pembuatan TDP kepada loket ataupun rekening dari lembaga pemberi pendaftaran. Dibeberapa daerah pengurusan TDP tidak dikenakan biaya.

\section{BPJS Ketenagakerjaan}

Dalam membuat sebuah BPJS Ketenagakerjaan setiap pelaku usaha wajib mempersiapkan beberapa dokumen sesuai bentuk badan Usahanya.

- Fotokopi dan aslinya SIUP (Surat Izin Usaha Perdagangan)

- Fotokopi dan aslinya NPWP Perusahaan

- Fotokopi dan aslinya Akta Perdagangan Perusahaan

- Fotokopi KTP (Kartu Tanda Penduduk) masing- masing karyawan,

- Fotokopi KK (Kartu Keluarga) karyawan/pekerja yang akan di daftar,

- Pas Foto berwarna Karyawan/pekerja ukuran 2×3 1 Lembar.

Prosedur yang perlu dilakukan untuk mendapakan BPJS Ketenagakerjaan dapat dilakukan di Kantor BPJS Ketenagakerjaan di Wilayah Domisili perusahaan ataupun melalui https://eps.bpjsketenagakerjaan.go.id/

Pendiri dapat melakukan pendaftaran terhadap kegiatan usaha melalui laman internet kemudian setelah dilakukan pendaftaran terhadap kegiatan usaha beserta dengan syaratsyarat yang ditentukan.

Pendiri melakukan pendaftaran terhadap pekerja- pekerja yang didaftarkan atas nama perusahaan beserta syarat-syarat yang ditentukan.

Menunggu jawaban dari pihak BPJS terkait dengan pendaftaran BPJS 
Ketenagakerjaan.

\section{Tanda Daftar Usaha Pariwisata}

Dalam membuat sebuah Tanda Daftar Usaha Pariwisata setiap pelaku usaha pariwisata wajib mempersiapkan beberapa dokumen sesuai bentuk badan Usahanya.

- Fotokopi akta pendirian badan usaha yang mencantumkan usaha pariwisata sebagai maksud dan tujuannya, beserta perubahannya apabila ada untuk pengusaha yang berbentuk badan hukum, atau fotokopi kartu tanda penduduk untuk pengusaha perseorangan.

- Fotokopi bukti hak pengelolaan dari pemilik usaha pariwisata.

- Fotokopi izin teknis dan dokumen lingkungan hidup sebagai lampiran permohonan

harus telah dilegalisir/disahkan oleh instansi teknis yang berwenang yaitu :

○ Izin mendirikan bangunan ( IMB )

O Izin Gangguan ( $\mathrm{HO}$ )

o Surat Izin Tempat Usaha ( SITU )

○ Amdal/UKL/UPL atau SPPL.

- Surat pernyataan keabsahan dan kebenaran dokumen Prosedur yang perlu dilakukan untuk mendapakan Tanda Daftar Usaha Pariwisata dapat dilakukan di Kantor Dinas Pariwisata/Penanaman Modal ataupun melalui Pelayanan Terpadu Satu Pintu di Beberapa Daerah. Tindakan yang dapat dilakukan pertama kali adalah mempersiapkan seluruh dokumen yang dibutuhkan dalam rangka pembuatan TDUP.

Mengambil formulir untuk permohonan TDUP di Kantor Dinas Pariwisata/Penanaman Modal atau Pelayanan Terpadu Satu Pintu, kemudian melakukan pengisian terhadap formulir yang dan dibuat dalam 2 rangkap. Serta menyerahkan dokumen yang dibutuhkan untuk pembuatan TDUP. Apabila melalui kuasa dalam permohonan harus diberikan surat kuasa kepada para pihak yang dikuasakan dalam mengerjakan pengurusan.

Membayar Tarif pembuatan TDUP kepada loket ataupun rekening dari 
lembaga pemberi pendaftaran. Dibeberapa daerah pengurusan TDUP tidak dikenakan biaya.

\section{Surat Keterangan Industri Kecil Rumah Tangga (SKIKRT)}

Dalam membuat sebuah SKIKRT setiap pelaku usaha pariwisata wajib mempersiapkan beberapa dokumen sesuai bentuk badan Usahanya.

a. Mengisi formulir permohonan

b. Fotokopi KTP pengurus

c. Fotokopi NPWP (Nomor Pokok Wajib pajak)

d. Fotokopi Akta Pendirian Perusahaan (bagi yang berbadan hukum)

e. Surat Keterangan Domisili Usaha

f. Kegiatan Usaha Produksi dengan Nilai investasi yang lebih dari Rp 50 juta harus melampirkan Izin Gangguan

g. UKL/UPL (Upaya Pengelolaan Lingkungan dan Upaya pemantauan Lingkungan) atau SPPL (Surat Pernyataan Pengelolaan Lingkungan)

h. Pasfoto pengurus $4 \times 6$ sebanyak 2 lembar

Prosedur yang perlu dilakukan untuk mendapakan SKIKRT dapat dilakukan di Kantor Dinas Parindustrian ataupun melalui Pelayanan Terpadu Satu Pintu di Beberapa Daerah.

Tindakan yang dapat dilakukan pertama kali adalah mempersiapkan seluruh dokumen yang dibutuhkan dalam rangka pembuatan SKIKRT.

Mengambil formulir untuk permohonan SKIKRT di Kantor Dinas Perindustrian atau Pelayanan Terpadu Satu Pintu, kemudian melakukan pengisian terhadap formulir yang dan dibuat dalam 2 rangkap. Serta menyerahkan dokumen yang dibutuhkan untuk pembuatan SKIKRT. Apabila melalui kuasa dalam permohonan harus diberikan surat kuasa kepada para pihak yang dikuasakan dalam mengerjakan pengurusan. Membayar Tarif pembuatan SKIKRT kepada loket ataupun rekening dari lembaga pemberi pendaftaran. Dibeberapa daerah pengurusan SKIKRT tidak dikenakan biaya.

\subsection{Studi Kasus}

Buatlah Dokumen persyaratan SIUP sesuai dengan dokumen-dokumen ataupun 
pengetahuan saudara terkait kegiatan usaha saudara. Dalam menentukan SIUP ini saudara dapat memilih 3 buah jenis usaha berdasarkan Klasifikasi Baku Lapangan Usaha yang dapat diunduh dari tautan ini: ।

http://www2.bkpm.go.id/images/uploads/prosedur_investasi/file_upload/KBLI2015.pdf

\begin{tabular}{|l|l|}
\hline Nama Perusahaan & \\
\hline Bentuk Perusahaan & . \\
\hline
\end{tabular}

\begin{tabular}{|l|l|}
\hline Merek & \\
\hline Alamat Perusahaan & \\
\hline Lokasi Perusahaan & \\
\hline Nomor Telepon/Fax & \\
\hline Status Tempat Usaha & \\
\hline Nomor Pokok Wajib Pajak (NPWP) & \\
\hline Modal Disetor dan Kekayaan Bersih (Netto) & \\
tidak termasuk tanah dan tempat usaha & \\
\hline Kegiatan Usaha Kelembagaan & . \\
\hline
\end{tabular}

\begin{tabular}{|l|l|}
\hline Bidang Usaha Sesuai KBLI & \\
\hline Jenis barang/Jasa Dagangan Utama & \\
\hline
\end{tabular}

2. Perizinan apa sajakah yang telah anda miliki? Isilah kotak dibawah ini apabila anda telah memiliki izin-izin berikut:

\begin{tabular}{|l|l|l|l|}
\hline Jenis Izin & Nomor Izin & Tanggal Dikeluarkan & Tanggal Daluarsa \\
\hline SKDU & & & \\
\hline SIUP & & & \\
\hline TDP & & & \\
\hline NPWP & & & \\
\hline Izin Khusus: & & &.. \\
\hline
\end{tabular}




\section{Modul 1.}

\section{Sistem Penggajian dan Insentif Penjelasan Umum}

\section{Penjelasaan Sistem Penggajian dan Insentif/Bonus}

\subsubsection{Definisi Gaji dan Insentif/bonus}

26.1.2. Dasar - dasar perhitungan gaji \& insentif/bonus

26.1.3. Administrasi penggajian

\section{Tujuan Modul}

Setelah mempelajari dan mengerjakan modul ini peserta akan :

- Memahami perbedaan antara gaji dan insentif/bonus.

- Mengetahui komponen-komponen yang harus diperhatikan dalam perhitungan gaji dan insentif/bonus.

- Memahami cara menetapkan gaji dan insentif/bonus.

- Memahami proses administrasi penggajian. Durasi Durasi mengerjakan secara mandiri : maksimal 6 jam

\section{Dukungan yang dibutuhkan ‘}

- Pendampingan Mentor untuk membahas hasil simulasi penetapan penggajian dan insentif/bons yang telah dikerjakan sebelumnya secara mandiri.

- Sumber informasi yang berisi ketentuan normatif yang harus diperhatikan dalam penggajian.

\section{Lembar Kerja}

\subsection{Definisi Gaji dan Insentif/Bonus}

Sebelum kita mulai, coba Anda tuliskan di kotak bawah ini, apa yang Anda bayangkan bila mendengar kata 'Gaji' dan 'Insenti/Bonus'. Silahkan tuliskan semua yang ada di bayangan Anda mengenai kedua kata tersebut

Menurut saya 


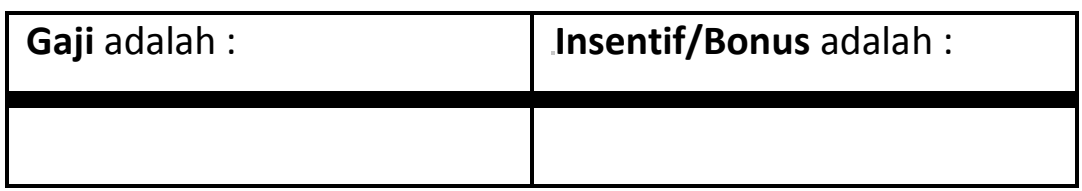

Setelah menulis jawaban Anda, silakan lanjut ke halaman berikutnya. Anda telah menuliskan pendapat Anda masing-masing mengenai Gaji/Upah dan juga Insentif/Bonus. Silakan Anda baca penjelasan di bawah ini dan coba bandingkan dengan pendapat yang telah Anda tulis di halaman sebelumnya.

Definisi,gaji/upah yang disimpulkan dari beberapa sumber adalah "sejumlah uang yang dibayarkan kepada seseorang atas jasa/tenaga yang diberikan kepada perusahaan yang besarannya ditetapkan dan dibayarkan menurut suatu perjanjian kerja, kesepakatan, atau peraturan perundang-undangan". Pembayaran gaji/upah dapat dilakukan secara harian, mingguan atau bulanan tergantung dari kesepakatan kedua belah pihak.

Berdasarkan definisi tersebut di atas dapat disimpulkan bahwa gaji/upah:

a. Jumlah uang tertentu

b. Kompensasi atas hasil kerja

c. Kesepakatan bersama

d. Pemberian dilakukan secara berkala

Besaran gaji/upah dipengaruhi oleh kualifikasi yang dimiliki seseorang seperti pendidikan, pengalaman dan sifat-sifat pribadi.

Definisi insentif/bonus adalah sarana motivasi dengan memberi bantuan sebagai suatu perangsang atau dorongan yang diberikan dengan sengaja kepada para pekerja agar dalam dirinya timbul semangat yang lebih besar untuk berprestasi bagi organisasi. (Sarwoto, 1995,141-142).

Insentif/bonus diberikan atas prestasi atau pencapaian individu dan atau usaha atas target tertentu. Insentif/bonus umumnya diberikan dalam bentuk material (uang/barang) namun dapat juga diberikan dalam bentuk non material seperti kenaikan jabatan atau piagam penghargaan.

Berdasarkan definisi dan penjelasan di atas dapat disimpulkan bahwa insentif/bonus :

a. Pemberiannya untuk meningkatkan motivasi dan prestasi kerja,

b. Pencapaian target individu dan atau usaha, Dapat berbentuk materi maupun non materi. 
Secara harian/mingguan/bulanan atas pekerjaan yang dilakukan, sedangkan insentif/bonus diberikan apabila target tertentu tercapai oleh individu maupun usaha Anda. Setelah Anda mengetahui dan memahami definisi di atas, pada bagian selanjutnya Anda akan mempelajari singkat, gaji/upah diberikan secara dasar-dasar penetapan gaji/upah di tempat Anda.

Pada bagian ini Anda akan mempelajari dasar-dasar penetapan gaji/upah bagi usaha Anda. Fungsi pembayaran gaji/upah bagi adalah untuk mempertahankan pekerja serta memberikan penghargaan atas jerih payah/usaha yang telah mereka berikan bagi usaha. Pekerja yang baik serta termotivasi dalam melaksanakan tugasnya sangat bermanfaat bagi perkembangan usaha Anda.

Anda pastinya telah melakukan pembagian tugas kepada beberapa orang untuk menjalankan produksi atau memberikan jasa sesuai dengan tujuan yang telah ditetapkan.

Pembagian tugas tersebut dilandasi oleh kemampuan/keahlian seseorang di bidang tertentu maupun pengetahuan yang dimiliki atas ilmu tertentu. Misalnya : Seseorang yang ahli memasak pastinya tidak akan ditugaskan untuk mencuci piring/gelas di warung Anda; Seseorang yang memiliki kemampuan menghitung yang baik akan lebih bermanfaat apabila ditugaskan untuk menjadi kasir dalam usaha Anda.

Perbedaan kemampuan/keahlian dan pengetahuan seseorang dapat menjadi dasar dalalm perhitungan gaji di usaha Anda.

Agar Anda dapat lebih memahami cara menentukan Gaji/upah, silahkan Anda diskusikan dan isi Lembar Kerja 1.2 mengenai Dasar - dasar penetapan Gaji/Upah. Dalam Lembar Kerja tersebut terdapat kolom yang berisi Jabatan dan Tugas masing-masing jabatan di Toko Pangkas Rambut, yang perlu Anda lakukan adalah :

a. Mengisi baris "keahlian/pengetahuan" dengan keahllian atau pengetahuan yang diperlukan untuk menjalankan tugas pada jabatan tersebut, dapat lebih dari satu keahlian atau pengetahuan.

b. Pada baris "urutan", silahkan Anda isi dengan urutan pekerjaan yang menurut Anda paling tinggi posisi-nya di Toko Pangkas Rambut dengan memberikan angka "1" untuk yang paling tinggi dan urutkan dengan memberi angka selanjutnya sampai pada akhirnya angka " 5 " menjunjukkan posisi yang paling rendah dalam Toko Pangkas Rambut. 
C. Apabila Anda diberikan uang Rp.10.000.000 untuk pembayaran gaji/upah seluruh jabatan di Toko Pangkas Rambut, kira-kira berapa masing- masing jabatan akan menerima gaji? Silahkan dituliskan pada baris Gaji.

Lembar Kerja 1.2 Dasar - dasar penetapan Gaji/Upah

\begin{tabular}{|c|c|c|c|c|c|}
\hline & $\begin{array}{l}\text { Koordinator } \\
\text { Tukang Cukur }\end{array}$ & Kasir & $\begin{array}{c}\text { Asisten Tukang } \\
\text { Cukur }\end{array}$ & Pimpinan/Bos & Tukang cukur \\
\hline Tugas & $\begin{array}{l}\text { - Mengatur jadwal } \\
\text { kerja tukang } \\
\text { cukur. } \\
\text { - Melaporkan stok } \\
\text { krim rambut, } \\
\text { bedak. } \\
\text { - Mengawasi } \\
\text { pekerjaan tukang } \\
\text { cukur. } \\
\text { - Mempelajari } \\
\text { model rambut. }\end{array}$ & $\begin{array}{l}\text { - Menerima uang } \\
\text { pembayaran } \\
\text { konsumen } \\
\text { - Mencatat } \\
\text { penerimaan harian } \\
\text { - Menyetorkan uang } \\
\text { kepada } \\
\text { Pimpinan/Bos }\end{array}$ & $\begin{array}{l}\text { - Mempersiapkan } \\
\text { alat dan } \\
\text { kebutuhan cukur } \\
\text { - Membersihkan } \\
\text { ruangan cukur }\end{array}$ & $\begin{array}{ll}\text { - } & \text { Mengatur usaha } \\
\text { cukur untuk } \\
\text { mencapai target. } \\
\text { - } & \text { Menetapkan tarif } \\
\text { cukur. } \\
\text { - } \\
\text { Menyediakan } \\
\text { tempat dan } \\
\text { peralatan cukur. } \\
\text { - Mengatur } \\
\text { keuangan. } \\
\text { - Membayarkan } \\
\text { gaji dan insentif. }\end{array}$ & $\begin{array}{l}\text { - Menerima } \\
\text { konsumen } \\
\text { - Mencukur sesuai } \\
\text { dengan } \\
\text { permintaan } \\
\text { konsumen } \\
\text { - Mempelajari } \\
\text { model-model } \\
\text { rambut }\end{array}$ \\
\hline $\begin{array}{l}\text { Keahlia } \\
\text { Penget } \\
\text { n }\end{array}$ & & & & & \\
\hline Urutan & & & & & \\
\hline
\end{tabular}

Anda telah berhasil menentukan gaji masing-masing jabatan di Toko Potong Rambut berdasarkan tugas yang dimiliki oleh masing-masing jabatan, keahlian/pengetahuan yang diperlukan dan juga anggaran yang tersedia.

Dalam menetapkan gaji/upah di usaha Anda hal-hal yang perlu diperhatikan adalah :

a. Tugas dan tanggung jawab

b. Keahlian/Pengetahuan yang dimiliki dan diperlukan

c. Anggaran untuk pembayaran Gaji/Upah.

Fungsi dari gaji/upah adalah mempertahankan pekerja untuk tetap bekerja dengan Anda, oleh karenanya Anda harus memastikan bahwa gaji/upah yang dibayarkan telah sesuai tugas yang dijalankan dan menghargai keahlian/pengetahuan yang dimiliki dan diperlukan. Anda juga harus memperhatikan ketentuan normatif yang berlaku tentang Upah Minimum di Kota/Kabupaten tempat usaha Anda.

Pemberian Insentif/Bonus bagi pekerja Anda adalah untuk memotivasi mereka mencapai target yang telah ditetapkan baik itu target usaha Anda maupun target individu.

Contoh target usaha Anda :

1. Menghasilkan 5.000 keranjang rotan dalam setahun.

2. Melayani tamu tour 1.000 orang wisatawan dalam setahun

3. Menjual peta wisata 1.200 buah per tahun. Contoh target individu 
4. Mengumpulkan bahan baku rotan 10 batang per-hari

5. Menjadi tour guide bagi 15 grup per-bulan

6. Menjual peta wisata 100 peta per-bulan Target individu di suatu usaha Anda, apabila digabungkan akan menjadi target usaha Anda. Penting bagi Anda apabila ingin memberikan insentif/bonus untuk menetapkan target di awal tahun sekaligus menyusun program kerja.

Pada Lembar Kerja 1.3 tentang perhitungan insentif Anda diminta untuk menentukan besaran insentif untuk pekerja di Toko Potong Rambut masing-masing jabatan dengan asumsi Toko Potong Rambut memperoleh keuntungan bersih tahun 2016 sebesar Rp. 20.000.000. Dari keuntungan tersebut Anda akan membagikan 50\% (Rp. 10.000.000) dari keuntungan bersih sebagai insentif/bonus kepada pekerja. Tugas Anda adalah menentukan besaran insentif apabila diberikan :

1. Dengan nilai yang sama bagi seluruh pekerja,

2. Dengan mengacu pada upah pekerja. Silakan Anda isikan nilai pada masing-masing baris "Besaran Insentif sama" dan "Besran Insentif berdasarkan upah"

\section{Lembar Kerja 1.3 Perhitungan Insentif/Bonus}

\begin{tabular}{|l|c|c|c|c|c|}
\hline & $\begin{array}{c}\text { Koordinator } \\
\text { Tukang Cukur }\end{array}$ & Kasir & $\begin{array}{c}\text { Asisten Tukang } \\
\text { Cukur }\end{array}$ & Pimpinan/Bos & Tukang cukur \\
\hline Upah & Rp. 2.000.000 & Rp. 1.250.000 & Rp. 1.000.000 & Rp. 4.500.000 & Rp. 1.250.000 \\
\hline $\begin{array}{l}\text { Besaran } \\
\text { Insentif } \\
\text { sama }\end{array}$ & & & & & \\
\hline $\begin{array}{l}\text { Besaran } \\
\text { Insentif } \\
\text { berdasarkan } \\
\text { Upah }\end{array}$ & & & & & \\
\hline
\end{tabular}

Selamat !!, Anda telah berhasil menentukan besaran insentif dari anggaran yang tersedia dengan menggunakan dua kriteria penentuan, yaitu : Nilai insentif sama bagi seluruh pekerja dan Nilai insentif yang berdasarkan upah masing-masing pekerja.

Pemberian insentif/bonus kepada pekerja dilakukan secara berkala, yang paling umum diberikan satu tahun sekali setelah target tahunan tercapai, namun ada pula yang diberikan per 3 bulan atau per 6 bulan tergantung dari masing-masing perusahaan. Walaupun berbeda jangka waktu pemberiannya, namun pemberian insentif/bonus selalu didasarkan atas pencapaian target tertentu yang telah disepakati bersama.

Apabila Anda akan memberikan insentif/bonus kepada pekerja, pastikan bahwa terdapat 
pencapaian target dan target tersebut diketahui dan disepakati secara bersama- sama sehingga seluruh pekerja di usaha Anda termotivasi untuk mencapai target.

Anda telah mengetahui definisi dan cara menghitung Gaji/Upah serta Insentif/Bonus, dalam bagian selanjutnya Anda akan mempelajari Administrasi Penggajian (cara pembayaran Gaji/Upah).

Proses Administrasi Penggajian terdiri dari beberapa tahapan, yaitu :

Tahap Persiapan

1. Mengumpulkan data gaji seluruh pekerja. Gaji yang diterima oleh pekerja adalah Gaji bersih yang diperoleh dari pemotongan Gaji Kotor dengan pajak, BPJS Ketenagakerjaan dan BPJS Kesehatan yang menjadi porsi pekerja, cicilan pinjaman (jika ada)

2. Mengumpulkan absensi seluruh pekerja (bagi pekerja harian dan perhitungan upah lembur). Upah lembur diberikan kepada pekerja non-staf.

3. Mempelajari ketentuan Pajak Penghasilan (Pendapatan Tidak Kena Pajak), BPJS Ketenagakerjaan (Jaminan Hari Tua), BPJS Kesehatan.

4. Tahap Perhitungan

5. Menghitung pendapatan pekerja berdasarkan gaji dan absensi

6. Menghitung besaran iuran BPJS Ketenagakerjaan (Jaminan Hari Tua).

7. Menghitung pendapatan lainnya seperti Insentif (jika ada), THR (mendekati Idul Fitri)

8. Menghitung potongan pendapatan (BPJS, Pajak, Pinjaman/hutang dll).

9. Tahap Pembayaran

10. Rekap keseluruhan data gaji bulanan.

11. Persetujuan dari atasan.

12. Pembayaran kepada pekerja.

13. Tahap Dokumentasi Pencatatan penerimaan gaji di buku besar/penyerahan slip gaji Berikut adalah contoh rekapitulasi penggajian dengan menggunakan Microsoft Excel 
REKAPITULASI PENGGAJIAN TOKO POTONG RAMBUT

Periode Oktober 2016

\begin{tabular}{|c|c|c|c|c|c|c|c|c|}
\hline No & Nama & Jabatan & Gaji Kotor & $\begin{array}{l}\text { Upah } \\
\text { Lembur }\end{array}$ & Pajak & $\begin{array}{c}\text { Jamina Hari Tua } \\
\text { (BPJS } \\
\text { Ketenagakerjaa } \\
n\end{array}$ & $\begin{array}{c}\text { BPJS } \\
\text { Kesehatan }\end{array}$ & Gaji Bersih \\
\hline & & & & & & & & \\
\hline & & & & & & & & \\
\hline & & & & & & & & \\
\hline & & & & & & & & \\
\hline
\end{tabular}

Yang perlu Anda perhatikan dalam melakukan administrasi penggajian adalah :

1. Besaran Gaji/Upah Kotor pekerja bulanan.

2. Upah lembur (jika ada)

3. Potongan pajak atas Gaji/Upah pekerja (Penghasilan kotor yang disetahunkan kemudian dikurangi PTKP), Penghasilan kotor yang disetahunkan u terdiri dari Gaji/Upah Kotor, THR (Bila ada), Insentif (Bila Ada)

4. Potongan Iuran BPJS Ketenagakerjaan dan BPJS Kesehatan yang menjadi porsi pekerja Anda sekarang telah mengetahui cara administrasi penggajian secara sederhana, prinsipnya adalah ada pendapatan dan potongan atas Gaji/Upah pekerja 


\section{Modul 1}

27.Pelatihan dan Pengembangan Tim Penjelasan Umum

27. Penjelasaan Pelatihan dan Pengembangan Tim

27.1.1. Definisi Pelatihan dan Pengembangan

27.1.2. Acuan penyusunan program Pelatihan dan Pengembangan

27.1.3. Jenis-jenis program Pelatihan dan Pengembangan

27.1.4. Perhitungan anggaran dan Evaluasi program Pelatihan dan Pengembangan

\section{Tujuan Modul}

Setelah mempelajari dan mengerjakan modul ini peserta akan :

- Memahami program Pelatihan dan Pengembangan,

- Menyusun rancangan program Pelatihan dan Pengembangan,

- Mengetahui perbedaan jenis-jenis program Pelatihan dan Pengembangan,

- Menghitung anggaran training

- Memahami poin-poin evaluasi program Pelatihan dan Pengembangan Durasi

Durasi mengerjakan secara mandiri : maksimal 4 jam

Dukungan yang dibutuhkan ‘

- Pendampingan Mentor untuk membahas proses penyusunan program Pelatihan dan Pengembangan dan penentuan jenis-jenis program Pelatihan dan Pengambangan

- Sumber informasi mengenai daftar program Pelatihan dan Pengembangan bagi Usaha Kecil dan Menengah.

\section{Lembar Kerja 1.1 Definisi Program Pelatihan dan Program Pengembangan}

Sebelum kita mulai, coba Anda tuliskan di kotak bawah ini, apa yang Anda bayangkan bila 
mendengar kata "Program Pelatihan" dan "Program Pengembangan". Silahkan tuliskan semua yang ada di bayangan Anda mengenai kedua kata tersebut

\begin{tabular}{|l|l|}
\hline Menurut saya & Program Pengembangan \\
Program Pelatihan adalah: & adalah : \\
\hline & \\
\hline
\end{tabular}

Setelah menulis jawaban Anda, silakan lanjut ke halaman berikutnya.

Anda telah menuliskan pendapat Anda masing-masing mengenai Program Pelatihan dan Program Pengembangan. Orang lebih mengenal Program Pelatihan yang sering disebut sebagai "Training" dibandingkan Program Pengembangan dimana Training dipandang sebagai kegiatan untuk menambah pengetahuan atau keahlian tertentu.

Mari kita bahas lebih jauh lagi mengenai Program Pelatihan dan Program Pengembangan :

\begin{tabular}{|c|c|c|}
\hline & Program Pelatihan & Program Pengembangan \\
\hline Tujuan & $\begin{array}{l}\text { Memberikan pengetahuan, keahlian } \\
\text { dan kemampuan untuk } \\
\text { menjalankan tugas atau pekerjaan } \\
\text { tertentu. }\end{array}$ & $\begin{array}{l}\text { Mempersiapkan pekerja untuk } \\
\text { melaksanakan tugas di masa yang } \\
\text { akan datang sambil meningkatkan } \\
\text { kemampuan untuk menjalankan } \\
\text { tugas saat ini. }\end{array}$ \\
\hline Waktu & Singkat, saat ini & Panjang, masa yang akan datang \\
\hline Manfaat & $\begin{array}{l}\text { Keahlian yang diperoleh melalui } \\
\text { program Pelatihan dapat segera di }\end{array}$ & $\begin{array}{l}\text { Menyiapkan pekerja terhadap } \\
\text { tanggung jawab di masa yang }\end{array}$ \\
\hline
\end{tabular}




\begin{tabular}{|l|l|l|}
\hline & tampilkan & $\begin{array}{l}\text { akan datang sekaligus } \\
\text { meningkatkan kemampuan untuk } \\
\text { menjalankan tugas saat ini }\end{array}$ \\
\hline
\end{tabular}

\begin{tabular}{|l|l|l|}
\hline \multirow{3}{*}{ Contoh } & Operator mesin produksi dilatih & Operator mesin produksi dinilai \\
& menggunakan mesin produksi yang & mempunai potensi sebagai \\
& baru. & diberikan tambahan kesempatan \\
& & belajar untuk meningkatkan \\
& & kemampuan kepemimpinan dia. \\
\hline
\end{tabular}

Berdasarkan tabel di atas Anda telah mengetahui perbedaan antara Program Pelatihan dan Program Pengembangan. Program Pengembangan mempunyai cakupan yang lebih luas dibandingkan dengan Program Pelatihan. Program-program tersebut yang tersusun dan terencana dengan baik dapat mendukung tercapainya kebutuhan individu dan kebutuhan usaha Anda, sehingga dapat memberikan hasil yang optimal bagi usaha Anda.

Anda dapat menyusun Program Pelatihan dan Program Pengembangan bagi pekerja dan usaha Anda dengan mengikuti tahapan - tahapan sebagai berikut :

1. Tahapan Analisa Kebutuhan

- Menentukan kekurangan yang dimiliki oleh pekerja dan dibandingkan dengan kebutuhan usaha.

- Menentukan prioritas pelaksanaan program berdasarkan kebutuhan usaha.

- Contoh : Perusahaan XY baru saja membeli mesin produksi baru buatan Cina, seluruh petunjuk dan buku panduan pada mesin.

tersebut ditulis dalam bahasa Cina. Perusahaan XY memutuskan bahwa agar operasi dapat berjalan lancar dan gangguan pada mesin dapat segera di atasi, maka kepada seluruh operator mesin dan koordinatornya akan dibuatkan kelas khusus Bahasa Cina. 


\section{Tahapan Penyusunan Program}

- Menetapkan tujuan dari program dan materi.

- Menentukan pengajar/pengisi program, jangka waktu pelaksanaan, jumlah peserta, lokasi program dan jumlah absensi/kehadiran.

- Contoh : Pelatihan Bahasa Cina di perusahan XY bertujuan agar operator mesin dan koordinatornya mengerti Bahasa Cina untuk dapat mengoperasikan mesin dengan baik dan memperbaiki gangguan yang ringan, materi yang diberikan oleh pengajar dari Lembaga Bahasa mengenai Bahasa Cina dasar dan untuk operasi mesin, Program dilaksanakan setiap hari Senin dan Kamis selama 1 jam sebelum dan sesudah masingmasing shift dan akan berlangsung selama 24 kali pertemuan.

Tahapan Pelaksanaan Program

- Melaksanakan program sesuai dengan jadwal yang ditentukan.

- Monitor pelaksanaan melalui observasi langsung pada beberapa tahapan program.

- Memberikan dorongan/motivasi kepada peserta untuk belajar dengan baik.

\section{Tahapan Evaluasi Program}

- Menyusun lembar evaluasi program

- Meminta masukan dari peserta dan pengajar tentang kekurangan dan kelebihan dari program ini

- Menentukan apakah tujuan dari pelaksanaan program telah tercapai.

- Contoh: Tujuan pelaksanaan program Bahasa Cina adalah pekerja dapat mengerti Bahasa Cina, dari hasil evaluasi diperoleh bahwa pekerja telah mengerti Bahasa Cina sehingga dapat menjalankan mesin operasi dengan baik. Kehadiran peserta lebih dari $90 \%$ di seluruh sesi. Yang perlu Anda perhatikan dalam penyusunan Program Pelatihan dan Program Pengembangan adalah proses analisa kebutuhan dan juga penentuan tujuan program. Kedua hal tersebut sangat penting agar Program Pelatihan dan Program pengembangan dapat bermanfaat bagi usaha Anda dan juga individu. Setelah Anda mempelajari tahapan penyusunan Program Pelatihan dan Program Pengembangan, sekarang Anda akan mencoba 
menyusun Program Pelatihan dan Program Pengembangan dengan menggunakan tahapantahapan yang telah dijelaskan. Anda dapat menentukan Program Pelatihan dan Program Pengembangan apa yang kira-kira akan dilaksanakan, sebaiknya program tersebut sesuai dengan kebutuhan Anda saat ini. Anda dapat menuliskannya dilembar kerja berikutnya.

\section{Lembar Kerja 1.2 Tahapan Penyusunan Program}

\begin{tabular}{|c|c|}
\hline \multicolumn{2}{|c|}{$\begin{array}{l}\text { Program Pelatihan/ } \\
\text { Program } \\
\text { Pengembangan }\end{array}$} \\
\hline $\begin{array}{l}\text { Cara } \\
\text { Penyampaian }\end{array}$ & Keterangan \\
\hline Presentasi & $\begin{array}{l}\oplus \text { Bermanfaat untuk menyampaikan informasi dan } \\
\text { pengetahuan baru. } \\
\oplus \text { Dapat disampaikan kepada banyak orang secara } \\
\text { bersamaan. } \\
\oplus \text { Biaya murah. } \\
\quad \text { - Komunikasi cenderung searah. } \\
\quad \text { - Jangka waktu presentasi efektif kurang dari } 20 \\
\text { menit. }\end{array}$ \\
\hline Studi Kasus & $\begin{array}{l}\oplus \text { Menganalisa kasus nyata/sebenarnya. } \\
\oplus \text { Mencari alternatif solusi penyelesaian. } \\
\oplus \text { Membantu mengaplikasikan hal yang telah dipelajari. } \\
\text { - Pembahasan terbatas pada kasus yang didiskusikan. }\end{array}$ \\
\hline Membaca & $\begin{array}{l}\oplus \text { Membaca dapat membantu peserta mengingat } \\
\text { kembali } \\
\text { hal yang telah dipelajari. } \\
\quad \oplus \text { Menambah informasi atas hal baru. } \\
\text { - Tidak semua orang senang membaca } \\
\text { - Perlu banyak referensi/sumber informasi }\end{array}$ \\
\hline $\begin{array}{l}\text { Demonstrasi / } \\
\text { Simulasi }\end{array}$ & $\begin{array}{l}\oplus \text { Melihat atau menjalankan secara langsung aktivitas } \\
\text { penyelesaian suatu tugas. } \\
\oplus \text { Cocok bagi Anda yang belajar melalui observasi dan juga }\end{array}$ \\
\hline
\end{tabular}




\begin{tabular}{|l|l|}
\hline & \multicolumn{2}{|c|}{ belajar melalui mencoba. } \\
\hline TAHAPAN & \\
\hline Analisa Kebutuhan & \\
\hline Penyusunan Program & \\
\hline
\end{tabular}

\begin{tabular}{|l|l|}
\hline Pelaksanaan Program & \\
\hline Evaluasi Program & \\
\hline
\end{tabular}

Anda telah berhasil menyusun Program Pelatihan dan Program Pengembangan dengan mengisi Lembar Kerja 1.2. di atas. Selanjutnya Anda akan mengetahui cara menyampaikan Program Pelatihan dan Program Pengembangan yang masing-masing cara memiliki maksud dan tujuan tertentu yang juga berdampak pada anggaran Program Pelatihan dan Program Pengembangan. Berikut ini adalah cara-cara menyampaikan Program Pelatihan dan Program Pengembangan:

\begin{tabular}{|c|c|}
\hline & $\begin{array}{l}\oplus \text { Tidak ada resiko dan dampak seperti dalam kondisi nyata. } \\
\text { - Memastikan bahwa contoh sesuai dengan kondisi nyata di pekerjaan, }\end{array}$ \\
\hline $\begin{array}{l}\text { Diskusi } \\
\text { Kelompok }\end{array}$ & $\begin{array}{l}\oplus \text { Bermanfaat untuk bertukar pikiran dan pengalaman yang dimiliki } \\
\text { peserta. } \\
\oplus \text { Orang dewasa umumnya memperoleh ide dari pengalaman orang lain. } \\
\text { - Tidak semua anggota kelompok punya keinginan untuk } \\
\text { berbicara atau membagi pengalaman. } \\
\text { - Apabila diskusi dilakukan pada kelompok yang besar, } \\
\text { akan } \\
\text { memerlukan waktu yang lama. }\end{array}$ \\
\hline $\begin{array}{l}\text { On The Job } \\
\text { Training }\end{array}$ & $\begin{array}{l}\oplus \text { Dilaksanakan pada situasi pekerjaan yang nyata. } \\
\oplus \text { Memperoleh umpan balik secara langsung } \\
\oplus \text { Baik untuk kelompok kecil maupun individual } \\
\text { - Kesulitan mengatur jadwal. } \\
\text { - Mengganggu pekerja yang lain. } \\
\text { - Kehadiran ahli diperlukan untuk memberikan umpan }\end{array}$ \\
\hline
\end{tabular}


balik

langsung.

Berdasarkan program yang telah Anda susun di Lembar Kerja 1.2, silakan tentukan cara penyampaian yang mungkin dilakukan untuk program Anda tersebut. Silakan Anda tuliskan pada Lembar Kerja 1.3 Cara Penyampaian, Anda dapat memilih lebih dari satu cara.

\section{Lembar Kerja 1.3 Cara Penyampaian}

\begin{tabular}{|l|l|}
\hline $\begin{array}{l}\text { Program Pelatihan/ } \\
\text { Program Pengembangan }\end{array}$ & \\
\hline Cara Penyampaian & \\
\hline
\end{tabular}

Anda telah mengetahui cara menyusun Program Pengembangan dan Program Pelatihan dan juga cara penyampaiannya. Kedua hal tersebut berpengaruh terhadap penyusunan Anggaran Program Pengembangan dan Program Pelatihan. Pemilihan cara penyampaian Program Pengembangan dan Program Pelatihan dapat berdampak pada anggaran dan efektifitas dari program. Berikut adalah cara perhitungan sederhana Anggaran Program Pengembangan dan Program Pelatihan bagi usaha Anda :

a. Menetapkan persentase dari biaya operasi.

- Besaran anggaran program pelatihan dan pengembangan sekian persen dari biaya operasi perusahaan.

- Contoh :

Biaya operasi Perusahaan XY sebesar Rp.50.000.000 per tahun. Manajemen Perusahaan $\mathrm{XY}$ telah menetapkan anggaran program pelatihan dan pengembangan $10 \%$ dari biaya operasi, sehingga anggaran program pelatihan pengembangan sebesar Rp.5.000.000 untuk seluruh pekerja. 
- Anggaran tersebut harus dikelola agar dapat memenuhi kebutuhan perusahaan dan juga kebutuhan pengembangan individu.

b. Menetapkan biaya Program Pengembangan dan Program Pelatihan per orang.

- Besaran anggaran ditetapkan per orang.

- Contoh:

Untuk 10 orang pekerja Perusahaan XY menetapkan anggaran untuk masingmasing pekerja sebesar Rp1.000.000 sehingga total menjadi Rp 10.000.000.

- Anggaran tersebut sebagai acuan, dalam pelaksanaannya dapat saja per orang lebih dari anggaran yang telah dihitung namun secara keseluruhan tidak melebihi karena ada pekerja lain yang realisasi anggarannya kurang dari Rp.1.000.000. Sebaiknya penyusunan Anggaran Program Pelatihan dan Pengembangan dilakukan di awal tahun pada saat target usaha Anda ditetapkan sehingga dapat diperoleh gambaran Program Pelatihan dan Pengembangan yang sesuai dengan kebutuhan usaha Anda dalam memenuhi target. Anda dapat melakukan evaluasi Program Pelatihan dan Program Pengembangan dalam beberapa periode waktu :

a. Sesaat setelah pelaksanaan program

- Evaluasi dilakukan untuk mengetahui reaksi pekerja terhadap program yang dijalankan.

- Anda juga dapat mengetahui pemahaman mereka terhadap hal-hal yang mereka pelajari dalam program tersebut.

- Evaluasi dapat dilakukan dengan cara: menanyakan langsung, membuat soal berkaitan dengan program.

b. Beberapa bulan setelah pelaksanaan program

- Evaluasi dilakukan apakah program yang dilaksanakan berdampak pada perubahan cara kerja mereka sehari-hari.

- Evaluasi dapat dilakukan dengan cara: melakukan observasi terhadap aktivitas sehari-hari pekerja, menanyakan langsung kepada pekerja.

c. Di akhir tahun

- Evaluasi dilakukan terhadap rencana pelaksanaan program dan dibandingkan 
dengan pencapaian target perusahaan.

- Evaluasi dapat dilakukan dengan cara: melakukan diskusi dengan pekerja dan meminta pendapat mereka apakah program yang disusun bermanfaat bagi mereka. Selamat !!, Anda telah menyelesaikan modul mengenai Program Pelatihan dan Program Pengembangan yang dapat Anda manfaatkan untuk menyusun program untuk peningkatan kemampuan pekerja di usaha Anda dalam rangka mendukung pencapaian target di perusahaan Anda.

\section{Tips Membuat Packaging / Kemasan.}

Kenapa sih kemasan harus didesain dengan baik?Jawabannya sederhana saja, agar bisa tampak menonjol dan menarik untuk dibeli.

Setiap kali kita pergi ke toko kelontong, pasar, mal atau tempat jual-beli lainnya, kita pasti akan selalu dihadapkan dengan banyak sekali produk yang dikemas dalam boks, botol, tuba atau kemasan lainnya. Kemasan/packaging ini datang dalam beragam bentuk, ukuran dan warna.

Tujuan utama anda mendesain kemasan adalah agar calon konsumen dapat dengan mudah mengenali dan membedakan produk tersebut hanya dengan satu lirikan. Bukan perkara gampang, mengingat produk tersebut akan diletakkan di antara rak-rak yang menjulang, di tengah-tengah lautan produk lain yang sejenis. Namun, tentu saja jangan lupa juga dengan esensi utama kemasan, seperti yang dikatakan Wikipedia:

"Packaging / Kemasan adalah ilmu, seni dan teknik membungkus atau memproteksi produk untuk memudahkan proses distribusi, penyimpanan, penjualan serta penggunaannya. Packaging juga meliputi proses merancang, mengevaluasi dan memproduksi kemasan. Dengan kata lain, packaging dapat dideskripsikan sebagai sistem yang terkoordinasi untuk mempersiapkan produk agar siap dikirim, disimpan, disalurkan, dipasarkan dan dimanfaatkan oleh pengguna akhirnya." 
Jadi, jangan sembarang mendesain kemasan.Faktor perlindungan, pengawetan serta pembungkusan produk juga perlu menjadi bahan pertimbangan. Selain itu, sebaiknya kemasan pun mencantumkan informasi- informasi penting seputar produk tersebut, agar calon konsumen paham akan produk yang akan dibelinya. Tidak perlu harus menuliskan deskripsi produk yang panjang, hanya pastikan saja bahwa konsumen dapat mengenali jenis produk apa yang ada di dalam kemasan tanpa perlu membukanya.

Seringkali, desain kemasan yang menarik dan informatif menjadi perlengkapan pemasaran yang vital.Dan, dalam hal ini, desainer pun turut mempengaruhi keberhasilan - atau malah kegagalan - produk tersebut di pasar.

Tugas yang cukup berat ya? Berikut adalah tips agar rancangan kemasan anda semakin bersinar.

\section{Unik dan kreatif}

Jika anda mau produk (atau kemasan) anda dilirik banyak orang, buatlah kemasan sekreatif mungkin.

Contohlah kemasan sereal sarapan yang sering kali mencantumkan permainan labirin, teka-teki dan lainnya untuk mendorong konsumen untuk membeli produk tersebut. Atau, anda juga bisa berkreasi dengan bentuk kemasan seperti contoh di atas.

\section{Hati-hati memilih font dan warna}

Warna kemasan sebaiknya disesuaikan dengan jenis produknya.Atau, jika perusahaan telah memiliki warna yang khas, boleh juga diaplikasikan pada kemasan. Pastikan bahwa anda menggunakan warna font yang tepat dan kontras.Jangan menggunakan teks oranye mereka beli itu benar. Maka, sudah jadi tugas anda untuk memastikan para konsumen bisa membaca informasi yang tercantum pada kemasan dengan baik. Caranya? Ya, dengan memastikan ukuran dan bentuk font yang digunakan mudah dibaca dong.

Konsumen akan membaca label sebelum membuat keputusan untuk membeli. Beberapa kali, mereka akan membandingkan produk tersebut dengan produk lainnya. Nah, kalau anda mendesain kemasan yang mudah dibaca, dan para konsumen puas dengan informasi yang mereka baca, tentu mereka tidak akan pergi dan mencari produk lain; Mereka akan langsung membelinya. 
Masalahnya, hanya butuh beberapa detik di depan rak di supermarket sebelum konsumen memutuskan akan membeli suatu produk. Mereka tidak punya banyak waktu untuk membaca semua label, makanya jangan buang waktu mereka - dan waktumu - dengan mendesain label yang terlalu kecil dan 'njelimet' untuk dibaca. Ini termasuk salah satu kesalahan yang sering dilakukan para desainer: Mereka membuat label kemasan yang sangat kecil, sehingga sulit bagi konsumen untuk membacanya. Jangan mengulangi kesalahan ini ya.

\section{Manfaatkan gambar}

Masyarakat kita sangat mudah dipengaruhi oleh hal-hal yang dapat dicerna oleh panca indera.Dalam hal kemasan, rangsangan yang paling mudah dicerna adalah rangsangan visual. Karena itu, anda sebaiknya menyertakan gambar/visual dalam desain kemasan anda, entah gambar kartun, foto produk, foto model atau apa pun. Pastikan saja gambarnya beresolusi tinggi, dan akan tampak bagus tidak peduli seberapa besar atau seberapa kecil ukurannya.

\section{Gunakan bahasa yang tepat}

Pilih bahasa yang pas dengan produknya.Konsumen jaman sekarang itu sangat sulit diyakinkan hanya dengan gambar yang indah-indah saja.Mereka butuh informasi - yang berlimpah dan sesuai. produk anda tidak bonafit dan tidak memiliki kontrol kualitas.Maka, berhati-hatilah dengan isu sensitif ini.Anda bisa menggaet kepercayaan dan keyakinan konsumen dengan menggunakan tata bahasa yang benar.

\section{Kenyamanan tak boleh terlupakan}

Yang tak kalah pentingnya, pastikan bahwa kemasan anda mudah dan nyaman digunakan. Ingatlah bahwa kebanyakan orang yang akan menggunakan produk ini orang sibuk Jadi, cobalah buat hidup mereka lebih mudah.Jangan mendesain kemasan yang terlalu besar dan sulit dibawa. Semakin ringkas kemasannya, semakin banyak klien yang akan memilihnya.

Satu poin lagi yang mungkin bisa menjadi bahan pertimbangan: Karena dewasa ini kepedulian masyarakat akan Mother Earth atau Bumi pertiwi sedang tinggi, maka akan baik kalau kemasan yang anda desain terbuat dari bahan-bahan daur ulang atau yang ramah lingkungan. Pasti deh kemasan anda semakin dilirik - setidaknya oleh para pecinta 
lingkungan.

\section{Terlihat kokoh dan tangguh}

\section{Mudah dibuka}

Di sisi lain, kemasan juga tidak boleh terlalu rapat sampai sulit dibuka konsumen. Jadi, anda harus melihat masalah dari dua sisi: Di satu sisi, pastikan kemasan tidak mudah terbuka dan rusak saat diangkut, didistribusikan dan dipasarkan, namun di sisi lain, kemasan mesti cukup mudah dibuka saat sudah sampai ke tangan konsumen. Sekali lagi, pikirkan betapa sibuknya konsumen yang membeli produk anda, dan bayangkan kekesalan mereka saat sudah sampai di rumah, tak sabar ingin menggunakan produk yang baru saja dibelinya, namun kemasannya begitu bandel dan sulit dibuka. Tentu akan sangat mengesalkan bukan? Kalau packaging produk anda memang sulit dibuka, pastikan anda mencantumkan cara-cara membukanya.Kalau bisa, lengkapi juga dengan instruksi bergambar.Bahkan jika kemasannya tergolong mudah dibuka sekalipun, tak salah kok untuk menyertakan instruksi cara membukanya.Siapa tahu saja konsumen membutuhkannya.

\section{Pastikan desain tetap sederhana}

Untuk menarik perhatian, buatlah desain yang sederhana, namun mencolok. Pilih desain yang mudah dikenali oleh konsumen dari segala usia, latar belakang pendidikan dan demografi. Untuk membedakan tipe produk, gunakan warna yang kontras agar konsumen tidak salah memilih. Desain yang sederhana, namun dengan label yang berukuran pas, mudah dibaca, dipenuhi informasi-informasi yang tepat akan lebih menarik perhatian ketimbang desain yang terlalu ramai.

Berikut adalah sebuah perbandingan kue tradisional asal palembang yaitu "Kue ljo" dengan "Kue ljo" lain yang mendapat sentuhan desain kemasan yang baik. Dan dengan hasil sebuah packaging / kemasan yang baik dan fungsional dapat menarik minat beli pelanggan.

1. Kue ljo dan kemasan sederhana

2. Kue ljo dengan sentuhan desain kemasan 


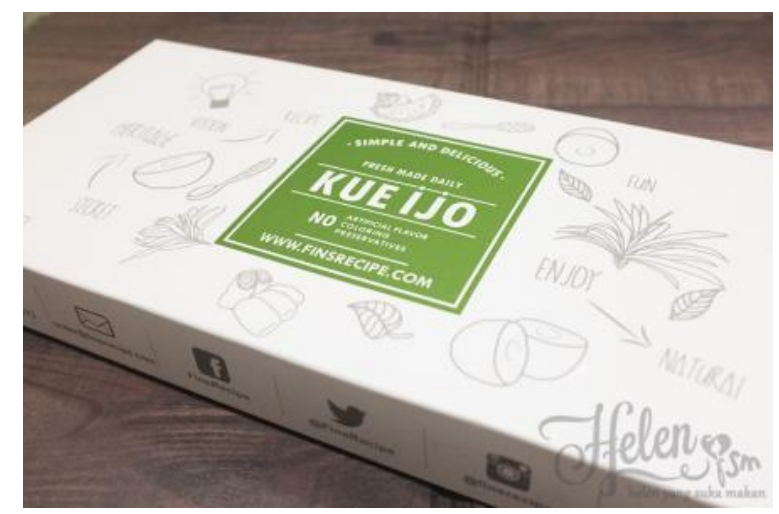

Desain muka, dengan warna putih yg bersih dan hijau menunjukan karakter produk

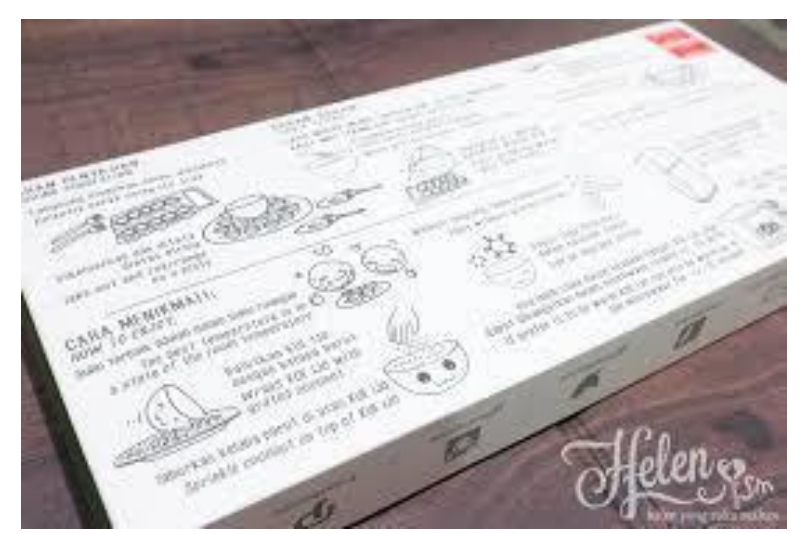

Desain belakang dengan panduan cara makan Desain isi yang rapi, bersih, memastikan kue tidak bergerak, dan diberikan sendok sebagi tambahan.

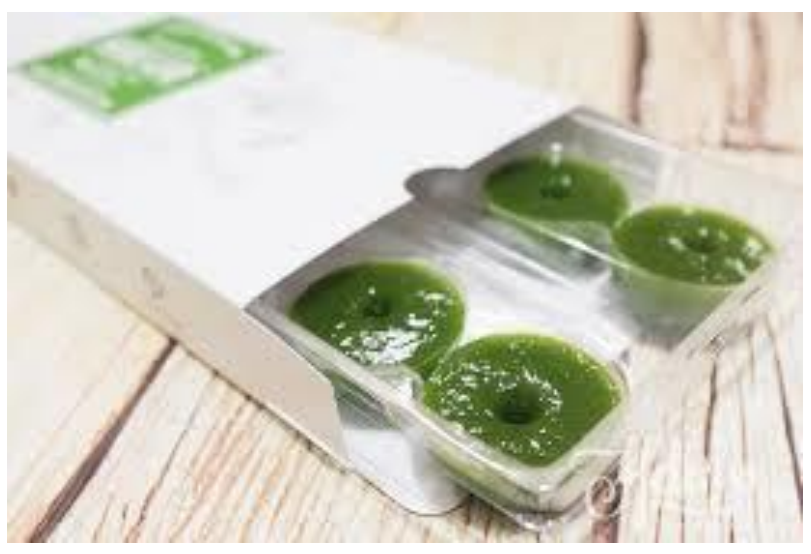

Dengan perbandingan ini akan sangat terlihat bahwa produk yang mendapatkan sentuhan desain kemasan akan menaikan nilai produk tersebut sehingga pembeli rela untuk membayar lebih.

Selain itu dengan suatu desain yang lebih cantik, akan membuka peluang untuk produk itu menjadi produk cinderamata bagi pelanggan. 
242 Kemendagri - sylabus - 2018 